\title{
CORRELAÇÃO ENTRE A ASSIMETRIA CLÍNICA E A ASSIMETRIA RADIOGRÁFICA NA CLASSE II, SUBDIVISÃO
}

\author{
ANGELA RITA PONTES AZEVEDO
}

Dissertação apresentada à

Faculdade de Odontologia de Bauru, Universidade de São Paulo, como parte dos requisitos para obtenção do grau de mestre em Odontologia, área de Ortodontia.

(Edição Revisada) 


\title{
CORRELAÇÃO ENTRE A ASSIMETRIA CLÍNICA E A ASSIMETRIA RADIOGRÁFICA NA CLASSE II, SUBDIVISÃO
}

\author{
ANGELA RITA PONTES AZEVEDO
}

Dissertação apresentada à

Faculdade de Odontologia de Bauru, Universidade de São Paulo, como parte dos requisitos para obtenção do grau de mestre em Odontologia, área de Ortodontia.

(Edição Revisada)

Orientador: Prof. Dr. Guilherme Janson. 


\begin{tabular}{|c|c|}
\hline & AZEVEDO, ANGELA RITA PONTES \\
\hline \multirow[t]{4}{*}{ Az25c } & $\begin{array}{l}\text { Correlação entre a assimetria clínica e a } \\
\text { assimetria radiográfica na Classe II, } \\
\text { subdivisão./ Angela Rita Pontes Azevedo - } \\
\text { Bauru, 2003. }\end{array}$ \\
\hline & 159 págs.:il.; 29,7cm \\
\hline & Dissertação (Mestrado) - Faculdade de \\
\hline & Odontologia de Bauru - USP. \\
\hline
\end{tabular}

Autorizo, exclusivamente para fins acadêmicos e científicos, a reprodução total ou parcial desta dissertação/tese, por processos fotocopiadores e outros meios eletrônicos.

Assinatura do(a) autor(a):

Bauru, 12 de fevereiro de 2003

Parecer de aprovação do Comitê de Ética da FOB-USP.

Data de aprovação: 29 de março de 2001.

OBS.: O parecer encontra-se ao final da seção Apêndice. 


\section{ANGELA RITA PONTES AZEVEDO}

17 de Julho de 1974

Nascimento

Belém - Pa

1992 a 1997

Curso de Graduação em Odontologia pela Universidade Federal do Pará - UFPa.

1997 e 1999

Curso de Aperfeiçoamento em Typodont e Cefalometria Básica - FUNCRAF - Fundação para o Tratamento das Deformidades OânioFaciais - HRAC.

1998 a 1999

Curso de Aperfeiçoamento em Ortodontia

Preventiva e Interceptiva I e II - HRAC Hospital de Reabilitação de Anomalias Craniofaciais - USP (Bauru - SP).

1998 a 1999

Estágio junto ao setor de Ortodontia Preventiva e Corretiva do HRAC - Hospital de Reabilitação de Anomalias Craniofaciais USP.

1999 a 2000

Curso de Especialização em Odontopediatria, pela Faculdade de Odontologia de Bauru USP.

2000 a 2002

Curso de Aperfeiçoamento em Ortodontia Corretiva - ACOPEN (Bauru - SP).

2001 a 2003

Curso de Pós-Graduação Ortodontia, em nível de Mestrado - Faculdade de Odontologia de Bauru - USP. 
Um dia você aprende que...

Depois de algum tempo você aprende a diferença, A sutil diferença entre dar a mão e acorrentar uma alma.

E você aprende que amar não significa apoiar-se,

E que companfia nem sempre significa segurança...

E começa a aceitar suas derrotas

Com a cabeça erguida e olhos adiante,

Com a graça de um adultoe não com a tristeza de uma criança.

E aprende a construir todas as suas estradas no hoje, Porque o terreno do amanfãa é incerto demais para os planos,

E o futuro tem o costume de cair em meio ao vão...

Descobre que se levam anos para se construir confiança

E apenas segundos para destruí-la...

Aprende que verdadeiras amizades

Continuam a crescer mesmo a longas distâncias.

E o que importa não é o que você tem na vida...

Começa a aprender

Que não se deve comparar com os outros,

Mas com o melhor que pode ser...

Aprende que não importa aonde já chegou,

Mas onde está indo...

Aprende que paciência requer muita prática.

Aprende que há mais dos seus pais em você 
Do que você supunha...

Aprende que quando está com raiva tem o direito de estar com raiva,

Mas isso não the dá o direito de ser cruel.

Aprende que nem sempre é suficiente ser perdoado por alguém,

Algumas vezes você tem que aprender a perdoar a si mesmo...

Aprende que não importa

Em quantos pedaços seu coração foi partido,

O mundo não pára para que você o conserte.

Aprende que o tempo não é algo

Que possa voltar para trás...

E você aprende que realmente pode suportar...

Que realmente é forte, e que pode ir muito mais longe

Depois de pensar que não se pode mais.

E que realmente a vida tem valor e que você tem valor diante da vida!

Nossas dádivas são traidoras e nos fazem perder

O bem que poderíamos conquistar,

Se não fosse o medo de tentar.

WILLIAM SHAKESPEARE 


\section{Dedicatória}

\section{A Deus,}

Fonte de fé e sabedoria inesgotável, por me dar força, luz e esperança nos momentos em que se fizeram necessários, pois sem estes, não teria alcançado com sabedoria o fim...

\section{Aos Meus Queridos Pais Ademir e Maria José,}

Pelo exemplo de sensatez, disciplina e integridade, que acreditando nos meus sonhos, não mediram esforços para a sua concretização. Cujo imenso amor e dedicação representam a fortaleza na trilha dos meus objetivos. Vocês sempre foram a minha felicidade e o meu maior orgulho. Obrigada pelo incentivo, confiança e fé que sempre em mim depositaram! Sem vocês eu nunca teria chegado até aqui. 


\section{Às Minhas Queridas Irmãs Camilla e Fabíola,}

Que sempre me dedicaram muita amizade, amor e carinho. Vocês são a minha felicidade. Obrigada, pela confiança, pelas alegrias, pelo apoio que sempre me dedicam e por estarem sempre ao meu lado!

\section{Ao Marcelo,}

Pelo apoio, carinho, amizade e compreensão que me renovaram as forças e me impulsionaram até este ideal. Sua alegria e incentivo, em todos os momentos, foram essenciais para a realização deste sonho.

"O Amor nunca falha, e a vida não falhará enquanto houver Amor. Seja qual for sua crença, ou sua Fé, 6usque primeiro o Amor. Ele está aqui, existindo agora, neste momento. O pior destino que um homem pode ter é viver e morrer sozinho, sem amar e sem ser amado. O poder da vontade não transforma o homem. O tempo não transforma o homem. O Amor transforma."

Henry Drummond.

A todos vocês, com amor, dedico este trabalho. 


\section{Agradecimentos Especiais}

Ao Prof. Dr. Guilherme Janson,

Exemplo de profissionalismo e dedicação, que me possibilitou a aquisição de novos conhecimentos ao longo do curso. Pela orientação criteriosa e confiança em mim depositada para a realização deste trabalho. 


\section{Agradecimentos Especiais}

Ao Prof. Dr. José Fernando Castanha Henriques, Professor

Titular deste Departamento, pelo incentivo profissional, pelas orientações e pela confiança em mim depositada tornando possivel a realização de mais uma etapa de minha vida.

Aos demais professores da disciplina de Ortodontia, Professores Doutores Décio Rodrigues Martins, Renato Rodrigues de Almeida, Marcos Roberto de Freitas e Arnaldo Pinzan, pelos ensinamentos transmitidos durante o curso.

Às minhas avós Iracy e Rita, e ao meu avô Nilo "in memorian", pelo amor e carinho que sempre me dedicaram.

À minha querida Tia Elba e aos meus queridos primos: Hugo, Heloísa e Heloá, por terem sempre acreditado nos meus sonhos e me apoiado durante todos esses anos, sempre me incentivando com muito carinho e alegria. Vocês estarão sempre em meu coração.

Ao meu querido Tio $\mathcal{N i l o , ~ q u e ~ s e m p r e ~ m e ~ d e d i c o u ~ g r a n d e ~}$ carinho e demonstrou grande orgulho a cada etapa por mim conquistada.

A todos os meus familiares, tios, tias, primos e primas pelo carinho e alegria a mim dedicado. 
Ao Prof. Antônio David Corrêa Normando, cujo incentivo e ensinamentos foram muito importantes para que eu desse os primeiros passos na ortodontia.

Ao Prof. Dr. Omar Gabriel da Silva Filho, exemplo de humildade e dedicação, pelo incentivo e apoio profissional, pelos ensinamentos e amizade transmitida durante toda a minha trajetória em Bauru.

Aos meus amigos do mestrado: Leniana, Celso, Rodrigo, Karina, Analu, , Daniele, e Yuka, pelos momentos inesquecíveis, a amizade conquistada e a alegria compartilhada. Vocês deixaram saudade! "... escolha seus aliados e aprenda a lutar acompanhado, porque ninguém vence uma guerra sozinho."

Aos Professores do Curso de Preventiva-FUNCRAF: Aracy, Rita, Aiello, Flávio, Patrícia e Nárima, que sempre estiveram dispostos a ensinar com muita paciência, carinho e dedicação.

Às minhas amigas: Elonice, Patrícia Ionara, Stella, Olívia, Denise, Gabriela, Ana Paula, Heloísa Ono e Janeysa, que me apoiaram nos momentos dificeis e sempre me dedicaram grande amizade, carinho e alegria. "Embora a vida nos leve a caminhos diferentes, a lembrança de vocês permanecerá em meu coração..." 


\section{Agradeço ainda}

À Profa. Dra. Maria Fidela de Lima Navarro, Digníssima Diretora da Faculdade de Odontologia de Bauru, da Universidade de São Paulo.

Ao Prof. Dr. Luiz Fernando Pegoraro, Digníssimo ViceDiretor da Faculdade de Odontologia de Bauru, da Universidade de São Paulo.

Ao Prof. Dr. José Carlos Pereira, Presidente da Comissão de Pós-Graduação da Faculdade de Odontologia de Bauru, da Vniversidade de São Paulo.

Ao Prof. Dr. José Alberto de Souza Freitas, "Tio Gastão", superintendente do Centrinho, por ter cedido as dependências do Hospital de Reabilitação de Anomalias Craniofaciais - HRAC, para a coleta da amostra deste trabalho.

À Profa. Dra. Izabel Maria Marchi de Carvalho, responsável pelo Setor de Radiologia do HRAC, por ter permitido a utilização dos aparelhos de raios-X para a coleta da amostra utilizada neste estudo.

Ao Prof. Dr. José Roberto Lauris, pelas orientações estatísticas. 
Aos professores de Pós-Graduação desta faculdade, pela experiência e ensinamentos transmitidos.

Aos colegas da Pós-graduação pelos momentos de confraternização e alegria.

Aos colegas do mestrado antigo (2000) e do doutorado pelas experiências compartilhadas.

Aos funcionários da disciplina de Ortodontia: Cristina, Sérgio, Vera, Tia Maria, e ao funcionário da ACOPEN: Daniel, pela disponibilidade e amizade em todos os momentos.

A XXXVIII turma de Graduação desta faculdade, que muito contribuiu para o meu enriquecimento profissional.

Aos meus pacientes, indispensáveis à minha formação profissionale ao meu aprendizado.

Aos funcionários da Pós-Graduação, pela atenção e serviços prestados.

Aos funcionários da 6iblioteca, pela atenção dispensada.

À FAPESP, pela concessão da bolsa de estudo que possibilitou a realização deste trabalho.

E a todos que direta ou indiretamente contribuíram para a realização deste trabalho. 


\section{SUMÁRIO}

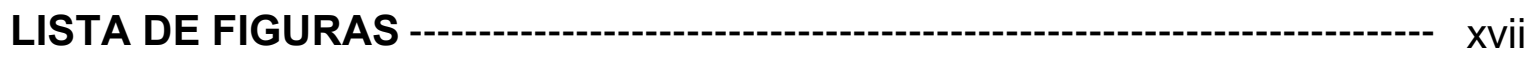

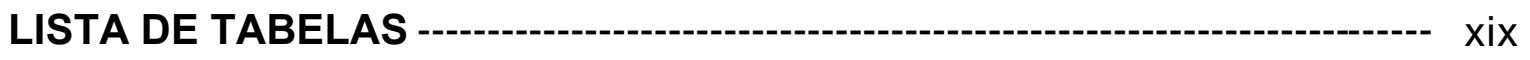

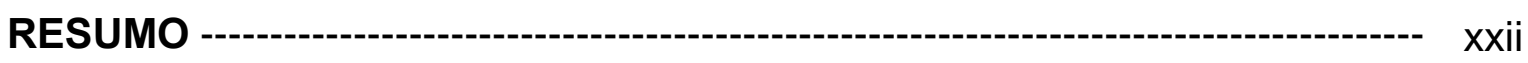

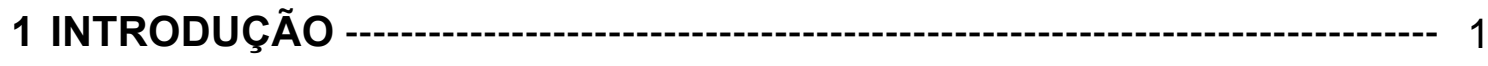

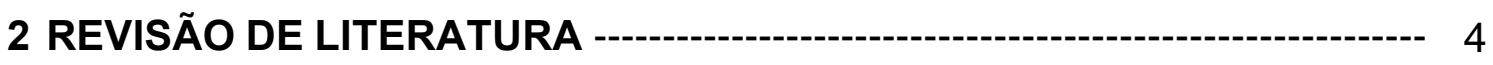

2.1 O crescimento e desenvolvimento craniofacial e

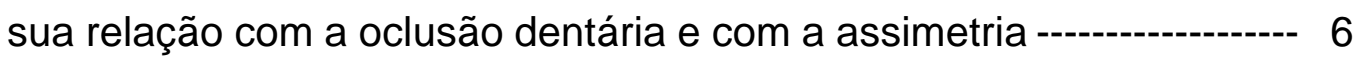

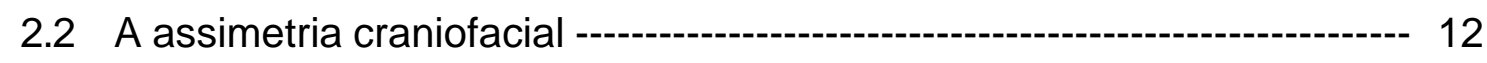

2.2.1 Causas da assimetria craniofacial ----------------------------------- 19

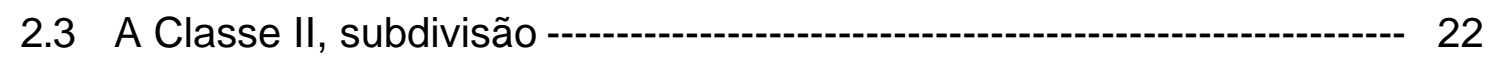

2.4 A assimetria craniofacial e a Classe II, subdivisão ---------------------- 26

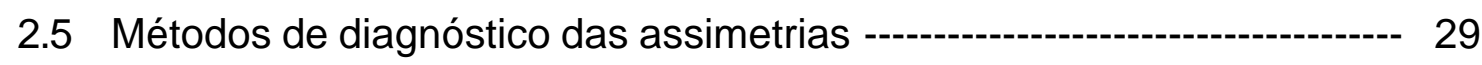

2.5.1 Avaliação clínica, fotográfica e em modelos de estudo ----------- 31

2.5.2 Radiografia ortopantomográfica e cefalograma lateral ------------ 34

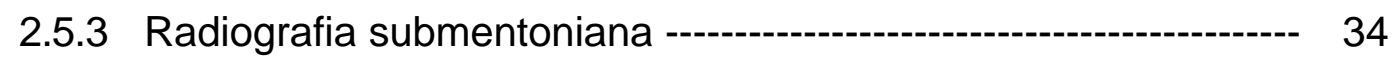

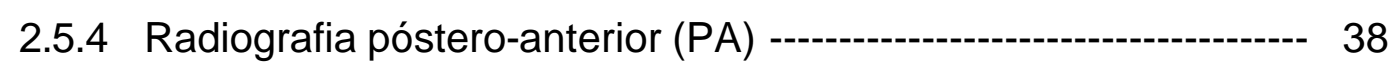

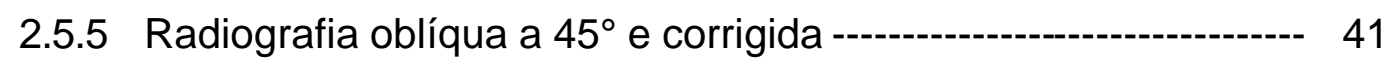

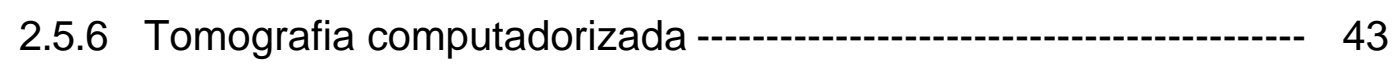

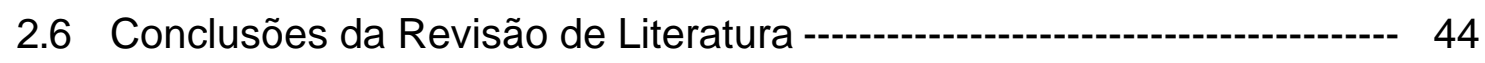

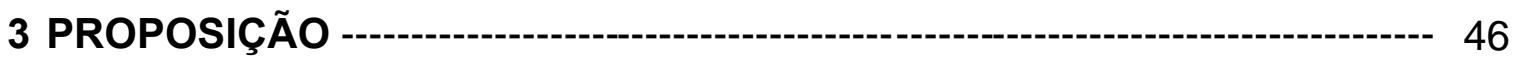

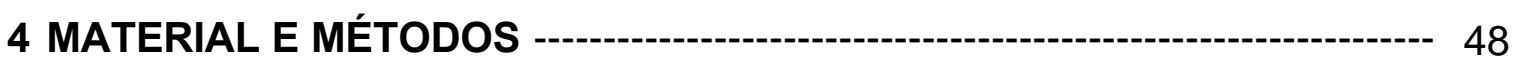

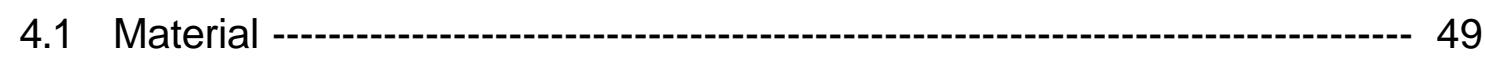

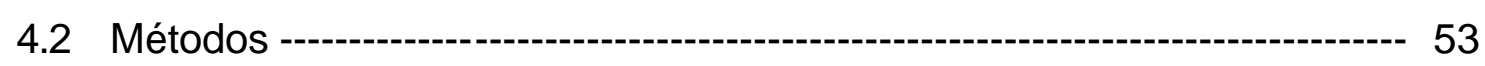

4.2.1 Análise Fotográfica Frontal -------------------------------------------- 53 
4.2.1.1 Pontos de referência ---o- 53

4.2.1.2 Linhas --o--- 54

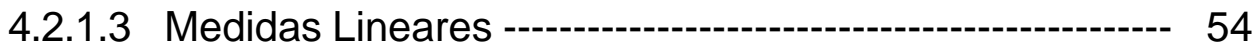

4.2.1.3.1 Proporção entre as medidas bilaterais -------- 55

4.2.2 Radiografia Submentoniana --_- 59

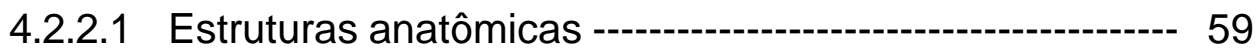

4.2.2.2 Pontos de referência -- 60

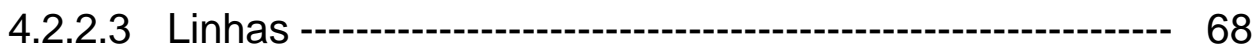

4.2.2.4 Grandezas Cefalométricas ---_---- 70

4.2.2.4.1 Sistema de Coordenadas Mandibulares ----- 71

4.2.2.4.1.1 Ântero-posterior ----o------ 71

4.2.2.4.1.2 Transverso -------------------------- 72

4.2.2.4.2 Sistema de Coordenadas do Assoalho

Craniano 75

4.2.2.4.2.1 Ântero-posterior ----------------- 75

4.2.2.4.2.2 Transverso ------------------------ 76

4.2.2.4.3 Sistema de coordenadas do Complexo

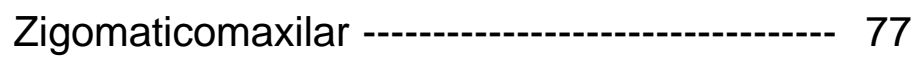

4.2.2.4.3.1 Ântero-posterior ------------------ 77

4.2.2.4.3.2 Transverso ------------------------ 77

4.2.2.4.4 Sistema de Coordenadas Dentárias ---------- 78

4.2.2.4.4.1 Ântero-posterior ----a--a--- 78

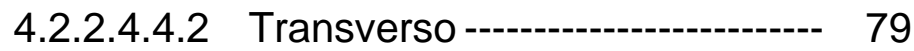

4.2.2.4.5 Medidas angulares entre as abscissas dos sistemas de coordenadas 
4.2.2.4.6 Variáveis Adicionais

4.2.2.4.7 Diferenças entre as medidas bilaterais

4.2.2.4.7.1 Coordenadas Mandibulares ----- 87

4.2.2.4.7.1.1 Ântero-posterior 87

4.2.2.4.7.1.2 Transversal------ 88

4.2.2.4.7.2 Coordenadas do Assoalho

Craniano

4.2.2.4.7.2.1 Ântero-posterior 88

4.2.2.4.7.2.2 Transversal ------ 88

4.2.2.4.7.3 Complexo Zigomaticomaxilar --- 89

4.2.2.4.7.3.1 Ântero-posterior 89

4.2.2.4.7.3.2 Transversal------ 89

4.2.2.4.7.4 Coordenadas Dentárias 89

4.2.2.4.7.4.1 Ântero-posterior 89

4.2.2.4.7.5 Variáveis Adicionais -------------- 89

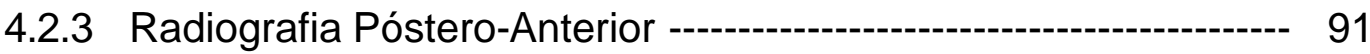

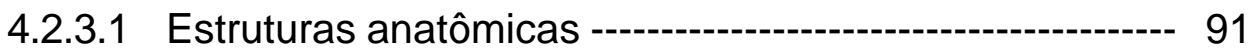

4.2.3.2 Pontos de referência --- 92

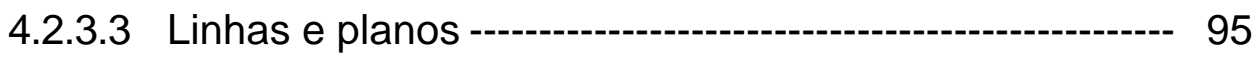

4.2.3.4 Grandezas Cefalométricas ----------------------------------- 96

4.2.3.4.1 Diferenças entre as medidas bilaterais ------- 98

4.2.4 Avaliação da correlação da assimetria clínica e radiográfica no grupo total e nos subgrupos

4.2.5 Comparação entre os grupos ------------------------------------------ 107

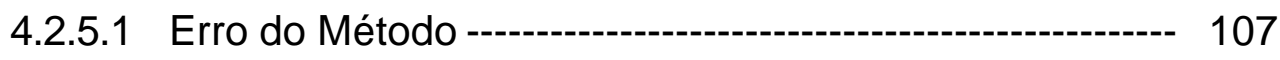




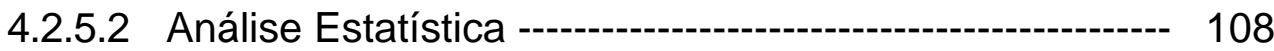

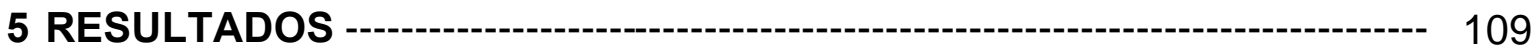

6 DISCUSSÃO --

6.1 Amostra --- 125

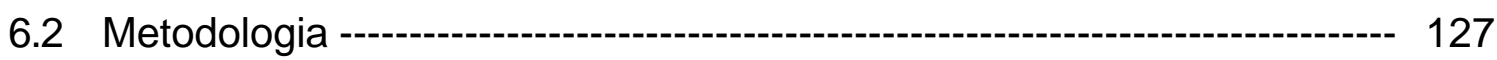

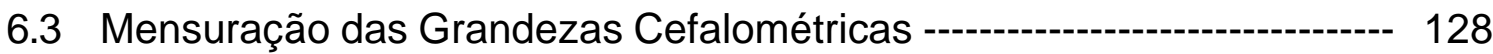

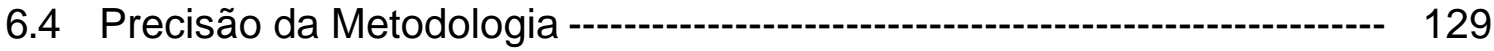

6.5 Interpretação dos resultados obtidos na correlação da fotografia frontal com as radiografias submentoniana e póstero-anterior ----------- 131

6.6 Avaliação das assimetrias entre os grupos de Classe II, subdivisão com assimetria facial aparente e de oclusão normal ------------------------ 133

6.6.1 Sistema de Coordenadas Mandibulares --------------------------- 134

6.6.2 Sistema de Coordenadas do Assoalho Craniano ---------------- 135

6.6.3 Sistema de Coordenadas Zigomaticomaxilares -------------------- 135

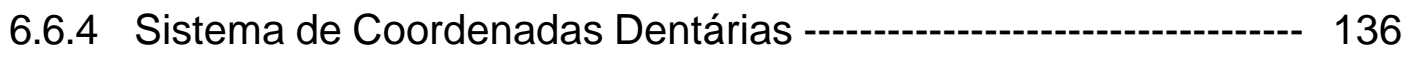

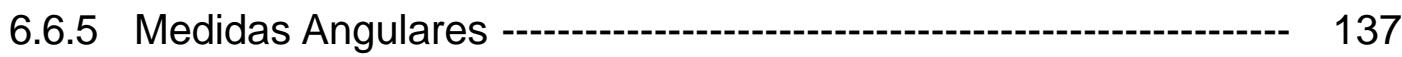

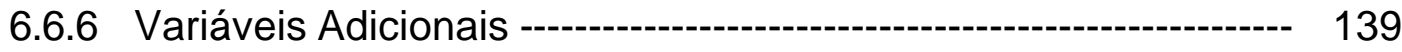

6.6.7 Radiografia Póstero-Anterior --- 139

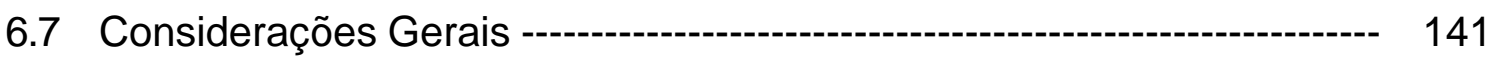

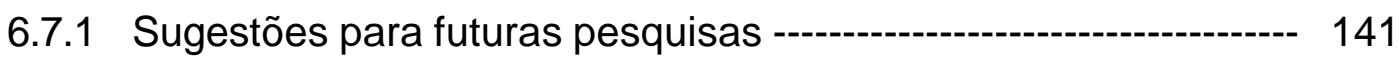

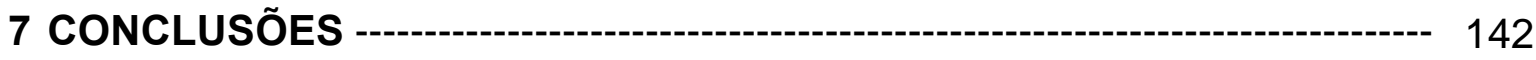

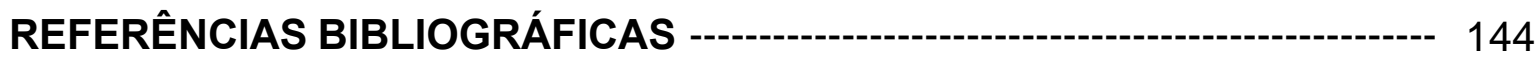

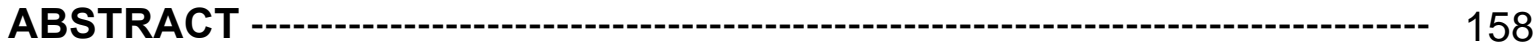

APÊNDICE 


\section{LISTA DE FIGURAS}

FIGURA 1- Caso de Classe II, subdivisão -- 51

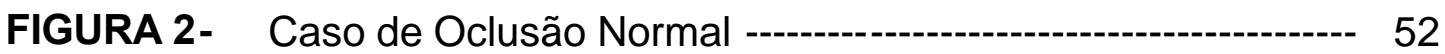

FIGURA 3- Foto Frontal --- 56

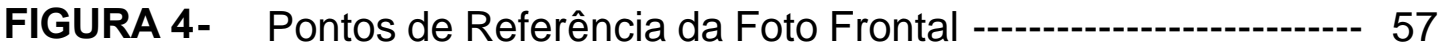

FIGURA 5- Linhas e Medidas Lineares da Foto Frontal ------------------- 58

FIGURA 6- Estruturas Anatômicas da Radiografia Submentoniana ------ 66

FIGURA 7- Pontos de Referência da Radiografia Submentoniana ------- 67

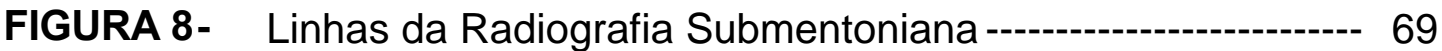

FIGURA 9- Grandezas Cefalométricas da Radiografia Submentoniana - Sistema de Coordenadas Mandibulares - Ânteroposterior

FIGURA 10- Grandezas Cefalométricas da Radiografia Submentoniana - Sistema de Coordenadas Mandibulares - Transverso ----

FIGURA 11- Grandezas Cefalométricas da Radiografia Submentoniana - Sistema de Coordenadas do Assoalho Craniano Ântero-posterior

FIGURA 12- Grandezas Cefalométricas da Radiografia Submentoniana - Sistema de Coordenadas do Assoalho Craniano Transverso

FIGURA 13- Grandezas Cefalométricas da Radiografia Submentoniana - Sistema de Coordenadas do Complexo Zigomaticomaxilar - Ântero-posterior

FIGURA 14- Grandezas Cefalométricas da Radiografia Submentoniana - Sistema de Coordenadas do Complexo Zigomaticomaxilar - Transverso

FIGURA 15- Grandezas Cefalométricas da Radiografia Submentoniana - Sistema de Coordenadas Dentárias - Ântero-posterior e Transverso

FIGURA 16- Grandezas Cefalométricas da Radiografia Submentoniana - Medidas Angulares entre as Abscissas dos Sistemas de Coordenadas 
FIGURA 17- Grandezas Cefalométricas da Radiografia Submentoniana - Variáveis Adicionais 90

FIGURA 18- Estruturas Anatômicas da Radiografia Póstero-Anterior ----- 100

FIGURA 19- Pontos de Referência da Radiografia Póstero-Anterior ------ 101

FIGURA 20- Linhas e Planos da Radiografia Póstero-Anterior ------------ 102

FIGURA 21- Grandezas Angulares da Radiografia Póstero-Anterior ------ 103

FIGURA 22- Grandezas Lineares da Radiografia Póstero-Anterior -------- 104 


\section{LISTA DE TABELAS}

TABELA 1 Médias, desvios-padrão, máximo e mínimo das idades do grupo experimental subdividido de acordo com o tipo de subdivisão e do grupo controle de oclusão normal

TABELA 2 Valores absolutos das médias das medidas das fotografias frontais dos grupos 1 (42 pacientes Classe II, subdivisão), 2 (25 pacientes Classe II, subdivisão, tipo 1) e 3 (8 pacientes Classe II, subdivisão, tipo 2)

TABELA 3 Análise intra-examinador da precisão da metodologia empregada: apresentação dos erros casuais de DAHLBERG ${ }^{27}$, das médias, dos desvios padrão (D.P.) das diferenças e nível de significância estatística dos erros sistemáticos, entre a primeira e a segunda medição das fotografias

Análise intra-examinador da precisão da metodologia empregada: apresentação dos erros casuais de DAHLBERG ${ }^{27}$, das médias, dos desvios padrão (D.P.) das diferenças e nível de significância estatística dos erros sistemáticos ( $p)$, entre a primeira e a segunda medição dos traçados das radiografias

TABELA 4 Radiografia Submentoniana - Sistema de Coordenadas Mandibulares

TABELA 5 Radiografia Submentoniana - Sistema de Coordenadas do Assoalho Craniano

TABELA 6 Radiografia Submentoniana - Sistema de Coordenadas Zigomaticomaxilares

TABELA 7 Radiografia Submentoniana - Sistema de Coordenadas Dentárias

TABELA 8 Radiografia Submentoniana - Medidas Angulares 114

TABELA 9 Radiografia Submentoniana - Variáveis Adicionais 115

TABELA 10 Radiografia Póstero-Anterior 
TABELA 11 Resultado do Teste de Correlação de Pearson entre as medidas da Radiografia Submentoniana - Sistema de Coordenadas Mandibulares e as medidas da Fotografia Frontal para os grupos 1 (42 pacientes Classe II, subdivisão), 2 (25 pacientes Classe II, subdivisão, tipo 1) e 3 (8 pacientes Classe II, subdivisão, tipo 2)

TABELA 12 Resultado do Teste de Correlação de Pearson entre as medidas da Radiografia Submentoniana - Sistema de Coordenadas do Assoalho Craniano e as medidas da Fotografia Frontal para os grupos 1 (42 pacientes Classe II, subdivisão), 2 (25 pacientes Classe II, subdivisão, tipo 1) e 3 (8 pacientes Classe II, subdivisão, tipo 2)

TABELA 13 Resultado do Teste de Correlação de Pearson entre as medidas da Radiografia Submentoniana - Sistema de Coordenadas Zigomaticomaxilares e as medidas da Fotografia Frontal para os grupos 1 (42 pacientes Classe II, subdivisão), 2 (25 pacientes Classe II, subdivisão, tipo 1) e 3 (8 pacientes Classe II, subdivisão, tipo 2)

TABELA 14 Resultado do Teste de Correlação de Pearson entre as medidas da Radiografia Submentoniana - Variáveis Adicionais e as medidas Fotografia Frontal para os grupos 1 (42 pacientes Classe II, subdivisão), 2 (25 pacientes Classe II, subdivisão, tipo 1) e 3 (8 pacientes Classe II, subdivisão, tipo 2)

TABELA 15 Resultado do Teste de Correlação de Pearson entre as medidas da Radiografia Póstero-Anterior e as medidas Fotografia Frontal para os grupos 1 (42 pacientes Classe II, subdivisão), 2 (25 pacientes Classe II, subdivisão, tipo 1) e 3 (8 pacientes Classe II, subdivisão, tipo 2)

Resultados do teste $t$ independente, entre os grupos de oclusão normal e de Classe II, subdivisão com assimetria facial aparente 
TABELA 16 Radiografia Submentoniana - Sistema de Coordenadas Mandibulares

TABELA 17 Radiografia Submentoniana - Sistema de Coordenadas do Assoalho Craniano

TABELA 18 Radiografia Submentonia - Sistema de Coordenadas Zigomaticomaxilares

TABELA 19 Radiografia Submentoniana - Sistema de Coordenadas Dentárias

TABELA 20 Radiografia Submentoniana - Medidas Angulares 122

TABELA 21 Radiografia Submentoniana - Variáveis Adicionais 122

TABELA 22 Radiografia Póstero-Anterior 123 
Resumo 


\section{RESUMO}

O objetivo principal deste estudo foi avaliar a correlação entre a assimetria clínica e a assimetria radiográfica nos pacientes com Classe II, subdivisão. Secundariamente, o grau de assimetria esquelética entre pacientes com este tipo de má oclusão e que apresentavam assimetria facial aparente foram comparados com o grau de assimetria dos indivíduos com oclusão normal. A amostra consistiu de 42 indivíduos com má oclusão de Classe II, subdivisão completa e 30 indivíduos com oclusão normal. A idade média dos indivíduos foi de 15,21 e 22,42 anos no grupo com Classe II, subdivisão, e no grupo com oclusão normal, respectivamente. A assimetria clínica foi avaliada medindo-se a diferença relativa da posição espacial dos pontos do tecido mole entre os lados direito e esquerdo em fotografias frontais. A assimetria radiográfica foi avaliada medindo-se a diferença relativa da posição espacial dos pontos dentários e esqueléticos, entre os lados direito e esquerdo nas dimensões ântero-posterior e transversal nas radiografias submentonianas e póstero-anterior. Posteriormente, o teste de correlação de Pearson foi realizado entre as assimetrias nas fotografias e as assimetrias nas radiografias. $\mathrm{O}$ teste $\mathrm{t}$ independente foi utilizado para comparar as assimetrias radiográficas de 23 indivíduos com Classe II, subdivisão com assimetria facial aparente com indivíduos com oclusão normal. A correlação entre a assimetria clínica e a assimetria radiográfica foi muito suave. Apesar das assimetrias encontradas serem predominantemente dentoalveolares, as más oclusões de Classe II, subdivisão, com assimetria facial aparente demonstram uma ligeira assimetria mandibular radiográfica em relação aos casos de Classe II, subdivisão, de uma forma geral. 
1 Introdução 


\section{INTRODUÇÃO}

Os conceitos atuais vigentes para o diagnóstico e plano de tratamento remetem ao equilíbrio e à harmonia dos traços faciais ${ }^{126}$. 0 tratamento ortodôntico não tenta alterar a característica racial do paciente, mas sim estabelecer harmonia e equilíbrio entre a oclusão e o tecido mole adjacente. A harmonia refere-se a um relacionamento agradável entre a oclusão e o tecido mole ${ }^{52}$.

As más oclusões de Classe II, subdivisão apresentam dificuldades no tratamento ortodôntico devido à relação oclusal assimétrica (Classe II de um lado do arco dentário e Classe I do outro) e a dificuldade em se diagnosticar os fatores responsáveis pela má oclusão. Uma questão freqüentemente levantada na literatura é quanto à origem da assimetria, se esta é predominantemente dentoalveolar, esquelética ou uma combinação de ambas. A subdivisão acomete aproximadamente $50 \%$ das más oclusões de Classe $\mathbb{1}^{3}$, enquanto na distribuição geral das más oclusões a Classe II tem uma incidência de $42 \%{ }^{121}$, por isso a localização e a extensão da assimetria é fundamental. Outra característica amplamente demonstrada na literatura é o fato da Classe II, subdivisão, não apresentar assimetrias esqueléticas em relação à oclusão normal ${ }^{1,55}$. Entretanto, em muitos casos de Classe II, subdivisão podemos perceber ligeiras assimetrias faciais em alguns pacientes.

Embora alguns autores considerem a simetria absoluta da face como uma condição normal do ser humano ${ }^{122,127}$, a maioria dos autores afirma que a face humana caracteriza-se por apresentar pequenas assimetrias, que configuram um estado de normalidade e somente são observadas nas grandes alterações $9,32,36,77,117,130,131$. Em muitos casos esta assimetria facial só pode ser observada se compararmos as partes homólogas da face ${ }^{15,36}$.

THOMPSON $^{131}$, no ano de 1943, em seu estudo sobre a assimetria facial, afirmou que não há uma face verdadeiramente simétrica em qualquer idade, gênero ou raça. Graus suaves de assimetrias faciais, também denominadas de assimetrias "normais", são comuns na população em geral, sem significância estética ou funcional, tornando-se importante quando afetar a estética ou a função do paciente. E embora algumas destas assimetrias sejam 
principalmente encontradas nos tecidos moles, contribuições esqueléticas podem estar presentes.

No ano de 1988, ALAVI; BEGOLE e SCHNEIDER ${ }^{1}$ observaram que a Classe II, subdivisão resulta principalmente de uma assimetria na posição dos molares inferiores, embora não tenham descriminado se a origem do problema seria dentária, esquelética ou uma combinação de ambas. ROSE et al. $^{107}$, no ano de 1994, confirmaram que a Classe II, subdivisão ocorria, geralmente, pela posição mais posterior do molar inferior, no lado da Classe II, do que no lado da Classe I. JANSON ${ }^{55}$, em 1998, concluiu que os componentes mais freqüentes que contribuem para a relação ântero-posterior assimétrica na Classe II, subdivisão, eram dentoalveolares, sendo que a principal diferença entre a má oclusão de Classe II, subdivisão e a oclusão normal consistiu numa posição mais para distal do primeiro molar inferior do lado da Classe II, em uma base óssea $\infty$ m assimetria normal. Uma diferença secundária consistiu na posição mais para mesial do primeiro molar superior, no lado da Classe II. Entretanto, em muitos casos de Classe II, subdivisão é possível se perceber ligeiras assimetrias faciais em alguns pacientes ${ }^{55}$. Portanto, o objetivo principal deste trabalho é investigar se há correlação entre a assimetria clínica e a assimetria radiográfica nesse tipo de má oclusão, e comparar o grau de assimetria esquelética entre indivíduos com Classe II,subdivisão e com assimetria facial aparente com o grau de assimetria dos indivíduos com oclusão normal. 
2 Revisão de Literatura 


\section{REVISÃO DE LITERATURA}

Com o intuito de facilitar a compreensão do assunto a ser estudado, a revisão de literatura será abordada de acordo com os seguintes tópicos:

2.1 O crescimento e o desenvolvimento craniofacial e a sua relação com a oclusão dentária e com a assimetria;

2.2 A assimetria craniofacial;

2.2.1 Causas da assimetria craniofacial;

2.3 A Classe II, subdivisão;

2.4 A assimetria craniofacial e a Classe II, subdivisão;

2.5 Métodos de diagnóstico das assimetrias;

2.5.1 Avaliação clínica, fotográfica e em modelos de estudo;

2.5.2 Radiografia panorâmica e cefalograma lateral;

2.5.3 Radiografia submentoniana;

2.5.4 Radiografia póstero-anterior (PA);

2.5.5 Radiografia oblíqua a $45^{\circ}$ e corrigida;

2.5.6 Tomografia computadorizada.

2.6 Conclusões da Revisão de Literatura. 


\subsection{O CRESCIMENTO E O DESENVOLVIMENTO CRANIOFACIAL E A SUA RELAÇÃO COM A OCLUSÃO DENTÁRIA E COM A ASSIMETRIA}

Alguns pesquisadores ${ }^{18,24,90,142}$ mostraram que a assimetria
craniofacial ocorre freqüentemente na maioria da população, sendo a assimetria uma condição que independe da má oclusão ${ }^{36,67,70}$.

O corpo humano, como de todos os vertebrados, é construído pela reunião de unidades morfológicas de natureza diferente, que se separam à custa de eixos e planos ideais. Antimetria é a construção do corpo humano, que obedece ao plano geral de simetria, que se pode evidenciar na conformação externa do corpo, que é a simetria externa ou simetria de massa; ou no arranjo dos órgãos internos, que é a simetria interna ou simetria de construção. A simetria é mais perfeita nas formas animais simples, e também nas primeiras fases de desenvolvimento individual, dos tipos de construção mais complexa. Portanto o grau de simetria diminui proporcionalmente com a evolução, na filogênese e na ontogênese ${ }^{2}$.

Acreditando estar na mandíbula a principal anormalidade presente nas más oclusões de Classe II, divisão 1, em 1948, os autores NELSON e HIGLEY ${ }^{85}$ restringiram-se ao estudo do comprimento do corpo da mandíbula, em crianças entre 7 e 14 anos, comparando grupos com má oclusão de Classe II, divisão 1 com grupos de oclusão normal e com má oclusão de Classe I. Os autores verificaram uma diminuição do comprimento do osso basal mandibular nos casos de Classe II, divisão 1. No entanto, os valores médios e mínimos encontrados foram muito próximos nos grupos estudados, sugerindo que outros aspectos deveriam estar presentes, contribuindo para a retrusão mandibular.

A assimetria ocorre na maioria dos crânios "normais" com uma correlação estatisticamente significante desta assimetria com a presença de má oclusão severa ${ }^{132}$. Os ossos parietais e o occipital em crânios "normais" freqüentemente são assimétricos. Muitas vezes pode-se observar uma saliência eminente em um lado do crânio causada por uma força constante. Em muitos destes casos observa-se também uma má oclusão severa. Isto sugere que a assimetria observada no crânio, particularmente no osso occipital, pode ser responsável pela transmissão de forças assimétricas. Estas forças podem 
produzir ou são produzidas por uma má oclusão. Obviamente, outros fatores além da má oclusão podem estar relacionados à assimetria das estruturas do crânio.

A deformação occipital usualmente resulta em um menor tamanho da base do crânio no lado mais deformado, posicionando a cavidade glenóide mais anteriormente deste mesmo lado. Deste modo, a linha média facial não desenvolve uma assimetria de maneira análoga à base do crânio, porque o crescimento maxilomandibular é inferior no lado deformado. Este efeito referese a uma assimetria compensatória dos maxilares, diferentemente da assimetria displásica que promove uma hipo ou hiperplasia unilateral do côndilo mandibular ${ }^{18}$.

Diversas variáveis existentes na face foram demonstradas por ENLOW, KURODA e LEWIS ${ }^{30}$, em 1971. Estes autores afirmaram que uma alteração em alguma porção do complexo craniofacial produz uma alteração igual em outra parte e, algumas vezes, em sentido contrário. Devido à habilidade intrínseca individual para compensar alterações de crescimento regionais, uma alteração relevante em uma parte anatômica não impede necessariamente o desenvolvimento de proporções faciais harmoniosas.

MONGINI $^{78}$, em 1972, estudou macroscópica e microscopicamente a remodelação condilar em 100 indivíduos de ambos os sexos, entre as idades de 18 e 67 anos, após a morte. Seis cortes no sentido ântero-posterior (3 de cada lado) foram realizados em cada crânio, incluídos em metilmetacrilato e examinados microscopicamente. Relacionourse a remodelação com a idade e o edentulismo. Os resultados levaram o autor a concluir que: a remodelacão é particularmente freqüente nas regiões posterior e anterior do côndilo e é responsável por certas formas características; a incidência de remodelação aumenta rapidamente entre as idades de 18 e 25 anos, sendo que após essa idade não apresenta nenhuma influência; a remodelação torna-se significantemente mais freqüente à medida que o edentulismo aumenta; as trabéculas do tecido esponjoso tendem a se dispor, em ângulos retos, à superfície óssea, em locais onde a remodelação é mais ativa. Os resultados indicam que a remodelação do côndilo é primariamente a expressão de adaptação da estrutura óssea aos estresses mecânicos provenientes da atividade funcional. 
A anatomia craniofacial normal pode demonstrar graus variados de assimetria, desde a assimetria subclínica, compatível com a oclusão normal, até as assimetrias acentuadas, resultantes de causas traumáticas, patológicas ou do desenvolvimento ${ }^{25}$. A deformação do crânio pode ocorrer no útero, durante o nascimento ou na infância. Além disso, uma forma de deformação craniofacial, a plagiocefalia, pode acontecer algumas semanas após o nascimento em bebês que eram simétricos ao nascer. A associação entre a assimetria facial, a assimetria da base craniana, a plagiocefalia e a assimetria do esqueleto axial tem sido intensamente investigada. A plagiocefalia pode ser revertida espontaneamente para uma situação mais simétrica, enquanto que a base do crânio pode sofrer uma deformação permanente que pode posteriormente se relacionar com uma assimetria facial clínica. Provavelmente todas as estruturas craniofaciais demonstram algum grau de assimetria, sendo geralmente subclínica e compatível com a oclusão normal.

Com o propósito de avaliar a influência da oclusão na posição condilar através da tomografia da ATM, PULLINGER et al. ${ }^{101}$, em 1987, avaliaram 44 adultos jovens, sem história de tratamento ortodôntico ou desgaste oclusal e sem sintomatologia de desordem da ATM, em diferentes tipos de má oclusão. Foram tomadas tomografias laterais das ATMs dos lados direito e esquerdo. Foi concluído que: a má oclusão de Classe II foi mais associada com a excentricidade da posição condilar do que a Classe I, e a posição condilar na Classe II, divisão 1 estava mais freqüentemente anteriorizada.

A função anormal do músculo cervical pode causar uma postura anormal da cabeça, afetando desfavoravelmente o desenvolvimento e a morfologia da coluna cervical e do esqueleto maxilofacial, o que induz à assimetria facial e oclusal ${ }^{61,124}$. A atividade anormal do músculo cervical e dos músculos mastigatórios pode ocasionar anormalidades morfológicas da mandíbula e da articulação temporomandibular (ATM) e contribuir para o desenvolvimento de desordens temporomandibulares ${ }^{61}$.

O contorno da eminência articular mostra grande variação individual, podendo relacionar-se com a morfologia da face. A morfologia mandibular correlaciona-se com a inclinação da superfície aticular da fossa glenóide, de modo que uma mandíbula retangular decorre de uma fossa 
profunda, enquanto que uma mandíbula triangular provém de uma fossa rasa. A morfologia da fossa glenóide constitui-se num elemento essencial do crescimento mandibular, havendo um íntimo relacionamento entre sua posição e algumas discrepâncias esqueléticas e as más oclusões ${ }^{59}$. A fossa glenóide, nas más oclusões de Classe I, localiza-se mais anteriormente do que na Classe II, enquanto que na Classe III, relaciona-se mais anteriormente em relação ao crânio.

Em pacientes em crescimento, a assimetria crânio-mandibular com um desvio transversal da mandíbula e do mento, sem origem genética ou congênita e sem história de trauma, infecção ou tumor, é possível o deslocamento mandibular como conseqüência de alterações oclusais. Se o deslocamento mandibular não for detectado e tratado precocemente, uma assimetria mandibular adaptativa pode se desenvolver. Contudo, o deslocamento mandibular não pode ser todo ou em parte causado pela disfunção crânio-mandibular ${ }^{114}$.

Investigando a diferença entre os lados direito e esquerdo da face, em 1991, PONYI; SZABÓ e NYILASP ${ }^{99}$ realizaram 18 medidas mandibulares em crânios europeus, de ambos os gêneros. A assimetria dos lados esquerdo e direito foi encontrada entre as dimensões mandibulares medidas individualmente em $41,4 \%$ dos crânios masculinos e $40,4 \%$ dos crânios femininos.

Um estudo longitudinal foi realizado por MELNIK ${ }^{74}$, em 1992, para avaliar as mudanças na simetria mandibular de acordo com a idade e com 0 gênero. Foi avaliada através da radiografia oblíqua a $45^{\circ}$ a assimetria do tecido ósseo entre os lados direito e esquerdo da altura da mandíbula e o ângulo goníaco direito e esquerdo. A assimetria foi comum em todas as idades, sendo que a altura mandibular no gênero masculino foi consideravelmente maior do que no feminino, com exceção aos 12 anos de idade, que não houve diferença entre os gêneros. Além disso, os pacientes do gênero masculino tendem a ser mais assimétricos em idades mais precoces, porém a partir dos 14 anos não há diferença estatisticamente significante. O lado esquerdo da mandíbula foi maior do que o direito, em média, no gênero nas idades de 6 e 9 anos;contudo, na idade de 16 anos, o lado direito foi maior. Para o gênero feminino houve uma tendência similar, além disso, essa diferença ocorreu mais precocemente. Em 
média, o lado direito foi significantemente maior aos 12 anos de idade. A probabilidade de melhora da assimetria foi entre os 6 e 16 anos de idade. Não houve diferença estatisticamente significante entre os ângulos goníacos direito e esquerdo para ambos os gêneros e para todas as idades estudadas, com exceção do gênero masculino aos 16 anos de idade, onde foi observada uma diferença de $0,9^{\circ}$.

O crescimento assimétrico na região mandibulofacial ocorre freqüentemente, e poucas pesquisas têm sido realizadas para avaliar o mecanismo básico ou a associação entre o processo de desenvolvimento assimétrico nesta região. A importância do estudo dessa associação é óbvia, para uma melhor atenção dos problemas associados com uma oclusão desfavorável, por exemplo: a má oclusão unilateral ${ }^{97}$.

Outra questão levantada é se os pacientes com hipodontia apresentam alteração da estrutura craniofacial e do padrão de crescimento. A maior freqüência da prevalência de hipodontia é encontrada no segundo prémolar inferior, no segundo pré-molar superior, e nos incisivos laterais superiores nesta ordem. As alterações que causam o aumento do número de dentes permanentes ausentes são limitadas pelos parâmetros dentários e pelo tecido mole. Em pacientes com hipodontia severa (dez dentes ausentes ou mais), os incisivos superiores e inferiores estão retroinclinados, reduzindo a protrusão dos lábios. A protrusão da maxila é reduzida e ocorre provavelmente como conseqüência do menor suporte posterior, a mandíbula rota anteriormente ${ }^{87}$.

Em 1995, O'BYRN et al. ${ }^{86}$ conduziram uma pesquisa objetivando determinar se a simetria mandibular em adultos com mordida cruzada posterior unilateral era diferente daquela de adultos com más oclusões de Classe I, não tratadas. Trinta adultos, acima de 18 anos, com mordida cruzada posterior unilateral foram comparados com 30 adultos com más oclusões de Classe I. Radiografias submentonianas foram obtidas para se avaliar as simetrias esquelética e dentária, enquanto as tomografias horizontais corrigidas serviram para avaliar a posição condilar dentro da fossa glenóide. Em relação ao sistema de coordenadas mandibulares, o primeiro molar inferior, do lado da mordida cruzada, apresentava-se mais lateral e distalmente, em comparação com o do lado oposto. Esqueleticamente, a mandíbula não demonstrou 
assimetria. A mandíbula apresentourse rotacionada em relação ao assoalho craniano, de forma que o côndilo do lado da mordida cruzada estava posicionado posteriormente em relação ao lado oposto. Concluiurse que havia uma posição posterior relativa da fossa glenóide, uma vez que não se observou nenhuma assimetria mandibular esquelética ou deslocamento condilar dentro da fossa, como evidenciado nas tomografias corrigidas no grupo com mordida cruzada, quando comparadas com as do grupo de Classe I. Os autores questionaram se seria correto corrigir mordidas cruzadas posteriores unilaterais em adultos apenas ortodonticamente, com a movimentação dentária, considerando-se que a remodelação óssea da fossa glenóide já possa ter ocorrido. Concluíram que as adaptações tanto na posição mandibular, relativas ao sistema de coordenadas do assoalho craniano, como na dentição, em relação ao sistema de coordenadas mandibulares, existem em adultos com mordida cruzada posterior não tratada. Com a correção do problema oclusal, há um aumento da possibilidade destas alterações ocorrerem dentro da fossa glenóide. As mudanças suaves da posição condilar relacionam-se com a capacidade adaptativa de alguns pacientes em tolerar o desconforto e a dor.

As más posições dentárias, muitas vezes, encontram-se associadas a irregularidades no posicionamento espacial da maxila e da mandíbula e destes ossos com a base do crânio. O crescimento e o desenvolvimento craniofacial dentro dos padrões normais são essenciais para uma harmoniosa estética facial ${ }^{35}$.

A maioria dos casos de mordida cruzada posterior ocorre quando a discrepância oclusal resulta da insuficiência da largura do arco superior em relação ao inferior. Em jovens, a mordida cruzada posterior unilateral usualmente acompanha o desvio funcional lateral mandibular do contato inicial até a máxima intercuspidação, resultando em uma intercuspidação deficiente e interferências oclusais. Este desvio funcional ocorre transversalmente, com a linha média dentária inferior desviada em direção ao lado cruzado em relação à linha média superior, bem como no sentido ântero-posterior, resultando geralmente numa má oclusão de Classe II, subdivisão no lado da mordida cruzada. LAM; SADOWSKY e OMERZA ${ }^{64}$, em 1999, verificaram a diferença entre a posição condilar em jovens com mordida cruzada funcional e jovens com má oclusão de Classe I, sem mordida cruzada. Além disso, avaliaram se 
havia uma alteração na posição condilar, após a correção da mordida cruzada pela expansão palatina. Trinta e um jovens entre 6 a 14 anos, com mordida cruzada posterior unilateral foram comparados com uma amostra controle de 31 jovens entre 9 e 14 anos, exibindo Classe I de Angle, sem mordida cruzada. Radiografias submentonianas foram obtidas, antes do tratamento, para se estudar a assimetria esquelética, dentária e posicional com referência aos sistemas de coordenadas mandibulares e do assoalho craniano. Adicionalmente, os espaços condilares anterior, superior e posterior foram medidos para se determinar as diferenças entre os grupos com o uso de tomografias horizontais corrigidas da ATM, pré e pós-tratamento, além dos modelos de gesso. Finalmente, a distância entre a cúspide mesiovestibular do primeiro molar permanente à fossa vestibular do primeiro molar inferior foram medidas em ambos os grupos, antes do tratamento. Pela análise estatística, verificourse que a mandíbula do grupo com mordida cruzada posterior unilateral funcional exibia uma assimetria nas dimensões ântero-posterior e transversa quando comparadas com o grupo de Classe I, sem mordida cruzada. Estas assimetrias provavelmente resultaram de um desvio funcional mandibular presente em todos os pacientes do grupo com mordida cruzada. Este desvio foi manifestado pela Classe II, subdivisâo no lado da mordida cruzada como indicado na análise dos modelos. Os resultados das tomografias horizontais corrigidas não evidenciaram qualquer diferença na relação côndilofossa intra e intergrupos, pré e pós-tratamento.

\subsection{A ASSIMETRIA CRANIOFACIAL}

O conceito clássico de simetria facial ficou expressivamente difundido no século XV, na arte de Leonardo da Vinci e Albrecht Durer, que consideravam a simetria bilateral da face como uma característica morfológica normal ${ }^{69,89}$. Em seus trabalhos, a harmonia e o equilíbrio facial eram obtidos com o auxílio de uma linha vertical dividindo a face ao meio, passando pelo centro do nariz, dos lábios e do mento. As pupilas deveriam permanecer eqüidistantes a esta linha e formar um plano interpupilar perpendicular à mesma ${ }^{69}$. Entretanto, a assimetria na região craniofacial foi observada pela 
primeira vez, pelo artista Hasse ${ }^{48}$, em 1887, que em suas investigações visualizou pequenas assimetrias nas esculturas gregas, após a descoberta do anatomista alemão Henke de que a clássica escultura de Vênus de Milo não era simétrica. Hasse ${ }^{48}$, então, examinou a simetria da Vênus de Milo e das faces de inúmeros indivíduos e encontrou que a assimetria facial é um fenômeno comum.

A assimetria funcional e estrutural apresenta-se como uma condição inerente ao corpo humano, estando presente em todos os estágios da evolução $^{77}$.

Em estudos da assimetria do crânio ${ }^{90,142,143}$ foram encontrados que: o osso malar, o occipital e o esfenóide são mais largos no lado esquerdo do que no direito. Enquanto que os ossos frontal, temporais e parietais mostraram o oposto. Outra diferença significante entre os dois lados do crânio foi no comprimento interno, onde o lado direito apresentou-se maior do que o esquerdo.

No estudo da assimetria facial, deve ser reconhecido que não há uma face verdadeiramente simétrica em qualquer idade, gênero ou raça ${ }^{131}$. Graus suaves de assimetria facial são comuns na população em geral, sem significância estética ou funcional. A assimetria torna-se importante quando afeta a estética ou a função do paciente. As assimetrias pequenas não são evidentes, mas as assimetrias moderadas e acentuadas são óbvias.

A assimetria é uma das limitações ortodônticas inerentes ao tecido biológico do complexo dentofacial, que afetam o progresso do tratamento ortodôntico ${ }^{36}$. Os fatores responsáveis pela assimetria no complexo dentofacial não estão confinados aos dentes ou ao processo dveolar. Eles podem ser encontrados em várias partes dos componentes faciais e nas estruturas ao redor dos dentes. Esta assimetria pode ser uni ou bilateral e pode ocorrer nos sentidos: ântero-posterior, súpero-inferior e médio-lateral. A assimetria facial é um fenômeno natural e pode ser detectada comparando-se as partes homólogas da face ${ }^{15,36}$ e também pode ocorrer em pacientes com a oclusão normal. A assimetria dentária pode estar presente sem uma assimetria facial aparente, e as duas assimetrias podem estar presentes concomitantemente no mesmo paciente. 
A assimetria facial ocorre devido a uma assimetria de desenvolvimento do cérebro por razões funcionais ou devido a um hábito muscular assimétrico, como a mastigação unilateral ${ }^{20}$.

Existem quatro tipos de assimetrias dentofaciais que seriam resultantes de diferenças ântero-posteriores unilaterais, diferenças de altura (desarmonia vertical); diferenças laterais horizontais (deslocamentos laterais) e rotações do complexo maxilar ou do ramo mandibular, associadas ou não às variações de tamanho unilaterais. Estas alterações assimétricas atuam afetando o tamanho, a forma e a posição das duas hemifaces direita e esquerda ${ }^{24}$.

As mensurações do esqueleto craniofacial em humanos, em crânios ou em radiografias cefalométricas costumam ser comumente utilizadas no estudo do crescimento e desenvolvimento facial, das bases apicais e dos arcos dentários. Analisando a assimetria facial, comparando-se os lados direito e esquerdo, por meio de radiografias póstero-anteriores, VIG e $\mathrm{HEWITT}^{134}$, em 1975, selecionaram 63 jovens, que não poderiam apresentar nenhum grau de assimetria e nem desarranjos dentários. A faixa etária desta amostra variou entre 9 a 18 anos, com idade média de 14 anos, sendo que 20 jovens eram do gênero masculino e 43 do gênero feminino. Após a realização dos traçados cefalométricos, foi concluído que as regiões da base do crânio e da maxila exibiam uma assimetria predominantemente maior do lado esquerdo, enquanto a mandíbula e as regiões dentoalveolares apresentavam um maior grau de simetria.

A assimetria da face pode estar presente mesmo quando os dentes apresentam um excelente contato oclusal, máxima intercuspidação e linhas médias dentárias superiores e inferiores coincidentes. Além disso, as estruturas da face são significantemente maiores no lado direito do que no lado esquerdo e uma das possíveis causas para a produção da assimetria relaciona-se ao hábito de mastigação unilateral. Como as forças mastigatórias são transmitidas aos dentes para os ossos do crânio e da face, foi observado que a maioria dos jovens mastigava mais do lado direito do que do lado esquerdo, constituindo-se num dos possíveis fatores responsáveis pelo lado direito ser maior que o esquerdo. As faces simétricas e harmoniosas podem 
exibir uma assimetria esquelética, porém os tecidos moles minimizam esta assimetria $^{117}$.

CHEBIB e CHAMMA $^{23}$, em 1981, avaliando a assimetria craniofacial de 64 adultos leucodermas de ambos os gêneros por meio da radiografia póstero-anterior, verificaram que a assimetria era menos freqüente na região mediana do que nas laterais e nenhuma diferença significante foi encontrada em relação ao gênero. As estruturas da região dentoalveolar mediana da maxila, a porção inferior do nariz e o mento mostraram grandes desvios estatísticos dentre todas as estruturas analisadas. Uma significante assimetria horizontal do lado esquerdo estava presente nas estruturas ósseas, com comprometimento muscular associado: temporal (músculo temporal), côndilo (pterigoideo lateral), maxila (bucinador), zigoma (músculos zigomáticos), osso mastoideo (esternocleidomastoideo) e região goníaca (masseter e pterigóideo medial). Desta forma, foi concluído que existe uma diferença entre as estruturas craniofaciais dos lados esquerdo e direito, sendo que o lado esquerdo apresenta uma maior assimetria horizontal e menor assimetria vertical, apesar destes dados há necessidade de mais pesquisas para sua confirmação.

Utilizando-se radiografias póstero-anteriores, PECK, PECK e KATAJA ${ }^{91}$, em 1991, avaliaram a intensidade e a variabilidade morfológica da assimetria craniofacial subclínica. A determinação da assimetria esquelética foi realizada por meio de três medidas bilaterais esqueléticas: a órbita láterosuperior, o zygoma e o gônio. A diferença entre os lados esquerdo e direito da hemiface foi quantificada em milímetros para que a largura total entre os pontos bilaterais fosse calculada. A órbita látero-superior demonstrou a menor assimetria e a menor variabilidade das três dimensões avaliadas, enquanto que a distância vertical entre o zygoma e o gônio revelou a mais forte diferença assimétrica na amostra. Já que estas duas últimas medidas relacionam-se com a oclusão dentária, concluíram que a posição dos dentes pode determinar um desenvolvimento significante da assimetria. Testes adicionais para determinar a dominância esquerda-direita dos dados também foram realizados. Os resultados evelaram que houve uma ligeira dominância para o lado direito, embora não tenha sido estatisticamente significante. Foi concluído que o complexo craniofacial exibe uma menor assimetria e uma maior estabilidade 
dimensional à medida que se aproxima do crânio, validando o uso do ponto cefalométrico orbital latero-superior como ponto de referência craniano estável no cefalograma frontal.

Mais especificamente, a assimetria mandibular, em observações clínicas e radiográficas, resulta em um crescimento acelerado do côndilo mandibular de um lado ou o decréscimo do crescimento do lado oposto ${ }^{129}$. A assimetria mandibular geralmente relaciona-se com uma hiperplasia condilar unilateral associada a um crescimento acelerado. As conseqüências das assimetrias mandibulares poderiam ser a mordida aberta, o desvio da linha média mandibular em direção contrária ao maior lado, a inclinação do plano oclusal e a mordida cruzada do lado mais curto ${ }^{123,129}$. As alterações faciais mais comuns são o desvio do mento, em sentido contrário ao lado mais longo ou proeminência ou achatamento da região goníaca. O ângulo goníaco geralmente se encontra mais agudo no lado mais comprido ${ }^{129}$. A limitação do movimento e a inclinação do plano oclusal também podem ser observadas ${ }^{123}$.

Estudando a assimetria na forma e localização da articulação temporomandibular e sua relação com a assimetria mandibulofacial, em 1992, PIRTTINIEMI e KANTOMAA ${ }^{95}$, analisaram 40 crânios adultos, de ambos os gêneros, sem defeitos estruturais morfológicos, representando um grupo racial uniforme do século XIX, pertencente ao Departamento de Anatomia, da Universidade de Helsinki, na Finlândia. Foram utilizadas radiografias submentonianas, laterais e póstero-anteriores cuja configuração da fossa era claramente definida. Os resultados demonstraram uma assimetria temporomandibular direcional generalizada. A fossa glenóide do lado direito estava mais posicionada lateral e posteriormente do que a esquerda, quando analisada na visão axial. A mandíbula estava geralmente mais comprida no lado esquerdo do que do lado direito, na visão frontal. A assimetria temporomandibular encontrada relacionava-se com as características da base do crânio e as diferenças entre os lados direito e esquerdo do comprimento mandibular. A linha média dentária inferior estava mais desviada para o lado direito do que para o esquerdo pela visão frontal, sugerindo uma tendência a uma oclusão normal, do lado direito e um comprimento mandibular maior para o lado esquerdo. Este aspecto relaciona-se com a assimetria condilar, uma vez que a superfície articular é mais perpendicular no lado direito do que no 
esquerdo. Desta forma, a direção de crescimento condilar no lado direito favorece uma tendência pós-normal na oclusão. A razão básica para 0 relacionamento assimétrico direcional vinculourse com a interação recíproca entre o desenvolvimento assimétrico da base do crânio e a influência da função direcional.

A assimetria é comumente encontrada no esqueleto crânio-facial humano, ocorrendo entre os hemisférios do cérebro nos fetos e nos recémnascidos, e mais evidentemente nos adultos ${ }^{97}$.

Avaliando a prevalência de assimetria facial, em 1.490 pacientes apresentando deformidades dentofaciais na Universidade da Carolina do Norte, SEVERT e PROFFIT ${ }^{116}$, em 1997, observaram que a assimetria facial clinicamente aparente estava presente em 495 pacientes, totalizando 34\% da amostra. Quando presente, a assimetria facial afetava a porção superior da face em apenas 23 casos (5\%), o terço médio, primeiramente o nariz, em 178 casos (36\%) e o mento em 365 casos (74\%). O plano oclusal apresentava-se inclinado, indicando uma assimetria vertical, em 201 casos (41\%). Os pacientes com má oclusão de Classe II, devido ou não à deficiência mandibular, apresentaram $28 \%$ de prevalência de assimetria, enquanto os pacientes com más oclusões de Classe I e III apresentaram 40\% de prevalência, tornando-se significantemente mais elevado do que aqueles com má oclusão de Classe II. Quando o mento se apresentava desviado transversalmente, houve $80 \%$ de chance que este desvio fosse para o lado esquerdo. Somente nos pacientes com a face longa, houve um deslocamento igual do mento tanto para o lado esquerdo como para o direito. Nos outros grupos, a prevalência do desvio do mento para o lado esquerdo alcançou 90\%. Estes resultados são significantes para os clínicos porque a assimetria pode ser identificada e planejada antes do inicio do tratamento.

A assimetria normal na região do esqueleto craniofacial pode ser direcional ou flutuante ${ }^{94}$. A direcional pode ser encontrada em três dimensões: ântero-posterior; craniocaudal e assimetrias nas dimensões direita e esquerda. Quando ocorre por diferença bilateral, sua justificativa torna-se complexa, apesar de se manifestar freqüentemente. Em geral, quando a assimetria funcional aumenta com a idade, há uma dificuldade em se determinar a contribuição exata de cada fator etiológico envolvido. A influência da oclusão 
no desenvolvimento das estruturas faciais harmoniosas exerce grande importância durante os primeiros anos de vida.

A assimetria facial com o desvio da linha média mandibular e do mento para um lado, desenvolve-se quando o crescimento da mandíbula de um lado é maior ou menor quando comparado com o lado oposto. As causas podem variar, e a assimetria pode ser congênita ou adquiria ${ }^{66}$. Com o propósito de testar a hipótese de que o deslocamento permanente do disco da articulação temporomandibular (ATM) é um fator causal no desenvolvimento da assimetria da linha média mandibular, LEGRELL e ISBERG ${ }^{66}$ realizaram um estudo em uma amostra total de 21 coelhos brancos, dividida em três grupos com sete animais em cada grupo. Os animais do primeiro grupo (o grupo experimental) foram submetidos à cirurgia para criar um deslocamento do disco articular na ATM direita, os do segundo grupo (o grupo de simulação) foram submetidos à cirurgia de abertura na ATM direita, porém sem manipulação do disco articular e os do terceiro grupo foram de controle. O estudo terminou após o fim do período de crescimento dos animais. Três implantes de tântalo foram inseridos no lado direito do corpo da mandíbula de cada animal no primeiro dia de experimento para estudar o crescimento longitudinal da mandíbula. Foi observada uma remodelação dos côndilos no grupo experimental e uma assimetria no comprimento da mandíbula com o lado do deslocamento do disco menor, com a sínfise da mandíbula desviada para este lado e desvio da linha média mandibular.

$\mathrm{Na}$ face humana, as linhas que passam pelas fendas palpebrais, bem como pelas comissuras labiais, não são paralelas, mas sim suavemente oblíquas; além disso, a linha mediana da face não é retilínea, mas ligeiramente convexa. Verificamos que, geralmente, a linha mediana da face é ligeiramente convexa para a direita, e coincide com um eixo ocular, oblíquo para cima e para a direita, e com um eixo bucal, oblíquo para baixo e também para a direita; e o pavilhão da orelha que é, geralmente, maior e mais alto à esquerda. Portanto, estas ocorrências indicam um maior desenvolvimento da metade direita da face ${ }^{2}$.

O corpo humano, e por conseqüência, a sua face, em condições normais de desenvolvimento, é assimétrica. Não podemos nos esquecer que apesar de assimétrica, a face humana é harmônica, pois essa assimetria é uma 
assimetria normal. Tais assimetrias podem ser evidenciadas através de planos horizontais e verticais, que permitem a sua mensuração. A primeira vista, a face harmônica nos induz a acreditar que se trata de uma face perfeitamente simétrica. No entanto, se traçarmos planos de orientação, verificaremos que a mesma apresenta assimetria, mas se trata de assimetria normal. $O$ desenvolvimento da assimetria normal pode ser perturbado, resultando em assimetrias anormais. Para averiguarmos as proporções faciais no sentido vertical utilizamos os quintos faciais: sendo que o primeiro destes quintos se limita do contorno da face até a comissura lateral das pálpebras; o segundo está limitado pelas comissuras lateral e mediana das pálpebras; o terceiro encontra-se entre as comissuras palpebrais medianas de um e do outro lado da face, que corresponde à distância entre as faces externas das asas do nariz; conseqüentemente, o quarto e o quinto são semelhantes, respectivamente, ao segundo e ao primeiro quinto, porém, do lado oposto da face. Para as observações no sentido horizontal, dividimos a face em terços, de modo que, o terço superior fica compreendido entre a raiz do cabelo e a linha das sobrancelhas, o terço médio é limitado pela linha das sobrancelhas e a linha subnasal, enquanto que o terço inferior da face localiza-se entre a linha subnasal e o mento. Os terços de uma face equilibrada, além de se manterem com medidas semelhantes entre si, geralmente, apresentam sua altura entre $55 \mathrm{~mm}$ e $65 \mathrm{~mm}$.

\subsubsection{CAUSAS DA ASSIMETRIA CRANIOFACIAL}

A assimetria, provavelmente, é o resultado de uma deformação do padrão de crescimento, da destruição do centro vital de crescimento, paralisias e outras condições que exercem influência durante o período de crescimento. Por outro lado, existem alguns casos de assimetria que ocorrem imediatamente pela perda óssea nos maxilares (por exemplo: o tratamento de um carcinoma), ocorrendo mais em pacientes adultos. Nos tempos de guerra, as assimetrias faciais ocorrem em homens devido à destruição óssea e do tecido mole por projéteis. Estas injúrias também ocorrem pela radiação, onde muitas vítimas 
são crianças. Em outros casos a etiologia não é muito evidente. A má oclusão não é uma das causas da assimetria da face, mas sim um dos sinais ${ }^{131}$.

A assimetria facial constitui-se num dos maiores problemas para os ortodontistas, pois apresenta um difícil diagnóstico. A classificação da severidade da assimetria torna-se fundamental para um plano de tratamento correto. A assimetria pode ocorrer devido à presença de um ou mais componentes cranianos ou faciais bilaterais (tecidos moles e ossos) não eqüidistantes da linha média ou quando o centro de cada estrutura ímpar não coincide com o centro desta linha. Estas assimetrias podem ter efeitos secundários na dentição e na oclusão, podendo apresentar problemas clínicos maiores associados, quando são severas ${ }^{72}$. Como exemplo deste tipo de assimetria, podemos citar as fissuras labiopalatais ${ }^{25}$.

Um número substancial de injúrias craniofaciais ocorre em idades precoces. Tanto em adultos como em crianças a parte mais vulnerável da mandíbula é o colo do côndilo. Uma fratura unilateral do corpo da mandíbula normalmente está associada com a fratura do côndilo no lado oposto. Freqüentemente ocorre uma regeneração completa do côndilo em pacientes jovens, sem sinais de fratura, e a regeneração ocorre melhor em pacientes com crescimento ativo e abaixo dos 12 anos de idade. A anquilose é causada por uma infecção ou artrite, e secundariamente por trauma ${ }^{100}$.

A assimetria mandibular é um fenômeno muito comum ${ }^{139}$. Diversas causas da assimetria mandibulares têm sido propostas, incluindo a hiperplasia/hipoplasia condilar ${ }^{88,131}$, a fratura condilar ${ }^{88,125}$, a anquilose da ATM $^{71,100,125}$, tumor na região da ATM, desordens intra-articulares, assim como desordem interna associada com artrose ${ }^{113}$ ou artrite inflamatória e genética ${ }^{139}$. O trauma pré-pubescente da mandíbula tem sido indicado como causa da assimetria mandibular, contudo nunca foi comprovado.

A assimetria facial aparente ocorre também devido a uma deficiência no corpo mandibular de um lado (que pode ser avaliada através da radiografia submentoniana), ou pelo crescimento vertical maior de um côndilo (observado através da radiografia póstero-anterior) ${ }^{139}$.

Em 1985, ARVYSTAS; ANTONELLIS e JUSTIN , afirmaram que existem diversos fatores etiológicos diferentes que contribuem para uma assimetria facial esquelética severa. Os principais fatores esponsáveis pelo 
desenvolvimento desta assimetria são: inflamatórios, de desenvolvimento, neoplasia, traumatismo, funcional e neurológicos (lesão unilateral do $5^{\circ}$ ao $7^{\circ}$ núcleo, injúria do $7^{\circ}$ nervo craniano).

Certamente não há face perfeitamente simétrica, contudo a ausência de uma assimetria severa é necessária para uma estética facial aceitável ${ }^{31}$. Essa "assimetria normal", a qual resulta de uma pequena diferença de tamanho entre os dois lados da face, deve ser distinguida de um grande desvio do queixo ou nariz ${ }^{126}$.

SKOLNICK et al. ${ }^{123}$, em 1994, para determinar a possível associação entre o trauma pré-puberal com a assimetria da face e da mandíbula, avaliaram 56 pacientes de cirurgia ortognática e 109 pacientes ortodônticos. Foram tomadas radiografias póstero-anteriores de todos os pacientes em relação cêntrica e com o Plano de Frankfurt paralelo ao solo. Uma linha vertical de referência foi construída ligando o centro da Crista Galli ao centro da espinha nasal anterior, estendendo-se até a borda inferior da mandíbula. Esta linha definia o plano médio sagital da face. Partindo da intersecção desta linha com a borda inferior da mandíbula foram traçadas linhas até o ângulo goníaco em ambos os lados (direito e esquerdo). A altura dessas duas linhas foi medida diretamente no traçado e uma diferença de $3,0 \mathrm{~mm}$ ou mais foi definida como assimetria mandibular. Foi encontrada relação estatisticamente significante entre a evidência radiográfica de assimetria mandibular e a história de trauma pré-puberal da face. Deve ser mencionado que esta relação estatisticamente significante,não confere a relação de causa entre os dois.

Segundo LEGAN ${ }^{65}$, em 1998, as causas das assimetrias dentofaciais, geralmente, incluem más-formações genéticas ou congênitas, como a microssomia hemifacial; fatores ambientais, como o trauma; desvios funcionais; desvios mandibulares resultantes de interferências dentárias; fatores epigenéticos e adquiridos, como infecções ou patologias. 0 desenvolvimento da assimetria facial com desvio da linha média e do mento para um lado ocorre quando o crescimento mandibular de um lado aumenta ou diminui, comparando-se com o do lado oposto. Várias causas podem estar relacionadas, podendo a assimetria ser congênita ou adquirida. 


\subsection{A CLASSE II, SUBDIVISÃO}

A má oclusão de Classe II tem sido assunto de contínuo estudo desde que foi descrita por $\mathrm{ANGLE}^{4}$, no final do século XIX, quando apenas eram postos em evidência, os aspectos dentários. ANGLE ${ }^{5}$, em 1907, constatou uma incidência de aproximadamente $25 \%$ de má oclusão de Classe II, dentre os pacientes ortodônticos, e ainda, classificou as más oclusões de Classe II unilaterais em casos de subdivisão. Ele acreditava que a relação molar de Classe II se desenvolvia como resultado da erupção distal do primeiro molar inferior em relação à posição normal do primeiro molar superior do lado da Classe II.

A subdivisão na Classe II ou III de Angle pode ser ocasionada em parte por uma orientação assimétrica do arco dentário superior, onde a mandíbula não mostra assimetria correspondente ${ }^{70}$.

A má oclusão de Classe II, subdivisão caracteriza-se pela relação oclusal de Classe II de um lado do arco dentário e Classe I do outro ${ }^{26,55,56,60}$, onde o desvio da linha média é comum ${ }^{60}$, sendo que este tipo de má oclusão possui uma incidência de $50 \%{ }^{3}$. Enquanto na distribuição geral das más oclusões a Classe II tem uma incidência de cerca de $42 \%{ }^{121}$.

Pontos de contatos prematuros ou o mal posicionamento dos dentes superiores e/ou inferiores leva a um deslocamento da mandíbula, para que o paciente oclua numa posição mais confortável $(\mathrm{MIH})$, o que ocasiona uma má oclusão de Classe II mais acentuada em um lado69. Em 1976, LEWIS $^{69}$ concluiu que deve ser realizada uma avaliação da causa deste desvio, demarcando-se com um lápis uma linha vertical passando no centro do filtro do lábio superior e uma linha vertical passando no centro do queixo. Os lábios devem permanecer selados e relaxados, com o paciente em $\mathrm{MIH}$. Quando a linha superior coincidir com a linha média dentária superior, significa que o desvio está no arco inferior. Quando a linha superior não coincidir com a inferior, é possível que haja um desvio lateral da mandíbula.

O desvio da linha média pode indicar a assimetria dentária, ou seja, pode indicar que um lado da oclusão é mais Classe II do que o outro ${ }^{139}$. Quando manipulamos o paciente em relação cêntrica, os dentes inferiores 
posicionam-se mais distalmente do que os superiores, causando um desvio da linha média, com a linha média inferior desviada para o lado deficiente ${ }^{139}$. Pode ser encontrado em todas as más oclusões, mas é mais freqüente na Classe II.

Baseando-se em três casos de má oclusão de Classe II, subdivisão com etiologia e tratamento distintos, em 1975, WERTZ ${ }^{136}$ relatou a dificuldade em se diagnosticar e tratar pacientes com Classe II unilateral devido à sua origem multifatorial. $\mathrm{O}$ autor salientou a importância em verificar se a origem da assimetria é dentária ou esquelética. Além disso, comentou que tanto para a Classe II como para a Classe III, subdivisão, a sínfise encontra-se desviada para o menor lado da mandíbula em relação à linha média facial, havendo também desvio mandibular. Nos casos de discrepância severa do crescimento mandibular, necessitava-se de uma correção cirúrgica que dependia da quantidade de distorção facial presente. Nas assimetrias dentárias, os segmentos dos arcos dentários destes pacientes devem ser identificados individualmente para o estabelecimento do correto plano de tratamento. Nestes casos, utiliza-se um dispositivo como um dos métodos de determinação da assimetria dentária em modelos de estudo. Para a sua aferição, tem-se como parâmetro a rafe palatina mediana como eixo de simetria, transferindo-se para o modelo inferior, em oclusão. Nos modelos superior e inferior, traçam-se duas perpendiculares a esta linha palatina mediana, ou seja, uma passando pela distal do molar localizado mais posteriormente no arco dentário e a outra, pelos pré-molares. Desta forma, a posição ântero-posterior dos dentes em cada um dos quatro quadrantes, pode ser avaliada, assim como o segmento responsável pela relação ânteroposterior incorreta. Enfatizou a raridade em se encontrar qualquer magnitude de desarmonia esquelética, nestes casos, concluindo que devem ser diagnosticados e tratados, baseando-se no problema individual específico e evitando o emprego do mesmo método de tratamento para todos os casos.

Quando a assimetria mandibular está presente, a severidade da má oclusão de Classe II é maior de um lado. A Classe II, subdivisão é um exemplo típico, onde a má oclusão é acentuada no lado menos desenvolvido ${ }^{139}$.

Com o propósito avaliar a diferença estatisticamente significante em relação à assimetria facial e o arco dentário nos pacientes com má oclusão 
de Classe II, subdivisão de Angle e nos pacientes com oclusão normal, ALAVI; BEGOLE e SCHNEIDER ${ }^{1}$, em 1988, estudaram 56 pacientes, sendo 28 em cada grupo, com idade média de 17,1 anos, apresentando a dentição permanente até os primeiros molares. As medidas foram obtidas por meio de radiografias cefalométricas laterais, póstero-anteriores e de modelos de estudo. Verificaram que a assimetria ântero-posterior das más oclusões de Classe II, subdivisão ocorria principalmente devido à posição mais distal do molar inferior do lado da Classe II, não sendo possível determinar se a posição deste dente era devido a uma assimetria esquelética ou dentária. A assimetria na região dentoalveolar superior apareceu como causa secundária.

ROSE et al. ${ }^{107}$, em 1994, compararam a simetria mandibular de 58 pacientes. Foram utilizados dois grupos, um grupo experimental de 28 pacientes com má oclusão de Classe II, subdivisão, apresentando idade média de 28,4 anos, e um controle de 30 pacientes com má oclusão de Classe I, com idade média de 24,9 anos. Destes pacientes, 44 eram do gênero feminino e 14 do gênero masculino. Foram tomadas radiografias submentonianas prétratamento de todos os pacientes. A simetria foi avaliada medindo-se a diferença espacial relativa de pontos mandibulares nas dimensões ânteroposterior e transversa, determinadas pelos sistemas de coordenadas que representavam a mandíbula, o assoalho craniano e os dentes inferiores. Este trabalho limitourse somente ao estudo da mandíbula, uma vez que as radiografias submentonianas não são específicas para a análise dos pontos maxilares. Somente as variáveis que representavam a diferença ânteroposterior entre as posições dos molares inferiores direito e esquerdo demonstraram diferença estatisticamente significante entre os grupos. $O$ primeiro molar inferior, quando avaliado em relação à base do crânio ou à mandíbula, estava localizado mais posteriormente no lado da Classe II, nas más oclusões com subdivisão, em uma mandíbula que não exibia nenhuma assimetria. Qualquer diferença encontrada na assimetria mandibular não excluiu a possibilidade da presença de assimetria dentoalveolar ou esquelética no arco superior contribuir para as más oclusões com subdivisão. Concluíram que a mandíbula na Classe II, subdivisão não exibe uma posição esquelética anormal nem mesmo assimetria esquelética, sendo esta má oclusão decorrente das assimetrias dentárias. 
Com o objetivo de determinar a presença ou não de assimetria esquelética e/ou dentária em pacientes com má oclusão de Classe II, divisão 1 subdivisão, ARAÚJO et al. ${ }^{6}$ realizaram um estudo, cuja amostra consistiu de 30 pacientes com má oclusão de Classe II, divisão 1, subdivisão, direita ou esquerda, como descrita por Angle. Foram obtidas radiografias pósteroanteriores (PA) para verificar a presença de assimetria entre os lados de Classe I e de Classe II, divisão 1, subdivisão e modelos de estudo dos pacientes para se determinar a freqüência destas assimetrias. Nove triângulos bilaterais foram traçados nos cefalogramas para descrever o complexo craniodentofacial. A área de cada triângulo foi calculada nas radiografias e a freqüência das assimetrias ântero-posterior e transversal foi avaliada nos modelos. Os resultados não demonstraram diferença estatisticamente significante entre as áreas dos triângulos medidos nos lados de Classe I e II e no desvio da linha média superior e inferior nas radiografias. Contudo, foi encontrada uma diferença estatisticamente significante na linha média do modelo. Não foi observado envolvimento esquelético na má oclusão de Classe II, subdivisão, quando da análise da radiografia PA. A freqüência de assimetria na posição do molar, encontrada nos modelos, foi significante maior no inferior do que no superior. As más oclusões de Classe II, divisão 1, subdivisão são caracterizadas por desvios dentários e não por displasias esqueléticas, no plano frontal.

Em 1998, JANSON ${ }^{55,56}$, realizou um estudo com o objetivo de determinar se existe uma diferença significante com relação à assimetria dentária e esquelética entre pacientes com má oclusão de Classe II, subdivisão e pacientes com oclusão normal. A amostra consistiu de 30 pacientes em cada um dos dois grupos, onde todos os pacientes apresentavam a dentadura permanente completa até os primeiros molares. As medidas foram obtidas das radiografias submentoniana, póstero-anterior e oblíqua corrigida. Na radiografia submentoniana, a simetria foi avaliada medindo-se as diferenças relativas na posição espacial dos pontos dentários e esqueléticos entre os lados direito e esquerdo, nas dimensões ântero-posterior e transversal. Sistemas de coordenadas foram utilizadas para representar a mandíbula, o assoalho do crânio e a maxila. Na radiografia póstero-anterior (PA), a simetria foi avaliada similarmente medindo-se a diferença relativa nas posições espaciais dos 
pontos dentários e esqueléticos entre os lados direito e esquerdo. $\mathrm{Na}$ radiografia oblíqua corrigida, a simetria foi avaliada medindo-se as diferenças no tamanho das estruturas dentárias e esqueléticas entre os lados direito esquerdo. Os resultados demonstraram que o fator principal da diferença entre os dois grupos foi o posicionamento distal do primeiro molar inferior no lado da Classe II nos pacientes cujas mandíbulas não demonstraram assimetria esquelética ou de posição. O segundo fator foi o posicionamento mesial do primeiro molar superior no lado da Classe II. Além disso, a análise da radiografia PA demonstrou que ocorre mais o posicionamento distal dos molares inferiores no lado da Classe II, quando comparado com 0 posicionamento mesial dos molares superiores neste lado, resultando no desvio da linha média dentária inferior para o lado da Classe II mais freqüentemente do que a linha média superior para o lado oposto.

\subsection{A ASSIMETRIA CRANIOFACIAL E A CLASSE II, SUBDIVISÃO}

Correlacionando-se a assimetria da posição bicondilar com a assimetria oclusal, pacientes com más oclusões demonstraram uma posição mais assimétrica dos côndilos em relação à parede posterior da fossa glenóide. A assimetria condilar foi encontrada em adultos jovens, sendo esta assimetria no plano sagital significantemente relacionada aos desvios de linha média dentária e relações oclusais. Nos casos de má oclusão subdivisão, a distância côndilo-fossa sofreu um aumento unilateral ${ }^{96}$.

Uma má oclusão assimétrica pode resultar da presença de uma assimetria esquelética verdadeira, uma assimetria dentária ou a combinação de ambas $^{120}$. Durante o diagnóstico diferencial da assimetria dentária, uma avaliação cuidadosa da relação dentária ântero-posterior deve ser realizada em relação cêntrica e a presença de um desvio funcional entre a relação cêntrica e a máxima intercuspidação habitual deve ser registrada. Quando a posição de relação cêntrica for difícil de ser encontrada, pode ser prescrito ao paciente um splint de desprogramação para auxiliar no posicionamento correto da posição de relação cêntrica. Este procedimento é importante para eliminar a possibilidade de uma falsa assimetria dentária, resultado de um desvio da 
mandíbula durante o fechamento. A assimetria dentária posterior pode resultar da presença de uma rotação do molar ou de uma inclinação mesiodistal deste molar. A presença de uma rotação molar unilateral no arco dentário superior pode indicar uma relação de Classe II deste lado, assim como a discrepância entre a inclinação mesiodistal do primeiro molar permanente direito e esquerdo, necessitando de um diagnóstico e da correção durante os estágios iniciais do tratamento. Pois esta relação não se autocorrige com o crescimento.

Pouco se sabe a respeito da prevalência das assimetrias ortodônticas. Em 1998, SHEATS et al. ${ }^{118}$ fizeram uma estimativa da magnitude de prevalência da assimetria dentária e facial em jovens americanos, sem história de tratamento ortodôntico prévio e compararam com os dados estatísticos de um grupo submetido ao tratamento ortodôntico. A assimetria sagital do molar era encontrada em $30 \%$ dos jovens do primeiro grupo e em $23 \%$ dos jovens do segundo grupo. Uma avaliação adicional da assimetria no segundo grupo mostrou $12 \%$ de assimetria facial e $21 \%$ de não coincidência das linhas médias dentárias. No grupo de pacientes em tratamento, verificaram que a assimetria mais comum era o desvio da linha média inferior em relação à linha média facial, ocorrendo em $62 \%$ dos pacientes. Outras assimetrias ocorreram em ordem decrescente: falta de coincidência das linhas médias dentárias (46\%); desvio da linha média maxilar em relação à linha média facial (39\%); má oclusão assimétrica (22\%); assimetria oclusal maxilar (20\%); assimetria oclusal mandibular (18\%); assimetria facial (6\%); desvio do mento (4\%) e desvio nasal (3\%). Concluíram que não há associações significantes entre a assimetria facial e a ausência de coincidência das linhas médias. Entretanto, associações estatisticamente significantes foram encontradas em relação à assimetria do molar e a assimetria facial, a assimetria do molar e a não coincidência das linhas médias e a assimetria do molar e o tipo racial. Os resultados desta pesquisa não puderam ser considerados precisos devido à deficiente metodologia para a avaliação da assimetria. Os examinadores não foram adequadamente calibrados e ainda, os pacientes avaliados não foram analisados quanto à presença de desvios da relação cêntrica para a máxima intercuspidação habitual e nem mesmo, com relação à coincidência das linhas médias. 
A mandíbula exerce uma contribuição dominante para a assimetria dentofacial já que forma o suporte esquelético dos tecidos moles da face inferior. De modo contrário, a maxila contribui com um suporte mínimo para os tecidos moles, apresentando pequena participação na assimetria. A maioria das assimetrias maxilares é secundária ao crescimento mandibular assimétrico, podendo ser mensurada simplesmente pela localização da linha média dentária superior e pela inclinação do plano oclusal frontal ${ }^{65}$.

Um dos objetivos do controle do desenvolvimento oclusal e da correção da má oclusão consiste no estabelecimento de uma simetria na forma dos arcos individualmente e do relacionamento oclusal maxilomandibular. A simetria da forma dos arcos relaciona-se com as inclinações axiais e rotações dos dentes individualmente. A oclusão não somente é afetada pela posição dos dentes, mas também pelo padrão de crescimento esquelético. As assimetrias mandibulares podem estar relacionadas não somente com uma posição assimétrica, como também em relação à morfologia assimétrica mandibular. Diferenças no comprimento do corpo mandibular, bem como, na altura do ramo podem estar relacionadas com as assimetrias. O desenvolvimento de uma assimetria pode se iniciar na vida fetal, podendo também ser resultante de distúrbios do desenvolvimento pós-natal, como o trauma do côndilo mandibular ${ }^{62}$.

A assimetria facial decorrente do deslocamento lateral da mandíbula é significante em pacientes com desordens temporomandibular ${ }^{53}$. A assimetria dentária em pacientes com desordens temporomandibular foi avaliada por meio de cefalogramas póstero-anteriores e de modelos de estudo por INUI; FUSHIMA e SATO ${ }^{38}$, em 1999. O desvio lateral da linha média inferior e a diferença da relação molar em ambos os lados (direito e esquerdo) foram examinados, e sua relação com o deslocamento lateral da mandíbula. O desvio lateral da linha média inferior e a diferença da relação molar foram significantemente correlacionados com o deslocamento lateral da mandíbula. Em muitos casos, o lado do deslocamento da linha média inferior foi coincidente com a linha média mandibular esquelética. Estes resultados sugerem que nos pacientes com desordem temporomandibular as assimetrias na relação oclusal da linha média inferior e dos molares foram mantidas de acordo com a assimetria esquelética mandibular. Muitos casos apresentaram 
uma relação oclusal mais distal do primeiro molar no lado deslocado da mandíbula quando comparado com o lado oposto. Foi encontrada uma alta incidência de relação de Classe II (61,8\%) e mais evidente no lado deslocado da mandíbula. A discrepância da linha média e a diferença na relação molar em ambos os lados são uma característica oclusal importante nos pacientes com desordem temporomandibular.

\subsection{MÉTODOS DE DIAGNÓSTICO DAS ASSIMETRIAS}

SVED ${ }^{128}$, no ano de 1931, afirmou que o simples exame visual direto pode ser mais preciso do que um bom método científico para o reconhecimento das assimetrias faciais. Mais tarde, em 1942, MOORE e HUGHES $^{80}$, utilizaram a observação direta para analisar seus pacientes na cadeira odontológica. Porém autores como CAMPBELL ${ }^{22}$, afirmaram que a visão não consistia num método preciso para avaliação da assimetria facial.

A avaliação da morfologia craniofacial é uma ferramenta indispensável na prática clínica e na pesquisa e pode ser realizada de diversas maneiras. As radiografias cefalométricas e as fotografias são os métodos mais apropriados e mais utilizados ${ }^{34}$. As radiografias mais comumente utilizadas para observarmos a assimetria craniofacial são: a póstero-anterior (PA) e a submentoniana ${ }^{68}$.

Existem muitos métodos para a avaliação da assimetria facial, o mais antigo é o método antropométrico, onde são realizadas medidas diretamente no crânio, porém o método mais comum é a análise através de radiografias cefalométricas. FARKAS e $\mathrm{CHEUNG}^{32}$, em 1981, utilizaram a antropometria para avaliar a prevalência e a extensão da assimetria nos terços superior, médio e inferior da face e a relação entre as várias assimetrias. A assimetria facial foi avaliada por meio de seis pares de medidas projetadas na superfície lateral da face, cinco oblíquas e uma perpendicular. A medida foi considerada assimétrica quando a diferença entre os dois lados foi de $2 \mathrm{~mm}$ ou mais. Os autores concluíram que: as assimetrias, embora não evidentes, são muito comuns; o maior número de assimetrias ocorreu no terço superior da face no gênero masculino aos 18 anos. A menor quantidade de assimetria foi 
encontrada na medida órbita-tragus no gênero masculino aos 6 anos. A diferença média entre as medidas assimétricas foi em média de $3 \mathrm{~mm}$ ou $3 \%$ para ambos os gêneros. Geralmente, o lado direito apresentou mais longo do que o esquerdo. $O$ gênero e a idade não influenciaram significantemente na prevalência das assimetrias.

O diagnóstico das assimetrias dentárias e esqueléticas pode ser realizado pela avaliação esquelética do paciente e pelo padrão do tecido mole facial. As radiografias submentoniana e póstero-anterior são, particularmente, aplicáveis para o diagnóstico das assimetrias. A radiografia submentoniana auxilia mais precisamente no diagnóstico da assimetria, principalmente quando o problema é mandibular. As radiografias especializadas, como as tomografias computadorizadas e a utilização da estereometria com ou sem implantes, oferecem mais informações, porém consistem em recursos excessivamente sofisticados para o diagnóstico. Além disso, o tecido mole da face, a observação clínica precisa do aspecto frontal e inferior, juntamente com as fotografias faciais contribuem no diagnóstico para a detecção da existência de um problema esquelético ${ }^{21}$.

É de suma importância o diagnóstico dos casos de má oclusão de Classe II, subdivisão em relação cêntrica para se verificar a real discrepância ântero-posterior que o paciente apresenta ${ }^{21,102}$. A máxima intercuspidação habitual pode ser uma forma duvidosa de diagnóstico, pois muitos pacientes demonstram desvios mandibulares que podem mascarar ou acentuar a assimetria presente ${ }^{21}$. A desprogramação da musculatura mastigatória com uma placa oclusal pode ser efetiva na obtenção do correto registro de mordida em relação cêntrica, antes de se realizar qualquer planejamento irreversível. A severidade da discrepância da linha média pode ser aumentada ou diminuída, dependendo de como a mandíbula se reposiciona ${ }^{102}$. Desta forma, a análise facial, o exame intrabucal e de modelos, bem como os exames radiográficos atuam na melhor elaboração da planificação do tratamento a ser implementado. Mais precisamente, a identificação do arco dentário que apresenta a assimetria facilita a previsão do número de dentes a serem extraídos. 


\subsubsection{AVALIAÇÃO CLÍNICA, FOTOGRÁFICA E EM MODELOS DE ESTUDO}

A assimetria facial tem sido extensivamente estudada por meio de fotografias, obtidas dos lados direito e esquerdo da face e montadas com suas respectivas imagens em espelho. $\mathrm{Na}$ avaliação das três fotografias (face normal, face direita e face esquerda) parecem ser três pessoas diferentes ${ }^{131}$.

HERZBERG ${ }^{50}$, em 1952, foi o primeiro autor a introduzir as fotografias no estudo das faces, ele afirmou que provavelmente, a melhor maneira de desenvolver a habilidade na avaliação das faces consiste na observação direta, criteriosa e repetida. Demarcando-se os pontos anatômicos na face dos pacientes a serem analisados, muitas medidas podem ser calculadas precisamente por meio das fotografias ${ }^{39}$. As fotografias faciais e intrabucais constituem-se instrumentos indispensáveis para a documentação das condições iniciais, bem como para o estabelecimento da lista de problemas e do planejamento, sendo essenciais também na avaliação dos resultados do tratamento ${ }^{65}$.

A avaliação dos modelos de gesso do paciente é de grande importância para a determinação das diferenças significantes dos arcos dentários. Para a realização desta avaliação uma linha de referência deve ser construída, utilizando-se a porção distal da papila palatina e a borda posterior da rafe palatina mediana, estes pontos são transferidos para o modelo inferior, e as pontas de cúspides vestibulares dos dentes posteriores e os pontos incisais médios dos dentes anteriores devem ser demarcados no modelo com o auxílio de um lápis. As medidas lineares são realizadas de cada um dos sete pontos (dentes) em ambos os lados, transversalmente em direção a rafe palatina mediana. Uma linha de referência, perpendicular a rafe palatina mediana construída através do ponto médio entre os incisivos centrais, também é traçada onde são obtidas as medidas no sentido ântero-posterior. As assimetrias são calculadas pela determinação da diferença absoluta entre as medidas homólogas obtidas das linhas de referência. Essas medidas são realizadas no arco dentário superior e inferior ${ }^{1}$.

Em 1993, FERRARIO et al. $^{34}$, utilizaram um protocolo padronizado para descrever quantitativamente a estrutura do tecido mole craniofacial, os relacionamentos entre as estruturas faciais e a postura da 
cabeça em relação ao solo. A amostra consistiu de 51 indivíduos do gênero feminino e 57 do gênero masculino, com idades de 20 a 27 anos e leucodermas. Foram obtidas cinco fotografias de cada indivíduo, sendo duas frontais e três do lado direito da face. No gênero masculino as faces mostraram-se, em média, mais largas e mais longas do que no gênero feminino, com as maiores diferenças nas regiões da boca e do mento. Ambos os gêneros eram, de forma geral, simétricos. Os indivíduos que eram assimétricos, compensaram esta assimetria pela alteração da postura da cabeça em relação ao solo, de tal forma que no plano frontal o eixo interpupilar e o plano oclusal apresentaram-se paralelos ao solo.

Para a tomada das fotografias alguns autores ${ }^{34,81,133}$ utilizam a posição natural da cabeça, pois afirmam que é a que o paciente conduz no seu dia-a-dia. Outros autores ${ }^{28,137}$ utilizam o plano interpupilar paralelo ao solo, afirmando que este plano, paralelo ao plano de Frankfürt, é consistente e prático.

Os modelos, as análises cefalométricas e a análise facial em conjunto são a base para o sucesso do diagnóstico e do plano de tratamento do paciente. Os modelos e/ou o exame clínico da oclusão indicam ao profissional a correção necessária. A análise facial deve ser realizada com 0 paciente em relação cêntrica, com os lábios relaxados e a cabeça na posição natural. Esta análise é utilizada para identificar os traços faciais positivos ou negativos e portanto como a oclusão pode ser corrigida para promover uma melhora na face do paciente ${ }^{7}$.

Fotografias faciais padronizadas foram utilizadas para comparar as alterações no perfil mole ${ }^{17}$ e para avaliar as mudanças nas dimensões faciais ${ }^{16}$. As fotografias foram digitalizadas e dispostas na tela de um computador, onde foram demarcados 38 pontos (18 frontais e 20 laterais). A partir destes pontos 29 medidas angulares e lineares (8 frontais e 21 laterais) foram obtidas. Os autores concluíram que: as fotografias permitem a medição das estruturas tanto no sentido frontal como lateral e que certos pontos tendem a ser menos confiáveis que outros, assim como, o subnasal e o gnátio. Em geral, as medidas nas fotografias frontais foram mais confiáveis do que aquelas das laterais, e as medidas lineares foram mais confiáveis do que as angulares $^{17}$. 
Muitos ortodontistas avaliam clinicamente a assimetria dentária pela comparação de pontos específicos nas superfícies oclusais dos modelos de gesso. Em 1998, MAURICE e KULA ${ }^{73}$ quantificaram e descreveram as assimetrias intra-arcos maxilomandibulares, determinando se havia um relacionamento entre as assimetrias intra e interarcos. O plano palatino mediano foi utilizado como referência para as medidas transversais e um mesmo plano foi construído no computador para as medidas ânteroposteriores. As assimetrias transversais excederam as assimetrias ânteroposteriores em magnitude e prevalência. A alta associação entre as posições ântero-posteriores e transversais interarcos indicaram que os arcos apresentavam dimensões similares. Concluíram que muitos jovens na dentadura mista apresentam assimetrias intra-arcos mais severas e constantes no plano transversal do que no sentido ântero-posterior e sugeriram que quando se encontra uma assimetria em um arco geralmente também ocorre em seu antagonista.

Mais tarde, no ano de 2001, EDLER; WERTHEIM e GREENHILL ${ }^{29}$, investigaram a concordância da avaliação clínica e computadorizada da assimetria mandibular. Doze fotografias padronizadas foram analisadas por 8 clínicos experientes gerando uma escala, da normalidade até a assimetria mandibular acentuada. Desenhou-se o contorno da mandíbula no computador e traçaram-se duas linhas: linha A (da inserção inferior de uma orelha à outra - Otobasion inferius) e linha B (na bissecção da linha $A$, perpendicular à mesma). Utilizaram-se quatro métodos para quantificar a assimetria, baseados nas diferenças direita/esquerda no perímetro, área, compactação e proporção do centro da área. Houve boa concordância na probabilidade de necessidade de tratamento, porém apenas concordância moderada quanto a um nível "aceitável" de assimetria. As diferenças nas proporções dos perímetros não se correlacionaram adequadamente com a avaliação clínica, entretanto, as análises de área e compactação demonstraram concordância absoluta. Já nas proporções das diferenças no centro da área, houve $75 \%$ de sensibilidade e $85 \%$ de especificidade na análise digital. Concluiu-se, portanto, que a avaliação computadorizada pode ser útil na definição dos contornos mandibulares e quantificação de assimetrias causadas pelo crescimento, tratamento e por recidivas. 


\subsubsection{RADIOGRAFIA ORTOPANTOMAGRÁFICA E CEFALOGRAMA LATERAL}

A distorção e a magnificação imprevisíveis da imagem da radiografia panorâmica limitam a precisão da sua informação. Entretanto, há a possibilidade de se detectar a assimetria mandibular, assim como as diferenças na forma e posição condilar entre os lados direito e esquerdo, a diferença entre a altura e a largura do ramo entre os dois lados, o grau de chanfradura antegoniana bilateral, a quantidade de desenvolvimento do corpo mandibular de ambos os lados, o desvio do ponto médio mandibular, a presença ou ausência do processo coronóide e a abertura do ângulo goníaco ${ }^{92,110}$.

As radiografias panorâmicas, apesar de serem pouco precisas e confiáveis, servem para avaliar o espaço disponível no segmento pósterosuperior antes de se implementar uma mecânica da movimentação distal do molar ${ }^{119}$.

\subsubsection{RADIOGRAFIA SUBMENTONIANA}

Descrita primeiramente em 1905 por SCHUELLER ${ }^{115}$ e posteriormente por MERRILL ${ }^{75}$ em 1949. A radiografia submentoniana revela informações valiosas, mostrando detalhes suficientes para a localização de inúmeros pontos cefalométricos. Os arcos dentários são vistos em relação um ao outro e com as estruturas ósseas adjacentes. As assimetrias esqueléticas, também, são observadas claramente na radiografia submentoniana, assim como a mandíbula e os côndilos ${ }^{41}$.

O primeiro autor a sugerir o uso da radiografia submentoniana para a avaliação da assimetria foi $B E R G E R^{13}$, em 1961. Para a obtenção desta projeção, determinou que a cabeça do paciente deveria estar posicionada num cefalostato, com o plano de Frankfürt, perpendicular ao solo. A distância entre o tubo e o filme deveria ser de $1,50 \mathrm{~m}$. Para a orientação da avaliação das estruturas anatômicas, demarcou e traçou diversos pontos, linhas e planos. $O$ ponto buccale foi localizado na região anterior da superfície interna do arco zigomático e o ponto angulare, na ponta de uma densa área radiopaca de 
forma triangular, formada pela união das bordas superior e inferior da órbita com o arco zigomático. Comentou que a conexão dos pontos buccale determina o plano buccale que passa pelos primeiros molares superiores, enquanto que a conexão dos pontos angulare determina o plano angulare que corta o arco dentário entre os caninos e pré-molares. O plano condilar passa pelos contornos mais distais de cada côndilo. Para a determinação de uma linha média sagital foi utilizado, como orientação, os seguintes pontos: crista Galli, crista frontalis, vômer, tubérculo do atlas, processo odontóide e crista occipital interna. Como a simetria absoluta do crânio consiste numa situação muito rara, não foi possível traçar uma linha reta unindo todos esses pontos, tornando-se necessária alguma interpolação. Para completar o sistema de coordenadas, foi utilizada uma linha, perpendicular à linha sagital mediana, cortando-a ao meio. Estas linhas e os planos de orientação permitiam uma melhor visualização das assimetrias dentoesqueléticas das más oclusões. Entretanto, o autor não testou a reprodutibilidade e validade dessa linha de referência.

Mais tarde, em 1964, BERGER ${ }^{14}$ demonstrou um método para determinar a linha média na radiografia submentoniana, desenhando uma linha passando pelo vômer, pela parte posterior do septo nasal e pela crista Galli. Afirmou que a radiografia submentoniana poderia ser utilizada simultaneamente com as projeções lateral e frontal para a análise das deformidades dentofaciais. Sugeriu que a linha média basilar uma vez construída poderia ser utilizada no estudo da assimetria facial.

A radiografia submentoniana pode ser incorporada na análise tridimensional das deformidades cranianas, especialmente quando as assimetrias não são detectadas em projeções laterais comuns ${ }^{84}$. Além disso, a radiografia submentoniana relaciona os dentes, bem como a maxila e a mandíbula com o esqueleto craniofacial.

O trabalho de MOSS e SALENTIJN ${ }^{82}$, em 1971, concluiu que a passagem e a localização dos feixes neuromusculares não podem ser violados durante o crescimento. Para tanto, basearam-se nos estudos da estabilidade e homogeneidade da localização do forame mentoniano que serviram de referência para o forame oval como pontos de construção para o eixo de referência sagital mediano. Advogaram que a radiografia submentoniana deve 
ser tomada com a cabeça posicionada de tal forma que o plano de Frankfurt esteja paralelo ao plano do filme e o plano sagital mediano pode ser derivado dos forames na base craniana. Em avaliações radiográficas de uma série relativamente grande de crânios em idades dentárias variadas, com implantes colocados no forame oval, mandibular e mentoniano, revelaram que suas posições foram estáveis durante o crescimento.

Os dados obtidos a partir da radiografia submentoniana são de grande importância da definição de deformidades do esqueleto craniofacial ${ }^{43}$.

$\mathrm{Na}$ avaliação da assimetria, a radiografia submentoniana é potencialmente mais eficiente do que a $P^{37}$. FORSBERG; BURSTONE e HANLEY ${ }^{37}$, em 1984, com o propósito de avaliar a assimetria esquelética em uma amostra de pacientes ortodônticos, obtiveram radiografias submentonianas de 10 pacientes. Os pacientes estavam sentados, com a cabeça voltada para trás com o plano de Frankfurt paralelo ao filme, o tempo de exposição foi de 1 segundo a $90 \mathrm{KVp}$ e $15 \mathrm{~mA}$ e a distância foi de $16 \mathrm{~cm}$. Nos casos onde se nota uma assimetria do meato auditivo externo, somente a oliva direita deve ser utilizada ${ }^{37}$. Todos os pacientes estavam posicionados em relação cêntrica. A análise cefalométrica proposta por Ritucci e Burstone foi utilizada para avaliar a assimetria na base do crânio, no complexo zigomaticomaxilar e na mandíbula. Medidas para avaliar a simetria bilateral da base do crânio foram realizadas em relação ao sistema de coordenadas que consistia da linha inter-espinhosa. Também foram avaliadas as simetrias da mandíbula e do complexo zigomaticomaxilar em relação à base do crânio. $A$ posição dos côndilos também foi analisada em relação ao eixo inter-espinhoso.

GRAYSON et al. ${ }^{44}$, em 1985, objetivaram aplicar o método de traçado cefalométrico multiplanos, utilizando a radiografia submentoniana e discutindo sua participação no diagnóstico e plano de tratamento ortodôntico. Nesta análise, o cefalograma foi traçado três vezes, definindo-se os pontos e as estruturas de três planos basilares e apresentando as instruções para o seu traçado. Os autores afirmaram que este método auxilia no reestabelecimento do relacionamento tridimensional que existe nos filmes radiográficos com duas dimensões. Descreveram, também, um método para orientar a construção da linha média ântero-posterior de estruturas da base do crânio. Esta linha média construída foi transportada para cada plano, sendo crítica para relacionar a 
localização e extensão da deformidade craniana na análise tridimensional. Neste trabalho, a análise cefalométrica basilar foi aplicada para o estudo de um indivíduo normal e de três pacientes com anormalidades craniofaciais, tais como: o hipertelorismo orbital, a sinostose craniofacial e a microssomia hemicraniofacial. Para cada caso, a análise cefalométrica foi aplicada e os resultados radiográficos discutidos. Concluíram que, os traçados pré-cirúrgicos nas radiografias submentonianas podem ser manipulados para simular as alterações esqueléticas previstas na cirurgia, como nas telerradiografias.

A radiografia submentoniana promove um método descritivo prático e funcional para determinar o deslocamento condilar e a assimetria da mandíbula. O posicionamento incorreto da cabeça do paciente pode reduzir a efetividade da análise ${ }^{68}$.

Em conjunto com a análise da assimetria desenvolvida por Ritucci e Burstone ${ }^{106}$ e publicada por Forsberg, Burstone e Hanley ${ }^{37}$, ARNOLD; ANDERSON e LILYEMARK ${ }^{8}$, em 1994, utilizaram a radiografia submentoniana para avaliação de 44 adultos. Esta análise da assimetria consiste na utilização de pontos anatômicos bilaterais, criando sistemas de coordenadas de referência que podem ser utilizados para avaliar outros pontos. Três componentes foram analisados: a base do crânio, 0 complexo zigomaticomaxilar e a mandíbula e cada componente apresentava estruturas que eram analisadas quanto à assimetria, em relação ao sistema de referência do forame espinhoso, assim como em relação ao sistema de referência na linha média, originário daquele componente. Os côndilos também foram analisados em relação ao eixo intercondilar (um eixo médio de referência derivado da própria mandíbula) para determinar sua posição simétrica em relação à mandíbula. Esse sistema de análise permite estabelecer se a mandíbula está assimetricamente posicionada em relação à base craniana, ou se a estrutura mandibular apresenta uma forma assimétrica. Portanto, a base craniana apresentou medidas de assimetria realizadas em relação ao sistema de coordenadas de referência mediosagital, derivado dos forames espinhosos bilaterais. O complexo zigomaticomaxilar utilizou a linha transpterigomaxilar e sua bissetriz perpendicular como linha de referência mediosagital para medir a assimetria na região facial média ${ }^{8,37}$. Finalmente, a mandíbula apresentava um sistema de referência de coordenadas baseadas na linha transcondilar e sua 
bissetriz perpendicular, para medir a assimetria dentro da mandíbula ${ }^{8,37}$. Diversas estruturas pareadas e não pareadas foram então avaliadas por comparação com esse sistema de coordenadas Foi mensurada a distância até as linhas médias, para as estruturas bilaterais, enquanto as diferenças foram calculadas e para as estruturas não pareadas, foi medida a distância até o plano sagital médio ${ }^{8}$.

\subsubsection{RADIOGRAFIA PÓSTERO-ANTERIOR (PA)}

A determinação do plano sagital mediano do crânio, em estudos com a radiografia $\mathrm{PA}$, é complexa e nem sempre possível ${ }^{54}$. Para tanto, alguns trabalhos procuraram aperfeiçoar este método de avaliação, propondo diferentes metodologias. HARVOLD ${ }^{46}$, em 1951, desenvolveu o método da linha-X para estabelecer o plano sagital mediano. Esta linha foi construída por meio de uma perpendicular à linha horizontal que conecta as suturas frontozigomáticas direita e esquerda, passando pelo ápice da crista Galli. A amostra consistiu de 80 crânios secos, com idades variando dos três aos 20 anos. Observourse que freqüentemente a espinha nasal anterior estava muito próxima a linha-X em mais de $90 \%$ das radiografias. Além disso, as distâncias foram medidas da linha- $X$ aos lados das bordas temporais do osso zigomático e da sutura zigomaticomaxilar, no processo malar, o índice de simetria determinado por estas análises nas radiografias PA foi muito próximo dos resultados antropológicos realizados diretamente em crânios secos. Foi concluído que era possível identificar com o auxilio da radiografia frontal, assimetrias do esqueleto facial com um considerável grau de precisão.

O maior obstáculo no uso da radiografia PA é a localização de pontos cefalométricos apropriados ${ }^{67}$. Para minimizar esta desvantagem, foram descritos pontos facilmente identificáveis, como: os contornos laterais e superior da órbita, a crista Galli, o ponto gônio, a base craniana anterior e a asa menor do osso esfenóide ${ }^{111}$.

MULICK $^{83}$, em 1965, descreveu uma técnica para obtenção de radiografias póstero-anteriores (PA) para a utilização no diagnóstico ortodôntico. Durante o traçado anatômico para a orientação no sentido 
horizontal, recomendou a utilização do eixo transporiônico, do eixo que passa pelos foramens redondos ou do eixo das suturas frontozigomáticas direita e esquerda. No sentido vertical a linha de referência construída foi: perpendicular a qualquer um dos três eixos horizontais, passando pelo maior número de estruturas anatômicas centrais; ou uma linha vertical absoluta, passando pelo maior número de estruturas anatômicas centrais. As estruturas anatômicas centrais utilizadas foram: a crista Galli, a sutura palatina mediana e o vômer. As aplicações das radiografias PA consistem na avaliação dos desvios da linha média, inclinação do plano oclusal, assimetria facial, desvios funcionais da mandíbula, tipologia mandibular, avaliações dentárias e análises de deformidades faciais.

Utilizando a radiografia PA para a avaliação da relação entre a oclusão e a presença ou ausência de assimetrias da mandíbula ou da base anterior do crânio no plano frontal, LETZER e KRONMAN ${ }^{67}$, em 1967, avaliaram 100 pacientes, sendo 50 apresentando uma oclusão normal e 50 com má oclusão de Classe I ou II. A idade variou de 9 anos a 11 anos e 11 meses em ambos os grupos e o gênero não foi considerado. Os resultados deste estudo não revelaram uma evidência estatisticamente significante na correlação entre a oclusão dentária e a simetria ou a assimetria da face.

A técnica de se utilizar as olivas metálicas para determinar as posições dos centros dos meatos apresenta precisão duvidosa, pois pode haver diferenças na espessura nos dois meatos e na compressibilidade dos tecidos moles sobre os mesmos. A utilização dos meatos para estabelecer pontos fixos para se determinar o eixo transverso do crânio torna-se incrédulo devido à sua estrutura ${ }^{127}$. Isto ocorre em função do desnível vertical e da posição mais à frente de um meato em relação ao outro. Assim como, as extremidades das olivas podem não preencher os meatos, é possível que o paciente apresente ligeira rotação ou inclinação da cabeça.

A radiografia PA e a submentoniana são tomadas com o paciente em relação cêntrica, para observarmos a assimetria da mandibular. A posição do côndilo, freqüentemente, influencia na avaliação da desarmonia esquelética $^{138}$.

Em 1985, ARVYSTAS; ANTONELLIS e JUSTIN , com o objetivo de estudar longitudinalmente o crescimento crânio-facial de uma paciente do 
gênero feminino com assimetria facial progressiva, utilizaram radiografias padronizadas póstero-anteriores e sagitais entre as idades de 4 anos e 8 meses e 10 anos e 10 meses. O diagnóstico da paciente foi realizado na infância como fechamento prematuro da sutura coronal esquerda, sem a paciente ter sofrido nenhuma intervenção cirúrgica, trauma, infecção ou complicações, como fatores causais da sinostose. As alterações esqueléticas foram avaliadas por meio de uma análise cefalométrica, onde foram demarcados três pontos na radiografia póstero-anterior: na borda orbitária direita (ponto $A$ ), na borda orbitária esquerda (ponto B) e o gnátio (ponto $C$ ), e um triângulo foi traçado a partir desses três pontos. A porção superior do crânio da paciente encontrava-se desviada para o lado esquerdo, o lado da sinostose, enquanto que a porção inferior encontrava-se desviada para o lado direito. $O$ desvio do pogônio ocorreu devido ao deslocamento da ATM. O crescimento do ramo mandibular ocorreu normalmente, em ambos os lados, para manter a posição centralizada da mandíbula.

A análise cefalométrica póstero-anterior foi desenvolvida com o objetivo de fornecer informações clínicas importantes sobre as localizações específicas e as dimensões das assimetrias faciais. Em 1987, GRUMMONS e VAN DE COPPELLO ${ }^{45}$ apresentaram uma análise de assimetria frontal que consistia na construção de quatro linhas horizontais de referência para mostrar os diversos níveis de paralelismo das estruturas faciais. A linha de referência média sagital (LRM) foi traçada a partir da crista Galli, tangenciando a espinha nasal anterior (ENA) até a região mentoniana, perpendicular ao plano horizontal (plano Z) que conecta as suturas frontozigomáticas. Consideraram a LRM como referência, pois se aproxima do plano visual formado pelo subnasal e os pontos médios entre os olhos e as sobrancelhas. A morfologia mandibular foi avaliada por meio de triângulos bilaterais a partir do côndilo, das chanfraduras antegonianas e do mentoniano e a comparação da assimetria maxilomandibular foi avaliada por meio de pares de triângulos. Concluíram que esta análise fornece um método prático e funcional de determinação da localização e quantidade de assimetria facial, apresentando grande valor clínico quando integrada com as informações das radiografias em norma lateral e submentoniana. 
Um outro método de mensuração das assimetrias por meio de radiografias frontais, baseou-se na utilização de uma linha de referência horizontal determinada nas margens superiores orbitárias e uma linha de referência vertical, no plano sagital mediano, construída em ângulo reto à linha supra-orbitária, passando pela crista Galli. A assimetria esquelética neste trabalho foi determinada pela medição dos ângulos entre 0 plano sagital mediano e uma linha da crista Galli a ENA e outra linha da crista Galli ao mentoniano ${ }^{33}$.

\subsubsection{RADIOGRAFIA OBLÍQUA A $45^{\circ}$ E CORRIGIDA}

A radiografia oblíqua foi introduzida na literatura por Cartwright $e$ Harvold, em 1954 e empregada por Posen em 1955 para medir a altura vertical do corpo da mandíbula ${ }^{11}$.

A radiografia oblíqua a $45^{\circ}$ é obtida rotando-se o cefalostato (as olivas) até que o plano sagital mediano da cabeça do paciente fique em $45^{\circ} \mathrm{em}$ relação ao chassi, com o chassi perpendicular ao feixe de raios- $x$ e a cabeça do paciente posicionada com o plano de Frankfurt paralelo ao solo. São tomadas radiografias dos lados direito e esquerdo da face ${ }^{11}$.

Utilizando radiografias oblíquas e laterais, HATTON e GRAINGER $^{49}$, em 1958, avaliaram 15 crianças de três anos de idade. Os traçados das radiografias foram realizados duas vezes, investigando um ponto de mensuração na telerradiografia e dois, na radiografia oblíqua direita, sendo uma medida vertical (altura do molar) e uma horizontal, medida mesiodistal mandibular, que conectava a distal do molar a mesial do canino. Testes estatísticos foram utilizados para avaliar as variações nos traçados e nas técnicas radiográficas e concluiurse que os erros podem ser considerados desprezíveis em comparação às diferenças entre os pacientes ${ }^{49}$.

BARBER; PRUZANSKY e KINDELSPERGER ${ }^{11}$, em 1961, utilizaram 10 crânios com marcadores de prata em onze locais de cada metade da mandíbula e em oito locais de cada metade da maxila, para medir o fator de distorção e a ampliação da radiografia oblíqua a $45^{\circ}$, permitindo a identificação destas áreas para posterior mensuração dos traçados. Foram realizadas 14 
medidas mandibulares e 12 medidas maxilares nas radiografias do lado direito e esquerdo e diretamente no crânio. Foi concluído que as medidas calculadas correlacionavam-se com as medidas reais em centésimos de milímetros na maioria delas e variaram não mais que $0,3 \mathrm{~mm}$ em qualquer medida. Esse pequeno grau de variação entre as medidas indicou boa confiabilidade das medições realizadas na projeção oblíqua ${ }^{11}$.

A medida dos comprimentos mandibulares nas radiografias oblíquas é imprecisa ${ }^{144}$. Na avaliação de pacientes cirúrgicos, apresentando assimetria mandibular por meio de radiografias oblíquas a $45^{\circ}$, pode-se verificar grandes diferenças nas mensurações dos comprimentos mandibulares direito e esquerdo. Contudo, quando é utilizada a radiografia submentoniana para a avaliação da posição mandibular, observa-se que para estes casos, a angulação correta da projeção oblíqua raramente é de $45^{\circ}$. O mento, geralmente, encontra-se desviado para o lado em que o comprimento mandibular é mais curto, resultando em diferença significante entre a relação dos planos mandibulares direito e esquerdo e o plano do filme, podendo assim alongar e aumentar a imagem subseqüente. A posição do plano mandibular em relação ao plano do filme deve ser ajustada para a obtenção de uma medida mais precisa, utilizando-se radiografias submentonianas ${ }^{144}$.

Objetivando eliminar as imprecisões das radiografias oblíquas a 45, em casos com assimetrias acentuadas, METAXAS ${ }^{76}$, em 1993, desenvolveu e testou o método da radiografia oblíqua corrigida, visando aumentar a precisão da medição do tamanho da mandíbula em ambos os lados. Para tanto, afirmou que se deve realizar inicialmente a radiografia submentoniana para que a determinação do ângulo entre o corpo mandibular e o eixo transporiônico, dos lados direito e esquerdo. Comentou que após a obtenção destes ângulos, obtêm-se radiográficas oblíquas corrigidas, de cada lado individualmente, em vez de se utilizar o ângulo médio de $45^{\circ}$. Verificou que este procedimento proporciona uma maior precisão da medição do comprimento mandibular. Desta forma, o autor estudou um crânio seco com vários graus de assimetria criados na mandíbula, objetivando avaliar e comparar os comprimentos mandibulares medidos nas radiografias oblíquas corrigidas, com os valores reais medidos diretamente no crânio seco. Colocou parafusos no corpo e ramo do lado esquerdo da mandíbula de maneira a 
simular 15 tipos de assimetrias. Radiografias oblíquas direita e esquerda foram obtidas para cada grau de assimetria mandibular, objetivando mensurar 0 comprimento mandibular em cada filme. Utilizou implantes no condílio e na sínfise, assim como em outros pontos, criando marcadores radiopacos nos filmes, eliminando-se a variabilidade nas medidas do comprimento mandibular. Realizou-se três repetições das medidas do comprimento mandibular para o teste intra-examinador, visando avaliar a precisão da metodologia empregada nesta pesquisa. Avaliou-se, também, as medidas calculadas e reais dos comprimentos mandibulares esquerdo e direito, nas 15 assimetrias simuladas. Concluiu-se que todas as medidas estavam dentro do padrão de precisão satisfatório e que para todas as assimetrias, a diferença entre os valores calculados e reais era menor que $1 \mathrm{~mm}$, demonstrando uma alta correlação neste estudo. Utilizando o centro geométrico dos lados mandibulares, GIAMBATTISTINI ${ }^{40}$, em 1997, avaliou a precisão da radiografia oblíqua corrigida, encontrando um valor menor do que foi verificado por METAXAS ${ }^{76}$. Isto decorreu devido à sua metodologia não ter utilizado a linha que passa pelos pontos médios condilares até o centro da sínfise mentoniana, apresentando resultados diferentes em sua pesquisa.

\subsubsection{TOMOGRAFIA COMPUTADORIZADA}

Em 1939, PETRILLI e GURLEY ${ }^{93}$ foram os primeiros a descrever um método radiográfico denominado por eles de tomografia. Em 1943, KURZ ${ }^{63}$ associou o cefalostato à tomografia para obter secções de raios-x da ATM. KURZ seguido por BRADER ${ }^{19}$, que em 1949, utilizou cortes frontais com o propósito de estudar o crescimento.

O princípio da tomografia foi exaustivamente estudado por RICKETTS ${ }^{105}$, em 1962, e parece ser o método mais efetivo de observação do côndilo e das estruturas adjacentes, onde é possível eliminar a superposição de imagens e controlar a densidade óssea ${ }^{109,141}$. 


\subsection{CONCLUSÕES DA REVISÃO DE LITERATURA}

1 - No estudo da assimetria facial, deve ser reconhecido que não há uma face verdadeiramente simétrica em qualquer idade, gênero ou raça. Graus suaves de assimetria facial são comuns na população em geral, sem significância estética ou funcional. A assimetria torna-se importante quando afeta a estética ou a função do paciente.

2 - As causas das assimetrias dentofaciais, geralmente, incluem más formações genéticas ou congênitas, como a microssomia hemifacial; fatores ambientais, como o trauma; desvios funcionais; desvios mandibulares resultantes de interferências dentárias; fatores epigenéticos e adquiridos, como infecções ou patologias. O desenvolvimento da assimetria facial com desvio da linha média e do mento para um lado ocorre quando o crescimento mandibular de um lado aumenta ou diminui, comparando-se com o do lado oposto. Várias causas podem estar relacionadas, podendo a assimetria ser congênita ou adquirida. Como causas da assimetria mandibulares têm sido propostas, incluindo a hiperplasia/hipoplasia condilar, a fratura condilar, a anquilose da ATM, tumor na região da ATM, desordens intra-articulares, assim como desordem interna associada com artrose ou artrite inflamatória e genéticas. $O$ trauma pré-pubescente da mandíbula tem sido indicado como causa da assimetria mandibular, contudo nunca foi comprovado.

3 - Os componentes mais freqüentes que contribuem para a relação ântero-posterior assimétrica na Classe $I$, subdivisão são dentoalveolares, sendo que a principal diferença entre a má oclusão de Classe II, subdivisão e a oclusão normal consiste numa posição mais para distal do primeiro molar inferior do lado da classe II, em uma base óssea com assimetria normal. Uma diferença secundária consiste na posição mais para mesial do primeiro molar superior no lado da classe $\|^{55,56}$.

4 - A maioria dos estudos não encontrou uma assimetria esquelética maior na Classe II, subdivisão em relação à oclusão normal, sendo o principal componente desta má oclusão dentoalveolar.

5 - As radiografias submentonianas e a póstero-anterior são os métodos radiográficos que possibilitam uma melhor avaliação das assimetrias craniofaciais. 
Embora já tenha sido amplamente demonstrado na literatura que a Classe II, subdivisão, não apresenta assimetrias esqueléticas em relação à oclusão normal ${ }^{1,55,56}$, pode-se observar, em muitos casos de Classe II, subdivisão, ligeiras assimetrias faciais em alguns pacientes. Portanto, através deste trabalho investigou-se a correlação entre a assimetria clínica e a assimetria radiográfica nesse tipo de má oclusão. 
3 Proposição 


\section{PROPOSIÇÃO}

O objetivo principal deste trabalho consiste em avaliar, por meio de análise fotográfica e de radiografias submentonianas e póstero-anteriores, a correlação entre a assimetria clínica e a assimetria radiográfica em pacientes com má oclusão de Classe II, subdivisão. Secundariamente, objetivourse comparar por meio destas radiografias o grau de assimetria dentoesquelética entre pacientes com este tipo de má oclusão e que apresentavam assimetria facial aparente com o grau de assimetria dos indivíduos com oclusão normal. 


\section{Materiale}

Métodos 


\section{MATERIAL E MÉTODOS}

\subsection{MATERIAL}

A amostra consistiu de um grupo experimental com 42 indivíduos apresentando má oclusão de Classe II, subdivisão, selecionados dentre aqueles que procuraram tratamento ortodôntico na Disciplina de Ortodontia da Faculdade de Odontologia de Bauru - USP. Destes, 22 eram do gênero masculino e 20 do feminino, com idade média de 15,21 anos.

A figura 1 ilustra um caso de Classe II, subdivisão.

Os indivíduos selecionados do grupo experimental deveriam apresentar as seguintes características:

- má oclusão de Classe II, subdivisão com relação de Classe I de um lado e Classe II completa do outro ${ }^{26,55}$;

- deveriam apresentar todos os dentes permanentes superiores e inferiores, em ambos os arcos dentário, até os primeiros molares $^{1,6,55,107,117}$;

- ausência de tratamento ortodôntico prévio 6,26,55,107;

- ausência de deslocamento mandibular lateral durante o fechamento bucal, detectado durante 0 exame clínico 1,6,26,55, 107,114,117;

- ausência de histórico de trauma facial, ou condições médicas que poderiam ter alterado 0 crescimento das bases apicais $^{6,26,55,100,107}$; e

- apinhamento de no máximo, 3mm nos arcos dentários superior e/ou inferior, desde que simétrico ${ }^{26,55}$.

Utilizou-se, também, um grupo controle de 30 indivíduos com oclusão normal, selecionados dentre estudantes e funcionários desta mesma instituição, que se dispuseram a participar do estudo. Sendo 10 do gênero masculino e 20 do feminino, com idade média de 22,42 anos (TABELA 1).

Como critério básico para a seleção do grupo com oclusão normal, os pacientes deveriam apresentar todos os dentes permanentes superiores e inferiores, em ambos os arcos dentários, até os primeiros 
molares $^{1,6,55,107,117}$ e não terem sido tratados ortodonticamente. A figura 2 ilustra um caso de oclusão normal.

A presença destes critérios foi avaliada, pela examinadora, por meio de exame clínico e anamnese.

Vinte e nove pacientes do grupo experimental já haviam sido selecionados e comparados em pesquisas realizadas anteriormente ${ }^{26,55}$. 

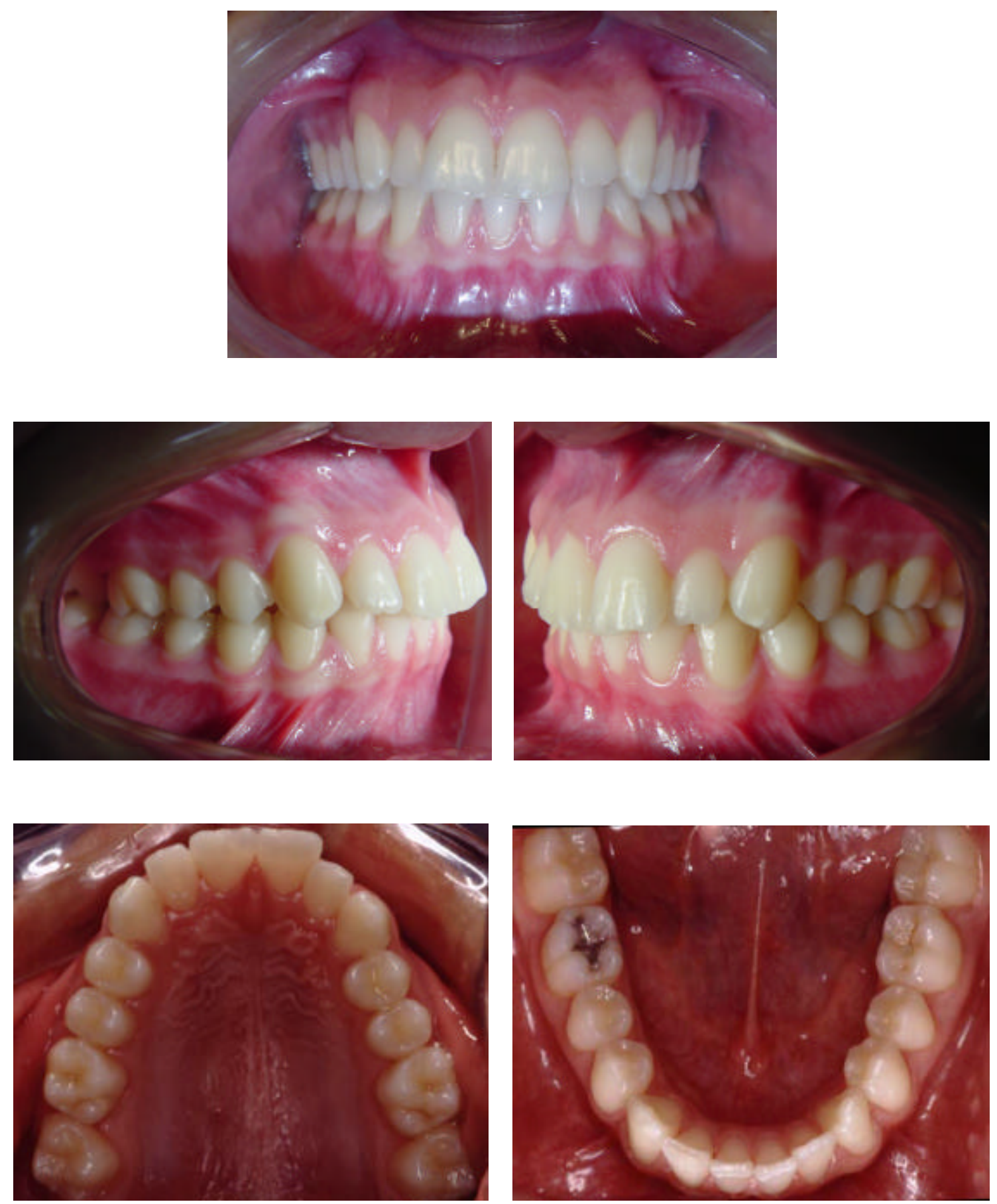

FIGURA 1 - Caso com Classe II, subdivisão 

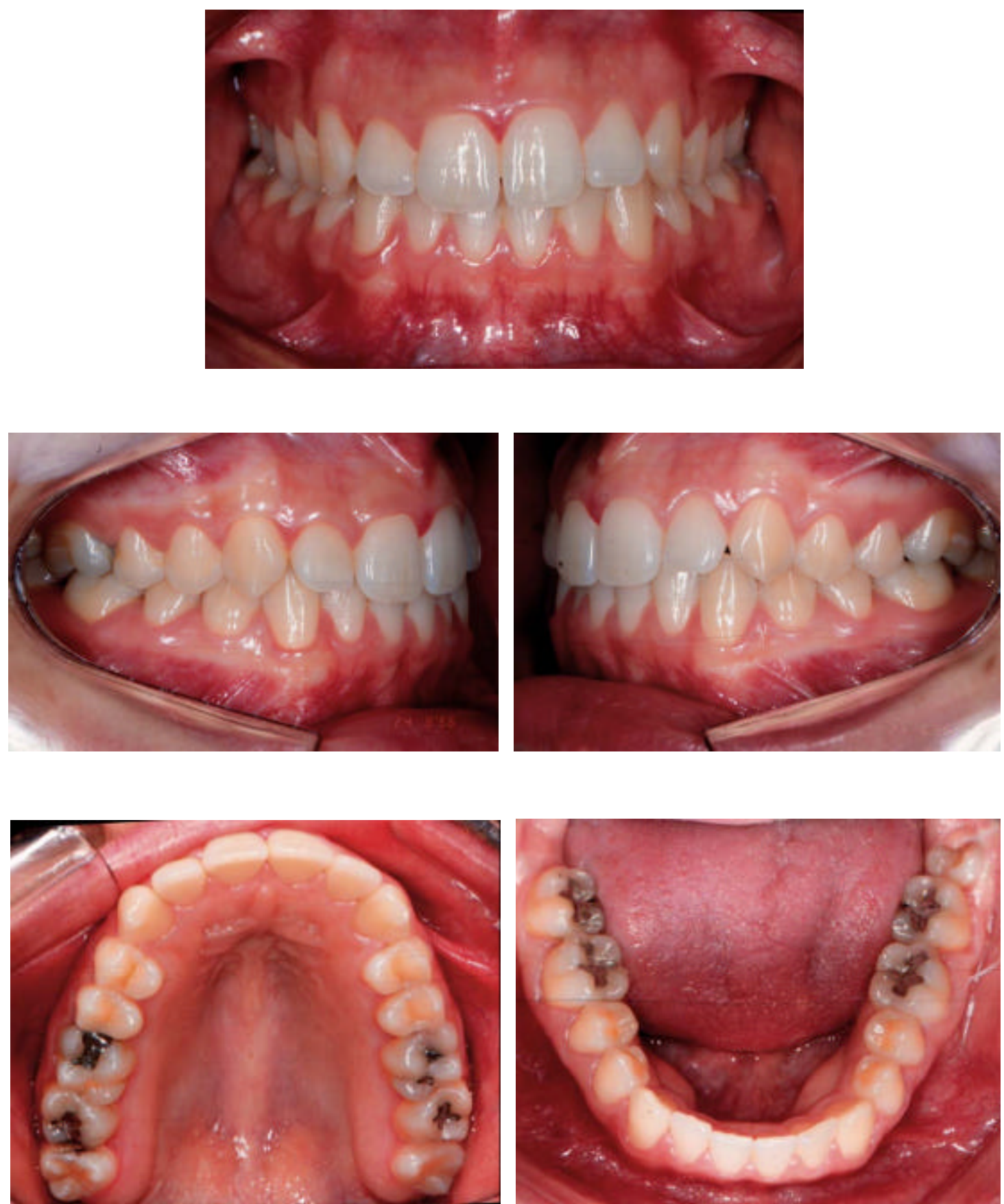

FIGURA 2 - CASO DE OCLUSÃO NORMAL 


\subsection{MÉTODOS}

Foram obtidas duas fotografias frontais (uma sorrindo e uma com os lábios relaxados) e duas radiografias: uma submentoniana e uma pósteroanterior de cada indivíduo. As fotografias, as radiografias e o seu processamento automático, foram realizadas pela investigadora.

\subsubsection{ANÁLISE FOTOGRÁFICA FRONTAL (FIGURA 3)}

Para obtenção da fotografia frontal o paciente foi instruído a sentar-se na posição ereta, olhando para frente na linha do horizonte ${ }^{34}$, com o Plano de Frankfürt paralelo ao solo, oclusão habitual e postura labial relaxada, a fim de que os dados fossem coletados adequadamente ${ }^{7,16,17,126}$.

As fotografias de 29 indivíduos, que já haviam sido utilizados em outros estudos ${ }^{26,55}$, foram obtidas com uma câmera Nikon F801, enquanto que as fotografias de 13 indivíduos foram obtidas com uma câmera digital Sony Cyber-shot DSC F505V. As fotografias obtidas com a câmera manual foram scaneadas em um Scanner Genius Color Page HR6-V2 e todas foram impressas em uma impressora jato de tinta HP Deskjet $840 \mathrm{C}$, onde foram demarcados 08 pontos para cada fotografia frontal.

Para a demarcação dos pontos e linhas e medição das grandezas, foi utilizada a análise de BISHARA, JORGENSEN e JAKOBSEN $^{16,17}$, com algumas modificações de interesse para o estudo.

\subsubsection{PONTOS DE REFERÊNCIA (FIGURA 4)}

1 - Glabela;

2 - Subnasal;

3 - Mento;

4 - Zygion direito;

5 - Zygion esquerdo;

6 - Gônio direito;

7 - Gônio esquerdo; 
8 - Ponto de referência vertical (ponto auxiliar para demarcação da linha mediana da face, demarcada verticalmente desde a glabela e perpendicular ao solo, até abaixo do mento, para possibilitar o traçado da linha no computador).

\subsubsection{LINHAS (FIGURA 5)}

A - Linha mediana da face: linha perpendicular ao solo, passando pela Glabela.

\subsubsection{MEDIDAS LINEARES (FIGURA 6)}

Para obtenção das medidas lineares bilaterais, a medição foi realizada da estrutura em questão até à linha mediana da face ou à estrutura correspondente.

B - Subnasal (Sbn) - distância horizontal entre o subnasal e a linha mediana da face.

C - Mento (Me) - distância horizontal entre o mento e a linha mediana da face.

D - Zygion direito ao mento (ZyD-Me) - distância entre o zygion direito e o mento.

E - Zygion esquerdo ao mento (ZyE-Me) - distância entre o zygion esquerdo e o mento.

F - Gônio direito ao mento (GoD-Me) - distância entre o gônio direito e o mento.

G - Gônio esquerdo ao mento (GoE-Me) - distância entre o gônio esquerdo e o mento.

H - Zygion direito ao Gônio direito (ZyD-GoD) - distância entre o zygion direito e o gônio direito.

I - Zygion esquerdo ao Gônio esquerdo (ZyE-GoE) - distância entre o zygion esquerdo e o gônio esquerdo. 


\subsection{PROPORÇÃO ENTRE AS MEDIDAS BILATERAIS}

Foi realizada a proporção entre as medidas bilaterais da fotografia frontal, pois não houve uma padronização quando da obtenção das mesmas. Portanto, para eliminar qualquer possibilidade de mascarar a verdadeira assimetria entre um lado e outro da face, optourse por utilizar a proporção entre um lado e outro da face.

J - Proporção entre a distância ZyD-Me e ZyE-Me (ZyDMe/ZyEMe).

L - Proporção entre a distância GoD-Me e GoE-Me (GoDMe/GoEMe).

$M$ - Proporção entre a distância ZyD-GoD e ZyE-GoE (ZyDGoD/ZyEGoE). 


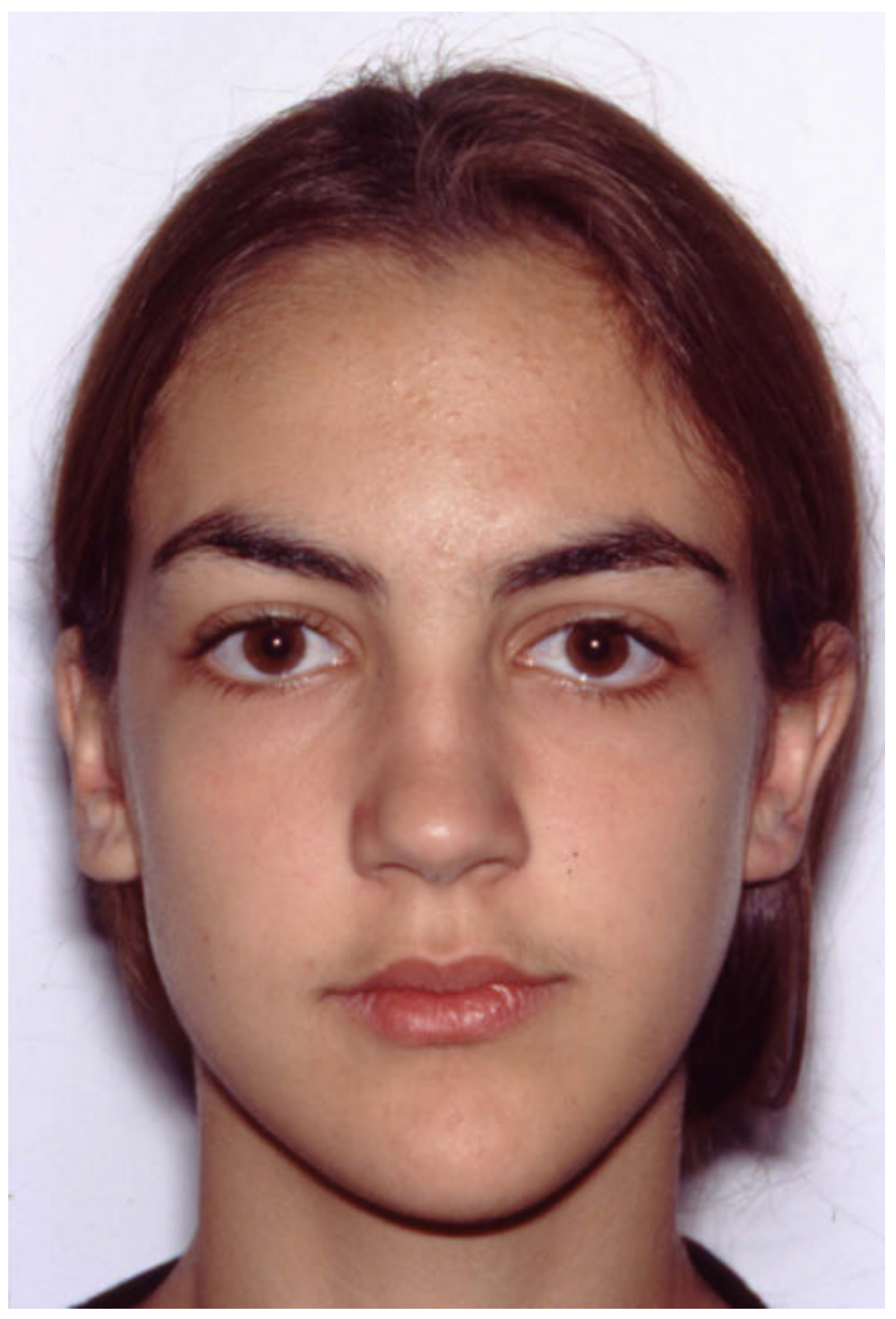

FIGURA 3 - Fotografia Frontal 


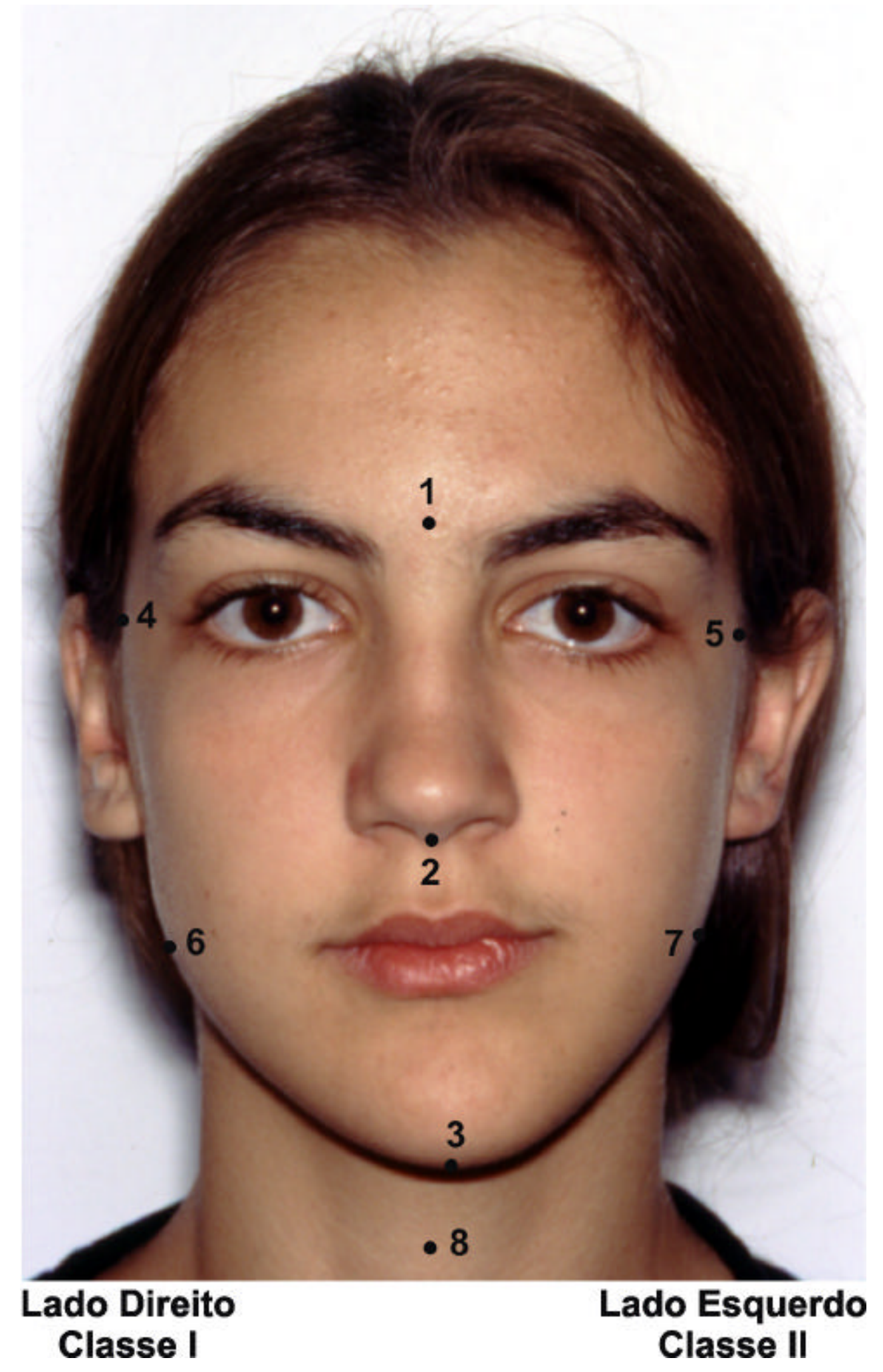

FIGURA 4 - Pontos da fotografia frontal 


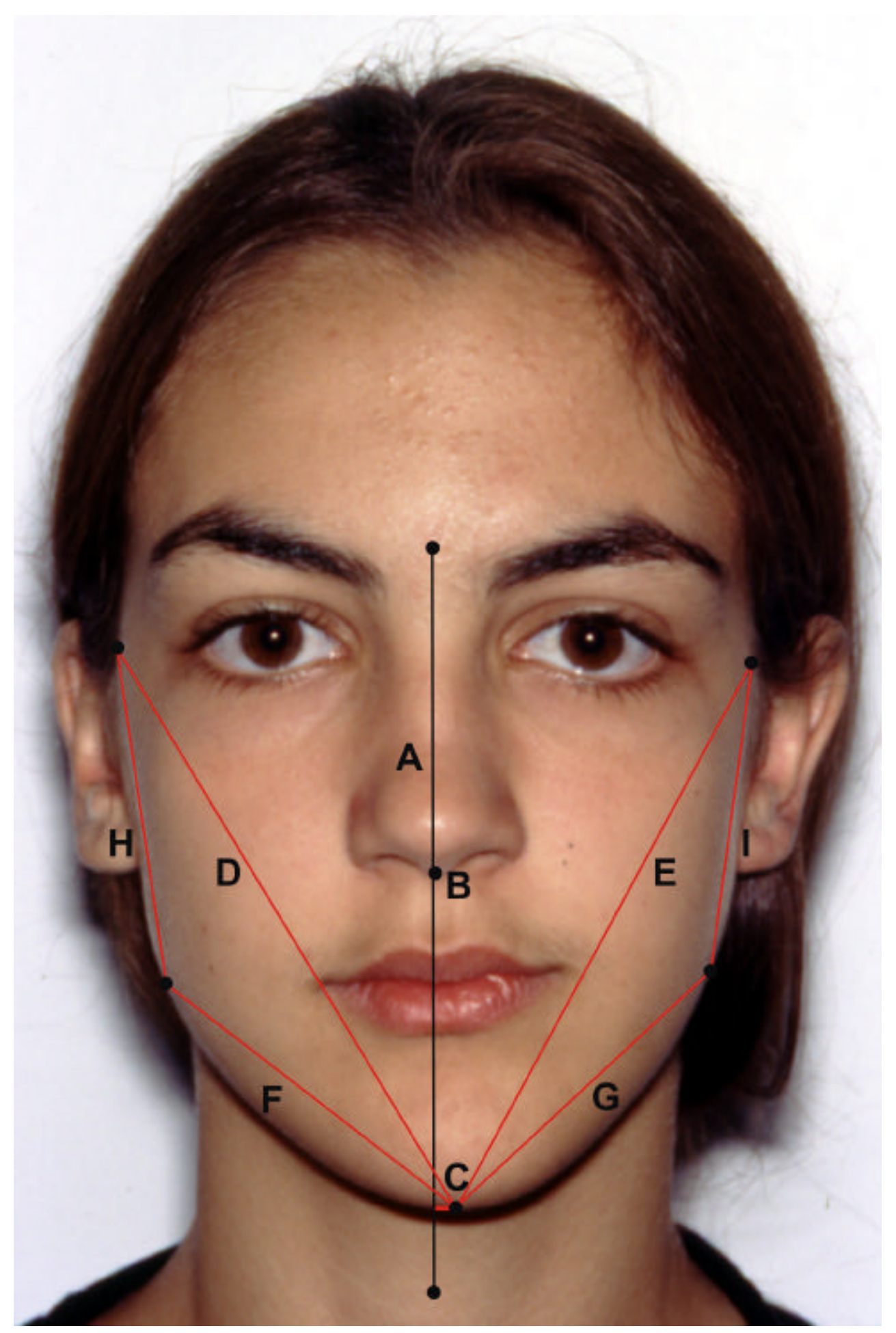

FIGURA 5 - Linha mediana da face e medidas na fotografia frontal 


\subsubsection{RADIOGRAFIA SUBMENTONIANA}

A radiografia submentoniana foi obtida utilizando-se a seguinte técnica $37,44,68,86$ : cada indivíduo foi posicionado em um cefalostato e sentado em um banco sem encosto. A cabeça foi rotada posteriormente, até que o plano de Frankfurt se apresentasse paralelo ao chassis. Com a finalidade de manter essa posição reclinada, o jovem deveria segurar, com as duas mãos, em uma mesa de apoio fixa, posicionada à sua frente. $O$ aparelho utilizado para a radiografia foi o TUR $D 800^{\circ}$, com filme Kodak X-Omat $K$ (não interfoliado) e com tempo de exposição de 0,125s, a $70 \mathrm{kv}$ e $32 \mathrm{ma}$. A distância do ponto focal até às olivas metálicas foi padronizada em $152 \mathrm{~cm}$ e a distância das olivas metálicas até o filme, fixada em $16 \mathrm{~cm}$, o que fornece um fator de magnificação de $9,55 \%$. Durante toda tomada radiográfica os indivíduos deveriam manter os dentes em máxima intercuspidação habitual, sob ligeira pressão.

Para o traçado das estruturas anatômicas de interesse, demarcação dos pontos e linhas e medição das grandezas cefalométricas, foi utilizada a análise de RITUCCI e BURSTONE ${ }^{106}$, com algumas modificações de interesse para o estudo $26,55,56$.

\subsubsection{ESTRUTURAS ANATÔMICAS (FIGURA 6)}

1 - Forame Magno;

2 - Forames espinhosos;

3 - Olivas metálicas;

4 - Mandíbula (incluindo: côndilos, ângulos goníacos e processo coronóides);

5 - Abóbada craniana posterior;

6 - Arcos zigomáticos;

7 - Abóbada craniana anterior;

8 - Fissuras pterigomaxilares;

9 - Vômer;

\footnotetext{
${ }^{\mathrm{c}}$ Dresden, Alemanha (VEB Transformatoren - und Röntgenwerk < Hermann Matern >)
} 
10 - Primeiros molares superiores;

11 - Primeiros molares inferiores;

12 - Incisivos centrais superiores;

13 - Incisivos centrais inferiores.

\subsubsection{PONTOS DE REFERÊNCIA (FIGURA 7)}

1- O centro medial da oliva metálica direita

2- O centro medial da oliva metálica esquerda

3- Gônio direito (GOD) - Ponto médio mediolateralmente na borda posterior do ângulo goníaco direito.

4- Gônio esquerdo (GOE) - Ponto médio mediolateralmente na borda posterior do ângulo goníaco esquerdo.

5- $\quad$ Ponto condilar médio direito (PCMD) - Ponto médio de uma linha que conecta os pontos medial e lateral da cabeça condilar direita.

6- Ponto condilar médio esquerdo (PCME) - Ponto médio de uma linha que conecta os pontos medial e lateral da cabeça condilar esquerda.

7- $\quad$ Ponto condilar medial dreito (PCOMD) - O ponto onde uma linha traçada paralelamente ao corpo mandibular toca a porção medial do côndilo direito.

8- $\quad$ Ponto condilar medial esquerdo (PCOME) - O ponto onde uma linha traçada paralelamente ao corpo mandibular toca a porção medial do côndilo esquerdo.

9- Ponto condilar lateral direito (PCLD) - O ponto onde uma linha traçada paralelamente ao corpo mandibular toca a porção lateral do côndilo direito.

10- Ponto condilar lateral esquerdo (PCLE) - O ponto onde uma linha traçada paralelamente ao corpo mandibular toca a porção lateral do côndilo esquerdo.

11- Distal do primeiro molar inferior direito (DPMID) - O ponto mais distal, alinhado com o sulco mesiodistal central do primeiro molar inferior direito. 
12- Distal do primeiro molar inferior esquerdo (DPMIE) - O ponto mais distal, alinhado com o sulco mesiodistal central do primeiro molar inferior esquerdo.

13- Processo coronóide direito (PCD) - O ponto mais anterior, em relação à linha condilar, no processo coronóide direito.

14- Processo coronóide esquerdo (PCE) - $O$ ponto mais anterior, em relação à linha condilar, no processo coronóide esquerdo.

15- Linha média mandibular (LMM) - O ponto mais anterior do corpo da mandíbula. Este é um ponto esquelético.

16- Linha média dentária inferior (LMDI) - O ponto de contato entre as superfícies mesiais das coroas dos incisivos centrais inferiores.

17- Forame espinhoso direito (FED) - O centro geométrico do forame espinhoso direito.

18- Forame espinhoso esquerdo (FEE) - $O$ centro geométrico do forame espinhoso esquerdo.

19- Linha média dentária superior (LMDS) - O ponto de contato entre as superfícies mesiais das coroas dos incisivos centrais superiores.

20- Vômer anterior (VA) - Intersecção do vômer com uma linha que conecta os pontos angulares direito e esquerdo.

21- Vômer posterior (VP) - Intersecção do vômer com uma linha que conecta os pontos das fissuras pterigomaxilar (PTM) direita e esquerda.

22- Angulare Direito $(A D)^{13,14}$ - Ponto mais anterior, em relação à linha PTM, das opacidades triangulares presentes no ângulo orbital externo, onde as bordas superior e inferior da órbita se encontram e onde o arco zigomático se insere.

23- Angulare Esquerdo $(A E)^{13,14}$ - Ponto mais anterior, em relação à linha PTM, das opacidades triangulares presentes no ângulo orbital externo, onde as bordas 
superior e inferior da órbita se encontram e onde 0 arco zigomático se insere.

24- Buccale Direito (BD) $)^{13,14}$ - Ponto na superfície interna do arco zigomático direito, onde 0 mesmo se curva mesialmente e, em seguida, para trás.

25- Buccale Esquerdo $(B E)^{13,14}$ - Ponto na superfície interna do arco zigomático esquerdo, onde o mesmo se curva mesialmente e, em seguida, para trás.

26- Fossa craniana média direita (FCMD) - Ponto mais anterior, em relação à linha interespinhosos, na asa menor do osso esfenóide.

27- Fossa craniana média esquerda (FCME) - Ponto mais anterior, em relação à linha interespinhosos, na asa menor do osso esfenóide.

28- Fissura pterigomaxilar direita (FPTMD) - Ponto mais medial e posterior da fissura pterigomaxilar direita. A linha PTM conecta os pontos PTMD e PTME.

29- Fissura pterigomaxilar esquerda (FPTME) - Ponto mais medial e posterior da fissura pterigomaxilar esquerda.

30- Zygion direito (ZD) - Ponto localizado na intersecção da borda lateral do arco zigomático direito, obtido pelo prolongamento da linha PTM e traçado pela secção de maior largura da distância bizigomática.

31- Zygion esquerdo (ZE) - Ponto localizado na intersecção da borda lateral do arco zigomático esquerdo, obtido pelo prolongamento da linha PTM e traçado pela secção de maior largura da distância bizigomática.

32- Abóbada craniana anterior direita (ACAD) - Ponto onde a borda lateral do crânio é interceptada por uma linha que conecta os pontos zygion direito e esquerdo.

33- Abóbada craniana anterior esquerda (ACAE) - Ponto onde a borda lateral do crânio é interceptada por uma linha que conecta os pontos zygion direito e esquerdo. 
34- Básio $(\mathrm{Ba})$ - Ponto mais anterior, em relação à linha interespinhosos, na borda anterior do forame magno.

35- Opístion $(\mathrm{Op})$ - Ponto mais posterior, em relação à linha interespinhosos, na borda posterior do forame magno.

36- Abóbada craniana posterior direita (ACPD) - Ponto onde a borda lateral direita da abóbada craniana é interceptada por uma linha paralela à linha interespinhosos, traçada pela abóbada craniana, em sua secção de maior largura.

37- Abóbada craniana posterior esquerda (ACPE) - Ponto onde a borda lateral esquerda da abóbada craniana é interceptada por uma linha paralela à linha interespinhosos, traçada pela abóbada craniana, em sua secção de maior largura.

38- Contorno médio da mandíbula do lado direito (CMMD) Ponto mais medial e posterior, no contorno médio do corpo da mandíbula, do lado direito.

39- Contorno médio da mandíbula do lado esquerdo (CMME) Ponto mais medial e posterior, no contorno médio do corpo da mandíbula, do lado esquerdo.

40- Ponto médio do eixo transespinhosos (PMETE) - Ponto médio na linha que une o centro geométrico dos pontos dos forames espinhosos.

41- Ponto perpendicular ao eixo transespinhosos (PERPETE) - Ponto demarcado perpendicularmente ao eixo transforame espinhoso, à frente do mento, eqüidistante dos forames espinhosos (este e os outros pontos perpendiculares aos eixos das abscissas foram utilizados apenas para possibilitar o traçado dos eixos das ordenadas).

42- Ponto perpendicular ao eixo transcondilar (PERPETC) Um ponto demarcado perpendicularmente ao eixo transcondilar, à frente do mento, eqüidistante dos pontos médios condilares. 
43- Ponto médio do eixo transcondilar (PMETC) - Ponto médio entre os dois pontos condilares médios, no eixo transcondilar.

44- Ponto médio do eixo transpterigomaxilar (PMETPTM) - O ponto médio entre os dois pontos FPTM (fissura pterigomaxilar, direita e esquerda), no eixo transpterigomaxilar.

45- Ponto perpendicular ao eixo transpterigomaxilar (PERPETPTM) - Um ponto demarcado perpendicularmente ao eixo transpterigomaxilar, à frente do mento, eqüidistante dos pontos FPTM.

46- Ponto médio do eixo transmolar (PMETM) - Ponto médio entre os dois pontos DPMI (distal do primeiro molar inferior direito e esquerdo), no eixo transmolar.

47- Ponto perpendicular ao eixo transmolar (PERPETM) - Um ponto demarcado perpendicularmente ao eixo transmolar, à frente do mento, eqüidistantes dos pontos DPMID e DPMIE.

48- Centro da face vestibular do primeiro molar inferior direito (CVPMID).

49- Centro da face vestibular do primeiro molar inferior esquerdo (CVPMIE).

50- Borda mandibular direita (BMD) - Ponto onde a linha perpendicular à face vestibular do primeiro molar inferior direito intercepta a borda mandibular.

51- Borda mandibular esquerda (BME) - Ponto onde a linha perpendicular à face vestibular do primeiro molar inferior esquerdo intercepta a borda mandibular.

52- $\quad$ Ponto na distal do primeiro molar superior direito (DPMSD) - Ponto mais distal, alinhado com o sulco principal do primeiro molar superior direito.

53- Ponto na distal do primeiro molar superior esquerdo (DPMSE) - Ponto mais distal, alinhado com o sulco principal do primeiro molar superior esquerdo. 
54- Centro da face vestibular do primeiro molar superior direito (CVPMSD).

55- Centro da face vestibular do primeiro molar superior esquerdo (CVPMSE).

56- Borda mandibular superior direita (BMSD) - Ponto onde a perpendicular à face vestibular do primeiro molar superior direito intercepta a borda mandibular.

57- Borda mandibular superior esquerda (BMSE) - Ponto onde a perpendicular à face vestibular do primeiro molar superior esquerdo intercepta a borda mandibular.

58- Ponto médio do eixo transmolar superior (PMETMS) Ponto médio entre os dois pontos nas distais dos primeiros molares superiores direito e esquerdo no eixo transmolar superior.

59- Ponto perpendicular ao eixo transmolar superior (PERPETMS) - Ponto demarcado perpendicularmente ao eixo transmolar superior, à frente do mento, eqüidistantes dos pontos DPMSD e DPMSE. 


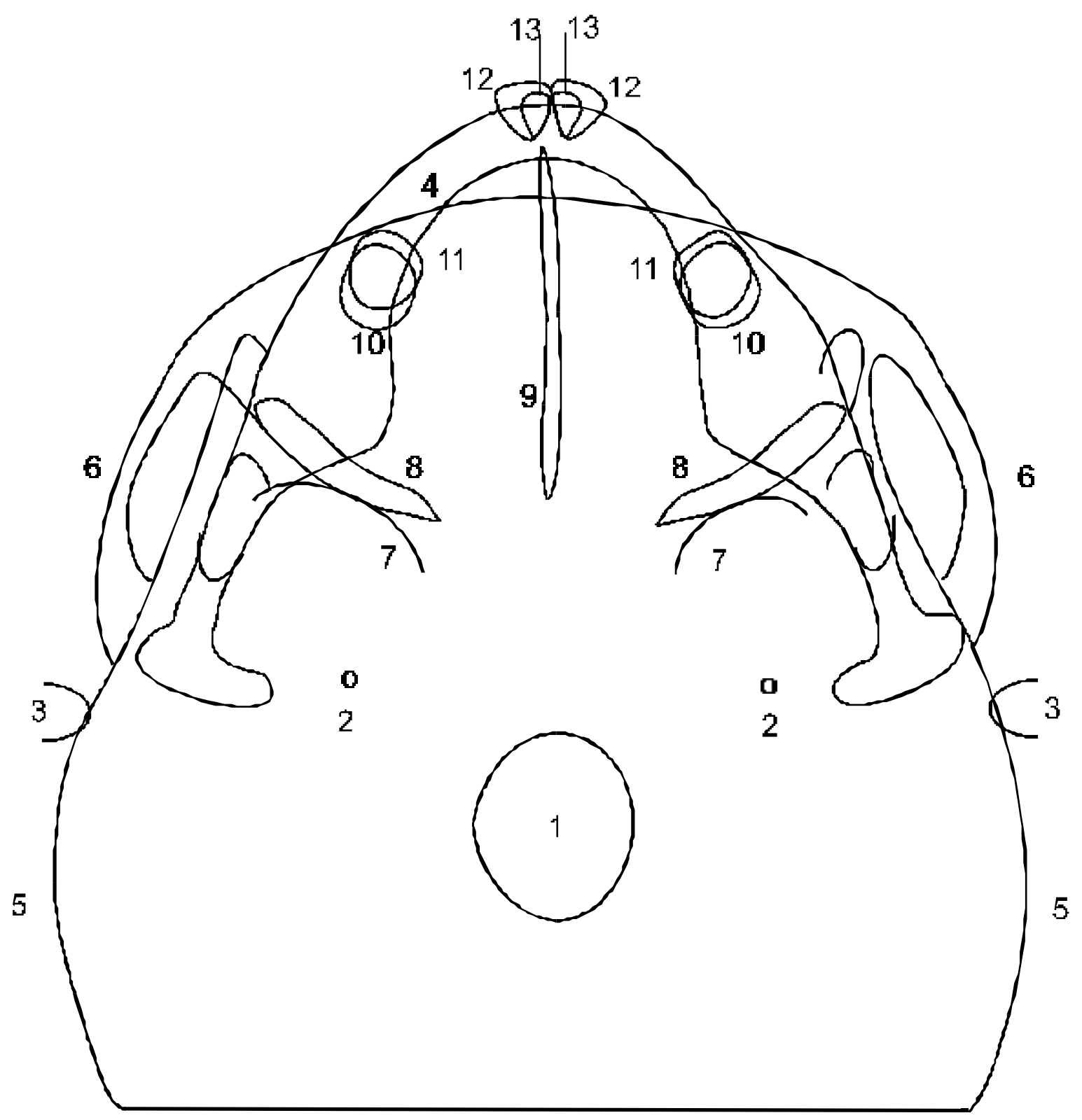

FIGURA 6 - Estruturas anatômicas da radiografia submentoniana

\footnotetext{
${ }^{*}$ FONTE: Figura reproduzida da pesquisa de JANSON ${ }^{56}$
} 


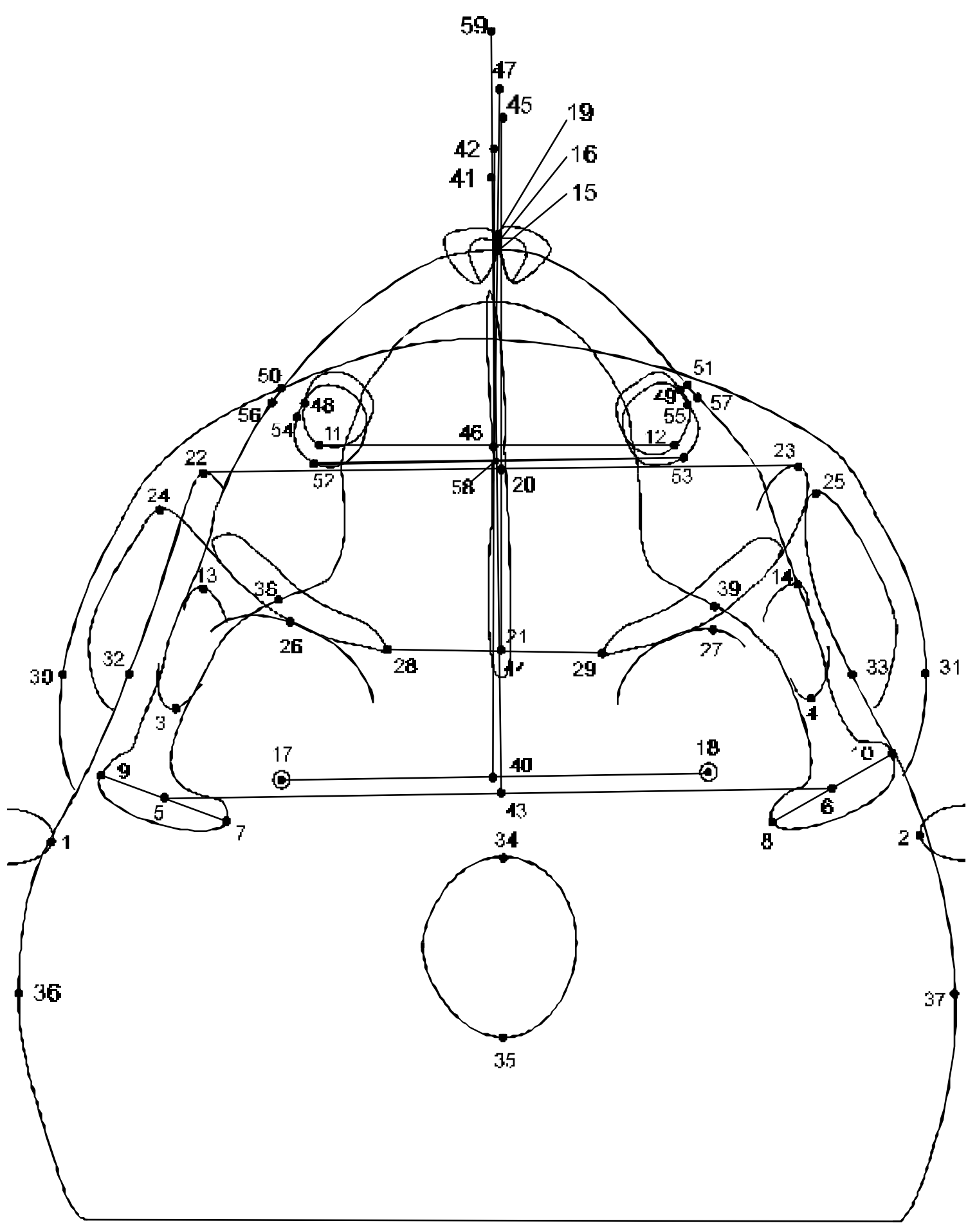

FIGURA 7 - Pontos da radiografia submentoniana*

\footnotetext{
${ }^{*}$ FONTE: Figura reproduzida da pesquisa de $\mathrm{JANSON}^{56}$.
} 


\subsubsection{LINHAS (FIGURA 8)}

A - Eixo Transcondilar - ETC - linha que passa pelos pontos PCMD e PCME, 5-6.

B - Eixo Transespinhosos - ETE - linha que passa pelos pontos FED e FEE, 17-18.

C - Eixo Transpterigomaxilar - ETPTM - linha que passa pelos pontos FPTMD e FPTME, 28-29.

D - Eixo Transmolares Inferiores - ETMI - linha que passa pelos pontos DPMID e DPMIE, 11-12.

E - Eixo Transmolares Superiores - ETMS - linha que passa pelos pontos DPMSD e DPMSE, 52-53.

F - Eixo Intercondilar - EIC - linha perpendicular ao eixo transcondilar, passando pelo ponto médio do mesmo, 42-43.

G - Eixo Interespinhosos - EIE - linha perpendicular ao eixo transespinhosos, passando pelo ponto médio do mesmo, 40-41.

$\mathrm{H}$ - Eixo Interpterigomaxilar - EIPTM - linha perpendicular ao eixo transpterigomaxilar, passando pelo ponto médio do mesmo, 44-45.

I - Eixo Intermolares Inferiores - EIMI - linha perpendicular ao eixo transmolar inferior, passando pelo ponto médio do mesmo, 46-47.

$\mathrm{J}$ - Eixo Intermolares Superiores - EIMS - linha perpendicular ao eixo transmolar superior, passando pelo ponto médio do mesmo, 58-59. 


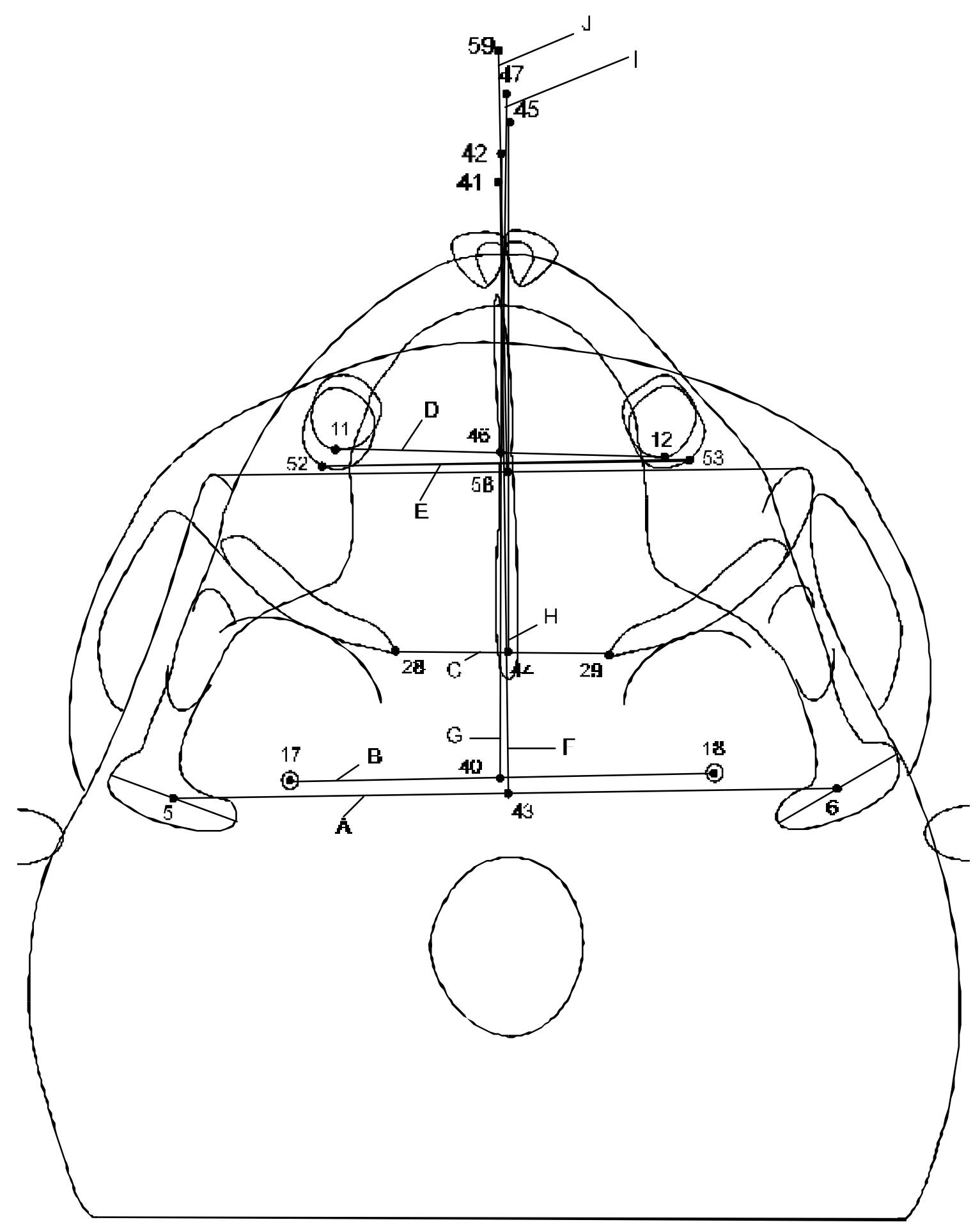

FIGURA 8 - Linhas da radiografia submentoniana

\footnotetext{
${ }^{*}$ FONTE: Figura reproduzida da pesquisa de $\mathrm{JANSON}^{56}$.
} 


\subsubsection{GRANDEZAS CEFALOMÉTRICAS}

Neste estudo foi utilizado o método proposto por RITUCCI e BURSTONE ${ }^{106}$, com algumas modificações, que consiste em avaliar a assimetria das estruturas craniodentárias em relação aos diferentes sistemas de coordenadas. Os sistemas de coordenadas utilizados foram: o sistema de coordenadas mandibulares, do assoalho craniano, zigomaticomaxilar, dentários e, também, as medidas angulares entre as abscissas dos sistemas de coordenadas e algumas variáveis adicionais.

Nos sistemas de coordenadas (FIGURAS 9 a 15) foram estabelecidos dois eixos perpendiculares entre si, para a avaliação da posição ântero-posterior e transversal das estruturas, em relação a estes eixos. Desta forma, no sistema de coordenadas mandibulares, estabeleceu-se o eixo transcondilar, passando pelo ponto médio condilar e servindo na avaliação da simetria da posição ântero-posterior das estruturas mandibulares, e o eixo intercondilar, perpendicular ao eixo transcondilar, a partir do ponto médio deste último, para a avaliação da simetria da posição transversal destas estruturas. De maneira análoga, foram construídos os eixos transespinhosos e interespinhosos, para o sistema de coordenadas do assoalho craniano; os eixos transpteriogomaxilar e interpterigomaxilar, para o sistema de coordenadas zigomaticomaxilares e os eixos transmolares e intermolares superiores e inferiores, para o sistema de coordenadas dentárias. Após a obtenção das grandezas para as variáveis dos lados direito e esquerdo, obteve-se a diferença entre elas, sendo todas as variáveis descriminadas a seguir.

Em consonância com a metodologia adotada por JANSON ${ }^{55,56}$, as radiografias submentonianas e póstero-anteriores, bem como as fotografias, foram posicionadas de forma que o lado com Classe I estivesse sempre do lado esquerdo do observador, considerando que o profissional se encontrava posicionado à frente do paciente. Este procedimento foi adotado, para que o programa de cefalometria calculasse as diferenças entre as medidas bilaterais subtraindo sempre os valores do lado esquerdo, do caso em questão, dos valores do lado direito. Os desvios de estruturas centrais, na radiografia submentoniana, foram calculados de forma que um valor positivo era atribuído 
se a estrutura estivesse localizada à direita (esquerda do observador) do eixo sagital e um valor negativo, se a estrutura estivesse à esquerda. Na radiografia póstero-anterior, assim como na fotografia, adotourse o critério contrário, por motivos técnicos do programa de cefalometria.

Foram utilizados valores absolutos para as diferenças entre as medidas dos lados direito e esquerdo e para as distâncias horizontais aos planos de referência médios. Desta forma, eliminourse a possibilidade de valores de diferença positivos e negativos se cancelarem no cálculo das médias para cada grupo ${ }^{8}$.

O posicionamento das radiografias, da forma anteriormente mencionada, foi realizado para que as leituras dos valores reais não fossem influenciadas, mas para o cálculo dos valores absolutos este protocolo poderia ser dispensado.

\subsection{SISTEMA DE COORDENADAS MANDIBULARES}

\subsection{1 ÂNTERO-POSTERIOR (FIGURA 9)}

1 - Gônio direito ao eixo transcondilar (GOD-ETC).

2 - Gônio esquerdo ao eixo transcondilar (GOE-ETC).

3 - Ponto do processo coronóide direito ao eixo transcondilar (PCD-ETC).

4 - Ponto do processo coronóide esquerdo ao eixo transcondilar (PCE-ETC).

5 - Ponto distal do primeiro molar inferior direito ao eixo transcondilar (PDMID-ETC).

6 - Ponto distal do primeiro molar inferior esquerdo ao eixo transcondilar (PDMIE-ETC).

7 - Ponto distal do primeiro molar superior direito ao eixo transcondilar (PDMSD-ETC).

8 - Ponto distal do primeiro molar superior esquerdo ao eixo transcondilar (PDMSE-ETC). 


\subsection{TRANSVERSO (FIGURA 10)}

9 - Gônio direito ao eixo intercondilar (GOD-EIC).

10 - Gônio esquerdo ao eixo intercondilar (GOE-EIC).

11 - Ponto do processo coronóide direito ao eixo intercondilar (PPCD-EIC).

12 - Ponto do processo coronóide esquerdo ao eixo intercondilar (PPCE-EIC).

13 - Ponto distal do primeiro molar inferior direito ao eixo intercondilar (PDMID-EIC).

14 - Ponto distal do primeiro molar inferior esquerdo ao eixo intercondilar (PDMIE-EIC).

15 - Ponto distal do primeiro molar superior direito ao eixo intercondilar (PDMSD-EIC).

16 - Ponto distal do primeiro molar superior esquerdo ao eixo intercondilar (PDMSE-EIC).

17 - Linha média mandibular ao eixo intercondilar (LMM-EIC).

18 - Linha média dentária inferior ao eixo intercondilar (LMDF EIC).

19 - Linha média dentária superior ao eixo intercondilar (LMDSEIC). 


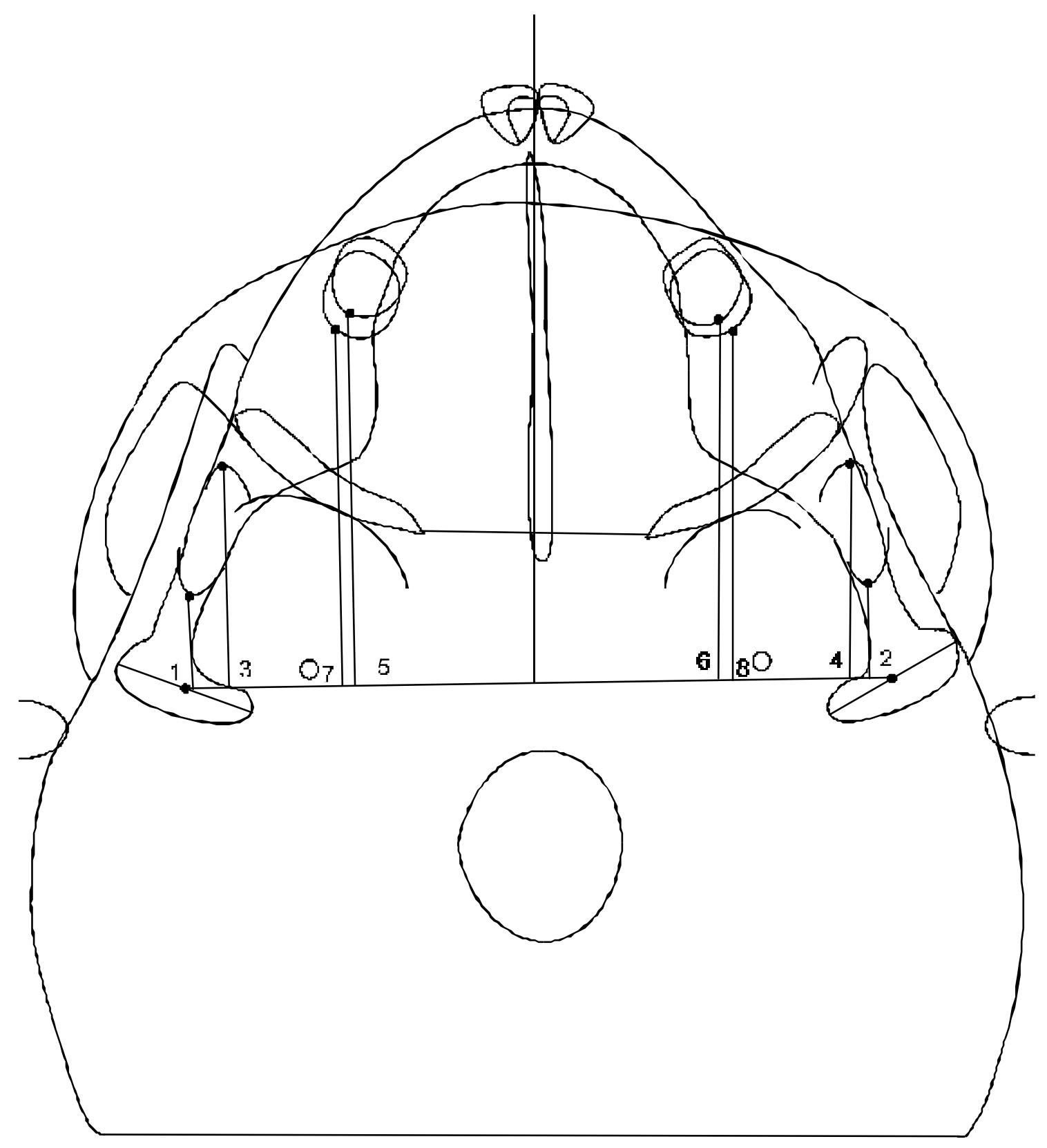

FIGURA 9 - Grandezas cefalométricas da radiografia submentoniana Sistema de Coordenadas Mandibulares - Ântero-Posterior ${ }^{*}$

\footnotetext{
${ }^{*}$ FONTE: Figura reproduzida da pesquisa de $\mathrm{JANSON}^{56}$.
} 


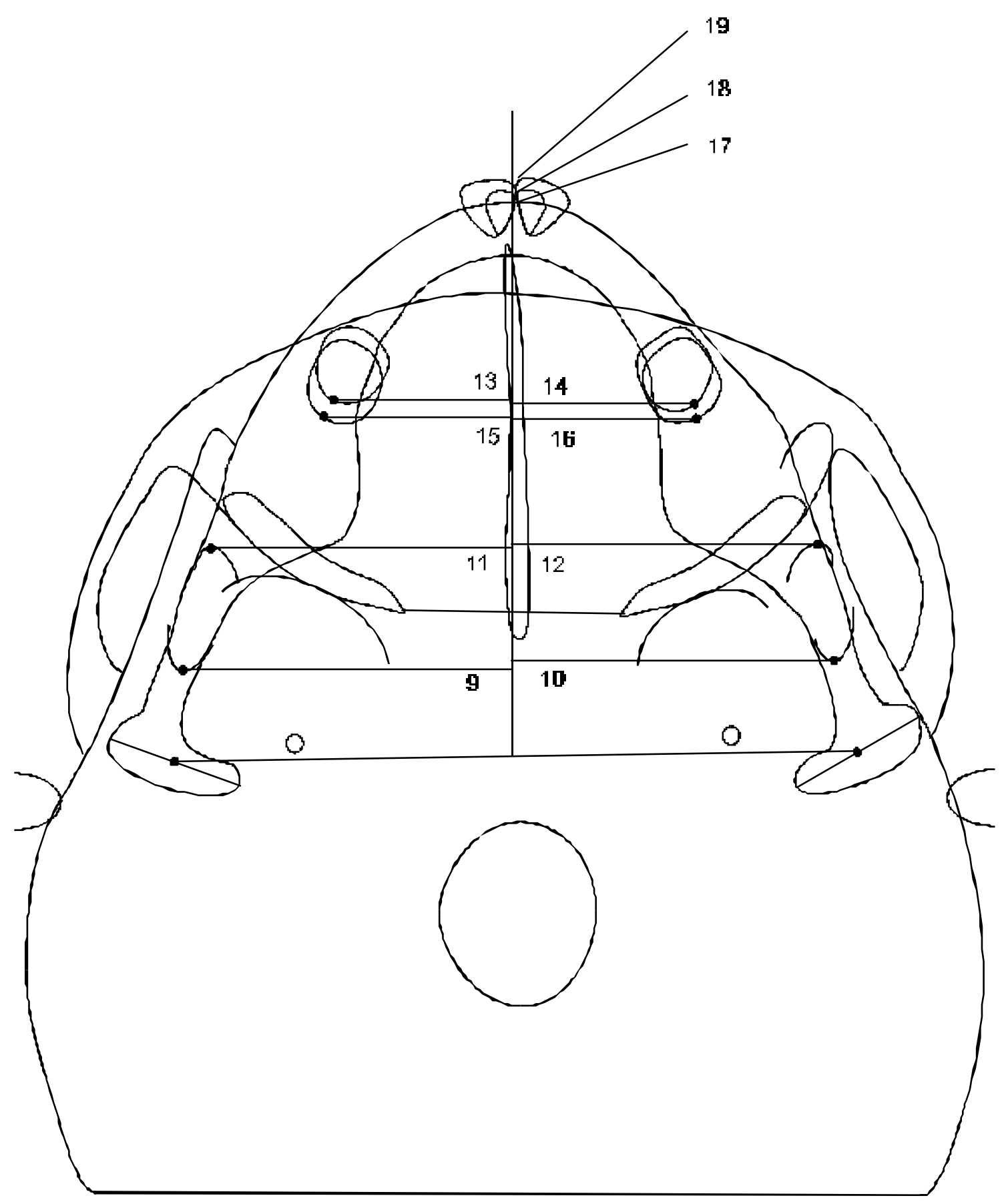

FIGURA 10 - Grandezas cefalométricas da radiografia submentoniana Sistema de Coordenadas Mandibulares - Transverso*

\footnotetext{
${ }^{*}$ FONTE: Figura reproduzida da pesquisa de $\mathrm{JANSON}^{56}$.
} 


\subsection{SISTEMA DE COORDENADAS DO ASSOALHO CRANIANO}

\subsection{1 ÂNTERO-POSTERIOR (FIGURA 11)}

20 - Ponto condilar médio direito ao eixo transespinhosos (PCMD-ETE).

21 - Ponto condilar médio esquerdo ao eixo transespinhosos (PCME-ETE).

22 - Gônio direito ao eixo transespinhosos (GOD-ETE).

23 - Gônio esquerdo ao eixo transespinhosos (GOE-ETE).

24 - Ponto no processo coronóide direito ao eixo transespinhosos (PPCD-ETE).

25 - Ponto no processo coronóide esquerdo ao eixo transespinhosos (PPCE-ETE).

26 - Ponto na distal do primeiro molar inferior direito ao eixo transespinhosos (PDMID-ETE).

27 - Ponto na distal do primeiro molar inferior esquerdo ao eixo transespinhosos (PDMIE-ETE).

28 - Ponto na distal do primeiro molar superior direito ao eixo transespinhosos (PDMSD-ETE).

29 - Ponto na distal do primeiro molar superior esquerdo ao eixo transespinhosos (PDMSE-ETE).

30 - Abóboda craniana posterior direita ao eixo transespinhosos (ACPD-ETE).

31 - Abóboda craniana posterior esquerda ao eixo transespinhosos (ACPE-ETE).

32 - Fossa craniana média direita ao eixo transespinhosos (FCMD-ETE).

33 - Fossa craniana média esquerda ao eixo transespinhosos (FCME-ETE). 


\subsection{TRANSVERSO (FIGURA 12)}

34 - Ponto condilar médio direito ao eixo interespinhosos (PCMD-EIE).

35 - Ponto condilar médio esquerdo ao eixo interespinhosos (PCME-EIE).

36 - Gônio direito ao eixo interespinhosos (GOD-EIE).

37 - Gônio esquerdo ao eixo interespinhosos (GOE-EIE).

38 - Ponto no processo coronóide direito ao eixo interespinhosos (PPCD-EIE).

39 - Ponto no processo coronóide esquerdo ao eixo interespinhosos (PPCE-EIE).

40 - Ponto distal do primeiro molar inferior direito ao eixo interespinhosos (PDMID-EIE).

41 - Ponto distal do primeiro molar inferior esquerdo ao eixo interespinhosos (PDMIE-EIE).

42 - Ponto distal do primeiro molar superior direito ao eixo interespinhosos (PDMSD-EIE).

43 - Ponto distal do primeiro molar superior esquerdo ao eixo interespinhosos (PDMSE-EIE).

44 - Linha média mandibular ao eixo interespinhosos (LMMEIE). (LMDLEIE).

45 - Linha média dentária inferior ao eixo interespinhosos

46 - Linha média dentária superior ao eixo interespinhosos (LMDS-EIE).

47 - Abóboda craniana posterior direita ao eixo interespinhosos (ACPD-EIE).

48 - Abóboda craniana posterior esquerda ao eixo interespinhosos (ACPE-EIE).

49 - Fossa craniana média direita ao eixo interespinhosos (FCMD-EIE).

50 - Fossa craniana média direita ao eixo interespinhosos (FCME-EIE). 
51 - Básio ao eixo interespinhosos (Ba-EIE).

52 - Opístion ao eixo interespinhosos (Op-EIE).

\subsection{SISTEMA DE COORDENADAS DO COMPLEXO ZIGOMÁTICOMAXILAR}

\subsection{1 ÂNTERO-POSTERIOR (FIGURA 13)}

53 - Buccale direito ao eixo transpterigomaxilar (BCD-ETPTM).

54 - Buccale esquerdo ao eixo transpterigomaxilar (BCEETPTM).

55 - Zygion direito ao eixo transpterigomaxilar (ZD-ETPTM).

56 - Zygion esquerdo ao eixo transpterigomaxilar (ZE-ETPTM).

57 - Abóboda craniana anterior direita ao eixo transpterigomaxilar (ACAD-ETPTM).

58 - Abóboda craniana anterior esquerda ao eixo transpterigomaxilar (ACAE-ETPTM).

59 - Angulare direito ao eixo transpterigomaxilar (AD-ETPTM).

60 - Angulare esquerdo ao eixo transpterigomaxilar (AEETPTM).

61 - Ponto distal do primeiro molar inferior direito ao eixo transpterigomaxilar (PDMID-ETPTM).

62 - Ponto distal do primeiro molar inferior esquerdo ao eixo transpterigomaxilar (PDMIE-ETPTM).

63 - Ponto distal do primeiro molar superior direito ao eixo transpterigomaxilar (PDMSD-ETPTM).

64 - Ponto distal do primeiro molar superior esquerdo ao eixo transpterigomaxilar (PDMSE-ETPTM).

\subsection{TRANSVERSO (FIGURA 14)}

65 - Buccale direito ao eixo interpterigomaxilar (BCD-EIPTM). 
66 - Buccale esquerdo ao eixo interpterigomaxilar (BCEEIPTM).

67 - Zygion direito ao eixo interpterigomaxilar (ZD-EIPTM).

68 - Zygion esquerdo ao eixo interpterigomaxilar (ZE-EIPTM).

69 - Abóboda craniana anterior direita ao eixo interpterigomaxilar (ACAD-EIPTM).

70 - Abóboda craniana anterior esquerda ao eixo interpterigomaxilar (ACAE-EIPTM).

71 - Angulare direito ao eixo interpterigomaxilar (AD-EIPTM).

72 - Angulare esquerdo ao eixo interpterigomaxilar (AE-EIPTM)

73 - Ponto vômer anterior ao eixo interpterigomaxilar (PVAEIPTM).

74 - Ponto vômer posterior ao eixo interpterigomaxilar (PVPEIPTM).

75 - Ponto distal do primeiro molar inferior direito ao eixo interpterigomaxilar (PDMID -EIPTM).

76 - Ponto distal do primeiro molar inferior esquerdo ao eixo interpterigomaxilar (PDMIE-EIPTM).

77 - Ponto distal do primeiro molar superior direito ao eixo interpterigomaxilar (PDMSD-EIPTM).

78 - Ponto distal do primeiro molar superior esquerdo ao eixo interpterigomaxilar (PDMSE-EIPTM).

79 - Linha média dentária superior ao eixo interpterigomaxilar (LMDS-EIPTM).

80 - Linha média mandibular ao eixo interpterigomaxilar (LMMEIPTM).

81 - Linha média dentária inferior ao eixo interpterigomaxilar (LMDLEIPTM).

\subsection{SISTEMA DE COORDENADAS DENTÁRIAS (FIGURA 15)}

\subsection{1 ÂNTERO-POSTERIOR}


82 - Ponto na distal do primeiro molar inferior direito ao ponto condilar médio direito (PDMID-PCMD).

83 - Ponto na distal do primeiro molar inferior esquerdo ao ponto condilar médio esquerdo (PDMIE-PCME).

84 - Ponto na distal do primeiro molar superior direito ao ponto condilar médio direito (PDMSD-PCMD).

85 - Ponto na distal do primeiro molar superior esquerdo ao ponto condilar médio esquerdo (PDMSE-PCME).

\subsection{TRANSVERSO}

86 - Linha média dentária inferior ao eixo intermolares (LMDF EIMI).

87 - Linha média mandibular ao eixo intermolares (LMM-EIMI).

88 - Linha média dentária superior ao eixo intermolares (LMDSEIMI).

89 - Linha média dentária inferior ao eixo intermolares superiores (LMDFEIMS).

90 - Linha média dentária superior ao eixo intermolares superiores (LMDS-EIMS).

91 - Linha média mandibular ao eixo intermolares superiores (LMM-EIMS).

\subsection{MEDIDAS ANGULARES ENTRE AS ABSCISSAS DOS SISTEMAS DE COORDENADAS (FIGURA 16)}

92 - Ângulo entre os eixos interespinhosos e intercondilar (EIEEIC).

93 - Ângulo entre o eixo transespinhosos e o eixo transcondilar (ETE-ETC).

94 - Ângulo entre o eixo transpterigomaxilar e o eixo transcondilar (ETPTM-ETC). 
95 - Ângulo entre 0 eixo transpterigomaxilar e 0 eixo transespinhosos (ETPTM-ETE).

96 - Ângulo entre 0 eixo transmolar inferior e o eixo transespinhosos (ETM-ETE).

97 - Ângulo entre 0 eixo transmolar inferior e o eixo transcondilar (ETM-ETC).

98 - Ângulo entre o eixo transmolar inferior e o eixo transpterigomaxilar (ETMI-ETPTM).

99 - Ângulo entre o eixo transmolar superior e o eixo transespinhosos (ETMS-ETE).

100- Ângulo entre o eixo transmolar superior e o eixo transcondilar (ETMS-ETC).

101- Ângulo entre o eixo transmolar superior e o eixo transpterigomaxilar (ETMS-ETPTM). 


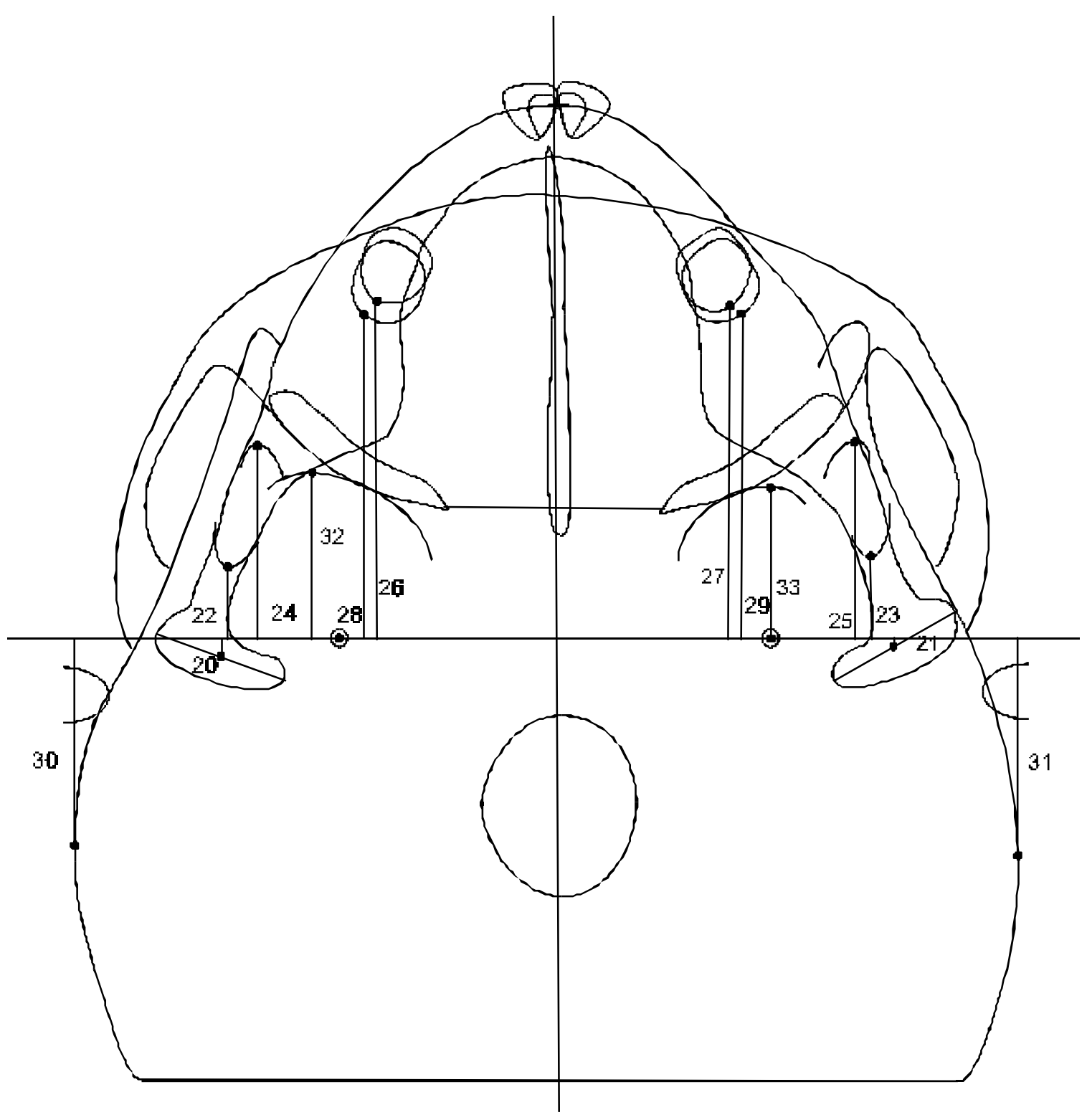

FIGURA 11 - Grandezas cefalométricas da radiografia submentoniana Sistema de Coordenadas do Assoalho Craniano - Ântero-Posterior ${ }^{*}$

\footnotetext{
${ }^{*}$ FONTE: Figura reproduzida da pesquisa de $\mathrm{JANSON}^{56}$.
} 


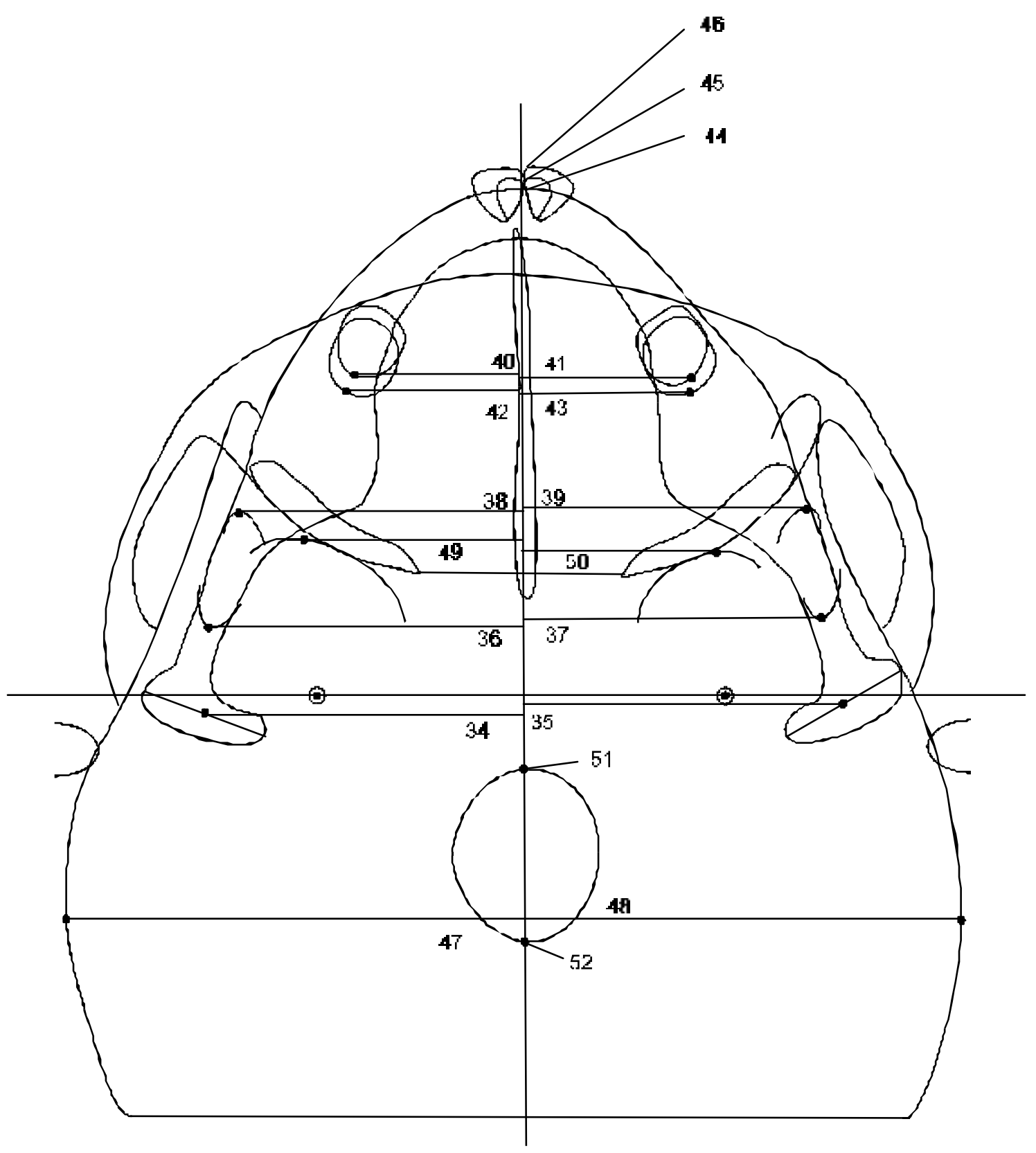

FIGURA 12 - Grandezas cefalométricas da radiografia submentoniana Sistema de Coordenadas do Assoalho Craniano-Transverso*

\footnotetext{
${ }^{*}$ FONTE: Figura reproduzida da pesquisa de $\mathrm{JANSON}^{56}$.
} 


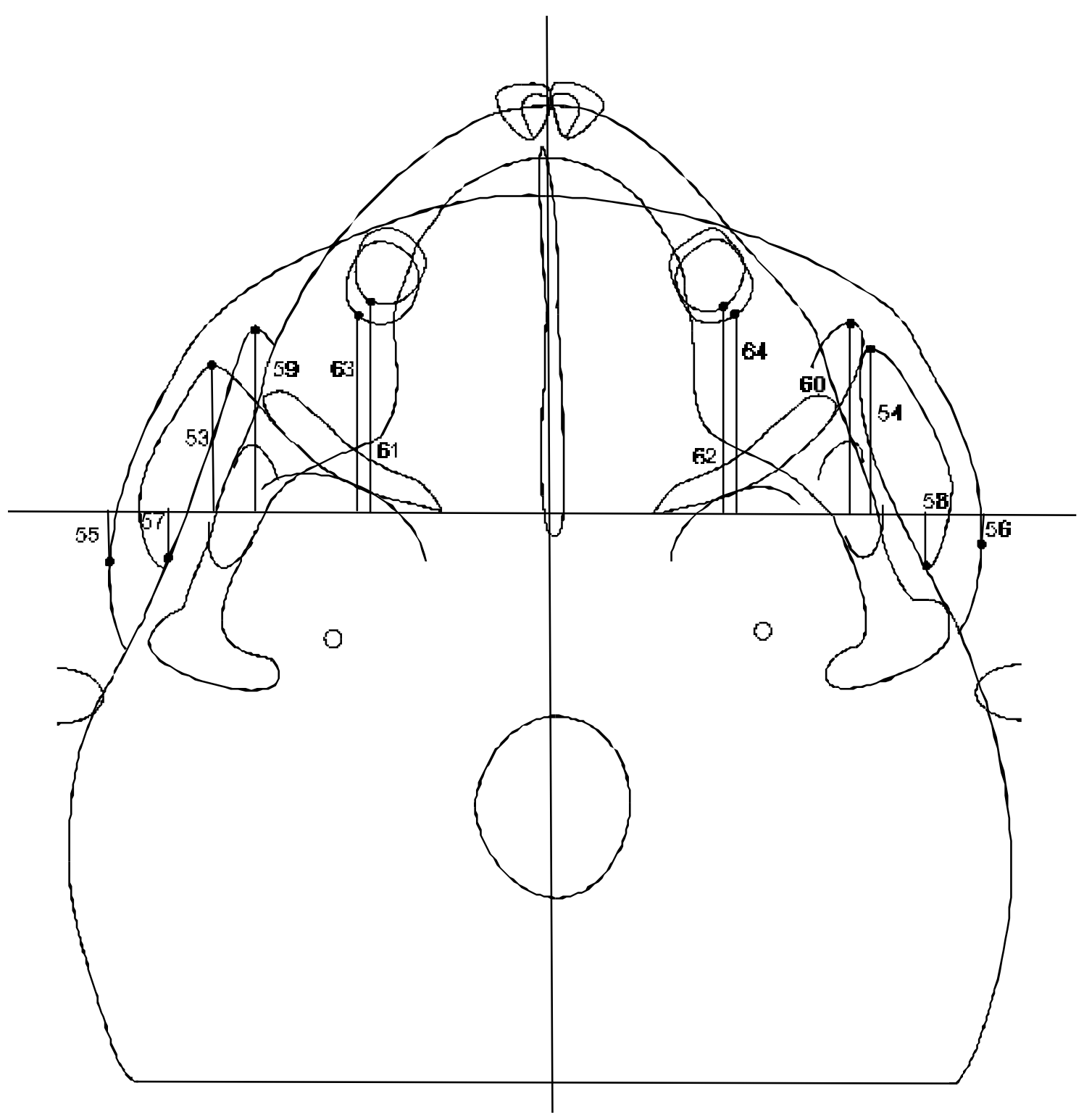

FIGURA 13 - Grandezas cefalométricas da radiografia submentoniana Sistema de Coordenadas do Complexo Zigomaticomaxilar Ântero-Posterior ${ }^{*}$ 


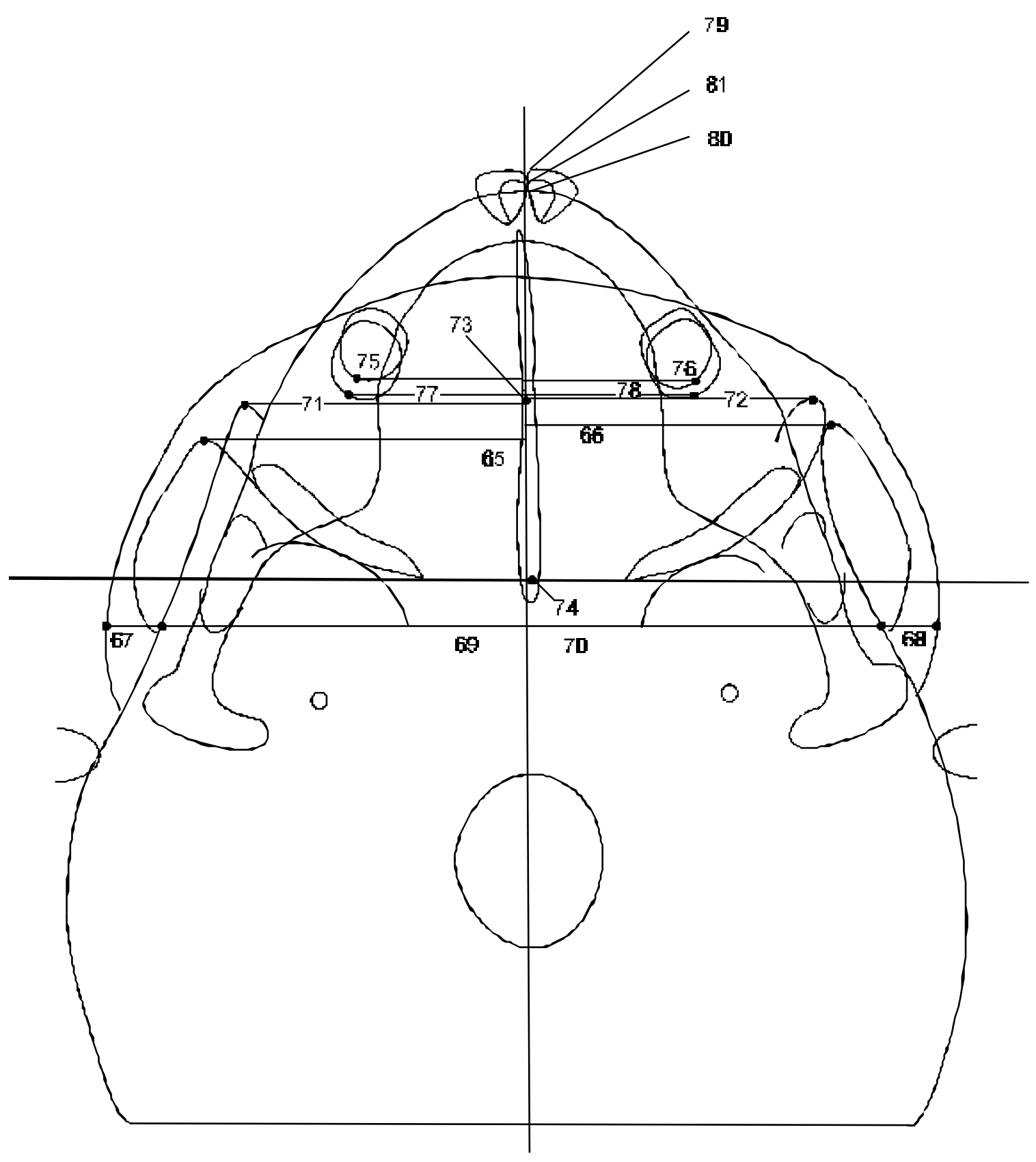

FIGURA 14 - Grandezas cefalométricas da radiografia submentoniana Sistema de Coordenadas do Complexo Zigomaticomaxilar Transverso*

\footnotetext{
${ }^{*}$ FONTE: Figura reproduzida da pesquisa de $\mathrm{JANSON}^{56}$.
} 


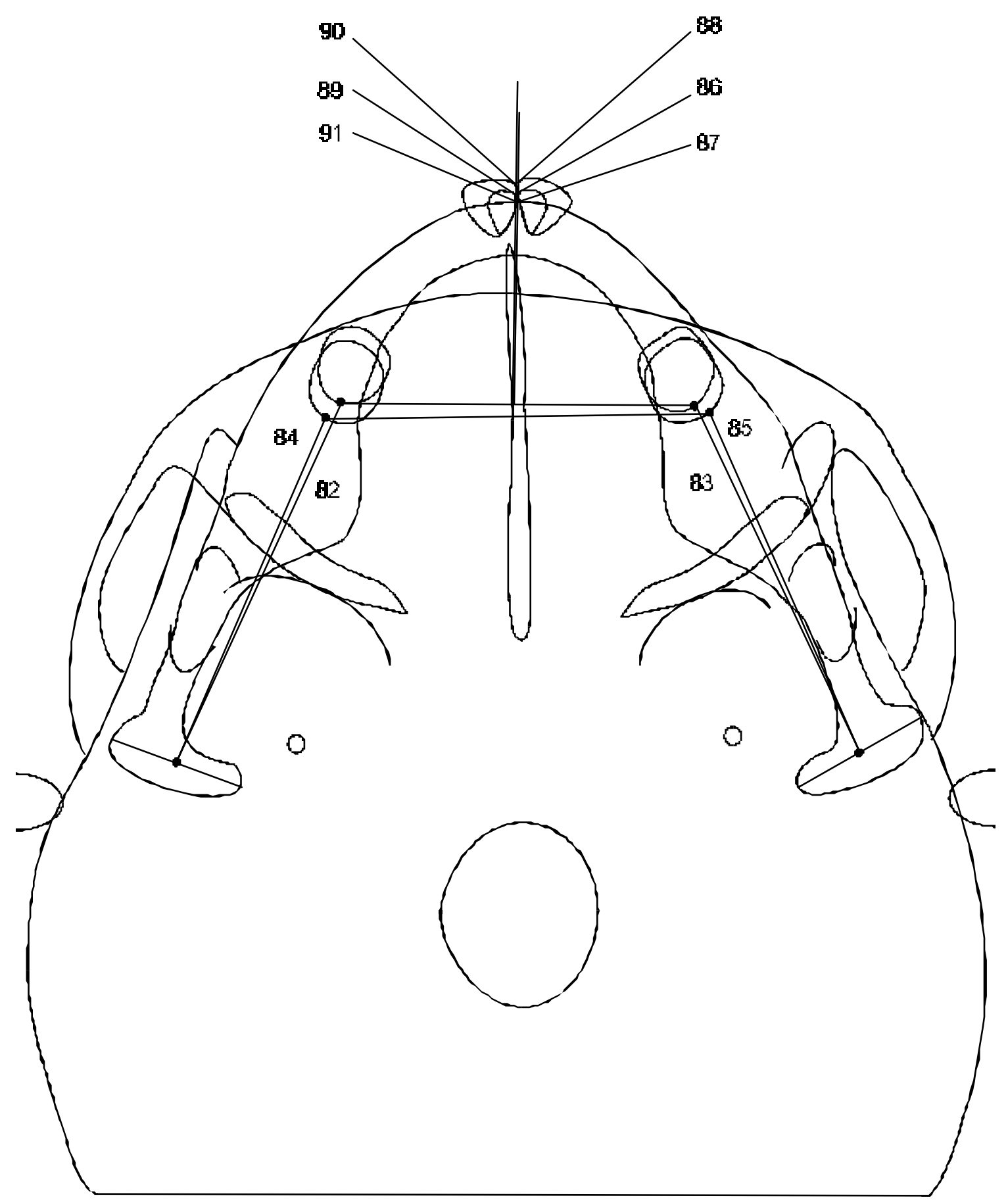

FIGURA 15 - Grandezas cefalométricas da radiografia submentoniana Sistema de Coordenadas Dentárias-Ântero-posterior e Transverso*

\footnotetext{
${ }^{*}$ FONTE: Figura reproduzida da pesquisa de $\mathrm{JANSON}^{56}$.
} 


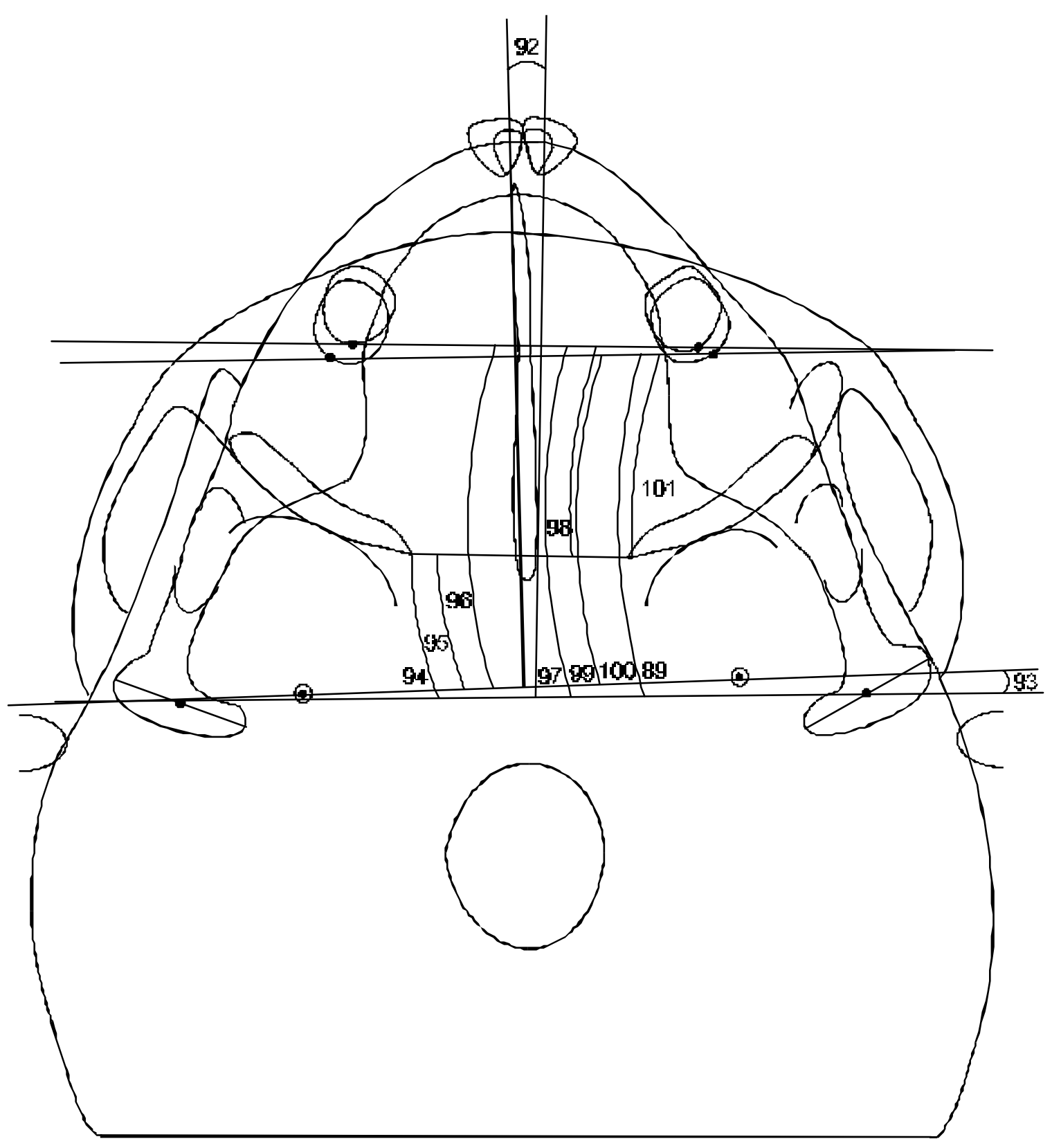

FIGURA 16 - Grandezas cefalométricas da radiografia submentoniana Medidas Angulares entre as abscissas dos Sistemas de Coordenadas $^{*}$

\footnotetext{
${ }^{*}$ FONTE: Figura reproduzida da pesquisa de $\mathrm{JANSON}^{56}$.
} 


\subsection{VARIÁVEIS ADICIONAIS (FIGURA 17)}

102- Distância do ponto condilar médio direito à linha média mandibular (PCMD-LMM).

103- Distância do ponto condilar médio esquerdo à linha média mandibular (PCME-LMM).

104- Ponto condilar médio direito ao contorno médio da mandíbula direita (PCMD-CMMD).

105- Ponto condilar médio esquerdo ao contorno médio da mandíbula esquerda (PCME-CMME).

106- Posição lateral do primeiro molar inferior direito (POSMD).

107- Posição lateral do primeiro molar inferior esquerdo (POSME).

108- Posição lateral do primeiro molar superior direito (POSMSD).

109- Posição lateral do primeiro molar superior esquerdo (POSMSE).

\subsection{DIFERENÇAS ENTRE AS MEDIDAS BILATERAIS}

\subsection{COORDENADAS MANDIBULARES}

\subsection{1 ÂNTERO-POSTERIOR}

110- Diferença de GO ao ETC (1-2).

111 - Diferença de PPC ao ETC (3-4).

112- Diferença de PDMI ao ETC (5-6).

113- Diferença PDMS ao ETC (7-8). 


\subsection{2 TRANSVERSO}

114- Diferença de GO ao EIC (9-10).

115- Diferença de PPC ao EIC (11-12).

116- Diferença de PDMI ao EIC (13-14).

117- Diferença PDMS ao EIC (15-16).

\subsection{COORDENADAS DO ASSOALHO CRANIANO}

\subsection{1 ÂNTERO-POSTERIOR}

118- Diferença de PCM ao ETE (20-21).

119- Diferença de GO ao ETE (22-23).

120- Diferença de PPC ao ETE (24-25).

121 - Diferença de PDMI ao ETE (26-27).

122- Diferença PDMS ao ETE (28-29).

123- Diferença de ACP ao ETE (30-31).

124- Diferença deFCM-ETE (32-33).

\subsection{2 TRANSVERSO}

125- Diferença de PCM ao EIE (34-35).

126- Diferença de GO ao EIE (36-37).

127- Diferença de PPC ao EIE (38-39).

128- Diferença de PDMI ao EIE (40-41).

129- Diferença PDMS ao EIE (42-43).

130- Diferença de ACP ao EIE (47-48).

131- Diferença de FCM ao EIE (49-50). 


\subsection{COMPLEXO ZIGOMÁTICOMAXILAR}

\subsection{1 ÂNTERO-POSTERIOR}

132- Diferença de BC ao ETPTM (53-54).

133- Diferença de ZP ao ETPTM (55-56).

134- Diferença de ACA ao ETPTM (57-58).

135- Diferença de A ao ETPTM (59-60).

136- Diferença de PDMI ao ETPTM (61-62).

137- Diferença de PDMS ao ETPTM (63-64).

\subsection{2 TRANSVERSO}

138- Diferença de BC ao EIPTM (65-66).

139- Diferença de ZP ao EIPTM (67-68).

140- Diferença de ACA ao EIPTM (69-70).

141- Diferença de A ao EIPTM (71-72).

142- Diferença de PDMI ao EIPTM (75-76).

143- Diferença de PDMS ao EIPTM (77-78).

\subsection{COORDENADAS DENTÁRIAS}

\subsection{1 ÂNTERO-POSTERIOR}

144- Diferença de PDMI ao PCM (82-83).

145- Diferença de PDMS ao PCM (84-85).

\subsection{VARIÁVEIS ADICIONAIS}

146- Diferença entre PCM-LMM (102-103).

147- Diferença entre PCM-CMM (104-105).

148- Diferença de POSM (106-107).

149- Diferença de POSMS (108-109). 


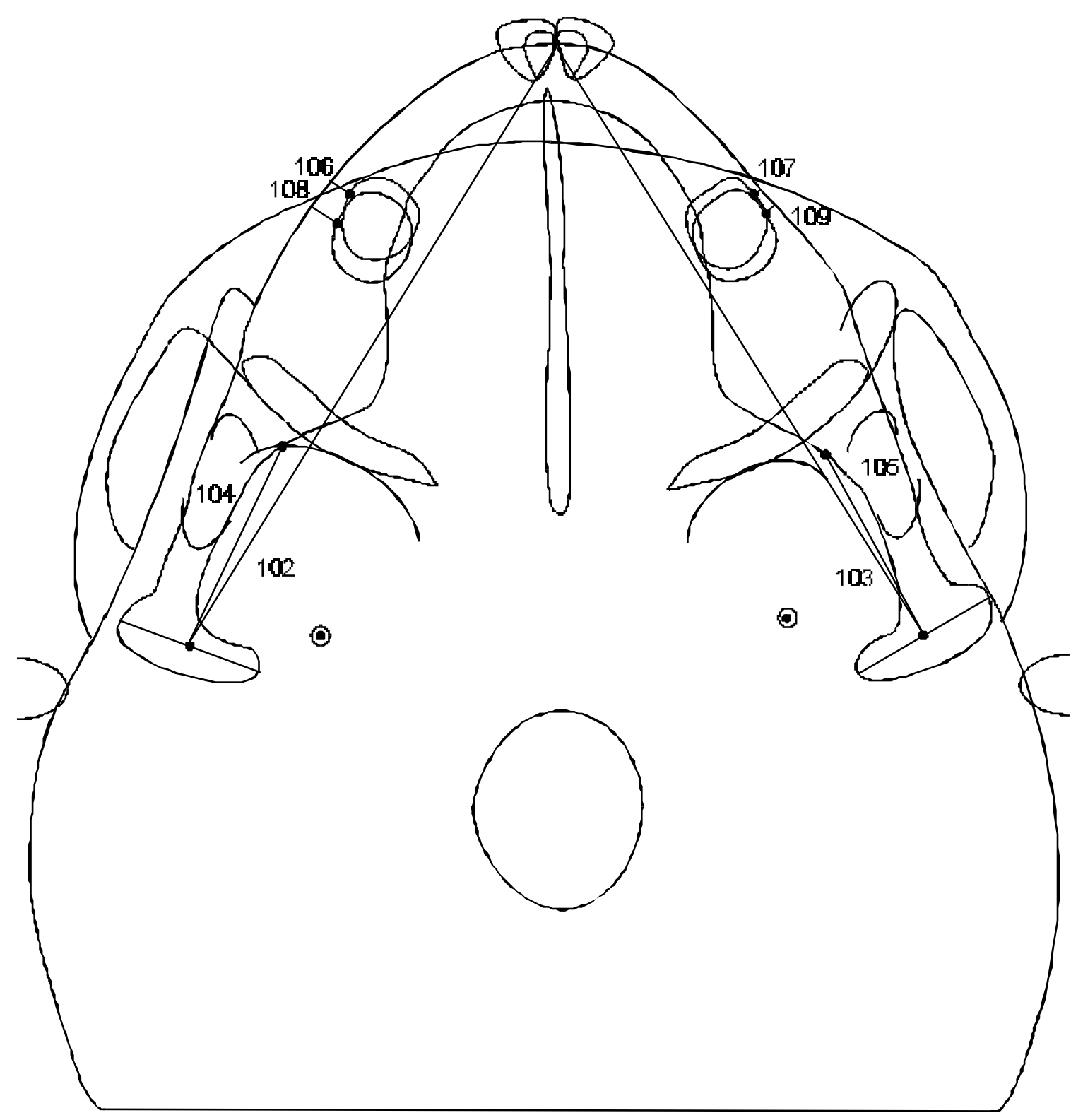

FIGURA 17 - Grandezas cefalométricas da radiografia submentoniana Variáveis Adicionais*

\footnotetext{
${ }^{*}$ FONTE: Figura reproduzida da pesquisa de $\mathrm{JANSON}^{56}$.
} 


\subsubsection{RADIOGRAFIAS PÓSTERO-ANTERIORES}

As radiografias póstero-anteriores foram obtidas utilizando-se a seguinte técnica: cada indivíduo foi posicionado no cefalostato, com a testa e o nariz tocando levemente 0 chassis ${ }^{47}$. O aparelho utilizado para essas radiografias foi o ROENTAX $10090^{\mathrm{d}}$, com filme Kodak X-Omat $\mathrm{K}$ (não interfoliado) e tempo de exposição de 1s, a 90kVp e 25ma. A distância do ponto focal até às olivas metálicas foi padronizada em $152 \mathrm{~cm}$ e a distância das olivas metálicas até o filme foi fixada em $16 \mathrm{~cm}$, o que forneceu um fator de magnificação de 8,91\%. Durante a tomada das radiografias, os indivíduos mantiveram os dentes em máxima intercuspidação habitual.

A delimitação das estruturas anatômicas, a demarcação dos pontos e linhas e a obtenção das grandezas cefalométricas foram realizadas nas radiografias, de acordo com GRUMMONS; VAN DE COPPELLO ${ }^{45}$.

\subsubsection{ESTRUTURAS ANATÔMICAS (FIGURA 18)}

Para as estruturas bilaterais os números referem-se às estruturas enumeradas e às suas homólogas, do lado oposto.

1 - Órbitas

2 - Contornos da cavidade nasal

3 - Crista Galli

4 - Arcos Zigomáticos

5 - Contorno mandibular de um côndilo a outro

6 - Contornos maxilares direito e esquerdo

7 - Aspectos laterais do osso frontal

8 - Aspectos laterais dos ossos zigomáticos

9 - Incisivos centrais superiores

10 - Incisivos centrais inferiores

11 - Primeiros molares superiores

12 - Primeiros molares inferiores

\footnotetext{
${ }^{d}$ EMIC (Eletro Medicina Indústria e Comércio LTDA - R. Paulo Franco, 195, São Paulo - SP Brasil - Fone: (11) 8321131).
} 


\subsubsection{PONTOS DE REFERÊNCIA (FIGURA 19)}

1 - Ponto mais superior no contorno da margem da órbita direita, localizado à meia distância, entre as margens média e lateral.

2 - Ponto localizado na borda lateral da órbita direita, na porção interna da sutura frontozigomática.

3 - Ponto mais inferior do contorno da órbita direita, localizado aproximadamente à meia distância, entre as margens média e lateral.

4 - Ponto mais medial do contorno da órbita direita, localizado aproximadamente à meia distância, entre as margens superior e inferior.

5 - Ponto mais superior do contorno da órbita esquerda, localizado aproximadamente à meia distância, entre as margens média e lateral.

6 - Ponto mais medial do contorno da órbita esquerda, localizado aproximadamente à meia distância, entre as margens superior e inferior.

7 - Ponto mais inferior do contorno da órbita esquerda, localizado aproximadamente à meia distância, entre as margens medial e lateral.

8 - Ponto localizado na borda lateral da órbita esquerda, na porção interna da sutura frontozigomática.

9 - Ponto mais superior do contorno do orifício nasal.

10 - Ponto mais lateral do contorno do orifício nasal, na região da abertura piriforme direita.

11 - Ponto localizado na intersecção do septo nasal com o assoalho do nariz.

12 - Ponto mais lateral do contorno do orifício nasal, na região da abertura piriforme esquerda.

13 - Ponto de referência látero-superior direito: ponto localizado na porção lateral da sutura frontozigomática direita, ou na intersecção da asa maior direita do esfenóide e da margem orbitária.

14 - Ponto na margem lateral do arco zigomático direito, centrado verticalmente. 
15 - Ponto localizado na profundidade da concavidade do contorno lateral do maxilar direito, na junção da maxila e do osso zigomático.

16 - Ponto de referência látero-superior esquerdo: ponto localizado na porção lateral da sutura frontozigomática esquerda, ou na intersecção da asa maior do esfenóide e da margem orbitária.

17 - Ponto na margem lateral do arco zigomático esquerdo, centrado verticalmente.

18 - Ponto localizado na profundidade da concavidade do contorno lateral do maxilar esquerdo, na junção da maxila e do osso zigomático.

19 - Ponto localizado numa perpendicular à superfície oclusal do primeiro molar superior direito, através da cúspide vestibular, na altura da raiz vestibular (verticalmente).

20 - Ponta de cúspide vestibular do primeiro molar superior direito.

21 - Ápice radicular do incisivo central superior direito.

22 - Ponto localizado no meio da borda incisal do incisivo central superior direito.

23 - Ponto localizado apicalmente entre as raízes dos incisivos centrais superiores, distante aproximadamente $2 / 3$ do comprimento radicular ${ }^{21}$.

24 - Ápice radicular do incisivo central superior esquerdo.

25 - Ponto localizado no meio da borda incisal do incisivo central superior esquerdo.

26 - Ponto localizado numa perpendicular à superfície oclusal do primeiro molar superior esquerdo, através da cúspide vestibular, na altura da raiz vestibular.

27 - Ponta de cúspide vestibular do primeiro molar superior esquerdo.

28 - Ponta de cúspide vestibular do primeiro molar inferior direito.

29 - Ponto localizado no ápice radicular, através de uma perpendicular traçada à superfície oclusal do primeiro molar inferior direito, a partir da cúspide vestibular. 
30 - Ponto centrado na borda incisal do incisivo central inferior direito.

31 - Ápice radicular do incisivo central inferior direito.

32 - Ponto localizado apicalmente entre as raízes dos incisivos centrais inferiores, distante aproximadamente $2 / 3$ do comprimento radicular ${ }^{21}$.

33 - Ponto centrado na borda incisal do incisivo central inferior esquerdo.

34 - Ápice radicular do incisivo central inferior esquerdo.

35 - Ponta de cúspide vestibular do primeiro molar inferior esquerdo.

36 - Ponto localizado no ápice radicular do primeiro molar inferior esquerdo, através de uma perpendicular traçada na sua superfície oclusal, a partir da cúspide vestibular.

37 - Ponto centrado na superfície superior da cabeça do côndilo direito.

38 - Ponto localizado na borda lateral da cabeça do côndilo direito.

39 - Ponto localizado na borda lateral do ramo mandibular direito, localizado aproximadamente à meia distância, entre a cabeça do côndilo e o ângulo goníaco.

40 - Ponto localizado na junção da borda lateral do ramo mandibular direito com o início da convexidade do ângulo goníaco direito.

41 - Ponto localizado no ângulo goníaco direito da mandíbula.

42 - Ponto localizado na chanfradura antegoniana direita.

43 - Ponto localizado na superfície inferior do corpo mandibular direito, entre o ângulo goníaco e a sínfise.

44 - Ponto localizado na superfície inferior do corpo mandibular direito, representando o limite lateral direito da concavidade da sínfise (se existir).

45 - Ponto mentoniano que consiste no ponto mais inferior na borda da mandíbula, na sínfise.

46 - Ponto localizado na superfície inferior do corpo mandibular esquerdo, representando o limite lateral esquerdo da concavidade da sínfise (se existir). 
47 - Ponto na superfície inferior do corpo mandibular esquerdo, à meia distância entre o ângulo goníaco e a sínfise.

48 - Ponto localizado na chanfradura antegoniana esquerda.

49 - Ponto localizado no ângulo goníaco esquerdo da mandíbula.

50 - Ponto localizado na junção da borda lateral do ramo mandibular esquerdo, com o início da convexidade do ângulo goníaco esquerdo.

51 - Ponto na borda lateral do ramo mandibular esquerdo, aproximadamente à meia distância entre a cabeça do côndilo e o ângulo goníaco.

52 - Ponto localizado na borda lateral da cabeça do côndilo esquerdo.

53 - Ponto centrado na superfície superior da cabeça do côndilo esquerdo.

54 - Ponto mais superior da crista Galli, idealmente no meio do osso.

55 - Espinha nasal anterior.

56 - Ponto médio de intercuspidação das pontas de cúspides dos primeiros molares superior e inferior, do lado direito (construído).

57 - Ponto médio de intercuspidação das pontas de cúspides dos primeiros molares superior e inferior, do lado esquerdo (construído).

58 - Ponto médio entre os incisivos superiores (construído).

59 - Ponto médio entre os incisivos inferiores (construído).

\subsubsection{LINHAS E PLANOS (FIGURA 20)}

A - $\quad$ Plano Z (linha) - formado pela conexão dos pontos 2 e 8.

$B$ - $\quad$ Linha- $X^{46}$ - linha perpendicular ao plano $Z$, passando pela crista Galli.

C - Plano oclusal - plano formado entre os pontos médios de intercuspidação das pontas de cúspides dos primeiros molares superior e inferior, de cada lado, respectivamente (pontos 56 e 57, construídos). 
D - Plano antegoniano - plano formado entre os pontos $42 \mathrm{e}$ 48 (chanfradura antegoniana).

E - $\quad$ Linha do ramo mandibular direito (formada pelos pontos 37 e 42).

F - Linha do ramo mandibular esquerdo (formada pelos pontos 53 e 48).

G - Linha do corpo mandibular direito (formada pelos pontos 42 e 45$)$.

H - Linha do corpo mandibular esquerdo (formada pelos pontos 45 e 48).

\subsubsection{GRANDEZAS CEFALOMÉTRICAS (FIGURA 21 e 22)}

Para a obtenção das medidas lineares bilaterais ou das estruturas não pareadas, a medição foi realizada da estrutura em questão até a linha de referência vertical média (Linha-X), paralelamente ao plano $Z$.

1 - Ângulo do plano Z (ÂPLANOZ) - Ângulo entre o plano Z (8 e 2) e a linha Cg (Crista Galli) - ENA (54 e 55) (FIGURA 21).

2 - Ângulo do plano oclusal (ÂPLOCUSAL) - Ângulo entre o plano oclusal (pontos ns 56 e 57, construídos) e a linha Cg (Crista Galli) - ENA (54 e 55) (FIGURA 21).

3 - Ângulo do plano antegoniano (ÂPLANTEG) - Ângulo entre o plano antegoniano (pontos n ${ }^{\circ} \mathrm{s} 42$ e 48) e a linha Cg (Crista Galli) - ENA (54 e 55) (FIGURA 21).

4 - Desvio da espinha nasal anterior (DESVENA) - Distância (ponto linha) entre a espinha nasal anterior (55) e a Linha-X (FIGURA 22).

5 - Desvio mandibular (DESMAND) - Distância (ponto-linha) entre o mentoniano (45) e a Linha-X (FIGURA 22).

6 - Desvio da linha média superior (A1) - Distância (pontolinha) entre a linha média dos incisivos superiores (58) e a Linha-X (FIGURA 22). 
7 - Desvio da linha média inferior (B1) - Distância (pontolinha) entre a linha média dos incisivos inferiores (59) e a Linha-X (FIGURA 22).

8 - Ângulo antegoniano direito (ÂANTD) - Ângulo entre 0 ramo mandibular (37 e 42) e o corpo mandibular direito (42 e 45) (FIGURA 21).

9 - Ângulo antegoniano esquerdo (ÂANTE) - Ângulo entre o ramo mandibular (48 e 53) e o corpo mandibular esquerdo (45 e 48) (FIGURA 21).

10 - Distância Z direita (DISTZD) - Distância horizontal entre a sutura frontozigomática (ponto Z) direita(2) e a Linha-X (FIGURA 22).

11 - Distância Z esquerda (DISTZE) - Distância horizontal entre a sutura frontozigomática (ponto Z) esquerda(8) e a Linha-X (FIGURA 22).

12 - Distância CO direita (DISTCOD) - Distância horizontal entre o condílio direito (37) e a Linha-X (FIGURA 22).

13 - Distância CO esquerda (DISTCOE) - Distância horizontal entre o condílio esquerdo (53) e a Linha-X (FIGURA 22).

14 - Distância ZA direita (DISTZAD) - Distância horizontal entre o zygoma direito (14) e a Linha-X (FIGURA 22).

15 - Distância ZA esquerda (DISTZAE) - Distância horizontal entre o zygoma esquerdo (17) e a Linha-X (FIGURA 22).

16 - Distância NC direita (DISTNCD) - Distância horizontal entre a parede lateral da abertura piriforme direita (10) e a Linha-X (FIGURA 22).

17 - Distância NC esquerda (DISTNCE) - Distância horizontal entre a parede lateral da abertura piriforme esquerda (12) e a Linha-X (FIGURA 22).

18 - Distância J direita (DISTJD) - Distância horizontal entre o processo jugal direito da maxila (15) e a Linha-X (FIGURA 22).

19 - Distância J esquerda (DISTJE) - Distância horizontal entre o processo jugal esquerdo da maxila (18) e a Linha-X (FIGURA 22).

20 - Distância AG direita (DISTAGD) - Distância horizontal entre a chanfradura antegoniana direita (42) e a Linha-X (FIGURA 22).

21 - Distância AG esquerda (DISTAGE) - Distância horizontal entre a chanfradura antegoniana esquerda (48) e a Linha-X (FIGURA 22). 
22 - Altura do primeiro molar superior direito (ALTㅁD) Distância vertical entre o processo jugal direito (15) e a ponta de cúspide vestibular do primeiro molar superior direito (20) (FIGURA 22).

23 - Altura do primeiro molar superior esquerdo (ALTㅌE) Distância vertical entre o processo jugal esquerdo (18) e a ponta de cúspide vestibular do primeiro molar superior esquerdo (20) (FIGURA 22).

24 - Distância CO-AG direita (CO-AGD) - Tamanho do ramo mandibular direito, do condílio (37) até a chanfradura antegoniana (42) (FIGURA 22).

25 - Distância CO-AG esquerda (CO-AGE) - Tamanho do ramo mandibular esquerdo, do condílio (53) até a chanfradura antegoniana (48) (FIGURA 22).

26 - Distância CO-ME direita (CO-MED) - Tamanho do lado direito da mandíbula, do condílio (37) até o mentoniano (45) (FIGURA 22).

27 - Distância CO-ME esquerda (CO-MEE) - Tamanho do lado esquerdo da mandíbula, do condílio (53) até o mentoniano (45) (FIGURA 22).

28 - Distância ME-AG direita (ME-AGD) - Tamanho do corpo mandibular direito, da chanfradura antegoniana (42) até o mentoniano (45) (FIGURA 22).

29 - Distância ME-AG esquerda (ME-AGE) - Tamanho do corpo mandibular esquerdo, da chanfradura antegoniana (48) até 0 mentoniano (45) (FIGURA 22).

\subsection{DIFERENÇAS ENTRE AS MEDIDAS BILATERAIS}

As diferenças entre as medidas bilaterais consistiram na assimetria dos casos avaliados.

30 - Diferença ângulo antegoniano - ÂANT - (8-9).

31 - Diferença distância Z-DISTZ - (10-11).

32 - Diferença distância CO-DISTCO - (12-13).

33 - Diferença distância ZA-DISTZA - (14-15).

34 - Diferença distância NC-DISTNC - (16-17). 
35 - Diferença distância J-DISTJ - (18-19).

36 - Diferença distância AG-DISTAG - (20-21).

37 - Diferença altura do primeiro molar superior A6-ALT6 - (22-

23).

38 - Diferença distância CO-AG - CO-AG - (24-25).

39 - Diferença distância CO-ME - CO-ME - (26-27).

40 - Diferença distância ME-AG - ME-AG - (28-29). 


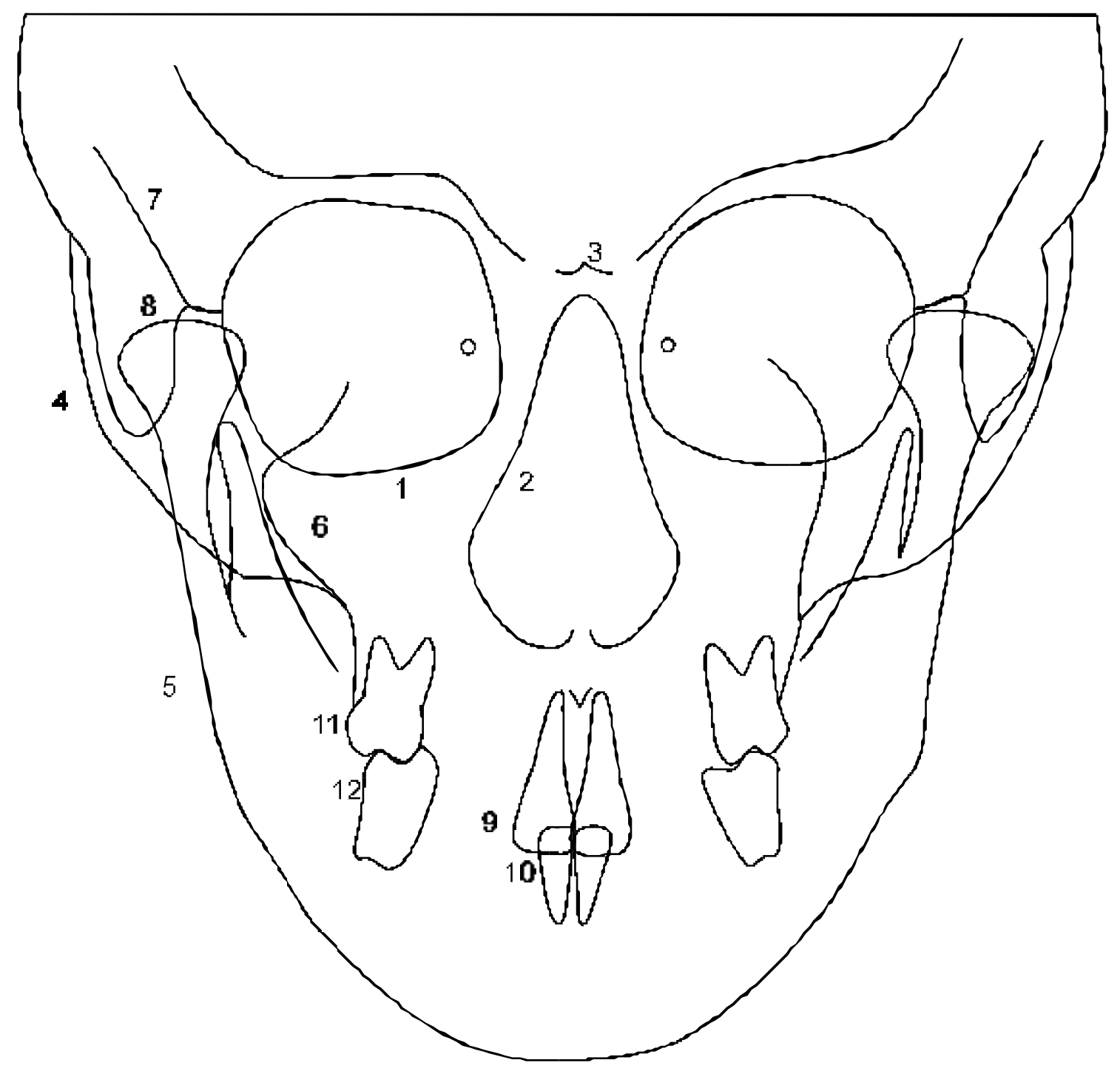

FIGURA 18 - Estruturas anatômicas da radiografia póstero-anterior ${ }^{*}$

\footnotetext{
${ }^{*}$ FONTE: Figura reproduzida da pesquisa de $\mathrm{JANSON}^{56}$.
} 


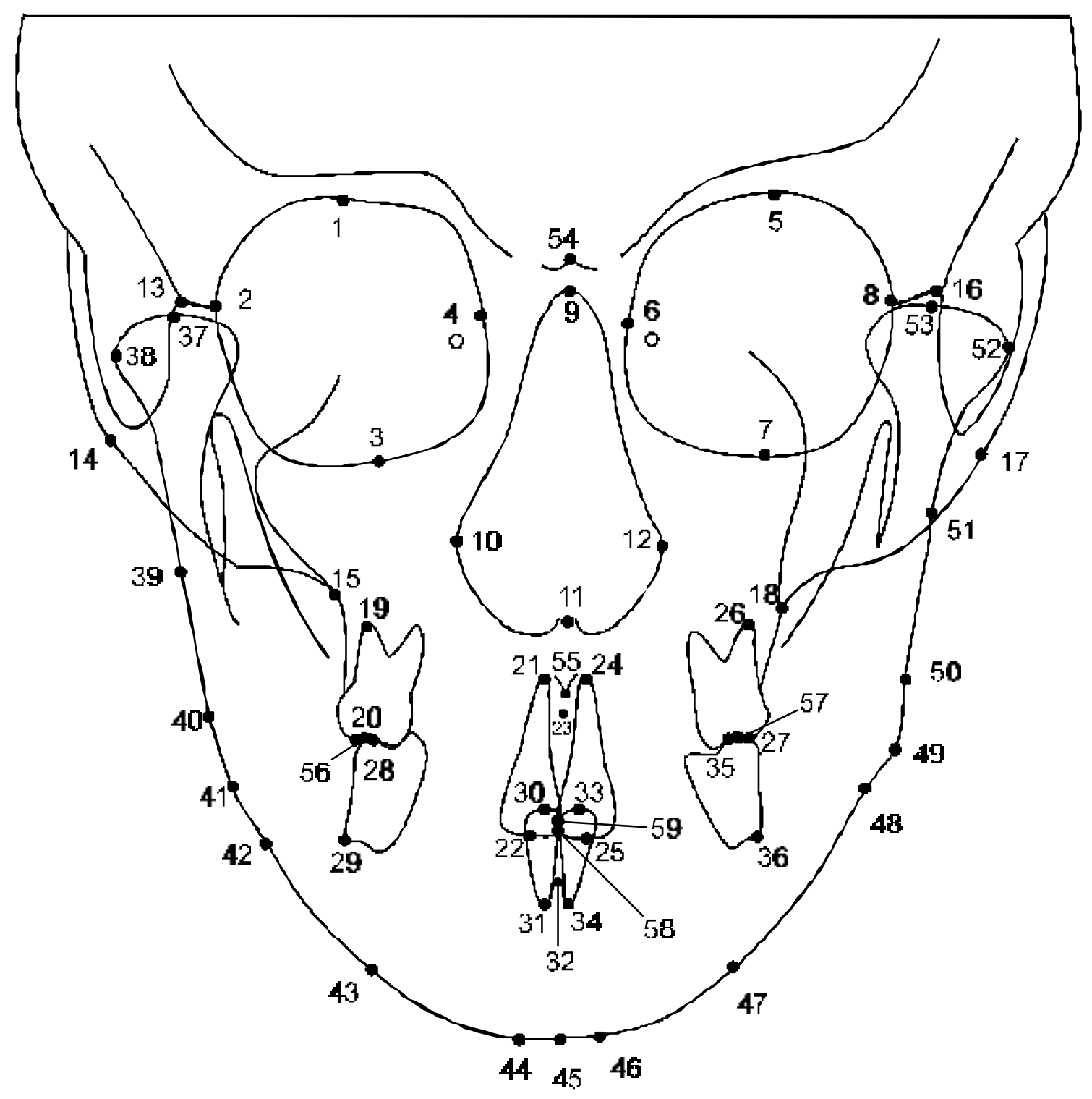

FIGURA 19 - Pontos da radiografia póstero-anterior ${ }^{*}$ 


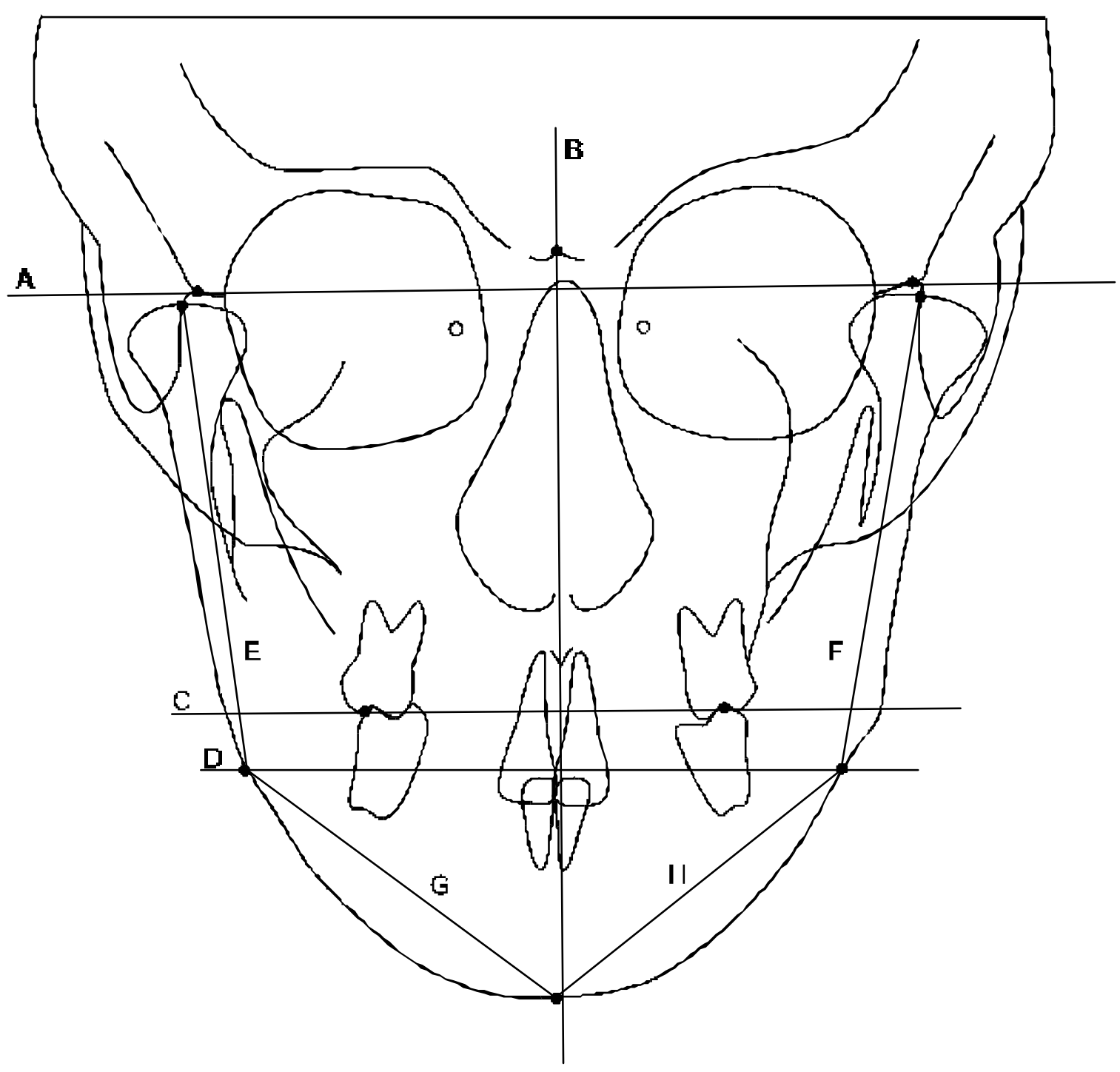

FIGURA 20 - Linhas e planos da radiografia póstero-anterior ${ }^{*}$

\footnotetext{
${ }^{*}$ FONTE: Figura reproduzida da pesquisa de $\mathrm{JANSON}^{56}$.
} 


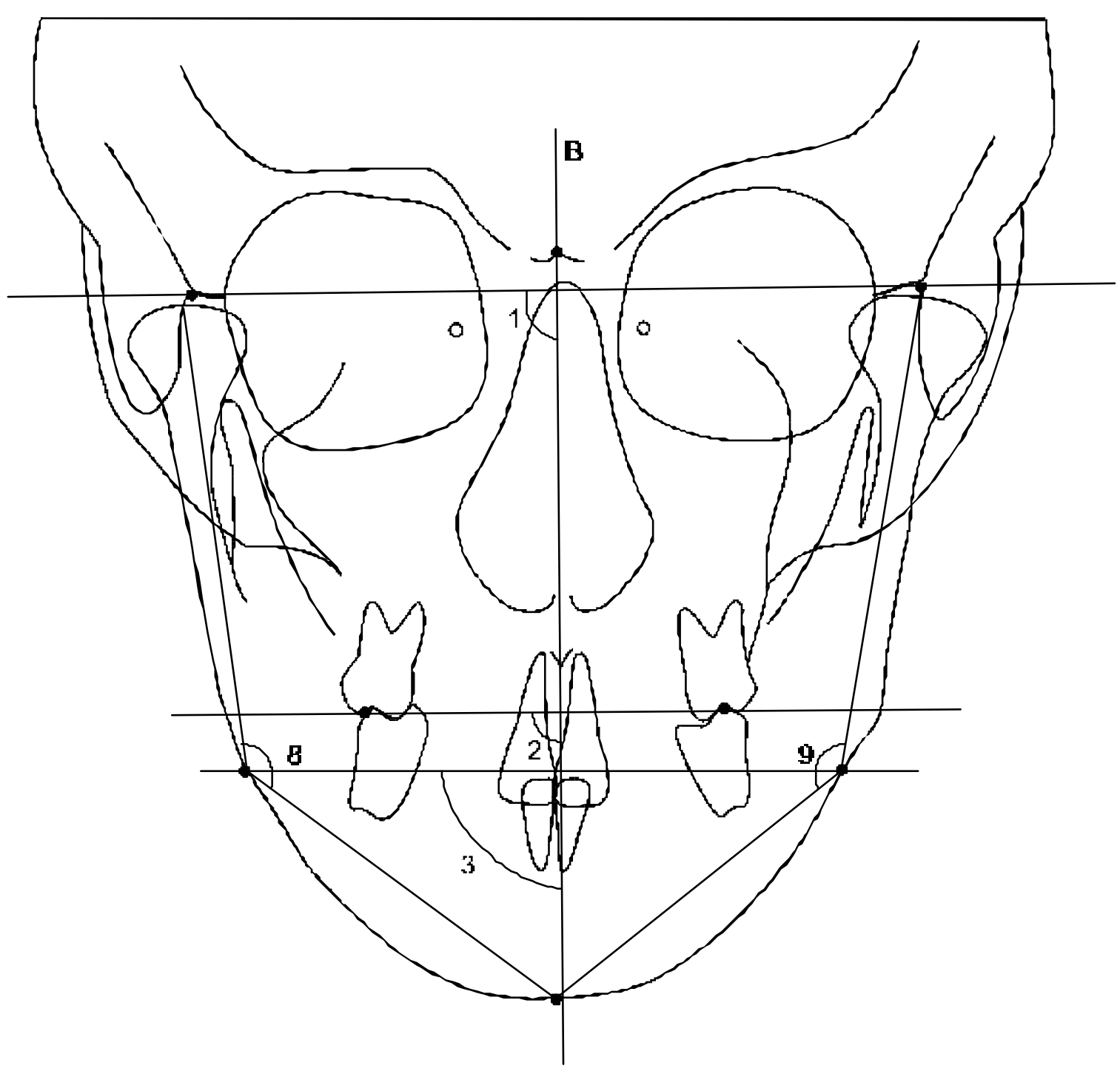

FIGURA 21 - Grandezas angulares da radiografia póstero-anterior

\footnotetext{
${ }^{*}$ FONTE: Figura reproduzida da pesquisa de $\mathrm{JANSON}^{56}$.
} 


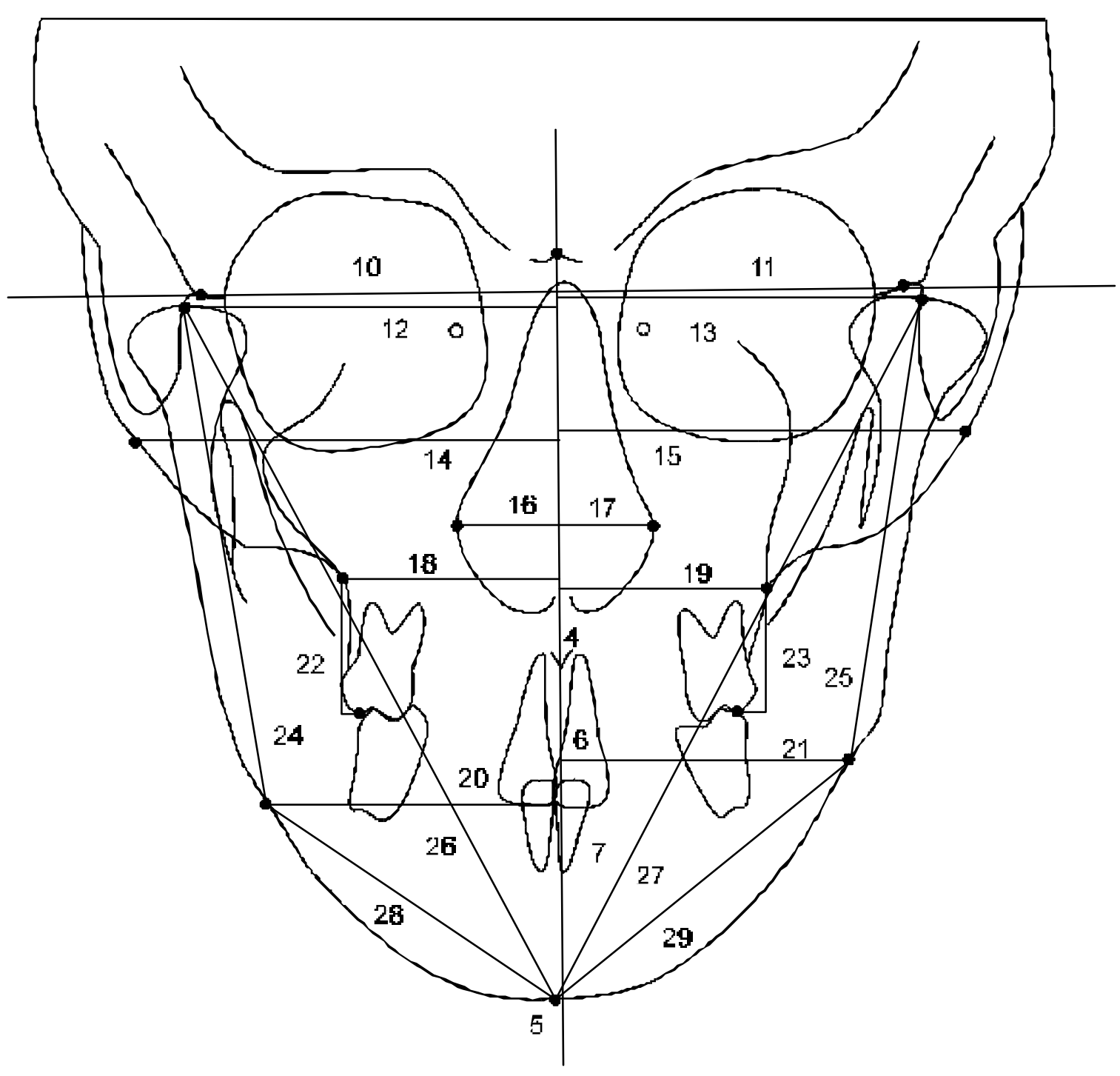

FIGURA 22 - Grandezas lineares da radiografia póstero-anterior ${ }^{*}$ 
Todas as radiografias foram traçadas e os pontos, demarcados manualmente, em papel de acetato transparente "ultraphan", de tamanho 20,3cm x 25,4 cm e 0,07mm de espessura, sobre um negatoscópio em uma sala escurecida. Para melhor delimitação das estruturas anatômicas, adaptout se uma máscara de cartolina preta ao redor da radiografia, para eliminar ao máximo a luminosidade lateral proveniente do negatoscópio. Os traçados cefalométricos e os pontos foram realizados com uma lapiseira provida com grafite $2 \mathrm{~B}$, de $0,5 \mathrm{~mm}$ de diâmetro. As fotografias foram impressas em papel "Glossy Paper", de tamanho A4, de 150 g/m2, em uma impressora HP Deskjet 840 C. Nas fotografias com os lábios em postura relaxada, os pontos foram demarcados com uma caneta Pilot para retroprojetor de $1.0 \mathrm{~mm}$ de diâmetro. Todos os traçados e pontos foram posteriormente conferidos e corrigidos pelo orientador do trabalho, individualmente. Os pontos das fotografias e das radiografias foram digitalizados por meio de uma mesa digitalizadora Hipad DT - 119, conectada a um microcomputador Pentium II - 233 MMX, para a obtenção das grandezas cefalométricas. Para a realização das mensurações dos pontos digitalizados, utilizourse o programa Dentofacial Planner $7.0^{b}$.

\subsubsection{AVALIAÇÃO DA CORRELAÇÃO DA ASSIMETRIA CLÍNICA E RADIOGRÁFICA NO GRUPO TOTAL E NOS SUBGRUPOS}

Como já foi demonstrado em pesquisas anteriores ${ }^{1,55,56,107}$, a má oclusão de Classe II, subdivisão não apresenta uma assimetria esquelética significante quando comparada com indivíduos que apresentam oclusão normal e má oclusão de Classe I. Contudo, alguns casos de Classe II, subdivisão apresentam como causa principal o posicionamento mais distal do primeiro molar inferior, outros como causa principal o posicionamento mais mesial do primeiro molar superior e outros com uma combinação destes. Conseqüentemente, uma assimetria esquelética discreta em um destes subgrupos pode ser atenuada pelos outros subgrupos, anulando a diferença

\footnotetext{
${ }^{a}$ Houston Instruments, Houston, Texas.

${ }^{b}$ Dentofacial Planner Software Inc., 1 First Canadian Place, Suite 870, Toronto, Ontario, Canada M5X1C9.
} 
quando comparado com o grupo normal. Por esta razão, além de analisar a correlação da assimetria dínica (fotografia) com a assimetria radiográfica de todo o grupo com Classe II, subdivisão, seria interessante realizar uma comparação independente dos subgrupos mencionados para investigarmos se a contribuição da assimetria esquelética seria maior ${ }^{56}$. Baseando-se nesta suposição, o grupo experimental foi subdividido em dois grupos de acordo com o tipo de Classe II, subdivisão. O Tipo 1 representa os casos onde a linha média dentária superior está coincidente com a linha média da face e a inferior desviada, o que indicaria uma maior participação do molar inferior na Classe II, subdivisão. Enquanto que o Tipo 2 representa os casos onde a linha média dentária inferior está coincidente com a linha média da face e a superior desviada, o que indicaria uma maior participação do molar superior na Classe II, subdivisão. Realizou-se uma análise frontal do paciente, por duas examinadoras calibradas, mestrandas do Departamento de Ortodontia da Faculdade de Odontologia de Bauru, visualizando as linhas médias dentárias superiores e inferiores. A avaliação do desvio das linhas médias dentárias superior e inferior foi obtida através do método descrito por JERROLD; LOWENSTEIN $^{58}$, que consiste em traçar-se uma linha imaginária, perpendicular ao solo, passando pelo centro da glabela. Essa avaliação frontal é realizada com o paciente sorrindo, em oclusão habitual. As fotografias sorrindo, também, foram scaneadas e impressas, como descrito anteriormente. Os grupos foram denominados da seguinte maneira: $O$ grupo 1 representa a amostra total, ou seja, os 42 indivíduos com má oclusão de Classe II, subdivisão. O grupo 2 representa os indivíduos com Classe II, subdivisão do tipo 1, com 25 indivíduos (59,52\%), sendo 13 do gênero masculino e 12 do feminino, com idade média de 14,81 anos. O grupo 3 representa os indivíduos com Classe II, subdivisão do tipo 2 com 08 indivíduos (19,05\%), sendo 04 do gênero masculino e 04 do feminino, com idade média de 16,36 anos (TABELA $1)$. Os outros nove indivíduos $(21,43 \%)$ rão foram incluídos na divisão dos tipos por apresentarem dúvida quanto a sua classificação. 


\subsubsection{COMPARAÇÃO ENTRE OS GRUPOS}

Verificou-se ainda, que alguns indivíduos com má oclusão de Classe II, subdivisão apresentavam, também, uma assimetria facial aparente. Por esta razão, decidiu-se comparar esses pacientes com assimetria facial aparente e indivíduos com oclusão normal, para verificarmos a participação da assimetria dentoesquelética nestes dois grupos. O grupo de pacientes com Classe II, subdivisão e assimetria facial aparente foi selecionado por meio de uma avaliação realizada por três examinadores calibrados. Os examinadores avaliaram as fotografias frontais de todos os pacientes com Classe II, subdivisão e separaram as fotos em indivíduos com e sem assimetria facial aparente. Foram utilizados três examinadores, pois se houvesse empate quanto à avaliação de um indivíduo, o terceiro examinador desempataria. A idade média para este grupo foi de 15,78 (TABELA 1), sendo 12 indivíduos do gênero masculino e 11 do feminino.

TABELA 1 - Médias, desvios-padrão, máximo e mínimo das idades do grupo experimental subdividido de acordo com o tipo de Classe II, subdivisão

\begin{tabular}{|c|c|c|c|c|}
\hline Grupo & Média & dp & Mínimo & Máximo \\
\hline Grupo 1 & $15,21 \mathrm{a}$ & $3,78 \mathrm{a}$ & $11,90 \mathrm{a}$ & $31,98 \mathrm{a}$ \\
\hline Grupo 2 & $14,81 \mathrm{a}$ & $4,07 \mathrm{a}$ & $12,06 \mathrm{a}$ & $31,98 \mathrm{a}$ \\
\hline Grupo 3 & $16,36 \mathrm{a}$ & $3,66 \mathrm{a}$ & $12,12 \mathrm{a}$ & $22,70 \mathrm{a}$ \\
\hline Assimetria & $15,78 \mathrm{a}$ & $4,68 \mathrm{a}$ & $11,90 \mathrm{a}$ & $31,98 \mathrm{a}$ \\
\hline Controle & 22,42 & $5,60 \mathrm{a}$ & $15,10 \mathrm{a}$ & $41,06 \mathrm{a}$ \\
\hline
\end{tabular}

\subsubsection{ERRO DO MÉTODO}

Para se efetuar 0 erro do método, foram retraçadas, redigitalizadas e medidas novamente as radiografias de 10 indivíduos do grupo com má oclusão de Classe II, subdivisão, selecionados aleatoriamente, após um mês do final de todos os traçados, num total de 20 radiografias. Também, 
foram selecionadas ao acaso 10 fotografias frontais de indivíduos com Classe II, subdivisão, onde estas foram impressas novamente, redigitalizadas e medidas. Foi aplicada a fórmula proposta por DAHLBERG ${ }^{27}\left(\mathrm{Se}^{2}=\right.$ somatória $\left.d^{2} / 2 n\right)$ para estimarmos a ordem de grandeza dos erros casuais. O erro sistemático foi calculado por meio do teste t pareado ${ }^{12,42,51,103}$.

\subsubsection{ANÁLISE ESTATÍSTICA}

O teste de correlação de Pearson foi utilizado entre as medidas das fotografias frontais e as medidas das radiografias submentonianas e póstero-anteriores dos indivíduos com Classe II, subdivisão, para verificarmos a existência de correlação entre a assimetria clínica e a assimetria radiográfica no grupo 1 de Classe II, subdivisão completa e os subgrupos 2 e 3 .

Outro teste estatístico utilizado, foi o teste $t$ independente para comparação entre o grupo com má oclusão de Classe II, subdivisão e assimetria facial aparente e o grupo com oclusão normal. Os resultados foram considerados estatisticamente significantes para $p<0,05$, em ambos os testes estatísticos.

Todas as análises foram realizadas com o programa Statística ${ }^{\mathrm{e}}$.

\footnotetext{
${ }^{\text {e }}$ Statística for Windows - Release 5.0A - Copyright $^{\circledR}$ StatSoft, Inc. 1995.
} 
5 Resultados 


\section{RESULTADOS}

Os resultados serão aqui apresentados nas tabelas que se seguem. Primeiramente, na tabela 2 encontram-se as médias dos valores absolutos para as medidas das fotografias frontais, em porcentagem, dos grupos 1, 2 e 3 . Nas tabelas de 3 a 10 estão dispostos os valores dos erros casuais e sistemáticos. As tabelas de 11 a 15 representam os resultados do teste de correlação de Pearson ( $r$ ) entre as medidas da fotografia frontal e as medidas das radiografias submentonianas e póstero-anteriores para os grupos. Os resultados do teste " $\mathrm{t}$ " independente para comparar as assimetrias dentoesqueléticas entre o grupo experimental com assimetria facial aparente e o grupo controle estão dispostos nas tabelas de 16 a 22. 
TABELA 2 - Valores absolutos das médias das medidas das fotografias frontais dos grupos 1 (42 pacientes com Classe II, subdivisão), 2 (25 pacientes com Classe II, subdivisão, tipo 1) e 3 (8 pacientes com Classe II, subdivisão, tipo 2)

\begin{tabular}{|l|r|r|r|r|r|r|}
\hline \multirow{2}{*}{ Variáveis } & \multicolumn{2}{|c|}{ Grupo 1 } & \multicolumn{2}{c|}{ Grupo 2 } & \multicolumn{2}{c|}{ Grupo 3 } \\
\cline { 2 - 7 } & Média & \multicolumn{1}{c|}{ D.P } & \multicolumn{1}{c|}{ Média } & \multicolumn{1}{c|}{ D.P } & \multicolumn{1}{c|}{ Média } & \multicolumn{1}{c|}{ D.P } \\
\hline ZyDMe/ZYEMe & 100,68 & 1,58 & 100,62 & 1,66 & 100,45 & 0,96 \\
\hline GoDMe/GoEMe & 102,07 & 4,48 & 102,49 & 4,01 & 102,58 & 3,84 \\
\hline ZyDGoD/ZYEGoE & 100,40 & 3,19 & 100,04 & 2,96 & 99,81 & 1,75 \\
\hline Me & 0,74 & 0,53 & 0,65 & 0,47 & 0,87 & 0,38 \\
\hline Sbn & 0,58 & 0,47 & 0,70 & 0,54 & 0,40 & 0,23 \\
\hline
\end{tabular}

TABELA 3 - Análise intra-examinador da precisão da metodologia empregada: apresentação dos erros casuais de DAHLBERG ${ }^{27}$, das médias, dos desvios padrão (D.P.) das diferenças e nível de significância estatística dos erros sistemáticos, entre a primeira e a segunda medição das fotografias

\begin{tabular}{|l|r|r|r|c|}
\hline \multicolumn{1}{|c|}{ Variáveis } & DAHLBERG & $\begin{array}{c}\text { MÉDIA } \\
\text { DIFERENÇA }\end{array}$ & $\begin{array}{c}\text { D.P. } \\
\text { DIFERENÇA }\end{array}$ & p \\
\hline ZyD to Me & 0,27 & $-0,19$ & 0,55 & 0,30522911 \\
\hline ZyE to Me & 0,40 & $-0,43$ & 0,71 & 0,08963051 \\
\hline GoD to Me & 0,48 & 0,17 & 1,01 & 0,60972431 \\
\hline GoE to Me & 0,45 & $-0,64$ & 0,69 & 0,01684961 \\
\hline ZyD to GoD & 0,39 & $-0,30$ & 0,76 & 0,24848297 \\
\hline ZyE to GoE & 0,32 & 0,14 & 0,66 & 0,52247338 \\
\hline ZyDMe/ZyEMe & 0,47 & 0,34 & 0,93 & 0,28197731 \\
\hline GoDMe/GoEMe & 1,85 & 2,08 & 3,23 & 0,07228632 \\
\hline ZyDGoD/ZyEGoE & 1,47 & $-1,03$ & 2,91 & 0,29344189 \\
\hline Me & 0,37 & 0,60 & 0,78 & 0,81373575 \\
\hline Sbn & 0,26 & $-0,05$ & 0,55 & 0,78189949 \\
\hline
\end{tabular}


TABELA 4 a 10 - Análise intra-examinador da precisão da metodologia empregada: apresentação dos erros casuais de DAHLBERG ${ }^{27}$, das médias, dos desvios padrão (D.P.) das diferenças e nível de significância estatística dos erros sistemáticos, entre a primeira e a segunda medição dos traçados das radiografias. Houve apenas diferenças estatisticamente significantes, para o teste t, para duas variáveis, ao nível de $p<0,05$.

TABELA 4 - Análise intra-examinador da precisão da metodologia empregada: apresentação dos erros casuais de DAHLBERG ${ }^{27}$, das médias, dos desvios padrão (D.P.) das diferenças e nível de significância estatística dos erros sistemáticos, entre a primeira e a segunda medição dos traçados da Radiografia Submentoniana - Sistema de Coordenadas Mandibulares

\begin{tabular}{|l|r|r|r|r|}
\hline \multicolumn{5}{|c|}{ ÂNTERO-POSTERIOR } \\
\hline \multicolumn{1}{|c|}{ Variáveis } & DAHLBERG & $\begin{array}{c}\text { MÉDIA } \\
\text { DIFERENÇA }\end{array}$ & $\begin{array}{c}\text { D.P. } \\
\text { DIFERENÇA }\end{array}$ & p \\
\hline GO-ETC & 0,53 & 0,28 & 1,09 & 0,440500 \\
\hline PPC-ETC & 0,79 & $-0,16$ & 1,65 & 0,767104 \\
\hline PDMI-ETC & 0,55 & $-0,52$ & 1,04 & 0,150181 \\
\hline PDMS-ETC & 0,33 & 0,39 & 0,57 & 0,061728 \\
\hline \multicolumn{5}{|c|}{ TRANSVERSAL } \\
\hline GO-EIC & 1,68 & $-0,79$ & 3,45 & 0,488112 \\
\hline PPC-EIC & 1,38 & $-1,05$ & 2,7 & 0,250744 \\
\hline PDMI-EIC & 1,60 & 0,06 & 3,38 & 0,956474 \\
\hline PDMS-EIC & 1,51 & $-0,65$ & 3,12 & 0,526917 \\
\hline LMM-EIC & 0,93 & $-0,38$ & 1,92 & 0,548932 \\
\hline LMDI-EIC & 0,91 & $-0,40$ & 1,88 & 0,519814 \\
\hline LMDS-EIC & 0,87 & $-0,59$ & 1,74 & 0,312850 \\
\hline
\end{tabular}


TABELA 5 - Análise intra-examinador da precisão da metodologia empregada: apresentação dos erros casuais de DAHLBERG ${ }^{27}$, das médias, dos desvios padrão (D.P.) das diferenças e nível de significância estatística dos erros sistemáticos, entre a primeira e a segunda medição dos traçados da Radiografia Submentoniana - Sistema de Coordenadas do Assoalho Craniano

\begin{tabular}{|l|r|r|r|r|}
\hline \multicolumn{5}{|c|}{ ANTERO-POSTERIOR } \\
\hline \multicolumn{1}{|c|}{ Variáveis } & DAHLBERG & $\begin{array}{c}\text { MEDIA } \\
\text { DIFERENÇA }\end{array}$ & $\begin{array}{c}\text { D.P. } \\
\text { DIFERENÇA }\end{array}$ & p \\
\hline PCM-ETE & 0,56 & $-0,06$ & 1,18 & 0,876548 \\
\hline GO-ETE & 0,70 & 0,27 & 1,46 & 0,574963 \\
\hline PPC-ETE & 0,41 & 0,32 & 0,81 & 0,245682 \\
\hline PDMI-ETE & 0,53 & $-0,17$ & 1,11 & 0,641684 \\
\hline PDMS-ETE & 0,45 & $-0,24$ & 0,93 & 0,436091 \\
\hline \multicolumn{5}{|c|}{ TRANSVERSAL } \\
\hline PCM-EIE & 0,42 & 0,25 & 0,85 & 0,380167 \\
\hline GO-EIE & 0,63 & $-0,06$ & 1,33 & 0,889921 \\
\hline PPC-EIE & 0,52 & 0,02 & 1,11 & 0,955980 \\
\hline PDMI-EIE & 0,68 & 0,78 & 1,17 & 0,065115 \\
\hline PDMS-EIE & 0,62 & 0,06 & 1,32 & 0,888952 \\
\hline LMM-EIE & 0,50 & 0,17 & 1,05 & 0,623705 \\
\hline LMDI-EIE & 0,37 & $-0,08$ & 0,78 & 0,755244 \\
\hline LMDS-EIE & 0,30 & 0,08 & 0,63 & 0,699114 \\
\hline
\end{tabular}

TABELA 6 - Análise intra-examinador da precisão da metodologia empregada: apresentação dos erros casuais de DAHLBERG ${ }^{27}$, das médias, dos desvios padrão (D.P.) das diferenças e nível de significância estatística dos erros sistemáticos, entre a primeira e a segunda medição dos traçados da Radiografia Submentonia - Sistema de Coordenadas Zigomaticomaxilares

\begin{tabular}{|l|r|r|r|r|}
\hline \multicolumn{5}{|c|}{ ANTERO-POSTERIOR } \\
\hline Variáveis & DAHLBERG & $\begin{array}{c}\text { MEDIA } \\
\text { DIFERENÇA }\end{array}$ & $\begin{array}{c}\text { D.P. } \\
\text { DIFERENÇA }\end{array}$ & p \\
\hline PDMI-ETPTM & 0,85 & $-0,91$ & 1,52 & 0,092161 \\
\hline PDMS-ETPTM & 0,70 & 0,10 & 1,47 & 0,835348 \\
\hline \multicolumn{5}{|c|}{ TRANSVERSAL } \\
\hline VA-EIPTM & 0,43 & $-0,13$ & 0,91 & 0,663559 \\
\hline VP-EIPTM & 0,31 & $-0,33$ & 0,57 & 0,102209 \\
\hline PDMI-EIPTM & 0,86 & 1,16 & 1,34 & 0,023272 \\
\hline PDMS-EIPTM & 0,79 & 0,70 & 1,50 & 0,176318 \\
\hline LMDS-EIPTM & 0,76 & 0,80 & 1,38 & 0,100838 \\
\hline LMM-EIPTM & 0,72 & 1,05 & 1,05 & 0,011812 \\
\hline LMDI-EIPTM & 0,66 & $-0,06$ & 1,39 & 0,895013 \\
\hline
\end{tabular}


TABELA 7 - Análise intra-examinador da precisão da metodologia empregada: apresentação dos erros casuais de DAHLBERG ${ }^{27}$, das médias, dos desvios padrão (D.P.) das diferenças e nível de significância estatística dos erros sistemáticos, entre a primeira e a segunda medição dos traçados da Radiografia Submentoniana - Sistema de Coordenadas Dentárias

\begin{tabular}{|l|r|r|r|r|}
\hline \multicolumn{5}{|c|}{ TRANSVERSAL } \\
\hline Variáveis & DAHLBERG & $\begin{array}{c}\text { MEDIA } \\
\text { DIFERENÇA }\end{array}$ & $\begin{array}{c}\text { D.P. } \\
\text { DIFERENÇA }\end{array}$ & p \\
\hline LMDI-EIMI & 0,37 & $-0,04$ & 0,78 & 0,874851 \\
\hline LMM-EIMI & 0,50 & 0,41 & 0,96 & 0,213177 \\
\hline LMDS-EIMI & 0,55 & 0,13 & 1,15 & 0,729609 \\
\hline LMDI-EIMS & 0,45 & $-0,35$ & 0,88 & 0,241866 \\
\hline LMDS-EIMS & 0,40 & $-0,06$ & 0,85 & 0,829395 \\
\hline LMM-EIMS & 0,42 & 0,23 & 0,86 & 0,421783 \\
\hline
\end{tabular}

TABELA 8 - Análise intra-examinador da precisão da metodologia empregada: apresentação dos erros casuais de DAHLBERG ${ }^{27}$, das médias, dos desvios padrão (D.P.) das diferenças e nível de significância estatística dos erros sistemáticos, entre a primeira e a segunda medição dos traçados da Radiografia Submentoniana - Medidas Angulares

\begin{tabular}{|l|r|r|r|r|}
\hline \multicolumn{1}{|c|}{ Variáveis } & DAHLBERG & $\begin{array}{c}\text { MEDIA } \\
\text { DIFERENÇA }\end{array}$ & $\begin{array}{c}\text { D.P. } \\
\text { DIFERENÇA }\end{array}$ & \multicolumn{1}{c|}{ p } \\
\hline EIE-EIC & 0,27 & $-0,09$ & 0,56 & 0,627495 \\
\hline ETE-ETC & 0,30 & $-0,04$ & 0,64 & 0,848476 \\
\hline ETPTM-ETC & 0,33 & $-0,21$ & 0,66 & 0,344588 \\
\hline ETPTM-ETE & 0,56 & 0,24 & 1,15 & 0,527526 \\
\hline ETMI-ETE & 0,54 & $-0,12$ & 1,13 & 0,746224 \\
\hline ETMI-ETC & 0,58 & $-0,54$ & 1,08 & 0,150809 \\
\hline ETMI-ETPTM & 0,88 & $-0,95$ & 1,57 & 0,089190 \\
\hline ETMS-ETE & 0,47 & $-0,22$ & 0,97 & 0,491630 \\
\hline ETMS-ETC & 0,36 & 0,42 & 0,63 & 0,064379 \\
\hline ETMS-ETPTM & 0,75 & 0,15 & 1,58 & 0,771604 \\
\hline
\end{tabular}


TABELA 9 - Análise intra-examinador da precisão da metodologia empregada: apresentação dos erros casuais de DAHLBERG ${ }^{27}$, das médias, dos desvios padrão (D.P.) das diferenças e nível de significância estatística dos erros sistemáticos, entre a primeira e a segunda medição dos traçados da Radiografia Submentoniana - Variáveis Adicionais

\begin{tabular}{|l|r|r|r|r|}
\hline \multicolumn{1}{|c|}{ Variáveis } & \multicolumn{1}{c|}{ DAHLBERG } & $\begin{array}{c}\text { MÉDIA } \\
\text { DIFERENÇA }\end{array}$ & $\begin{array}{c}\text { D.P. } \\
\text { DIFERENÇA }\end{array}$ & \multicolumn{1}{c|}{ p } \\
\hline PCM-LMM & 0,44 & 0,17 & 0,92 & 0,577330 \\
\hline PCM-CMM & 0,83 & $-0,06$ & 1,76 & 0,916643 \\
\hline POSM & 0,46 & 0,37 & 0,90 & 0,229701 \\
\hline POSMS & 0,35 & $-0,15$ & 0,72 & 0,529064 \\
\hline
\end{tabular}

TABELA 10 - Análise intra-examinador da precisão da metodologia empregada: apresentação dos erros casuais de DAHLBERG ${ }^{27}$, das médias, dos desvios padrão (D.P.) das diferenças e nível de significância estatística dos erros sistemáticos, entre a primeira e a segunda medição dos traçados da Radiografia Póstero-Anterior

\begin{tabular}{|l|r|r|r|r|}
\hline \multicolumn{1}{|c|}{ Variáveis } & DAHLBERG & $\begin{array}{c}\text { MEDIA } \\
\text { DIFERENÇA }\end{array}$ & $\begin{array}{c}\text { D.P. } \\
\text { DIFERENÇA }\end{array}$ & \multicolumn{1}{c|}{$\mathbf{p}$} \\
\hline ÂPLANOZ & 0,42 & $-0,01$ & 0,90 & 0,972773 \\
\hline ÂPLOCLUSAL & 0,58 & $-0,04$ & 1,24 & 0,921002 \\
\hline ÂPLANTEG & 1,44 & $-0,40$ & 3,01 & 0,684565 \\
\hline DESVENA & 0,43 & 0,12 & 0,91 & 0,688461 \\
\hline DESMAND & 0,89 & $-0,01$ & 1,88 & 0,987004 \\
\hline A1 & 0,59 & 0,02 & 1,25 & 0,960799 \\
\hline B1 & 0,45 & $-0,31$ & 0,91 & 0,310492 \\
\hline ÂANT & 0,99 & 0,62 & 2,00 & 0,352906 \\
\hline DISTZ & 0,82 & $-0,13$ & 1,72 & 0,817308 \\
\hline DISTCO & 2,32 & 0,08 & 4,89 & 0,959897 \\
\hline DISTZA & 2,41 & 0,22 & 5,08 & 0,894275 \\
\hline DISTNC & 1,37 & 0,19 & 2,88 & 0,839557 \\
\hline DISTJ & 1,44 & 0,29 & 3,03 & 0,769755 \\
\hline DISTAG & 2,10 & 0,02 & 4,44 & 0,988965 \\
\hline ALT6 & 1,13 & 0,31 & 2,36 & 0,688470 \\
\hline C0-AG & 1,92 & 0,38 & 4,03 & 0,772522 \\
\hline CO-ME & 1,11 & 0,17 & 2,34 & 0,824131 \\
\hline ME-AG & 1,80 & 0,37 & 3,79 & 0,764636 \\
\hline
\end{tabular}


TABELA 11 - Resultado do Teste de Correlação de Pearson ( $r$ ) entre as assimetrias da Radiografia Submentoniana - Sistema de Coordenadas Mandibulares e as assimetrias da Fotografia Frontal para os grupos 1 (42 pacientes com Classe II, subdivisão), 2 (25 pacientes com Classe II, subdivisão, tipo 1) e 3 (8 pacientes com Classe II, subdivisão, tipo 2)

\begin{tabular}{|c|c|c|c|c|c|c|c|c|c|}
\hline \multicolumn{10}{|c|}{ MEDIDAS DE PROPORÇÃO-FOTOGRAFIA } \\
\hline \multicolumn{10}{|c|}{ ÂNTERO-POSTERIOR } \\
\hline \multirow[t]{2}{*}{ Variáveis } & \multicolumn{3}{|c|}{\begin{tabular}{|l|} 
ZyDMe/ZYEMe \\
\end{tabular}} & \multicolumn{3}{|c|}{ GoDMe/GoEMe } & \multicolumn{3}{|c|}{ ZyDGoD/ZYEGoE } \\
\hline & G1 & G 2 & G 3 & G 1 & G 2 & G 3 & G1 1 & G 2 & \begin{tabular}{l|l} 
G 3 \\
\end{tabular} \\
\hline GO-ETC & 0,04 & 0,13 & $-0,15$ & 0,20 & 0,36 & 0,04 & 0,24 & 0,35 & 0,13 \\
\hline PPC-ETC & $-0,28$ & $-0,26$ & 0,01 & $-0,28$ & $-0,14$ & $-0,36$ & $-0,21$ & $-0,14$ & $-0,26$ \\
\hline \multicolumn{10}{|c|}{ TRANSVERSAL } \\
\hline GO-EIC & $-0,05$ & $-0,20$ & $-0,41$ & 0,07 & 0,04 & $-0,55$ & 0,08 & 0,08 & $-0,58$ \\
\hline PPC-EIC & 0,02 & $-0,06$ & 0,51 & $-0,11$ & $-0,25$ & 0,39 & 0,00 & $-0,14$ & 0,57 \\
\hline LMM-EIC & 0,22 & \multirow{2}{*}{0,30} & 0,86 & $-0,05$ & $-0,07$ & 0,54 & 0,04 & 0,04 & 0,69 \\
\hline LMDI-EIC & 0,25 & & 0,57 & 0,14 & 0,37 & 0,36 & 0,16 & 0,29 & 0,55 \\
\hline LMDS-EIC & 0,23 & 0.09 & 0,75 & 0,04 & $-0,10$ & 0,71 & 0,14 & 0,06 & 0,89 \\
\hline \multicolumn{10}{|c|}{ MEDIDAS DE ESTRUTURAS CENTRAIS - FOTOGRAFIA } \\
\hline & & & ANTERC & D-POS1 & TERI & & & & \\
\hline Variáveis & & & Me & & & & Sbn & & \\
\hline & G1 & & G 2 & G 3 & & G 1 & G 2 & & G 3 \\
\hline GO-ETC & & 06 & 0,16 & &, 27 & 0,22 & & ,22 & 0,24 \\
\hline PPC-ETC & & 12 & $-0,20$ & & 12 & 0,01 & & 12 & 0,73 \\
\hline & & & TRAI & JSVER & SAL & & & & \\
\hline GO-EIC & & 11 & 0,11 & & 10 & $-0,00$ & &, 10 & 0,53 \\
\hline PPC-EIC & & 03 & $-0,09$ & & 45 & $-0,07$ & & 04 & $-0,74$ \\
\hline LMM-EIC & & 07 & $-0,42$ & & 74 & $-0,22$ & & ,23 & $-0,79$ \\
\hline LMDI-EIC & & 06 & $-0,27$ & & 44 & $-0,19$ & &, 15 & $-0,54$ \\
\hline LMDS-EIC & & 03 & $-0,10$ & &, 38 & $-0,17$ & & 07 & $-0,55$ \\
\hline
\end{tabular}

$\mathrm{p}<0,05$ 
TABELA 12 - Resultado do Teste de Correlação de Pearson ( $r$ ) entre as assimetrias da Radiografia Submentoniana - Sistema de Coordenadas do Assoalho Craniano e as assimetrias da Fotografia Frontal para os grupos 1 (42 pacientes com Classe II, subdivisão), 2 (25 pacientes com Classe II, subdivisão, tipo 1) e 3 (8 pacientes com Classe II, subdivisão, tipo 2)

\begin{tabular}{|c|c|c|c|c|c|c|c|c|c|}
\hline \multicolumn{10}{|c|}{ MEDIDAS DE PROPORÇÃO - FOTOGRAFIA } \\
\hline \multicolumn{10}{|c|}{ ÂNTERO-POSTERIOR } \\
\hline \multirow[t]{2}{*}{ Variáveis } & \multicolumn{3}{|c|}{ ZyDMe/ZYEMe } & \multicolumn{3}{|c|}{ GoDMe/GoEMe } & \multicolumn{3}{|c|}{ ZyDGoD/ZYEGoE } \\
\hline & \multirow{2}{*}{$\begin{array}{c}\mathbf{G ~ 1} \\
-0.07\end{array}$} & G 2 & G 3 & $\begin{array}{ll}\text { G1 } \\
\end{array}$ & G 2 & G 3 & G1 & G 2 & \begin{tabular}{l|l}
$\mathbf{G} 3$ \\
\end{tabular} \\
\hline PCM-ETE & & \multirow{2}{*}{$-0,01$} & $-0,14$ & $-0,07$ & $-0,14$ & 0,21 & $-0,13$ & $-0,22$ & 0,29 \\
\hline GO-ETE & $\begin{array}{r}-0,07 \\
0,07\end{array}$ & & $-0,41$ & 0,23 & 0,24 & 0,19 & 0,17 & 0,17 & 0,11 \\
\hline PPC-ETE & $-0,16$ & $-0,11$ & 0,02 & $-0,17$ & -0, & 0,10 & $-0,15$ & $-0,1$ & 0,14 \\
\hline \multicolumn{10}{|c|}{ TRANSVERSAL } \\
\hline PCM-EIE & $-0,05$ & \multirow{2}{*}{$\begin{array}{l}-0,19 \\
-0,27\end{array}$} & 0,25 & \begin{tabular}{|c|c|}
$-0,06$ \\
\end{tabular} & $-0,13$ & $-0,10$ & $-0,03$ & $-0,10$ & 0,02 \\
\hline GO-EIE & \multirow{2}{*}{$-0,02$} & & $-0,03$ & 0,06 & $-0,02$ & $-0,46$ & 0,03 & $-0,04$ & $-0,44$ \\
\hline PPC-EIE & & $-0,20$ & 0,31 & $-0,17$ & -0 & $-0,04$ & $-0,06$ & $-0,1$ & 0,21 \\
\hline LMM-EIE & 0,14 & 0,20 & 0,66 & $-0,08$ & -0, & 0,30 & $-0,06$ & $-0,1$ & 0,44 \\
\hline LMDI-EIE & $-0,00$ & 0,02 & 0,32 & $-0,09$ & -0, & 0,22 & $-0,12$ & $-0,1$ & 0,35 \\
\hline LMDS-EIE & 0,18 & 0,14 & 0,59 & 0,07 & 0, & 0,42 & 0,13 & 0,0 & 0,70 \\
\hline & DAS & 5 & ארו & L & IV & -1 & U & & \\
\hline & & & ANTERC & & IN & & & & \\
\hline Variáveis & & & Me & & & & Sbn & & \\
\hline & & 1 & G 2 & G 3 & & G 1 & G 2 & & G 3 \\
\hline PCM-ETE & & 0,00 & $-0,03$ & & 46 & $-0,26$ & & 35 & 0,16 \\
\hline GO- & & 0,15 & $-0,05$ & & 36 & $-0,16$ & & 30 & $-0,22$ \\
\hline PPC-ETE & & 0,23 & $-0,16$ & & 19 & $-0,07$ & &, 13 & $-0,13$ \\
\hline & & & TRAI & ISVER & SAL & & & & \\
\hline PCM-EIE & & 0,04 & 0,08 & & 28 & 0,04 & $-0,0$ & & 0,34 \\
\hline GO-EIE & & 0,03 & 0,11 & & 17 & 0,13 & 0,1 & & 0,6 \\
\hline PPC-EIE & & 0,04 & $-0,29$ & & 25 & $-0,05$ & $-0,1$ & & 0,0 \\
\hline LMM-EIE & & 0,20 & $-0,29$ & &, 58 & $-0,17$ & $-0,1$ & & $-0,56$ \\
\hline LMDI-EIE & & 0,13 & $-0,31$ & & 19 & $-0,18$ & $-0,0$ & & $-0,36$ \\
\hline LMDS-EIE & & 0,08 & $-0,11$ & & 32 & $-0,07$ & 0,0 & & $-0,43$ \\
\hline
\end{tabular}

$\mathrm{p}<0,05$ 
TABELA 13 - Resultado do Teste de Correlação de Pearson entre as assimetrias da Radiografia Submentoniana - Sistema de Coordenadas Zigomaticomaxilares e as assimetrias da Fotografia Frontal para os grupos 1 (42 pacientes com Classe II, subdivisão), 2 (25 pacientes com Classe II, subdivisão, tipo 1) e 3 (8 pacientes com Classe II, subdivisão, tipo 2)

\begin{tabular}{|c|c|c|c|c|c|c|c|c|c|}
\hline \multicolumn{10}{|c|}{ MEDIDAS DE PROPORÇÃO - FOTOGRAFIA } \\
\hline \multicolumn{10}{|c|}{$\begin{array}{l}\text { TRANSVERSAL } \\
\end{array}$} \\
\hline \multirow[t]{2}{*}{ Variáveis } & \multicolumn{3}{|c|}{ ZyDMe/ZYEMe } & \multicolumn{3}{|c|}{ GoDMe/GoEMe } & \multicolumn{3}{|c|}{ ZyDGoD/ZYEGoE } \\
\hline & G1 1 & $\mathbf{G} 2$ & G 3 & G1 & $\mathbf{G} 2$ & G 3 & $\mathbf{G} 1$ & $\frac{G 121}{G 2}$ & G 3 \\
\hline LMDS-EIPTM & 0,03 & $-0,01$ & 0,21 & 0.19 & 0,13 & 0,76 & 016 & 0,05 & 0,80 \\
\hline & 0,05 & 0,16 & 0,49 & 0,07 & 0,28 & 0,60 & 0,03 & 0,19 & 0,7 \\
\hline DTM & & 0,43 & 0,15 & 0,15 & 0,38 & 0,01 & 0,22 & 0,46 & 0,1 \\
\hline \multicolumn{10}{|c|}{ MEDIDAS DE ESTRUTURAS CENTRAIS- FOTOGRAFIA } \\
\hline \multicolumn{10}{|c|}{ TRANSVERSAL } \\
\hline \multirow{2}{*}{\multicolumn{2}{|c|}{ Variáveis }} & \multicolumn{4}{|c|}{ Me } & \multicolumn{4}{|c|}{ Sbn } \\
\hline & & G1 & G 2 & $\mathbf{G}$ & 3 & G1 & G & 2 & $\mathbf{G} 3$ \\
\hline LMDS & & $-0,22$ & 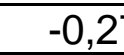 & & 0,33 & $-0,1$ & & 0,00 & $-0,4$ \\
\hline LMM-EIPTM & & 0,17 & $-0,2$ & & 0,24 & $-0,1$ & & 0,19 & $-0,7$ \\
\hline LMDI-EIPTM & & 0,05 & $-0,2$ & & 0,01 & $-0,2$ & & 0,28 & $-0,0$ \\
\hline
\end{tabular}
$p<0,05$

TABELA 14 - Resultado do Teste de Correlação de Pearson (r) entre as assimetrias da Radiografia Submentoniana - Variáveis Adicionais e as assimetrias Fotografia Frontal para os grupos 1 (42 pacientes com Classe II, subdivisão), 2 (25 pacientes com Classe II, subdivisão, tipo 1) e 3 (8 pacientes com Classe II, subdivisão, tipo 2)

\begin{tabular}{|c|c|c|c|c|c|c|c|c|c|}
\hline \multicolumn{10}{|c|}{ MEDIDAS DE PROPORCCÃO - FOTOGRAFIA } \\
\hline \multirow[t]{2}{*}{ Variáveis } & \multicolumn{3}{|c|}{ ZyDMe/ZYEMe } & \multicolumn{3}{|c|}{ GoDMe/GoEMe } & \multicolumn{3}{|c|}{ ZvDGoD/ZYEGoE } \\
\hline & G1 & G 2 & G 3 & G1 & G 2 & $\mathbf{G} 3$ & \begin{tabular}{l|l}
1 \\
\end{tabular} & G 2 & G 3 \\
\hline PCM-LMM & 0,18 & 0,19 & 0,79 & $-0,06$ & $-0,1$ & 0,47 & 0,00 & $-0,09$ & 0,64 \\
\hline PCM-CMM & 0,14 & 0,19 & $-0,46$ & 0,15 & 0,0 & $-0,37$ & 0,10 & $-0,07$ & $-0,41$ \\
\hline \multicolumn{10}{|c|}{ MEDIDAS DE ESTRUTURAS CENTRAIS - FOTOGRAFIA } \\
\hline \multirow[t]{2}{*}{ Variáveis } & \multicolumn{5}{|c|}{ Me } & \multicolumn{4}{|c|}{ Sbn } \\
\hline & & 1 & $\mathbf{G} 2$ & G: & & G 1 & G 2 & & G 3 \\
\hline PCM-LMM & & 0,04 & $-0,40$ & &, 75 & $-0,22$ & $-0,26$ & & $-0,78$ \\
\hline PCM-CMM & & 0,15 & $-0,12$ & &, 37 & $-0,07$ & $-0,15$ & & 0,19 \\
\hline
\end{tabular}

$\mathrm{p}<0,05$ 
TABELA 15 - Resultado do Teste de Correlação de Pearson entre as assimetrias da Radiografia Póstero-Anterior e as assimetrias da Fotografia Frontal para os grupos 1 (42 pacientes com Classe II, subdivisão), 2 (25 pacientes com Classe II, subdivisão, tipo 1) e 3 (8 pacientes com Classe II, subdivisão, tipo 2)

\begin{tabular}{|c|c|c|c|c|c|c|c|c|c|}
\hline \multicolumn{10}{|c|}{ MEDIDAS DE PROPORÇÃO - FOTOGRAFIA } \\
\hline \multirow[t]{2}{*}{ Variáveis } & \multicolumn{3}{|c|}{ ZyDMe/ZYEMe } & \multicolumn{3}{|c|}{ GoDMe/GoEMe } & \multicolumn{3}{|c|}{ ZyDGoD/ZYEGoE } \\
\hline & G1 & G 2 & G 3 & \multicolumn{2}{|c|}{\begin{tabular}{l|l} 
G 1 & G 2 \\
\end{tabular}} & $\mathbf{G} 3$ & G1 & G2 & \multirow{2}{*}{\begin{tabular}{|c|} 
G 3 \\
$-0,51$
\end{tabular}} \\
\hline ÂPLANOZ & \multirow{2}{*}{$\begin{array}{l}0,09 \\
0,20\end{array}$} & 0,32 & $-0,36$ & 0,18 & 0,47 & $-0,37$ & 0,14 & \multirow{2}{*}{$\frac{0,45}{0,31}$} & \\
\hline ÂPLOCLUSAL & & \multirow{2}{*}{$\frac{0,34}{0,14}$} & 0,21 & 0,27 & 0,44 & $-0,04$ & 0,20 & & $-0,05$ \\
\hline ÂPLANTEG & \multirow{2}{*}{0,10} & & 0,06 & 0,21 & 0,20 & 0,24 & 0,21 & 0,20 & 0,23 \\
\hline DESVENA & & $-0,41$ & $-0,60$ & $-0,47$ & $-0,47$ & $-0,88$ & $-0,45$ & $-0,52$ & $-0,75$ \\
\hline DESMAND & $-0,02$ & 0,12 & $-0,56$ & $-0,16$ & 0,01 & $-0,18$ & $-0,16$ & 0,02 & $-0,37$ \\
\hline A1 & $-0,30$ & $-0,28$ & $-0,55$ & $-0,35$ & $-0,36$ & $-0,18$ & $-0,39$ & $-0,47$ & $-0,19$ \\
\hline B1 & $-0,02$ & 0,15 & $-0,34$ & $-0,13$ & 0,02 & $-0,14$ & $-0,08$ & 0,09 & $-0,14$ \\
\hline ÂANT & $-0,04$ & 0,20 & $-0,36$ & 0,02 & 0,31 & $-0,47$ & $-0,03$ & 0,22 & $-0,53$ \\
\hline DISTZ & 0,01 & 0,11 & 0,42 & $-0,17$ & $-0,06$ & 0,07 & $-0,09$ & 0,01 & 0,07 \\
\hline DISTCO & 0,14 & 0,09 & 0,42 & 0,00 & $-0,02$ & 0,08 & 0,05 & $-0,02$ & 0,10 \\
\hline DISTZA & 0,04 & 0,09 & $-0,04$ & 0,06 & $0,1 \mathrm{~s}$ & $-0,34$ & 0,01 & 0,04 & $-0,40$ \\
\hline DISTNC & $-0,25$ & $-0,25$ & $-0,36$ & $-0,38$ & $-0,37$ & $-0,72$ & $-0,38$ & $-0,43$ & $-0,69$ \\
\hline DISTJ & $-0,24$ & $-0,22$ & $-0,39$ & $-0,33$ & $-0,2$ & \begin{tabular}{|c|}
$-0,74$ \\
\end{tabular} & $-0,26$ & $-0,24$ & $-0,77$ \\
\hline DISTAG & 0,08 & $-0,04$ & 0,23 & $-0,01$ & $-0,03$ & 0,07 & $-0,03$ & $-0,11$ & $-0,00$ \\
\hline C0-AG & $-0,04$ & 0,23 & $-0,48$ & $-0,17$ & 0,11 & $-0,68$ & $-0,11$ & 0,14 & $-0,69$ \\
\hline CO-ME & 0,02 & 0,02 & 0,64 & $-0,09$ & $-0,15$ & 0,84 & $-0,07$ & $-0,06$ & 0,70 \\
\hline ME-AG & $-0,16$ & $-0,07$ & $-0,20$ & $-0,02$ & 0,12 & $-0,11$ & $-0,11$ & $-0,00$ & $-0,15$ \\
\hline MEDII & AS DE & ESTF & RUTURA & S CEN & VTRA & -FOTC & OGRAF & & \\
\hline Variáveis & & & Me & & & & Sbn & & \\
\hline & G 1 & & G 2 & G 3 & & G 1 & G 2 & & G 3 \\
\hline ÂPLANOZ & & 0,14 & 0,19 & & 0,20 & $\begin{array}{l}-0,32 \\
\end{array}$ & $-0,2$ & & 0,13 \\
\hline ÂPLOCLUSAL & & 0,07 & 0,26 & & 0,31 & $-0,09$ & $-0,0$ & & $-0,19$ \\
\hline ÂPLANTEG & & 0,03 & 0,20 & & 0,08 & $-0,13$ & $-0,1$ & & $-0,43$ \\
\hline DESVENA & & $-0,10$ & $-0,14$ & & 0,09 & 0,46 & 0,4 & 45 & 0,55 \\
\hline DESMAND & & 0,14 & 0,21 & & 0,35 & $-0,08$ & 0,0 & 03 & 0,24 \\
\hline A1 & & $-0,09$ & $-0,01$ & & , ,73 & 0,40 & 0,3 & 36 & 0,67 \\
\hline B1 & & 0,06 & 0,08 & & 0,53 & $-0,11$ & $-0,1$ & & 0,17 \\
\hline ÂANT & & 0,30 & 0,21 & & 0,07 & 0,29 & 0,4 & 43 & 0,32 \\
\hline DISTZ & & $-0,08$ & $-0,19$ & & 0,44 & 0,25 & 0,3 & 35 & $-0,05$ \\
\hline DISTCO & & $-0,11$ & $-0,09$ & & 0,66 & 0,14 & 0,1 & 16 & $-0,62$ \\
\hline DISTZA & & $-0,10$ & 0,14 & & 0,03 & 0,39 & 0,3 & 38 & 0,18 \\
\hline DISTNC & & $-0,16$ & $-0,07$ & & 0,39 & 0,33 & 0,2 & 29 & 0,22 \\
\hline DISTJ & & $-0,12$ & $-0,00$ & & 0,29 & 0,42 & 0,4 & 41 & 0,34 \\
\hline DISTAG & & $-0,06$ & 0,13 & & 0,36 & 0,19 & 0,3 & 32 & $-0,28$ \\
\hline C0-AG & & $-0,09$ & $-0,21$ & & 0,18 & $-0,18$ & $-0,4$ & 47 & 0,69 \\
\hline CO-ME & & 0,10 & $-0,01$ & & 0,07 & $-0,20$ & $-0,1$ & & $-0,63$ \\
\hline ME-AG & & 0,31 & 0,34 & & 0,05 & $-0,03$ & $-0,0$ & 01 & 0,13 \\
\hline
\end{tabular}

$p<0,05$ 
TABELA 16 a 22 - Resultados do teste $t$ independente, entre os grupos de oclusão normal e de Classe II, subdivisão com assimetria facial aparente.

TABELA 16 - Resultados do teste t independente, entre os grupos de oclusão normal e de Classe II, subdivisão com assimetria facial aparente. Radiografia Submentoniana - Sistema de Coordenadas Mandibulares

\begin{tabular}{|l|c|c|c|c|c|c|c|}
\hline \multicolumn{7}{|c|}{ ANTERO - POSTERIOR } \\
\hline Variáveis & $\begin{array}{c}\text { Média } \\
\text { Oclusão } \\
\text { Normal }\end{array}$ & $\begin{array}{c}\text { D.P. } \\
\text { Oclusão } \\
\text { Normal }\end{array}$ & $\begin{array}{c}\text { Média } \\
\text { Classe II, } \\
\text { subdivisão }\end{array}$ & $\begin{array}{c}\text { D.P. } \\
\text { Classe II, } \\
\text { subdivisão }\end{array}$ & $\begin{array}{c}\text { Valor } \\
\mathbf{t}\end{array}$ & $\mathbf{g I}$ & $\mathbf{p}$ \\
\hline GO-ETC & 1,21 & 1,22 & 1,54 & 0,99 & $-1,03$ & 51 & 0,303294 \\
\hline PPC-ETC & 1,32 & 0,85 & 1,30 & 1,06 & 0,05 & 51 & 0,952833 \\
\hline PDMI-ETC & 0,96 & 0,64 & 2,79 & 1,34 & $-6,56$ & 51 & 0,000000 \\
\hline PDMS-ETC & 0,96 & 0,72 & 1,39 & 1,02 & $-1,78$ & 51 & 0,079855 \\
\hline \multicolumn{7}{|c|}{ TRANSVERSAL } \\
\hline GO-EIC & 1,95 & 1,25 & 2,63 & 2,62 & $-1,24$ & 51 & 0,220317 \\
\hline PPC-EIC & 2,58 & 1,82 & 2,21 & 1,76 & 0,73 & 51 & 0,465053 \\
\hline PDMI-EIC & 2,94 & 2,04 & 3,69 & 3,17 & $-1,04$ & 51 & 0,299682 \\
\hline PDMS-EIC & 2,69 & 1,84 & 3,26 & 2,81 & $-0,89$ & 51 & 0,373037 \\
\hline LMM-EIC & 1,88 & 1,50 & 3,09 & 2,87 & $-1,97$ & 51 & 0,053683 \\
\hline LMDI-EIC & 1,72 & 1,24 & 2,59 & 2,00 & $-1,93$ & 51 & 0,058396 \\
\hline LMDS-EIC & 1,55 & 1,12 & 1,88 & 1,85 & $-0,80$ & 51 & 0,426126 \\
\hline
\end{tabular}

TABELA 17 - Resultados do teste t independente, entre os grupos de oclusão normal e de Classe II, subdivisão com assimetria facial aparente. Radiografia Submentoniana - Sistema de Coordenadas do Assoalho Craniano

\begin{tabular}{|l|c|c|c|c|c|c|c|}
\hline \multicolumn{7}{|c|}{ ÁNTERO - POSTERIOR } \\
\hline Variáveis & $\begin{array}{c}\text { Média } \\
\text { Oclusão } \\
\text { Normal }\end{array}$ & $\begin{array}{c}\text { D.P. } \\
\text { Oclusão } \\
\text { Normal }\end{array}$ & $\begin{array}{c}\text { Média } \\
\text { Classe II, } \\
\text { subdivisão }\end{array}$ & $\begin{array}{c}\text { D.P. } \\
\text { Classe II, } \\
\text { subdivisão }\end{array}$ & $\begin{array}{c}\text { Valor } \\
\text { t }\end{array}$ & gl & P \\
\hline PCM-ETE & 1,59 & 1,27 & 1,37 & 0,76 & 0,72 & 51 & 0,470861 \\
\hline GO-ETE & 1,63 & 1,42 & 2,03 & 1,11 & $-1,12$ & 51 & 0,265905 \\
\hline PPC-ETE & 1,68 & 1,28 & 2,01 & 1,24 & $-0,94$ & 51 & 0,346981 \\
\hline PDMI-ETE & 1,04 & 0,84 & 2,95 & 1,27 & $-6,58$ & 51 & 0,000000 \\
\hline PDMS-ETE & 1,02 & 0,90 & 1,34 & 1,03 & $-1,20$ & 51 & 0,233172 \\
\hline \multicolumn{7}{|c|}{ TRANSVERSAL } \\
\hline PCM-EIE & 0,95 & 0,68 & 1,33 & 1,21 & $-1,46$ & 51 & 0,149076 \\
\hline GO-EIE & 1,78 & 1,31 & 2,81 & 2,57 & $-1,89$ & 51 & 0,063570 \\
\hline PPC-EIE & 2,74 & 1,92 & 2,60 & 1,64 & 0,28 & 51 & 0,777461 \\
\hline PDMI-EIE & 3,26 & 2,41 & 3,91 & 2,98 & $-0,87$ & 51 & 0,387934 \\
\hline PDMS-EIE & 2,86 & 2,15 & 3,48 & 2,70 & $-0,92$ & 51 & 0,358155 \\
\hline LMM-EIE & 2,13 & 1,87 & 3,33 & 2,84 & $-1,84$ & 51 & 0,070210 \\
\hline LMDI-EIE & 1,90 & 1,67 & 2,61 & 2,31 & $-1,30$ & 51 & 0,196699 \\
\hline LMDS-EIE & 1,94 & 1,32 & 2,18 & 1,69 & $-0,58$ & 51 & 0,564126 \\
\hline
\end{tabular}


TABELA 18 - Resultados do teste t independente, entre os grupos de oclusão normal e de Classe II, subdivisão com assimetria facial aparente. Radiografia Submentonia - Sistema de Coordenadas Zigomaticomaxilares

\begin{tabular}{|l|c|c|c|c|c|c|c|}
\hline \multicolumn{7}{|c|}{ ANTERO-POSTERIOR } \\
\hline Variáveis & $\begin{array}{c}\text { Média } \\
\text { Oclusão } \\
\text { Normal }\end{array}$ & $\begin{array}{c}\text { D.P. } \\
\text { Oclusão } \\
\text { Normal }\end{array}$ & $\begin{array}{c}\text { Média } \\
\text { Classe II, } \\
\text { subdivisão }\end{array}$ & $\begin{array}{c}\text { D.P. } \\
\text { Classe II, } \\
\text { subdivisão }\end{array}$ & $\begin{array}{c}\text { Valor } \\
\mathbf{t}\end{array}$ & $\mathbf{g l}$ & $\mathbf{p}$ \\
\hline PDMI-ETPTM & 1,27 & 0,95 & 3,16 & 1,93 & $-4,68$ & 51 & 0,000021 \\
\hline PDMS-ETPTM & 1,23 & 0,90 & 1,13 & 0,94 & 0,39 & 51 & 0,691254 \\
\hline \multicolumn{7}{|c|}{ TRANSVERSAL } \\
\hline VA-EIPTM & 1,08 & 0,72 & 0,87 & 0,65 & 1,06 & 51 & 0,290060 \\
\hline VP-EIPTM & 0,64 & 0,56 & 0,55 & 0,48 & 0,63 & 51 & 0,5264333 \\
\hline PDMI-EIPTM & 2,52 & 2,66 & 3,21 & 2,44 & $-0,96$ & 51 & 0,337545 \\
\hline PDMS-EIPTM & 2,26 & 2,61 & 2,58 & 2,03 & $-0,49$ & 51 & 0,626220 \\
\hline LMDS-EIPTM & 1,82 & 1,85 & 1,93 & 1,52 & $-0,24$ & 51 & 0,804071 \\
\hline LMM-EIPTM & 1,94 & 1,92 & 3,15 & 2,65 & $-1,93$ & 51 & 0,059139 \\
\hline LMDI-EIPTM & 1,76 & 1,91 & 2,64 & 2,23 & $-1,54$ & 51 & 0,128990 \\
\hline
\end{tabular}

TABELA 19 - Resultados do teste t independente, entre os grupos de oclusão normal e de Classe II, subdivisão com assimetria facial aparente. Radiografia Submentoniana - Sistema de Coordenadas Dentárias

\begin{tabular}{|l|c|c|c|c|c|c|c|}
\hline \multicolumn{1}{|c|}{ Variáveis } & $\begin{array}{c}\text { Média } \\
\text { Oclusão } \\
\text { Normal }\end{array}$ & $\begin{array}{c}\text { D.P. } \\
\text { Oclusão } \\
\text { Normal }\end{array}$ & $\begin{array}{c}\text { Média } \\
\text { Classe II, } \\
\text { subdivisão }\end{array}$ & $\begin{array}{c}\text { D.P. } \\
\text { Classe II, } \\
\text { subdivisão }\end{array}$ & $\begin{array}{c}\text { Valor } \\
\mathbf{t}\end{array}$ & $\mathbf{g l}$ & $\mathbf{p}$ \\
\hline LMDI-EIMI & 0,63 & 0,52 & 1,07 & 0,96 & $-2,15$ & 51 & 0,035790 \\
\hline LMM-EIMI & 0,88 & 0,68 & 1,84 & 1,38 & $-3,31$ & 51 & 0,001716 \\
\hline LMDS-EIMI & 0,73 & 0,49 & 3,60 & 1,38 & $-10,57$ & 51 & 0,000000 \\
\hline LMDI-EIMS & 0,62 & 0,52 & 2,42 & 1,35 & $-6,67$ & 51 & 0,000000 \\
\hline LMDS-EIMS & 0,55 & 0,47 & 0,99 & 0,53 & $-3,19$ & 51 & 0,002398 \\
\hline LMM-EIMS & 0,89 & 0,74 & 2,47 & 1,88 & $-4,20$ & 51 & 0,000104 \\
\hline
\end{tabular}


TABELA 20 - Resultados do teste $t$ independente, entre os grupos de oclusão normal e de Classe II, subdivisão com assimetria facial aparente. Radiografia Submentoniana - Medidas Angulares

\begin{tabular}{|c|c|c|c|c|c|c|c|}
\hline Variáveis & $\begin{array}{l}\text { Média } \\
\text { Oclusão } \\
\text { Normal }\end{array}$ & $\begin{array}{l}\text { D.P. } \\
\text { Oclusão } \\
\text { Normal }\end{array}$ & $\begin{array}{c}\text { Média } \\
\text { Classe II, } \\
\text { subdivisão }\end{array}$ & $\begin{array}{c}\text { D.P. } \\
\text { Classe II, } \\
\text { subdivisão }\end{array}$ & $\begin{array}{c}\text { Valor } \\
t\end{array}$ & gl & $p$ \\
\hline EIE-EIC & 0,81 & 0,64 & 0,72 & 0,42 & 0,56 & 51 & 0,572459 \\
\hline ETE-ETC & & & & 0,40 & 0,71 & 51 & 0,475002 \\
\hline ETPTM-ETC & 1 , & 0,84 & 1,28 & 1,21 & $-0,18$ & 51 & 0,853400 \\
\hline ETPTM-ETE & 1,46 & 1,02 & 1,27 & 1,14 & 0,62 & 51 & 0,537630 \\
\hline ETMI-ETE & & & & 1,32 & $-6,75$ & 51 & 0,000000 \\
\hline ETMI-ETC & 1,02 & 0,67 & 2,94 & 1,35 & $-6,73$ & 51 & 0,000000 \\
\hline ETMI-ETPTM & & 1,04 & 3,30 & 1,97 & $-4,56$ & 51 & 0,000031 \\
\hline ETMS-ETE & 1,04 & 0,92 & 1,41 & 1,11 & $-1,31$ & 51 & 0,196007 \\
\hline ETMS-ETC & 1,00 & 0,76 & 1,45 & 1,07 & $-1,79$ & 51 & 0,078526 \\
\hline ETMS-ETPTM & 1,27 & 0,97 & 1,18 & 0,99 & 0,32 & 51 & 0,743785 \\
\hline
\end{tabular}

TABELA 21 - Resultados do teste $t$ independente, entre os grupos de oclusão normal e de Classe II, subdivisão com assimetria facial aparente. Radiografia Submentoniana - Variáveis Adicionais

\begin{tabular}{|l|c|c|c|c|c|c|c|}
\hline Variáveis & $\begin{array}{c}\text { Média } \\
\text { Oclusão } \\
\text { Normal }\end{array}$ & $\begin{array}{c}\text { D.P. } \\
\text { Oclusão } \\
\text { Normal }\end{array}$ & $\begin{array}{c}\text { Média } \\
\text { Classe II, } \\
\text { subdivisão }\end{array}$ & $\begin{array}{c}\text { D.P. } \\
\text { Classe II, } \\
\text { subdivisão }\end{array}$ & $\begin{array}{c}\text { Valor } \\
\mathbf{t}\end{array}$ & $\mathbf{g l}$ & $\mathbf{P}$ \\
\hline PCM-LMM & 1,77 & 1,53 & 3,48 & 3,43 & $-2,43$ & 51 & 0,018320 \\
\hline PCM-CMM & 2,25 & 1,49 & 2,30 & 2,65 & $-0,08$ & 51 & 0,935579 \\
\hline POSM & 1,46 & 1,07 & 1,36 & 1,04 & 0,33 & 51 & 0,742121 \\
\hline POSMS & 1,69 & 1,16 & 1,90 & 1,56 & $-0,56$ & 51 & 0,573738 \\
\hline
\end{tabular}


TABELA 22 - Resultados do teste $t$ independente, entre os grupos de oclusão normal e de Classe II, subdivisão com assimetria facial aparente. Radiografia Póstero-Anterior

\begin{tabular}{|l|l|l|l|l|c|c|c|}
\hline Variáveis & $\begin{array}{c}\text { Média } \\
\text { Oclusão } \\
\text { Normal }\end{array}$ & $\begin{array}{c}\text { D.P. } \\
\text { Oclusão } \\
\text { Normal }\end{array}$ & $\begin{array}{c}\text { Média } \\
\text { Classe II, } \\
\text { subdivisão }\end{array}$ & $\begin{array}{c}\text { D.P. } \\
\text { Classe II, } \\
\text { subdivisão }\end{array}$ & $\begin{array}{c}\text { Valor } \\
\mathbf{t}\end{array}$ & $\mathbf{g l}$ & $\mathbf{p}$ \\
\hline APLANOZ & 89,90 & 1,27 & 89,59 & 1,70 & 0,92 & 51 & 0,357079 \\
\hline APLOCLUSAL & 89,34 & 1,74 & 89,59 & 2,00 & $-0,48$ & 51 & 0,626886 \\
\hline APLANTEG & 88,63 & 1,51 & 88,19 & 2,88 & 0,71 & 51 & 0,477104 \\
\hline DESVENA & 1,33 & 0,84 & 1,52 & 1,59 & $-0,57$ & 51 & 0,565684 \\
\hline DESMAND & 2,71 & 1,63 & 2,88 & 1,80 & $-0,36$ & 51 & 0,717722 \\
\hline A1 & 1,40 & 0,90 & 1,71 & 1,58 & $-0,88$ & 51 & 0,378793 \\
\hline B1 & 1,58 & 0,97 & 2,27 & 1,25 & $-2,26$ & 51 & 0,027927 \\
\hline ÂANT & 2,40 & 1,51 & 4,13 & 2,66 & $-2,98$ & 51 & 0,004407 \\
\hline DISTZ & 1,77 & 1,24 & 1,71 & 1,63 & 0,14 & 51 & 0,886098 \\
\hline DISTCO & 3,20 & 2,42 & 3,14 & 2,63 & 0,08 & 51 & 0,931957 \\
\hline DISTZA & 2,86 & 1,96 & 3,30 & 2,81 & $-0,66$ & 51 & 0,506648 \\
\hline DISTNC & 2,51 & 1,57 & 2,33 & 2,48 & 0,32 & 51 & 0,746546 \\
\hline DISTJ & 2,47 & 1,65 & 2,68 & 2,56 & $-0,36$ & 51 & 0,719494 \\
\hline DISTAG & 4,25 & 3,19 & 3,67 & 3,01 & 0,66 & 51 & 0,508213 \\
\hline ALTA6 & 1,37 & 1,05 & 1,57 & 1,33 & $-0,60$ & 51 & 0,549668 \\
\hline C0-AG & 2,70 & 2,10 & 3,35 & 3,06 & $-0,91$ & 51 & 0,365306 \\
\hline CO-ME & 2,26 & 2,21 & 2,45 & 2,26 & $-0,31$ & 51 & 0,757526 \\
\hline ME-AG & 2,28 & 1,92 & 3,45 & 2,59 & $-1,88$ & 51 & 0,065047 \\
\hline
\end{tabular}




\section{Discussão}




\section{DISCUSSÃO}

\subsection{AMOSTRA}

$\mathrm{Na}$ coleta da amostra foram selecionados somente os casos onde as características dentárias eram bem definidas. No grupo de má oclusão de Classe II, subdivisão, foram incluídos apenas os casos que apresentavam a relação molar de Classe I de um lado e de Classe II completa do outro. Os casos que apresentavam $1 / 2$ ou $3 / 4$ de Classe II foram excluídos, pois poderiam atenuar as reais características da Classe II, subdivisão ${ }^{55}$. No grupo com oclusão normal, os casos não poderiam ter sofrido tratamento ortodôntico prévio, pois, deste modo, não haveria uma relação natural dos dentes com suas bases apicais ${ }^{6,55,107}$.

Outro critério adotado para a seleção da amostra, para ambos os grupos, foi a presença de todos os dentes permanentes superiores e inferiores, em ambos os arcos dentários, até os primeiros molares permanentes ${ }^{1,6,26,55,68,107,117}$. Desse modo, eliminaram-se possíveis deslocamentos dentários que ocasionariam alterações no relacionamento dos dentes e influenciariam o aparecimento de assimetrias dentárias ${ }^{55}$. Este critério foi adotado, pois como já foi demonstrado na literatura, mutilações nos arcos dentários e ausência de dentes, durante o desenvolvimento mandibular, podem provocar uma assimetria esquelética ${ }^{10,108}$ e uma remodelação condilar ${ }^{78}$.

A ausência de deslocamento mandibular lateral durante 0 fechamento bucal, detectado durante o exame clínico ${ }^{1,6,26,55,107,114,117}$, outro critério utilizado para a seleção da amostra, foi baseado em trabalhos da literatura $^{120,124,139}$, onde os autores afirmavam que a presença de um deslocamento mandibular lateral devido a um contato prematuro, causa uma alteração da relação ântero-posterior do lado contrário ao desvio, ocasionando um falso diagnóstico da oclusão daquele lado.

Outro pré-requisito adotado, foi a ausência de trauma facial ou condições médicas que poderiam ter alterado o crescimento das bases apicais $^{6,26,55,100,107}$, pois as respostas compensatórias a uma injúria podem induzir um desequilíbrio no crescimento do côndilo e do ramo como um todo ${ }^{30} \mathrm{e}$ 
já foi constatado a existência de uma associação entre o trauma e o crescimento assimétrico da mandíbula ${ }^{65,100,119,123,129}$.

O apinhamento, nos indivíduos com má oclusão de Classe II, subdivisão, quando presente, deveria ser de no máximo $3 \mathrm{~mm}$ nos arcos dentários superior e/ou inferior, desde que simétrico, pois assim não ocasionaria assimetrias dentoalveolares devido a problemas de falta de espaço em um quadrante ${ }^{26,55}$. Tolerou-se a presença deste pequeno apinhamento, pois é muito difícil de encontrarmos casos de más oclusões sem nenhum apinhamento ${ }^{1,6,55}$.

A ligeira diferença quanto ao gênero nos dois grupos estudados não apresenta evidências de se constituir em um problema, visto que os autores ARNOLD, ANDERSON e LILYEMARK ${ }^{8}$, ao estabelecerem padrões de normalidade nas radiografias submentonianas, não verificaram diferenças estatisticamente significantes, entre os gêneros masculino e feminino, quanto às assimetrias. MELNIK ${ }^{74}$, ao avaliar as assimetrias por meio de radiografias oblíquas a $45^{\circ}$ em pacientes de ambos os gêneros, com mais de 14 anos, observou que não há diferença estatisticamente significante entre os gêneros. Os autores PONYI, SZABÓ e NYILAS ${ }^{99}$ também não encontraram diferença estatisticamente significante entre os gêneros. $O$ estudo sobre a assimetria craniofacial em cefalogramas póstero-anteriores, realizado por CHEBIB e $\mathrm{CHAMMA}^{23}$, e sobre a prevalência da assimetria dentária e facial em escolares americanos de ambos os gêneros, realizado por SHEATS et al.. ${ }^{118}$, não constatou uma associação entre o gênero e a assimetria.

Com relação às idades médias entre os grupos estudados, verificourse que os grupos de Classe II, subdivisão e o de oclusão normal apresentavam idades médias de 15,21 e 22,42 anos, respectivamente. Para o gênero feminino esta diferença foi considerada desprezível, uma vez que nesta idade a maior parte da maturação já ocorreu. Quanto ao masculino, ainda há uma quantidade razoável de crescimento. Contudo, MELNIK ${ }^{74}$, estudando a assimetria mandibular, observou que existe uma probabilidade semelhante de ocorrer uma acentuação ou diminuição desta assimetria com o crescimento, podendo-se, dentro de certos limites, fazer uma analogia em relação ao crescimento craniofacial, de uma forma geral. Assim, considerando a maturação quase completa do gênero masculino e a igual probabilidade de 
melhora da assimetria mandibular, com o crescimento, essa diferença de idade entre os grupos não interferiu na avaliação.

\subsection{METODOLOGIA}

As fotografias frontais foram obtidas com o paciente sentado na posição ereta, olhando para frente na linha do horizonte ${ }^{34}$, com o Plano de Frankfurt paralelo ao solo, oclusão habitual e postura labial relaxada, a fim de que os dados fossem coletados adequadamente ${ }^{7,16,17,126}$. Alguns autores $34,81,133$ utilizam a posição natural da cabeça, pois afirmam que é a que o paciente conduz no seu dia-a-dia. Contudo trabalhos na literatura comprovam que pacientes apresentando uma assimetria facial tendem a compensar esta assimetria alterando a postura da cabeça ${ }^{124}$, o que mascara a real posição da cabeça e dificulta uma avaliação facial precisa deste indivíduo. Outros autores $^{28,137}$ utilizam o plano interpupilar paralelo ao solo, afirmando que este plano, paralelo ao plano de Frankfurt, é consistente e prático. Tomando as fotografias com o plano de Frankfurt paralelo ao solo, pode-se posicionar a cabeça do paciente corretamente, sem giros ou inclinações, tornando a análise fotográfica mais precisa.

As radiografias submentonianas e póstero-anteriores foram tomadas com o paciente em máxima intercuspidação habitual, como preconizado pelos autores SHAH e JOSHI ${ }^{17}$, MONGINI e SCHMID ${ }^{79}$, SCHMID, MONGINI e FELÍSIO ${ }^{114}$, O’BYRN et al.. ${ }^{86}$ e LAM, SADOWSKY e OMERZA $^{64}$. Contudo, outros autores ${ }^{37,106,138,140,141}$ recomendam sua obtenção em relação cêntrica quando se deseja detectar qualquer desvio mandibular funcional que possa interferir na avaliação da assimetria mandibular, em relação à maxila e à base do crânio. Isto se aplica, principalmente, aos casos de Classe II, uma vez que já se demonstrou que estes geralmente apresentam um maior desvio, para anterior, do que aqueles com Classe $1^{101,135}$. Entretanto, neste trabalho, um dos critérios adotados para a seleção da amostra, foi a ausência de desvio funcional mandibular lateral durante 0 fechamento bucal $^{1,6,26,55,107,114,117}$, o que assegurou uma precisão na correta avaliação da assimetria mandibular, em relação à maxila e à base do crânio. Para a 
avaliação dos desvios funcionais mandibulares, foi realizada a manipulação bilateral da mandíbula em relação cêntrica. Considerou-se este tipo de manipulação suficiente para levar os côndilos em relação cêntrica, desde que os pacientes não apresentassem nenhum sintoma de distúrbios temporomandibulares ${ }^{109}$.

Como já mencionado, no capítulo sobre Materiais e Métodos, foram utilizados valores absolutos, para eliminar a possibilidade de que valores de diferença, positivos ou negativos, se anulem no cálculo das médias para cada grupo ${ }^{8}$. Este procedimento foi adotado, também, pois pacientes que apresentam ausência de assimetria facial ou dentária aparente, demonstram diferenças esqueléticas de tamanho entre os lados direito e esquerdo da maxila e da mandíbula ${ }^{117,134}$. MELNIK ${ }^{74}$ demonstrou que a mandíbula apresenta-se assimétrica em jovens em crescimento, em diferentes idades. Além disso, como já foi comprovado ${ }^{70}$, indivíduos com oclusão normal também apresentam um certo grau de assimetria do arco dentário. Outros estudos ${ }^{23,91,94,95,99,134,142}$ sobre assimetria direcional, observaram desvios dentários ou esqueléticos, predominantemente para um dos lados. Portanto, se os valores reais fossem utilizados, os grupos poderiam apresentar uma assimetria direcional que influiria nos resultados obtidos, levando a conclusões distorcidas ${ }^{55}$.

\subsection{MENSURAÇÃO DAS GRANDEZAS CEFALOMÉTRICAS}

A mensuração das grandezas cefalométricas foi realizada com o auxílio de um computador, pois este possibilita a manipulação de um maior número de dados em um menor período de tempo. O programa Dentofacial Planner 7.0, disponível na Disciplina de Ortodontia, proporcionou a medição com a precisão de $0,1 \mathrm{~mm}$ ou 0,1 grau, tendo sido utilizado em diversos trabalhos anteriores ${ }^{26,55,56,87,98}$, assegurando uma maior fidedignidade. Este programa permite, também, a exportação dos resultados obtidos para um programa de estatística, garantindo uma maior precisão na transferência de dados de um programa para o outro. Visto que, a digitação dos valores obtidos e anotados manualmente, no método convencional, para o programa de 
estatística, é lento e apresenta o potencial de aumentar os erros durante a manipulação dos dados $55,57,87,98$.

O número de variáveis utilizadas nesta pesquisa foi relativamente grande, sendo um total de 156 variáveis, onde eram 39 ímpares e 40 pares, que representam 80 variáveis referentes aos lados direito e esquerdo de cada indivíduo, sendo utilizadas somente as diferenças e proporções entre as mesmas. Desta forma, no sumário dos resultados nas tabelas analisadas, somente 76 variáveis podem ser vistas. Portanto, a utilização do método computadorizado facilitou o trabalho, além de diminuir a possibilidade de erros na fase de mensuração das medidas cefalométrica ${ }^{104}$.

\subsection{PRECISÃO DA METODOLOGIA}

Para avaliar os erros da metodologia, HOUSTON ${ }^{51}$ recomenda, idealmente, que os traçados e medições sejam realizadas duas vezes. Contudo, caso isto não seja possível, aconselha que as radiografias sejam selecionadas ao acaso, da amostra total. Neste estudo, foram traçados e medidos novamente dez indivíduos, escolhidos aleatoriamente, totalizando 10 radiografias submentonianas, 10 póstero-anteriores e 10 fotografias frontais, para o cálculo dos erros casuais e sistemáticos.

Os erros casuais (DAHLBERG ${ }^{27}$ ) das medidas das fotografias demonstraram, pela tabela 3 , que os maiores valores foram referentes às variáveis das medidas de proporção. Talvez a maior magnitude desses erros tenha ocorrido por estas variáveis apresentarem os valores dos denominadores menores na segunda medida do que na primeira. Contudo, como esses valores estão em porcentagem, e sendo esta porcentagem pequena, em torno de 1\%, estes erros não afetaram a precisão das medidas realizadas. Em se tratando dos erros casuais para as medidas das radiografias, verificou-se pelas tabelas de 4 a 10 que os maiores valores foram referentes às variáveis do sistema de coordenadas mandibulares, na radiografia submentoniana. Os erros casuais advêm das dificuldades na identificação dos pontos cefalométricos e também devido à imprecisão nas definições de certos pontos ${ }^{51}$. A maior magnitude desses erros pode ser justificada pelo fato dos pontos na região condilar serem 
de difícil visualização nessa radiografia. Como as diversas medidas, neste sistema de coordenadas, são realizadas em relação aos eixos originários destes pontos, elas são afetadas pela imprecisão em suas localizações. Embora os erros casuais, nestes casos, tenham sido de magnitude moderada, eles não afetaram muito a precisão das medidas realizadas, pois podem ocorrer de modo a subestimar ou superestimar os valores reais. Dessa forma, desde que haja um equilíbrio entre os valores subestimados e superestimados, as médias serão pouco afetadas ${ }^{112}$, como demonstrado pela ausência de significância estatística na avaliação do erro sistemático dessas variáveis. $\mathrm{Na}$ radiografia póstero-anterior, 10 variáveis mostraram valores de magnitude acima de $1 \mathrm{~mm}$, entretanto estes erros não afetaram a precisão das medidas realizadas. Desde que haja um equilíbrio entre os valores subestimados e os superestimados, as médias obtidas no erro sistemático não são afetadas, conforme pode ser verificado pela ausência estatística na avaliação destas variáveis pelo teste t pareado $26,55,112$.

Os resultados da avaliação dos erros sistemáticos demonstraram que houve uma diferença estatisticamente significante entre a primeira e a segunda medição somente para uma variável na fotografia frontal e para duas variáveis para a radiografia submentoniana, e todas ao nível de $p<0,05$. Os erros sistemáticos se manifestam quando um determinado parâmetro é persistentemente sub ou superestimado, podendo ocorrer quando um pesquisador modifica a sua técnica de mensuração após um certo tempo, ou então quando ele tende subconscientemente a direcionar os resultados de acordo com as suas expectativas em relação às conclusões do estudo ${ }^{51,112}$. Percebe-se que as variáveis que demonstraram diferenças entre os pares dos traçados repetidos consistiram de estruturas de difícil visualização e padronização. Desta forma, para a fotografia frontal, a única variável que apresentou diferença estatisticamente significante foi a distância do gônio esquerdo ao mento (GoE-Me - TABELA 3), onde a localização do mento é de difícil visualização. As variáveis que apresentaram diferenças estatisticamente significantes, na radiografia submentoniana, pertencem ao sistema de coordenadas zigomaticomaxilares, sendo o ponto na distal do molar inferior e a linha média mandibular ao eixo interpterigomaxilar (PDMI-EIPTM, LMM-EIPTM - TABELA 6). A justificativa para estas diferenças deveurse aos pontos que 
originam o eixo interpterigomaxilar uma vez que as estruturas mais mediais e posteriores de cada fissura pterigomaxilar apresentam visualização reduzida ${ }^{55}$.

\subsection{INTERPRETAÇÃO DOS RESULTADOS OBTIDOS NA CORRELAÇÃO DA FOTOGRAFIA FRONTAL COM AS RADIOGRAFIAS SUBMENTONIANA E PÓSTERO-ANTERIOR}

A avaliação do tamanho das estruturas na radiografia submentoniana, assim como nas fotografias frontais, pode ser questionada. Contudo, embora GILBERT ${ }^{41}$, tenha relatado erros significantes em medidas ântero-posteriores e precisão nas medidas transversais, a avaliação da assimetria ântero-posterior, como utilizada neste estudo, não é afetada, pois o que se está avaliando são as diferenças entre os dois lados, que sofrerão a mesma distorção.

Para o teste de correlação foram eliminadas todas as medidas dentárias, uma vez que o objetivo do trabalho era avaliar a assimetria esquelética. Como as medidas das linhas médias dentárias inferior e superior (LMDI e LMDS - TABELAS 11, 12 e 13; B1 e A1 - TABELA 15), são medidas frontais e refletem a posição ântero-posterior dos dentes, estas foram utilizadas para avaliação de uma possível correlação destas com as medidas das fotografias frontais.

O sinal do r, no teste de correlação de Pearson, não indicou uma correlação inversa entre as medidas avaliadas, mas sim um aumento da assimetria presente entre as medidas das fotografias frontais e as medidas das radiografias. Pois, na proporção, quando o lado maior está sobre o menor, o valor desta proporção daria maior que $100 \%$ e quando o lado menor está sobre o maior o valor desta proporção seria menor que $100 \%$, contudo, não nos interessa qual o lado maior, mas sim que, quanto mais diferente de 10 valor da proporção, tanto para mais ou para menos, maior a assimetria entre as medidas da fotografia frontal e da radiografia submentoniana.

As assimetrias esqueléticas que existem e são detectáveis radiograficamente, de uma forma geral, apresentam uma correlação muito 
pequena com as assimetrias observadas na fotografia (TABELAS 11 a 15). $O$ que já era esperado, pois como o grau de assimetria é muito pequeno, esperava-se uma correlação pequena quando comparado com a oclusão normal como em outros estudos ${ }^{1,55,56,107}$. Além do que o tecido mole tende a minimizar a assimetria esquelética presente ${ }^{117}$.

A assimetria facial nos indivíduos com oclusão normal não foi avaliada, especula-se que se fosse realizada uma avaliação fotográfica destes indivíduos e comparada com a avaliação dos indivíduos de Classe II, subdivisão provavelmente daria um comportamento semelhante ao obtido nos estudos anteriores $^{1,55,56}$, onde foi comprovado que a Classe II, subdivisão não apresenta assimetrias esqueléticas em relação à oclusão normal.

Poucas medidas, entre a fotografia frontal e a radiografia submentoniana, apresentaram uma correlação significante, sendo que as medidas que apresentaram uma maior correlação foram as que representam a linha média mandibular (TABELAS 11 e 14) e as linhas médias dentárias inferior e superior (TABELAS 11 e 13), contudo, estas correlações não foram constantes em todos os grupos, o que demonstra que a assimetria é muito suave e que o tecido mole está refletindo uma pequena assimetria esquelética encontrada na radiografia. Os desvios das linhas médias dentárias refletem o posicionamento assimétrico dos molares, demonstrando, mais uma vez, o componente dentário da má oclusão de Classe II, subdivisão e uma participação muito pequena do componente esquelético. No grupo 3, pode-se observar uma correlação moderada entre a variável fotográfica que mede a assimetria mandibular (ZyDMe/ZyEMe) e a variável radiográfica que mede o desvio da linha média mandibular (LMM-EIC; PCM-LMM) (TABELAS 11 a 14), e entre a medida fotográfica que representa o desvio da mento (Me) e a medida PCM-LMM (TABELA 14). Por meio destes resultados podemos observar a presença da assimetria esquelética mandibular e o tecido mole refletindo esta pequena assimetria esquelética. $O$ que não significa que os dentes inferiores estejam acompanhando esta assimetria mandibular, uma vez que neste grupo a linha média dentária inferior está coincidente com a linha média da face e a superior é que se encontra desviada.

Também, podemos observar para o grupo 3, uma correlação significante entre o desvio da linha média dentária superior (LMDS-EIC; LMDS- 
EIPTM) e as variáveis que medem a assimetria mandibular nas fotografias (ZyDMe/ZyEMe; GoDMe/GoEMe; ZyDGoD/ZyEGoE) (TABELAS 11 e 13). Uma vez que o desvio da linha média reflete a posição assimétrica dos molares, este resultado confirma a maior participação do molar superior como causa da subdivisão para este grupo, reafirmando o que já foi amplamente discutido em estudos anteriores, que a Classe II, subdivisão é principalmente dentária ${ }^{1,55,107}$ com uma pequena participação esquelética.

$\mathrm{Na}$ radiografia póstero-anterior, observa-se uma correlação significante entre o desvio da espinha nasal anterior (DESVENA) e quase todas as medidas da fotografia que avaliam a assimetria mandibular (ZyDMe/ZyEMe; GoDMe/GoEMe; ZyDGoD/ZyEGoE) e para, praticamente, todos os grupos, demonstrando a assimetria da mandíbula refletindo um desvio da espinha nasal anterior (ENA). O desvio da ENA no grupo 3 reflete a maior participação das estruturas da maxila neste grupo. Como já mencionado anteriomente, este resultado já era esperado, visto que neste grupo a Classe II, subdivisão é ocasionada principalmente por um posicionamento mais mesial do molar superior no lado da Classe II. A correlação significante do subnasal (Sbn), na fotografia, com o desvio da espinha nasal anterior (DESVENA), na radiografia, demonstra um posicionamento assimétrico da maxila, o que não significa que os dentes estejam posicionados assimetricamente.

\subsection{AVALIAÇÃO DAS ASSIMETRIAS ENTRE OS GRUPOS DE CLASSE II, SUBDIVISÃO COM ASSIMETRIA FACIAL APARENTE E DE OCLUSÃO NORMAL}

Como em outras pesquisas ${ }^{26,55,107}$, neste estudo, também, foi utilizada a análise de RITUCCI e BURSTONE ${ }^{37,106}$, para avaliar a assimetria das estruturas dentoesqueléticas em relação aos sistemas de coordenadas da mandíbula, do assoalho craniano, do complexo zigomático maxilar, e mais as variáveis adicionais, correlacionando com as medidas obtidas na fotografia frontal. Complementando esta avaliação foram incorporadas a análise das assimetrias em relação às coordenadas dentárias e as avaliações angulares entre as abscissas dos três sistemas de coordenadas da análise de RITUCCI e 
BURSTONE ${ }^{37,106}$, de acordo com ROSE et al.. ${ }^{107}$, acrescidas ainda das abscissas dentárias em relação às outras abscissas mencionadas. Assim, objetivourse conseguir um maior número possível de informações em relação às características do grupo de Classe II, subdivisão, para correlacionar com as medidas da fotografia frontal e para comparação com o grupo de oclusão normal. Esta análise ${ }^{37,106}$ utiliza os forames espinhosos para estabelecer o eixo sagital de simetria da base do crânio, que, de acordo com MARMARY, ZILBERMAN e MIRSKY ${ }^{72}$ se constituem em estruturas de grande estabilidade, fácil localização e boa reprodutibilidade. Evidentemente, nenhum ponto cefalométrico é imutável, mas estes são os que apresentam maior estabilidade e fácil localização.

\subsubsection{SISTEMA DE COORDENADAS MANDIBULARES}

$O$ teste $\mathrm{t}$ para variáveis não dependentes, referente aos resultados entre o grupo de oclusão normal e o grupo com Classe II, subdivisão, demonstrou uma diferença estatisticamente significante para a variável PDMI-ETC, na tabela $16(p<0,05)$, referente à posição ântero-posterior do primeiro molar inferior, em relação à posição do eixo transcondilar. Este resultado demonstra que são os primeiros molares inferiores, do lado da Classe II, que na maioria dos casos, estão mais posicionados para distal, comprovando que o principal componente da Classe II, subdivisão é dentoalveolar. ALAVI, BEGOLE, SCHNEIDER ${ }^{1}$; ROSE et al. ${ }^{107}$ e JANSON ${ }^{55}$ encontraram o posicionamento distal dos molares inferiores como o principal responsável pela produção da Classe II, de um dos lados e uma menor participação dos molares superiores ${ }^{1,55}$. No presente estudo não foi encontrada nenhuma diferença estatisticamente significante para as medidas dos molares superiores (TABELA 16), contrariando os resultados de ALAVI, BEGOLE, SCHNEIDER ${ }^{1}$ e JANSON ${ }^{55}$, tendo somente como principal componente da Classe II, subdivisão o posicionamento mais distal do molar inferior no lado da Classe II. 


\subsubsection{SISTEMA DE COORDENADAS DO ASSOALHO CRANIANO}

Neste sistema de coordenadas, para a medição das diversas estruturas dentárias e esqueléticas, adotaram-se como parâmetro os forames espinhosos, baseando-se nos trabalhos de MOSS, SALENTIJN ${ }^{82}$ que demonstraram que a passagem e a localização dos feixes neuromusculares, durante o crescimento, não podem ser violadas. Várias outras pesquisas seguiram esta linha de pensamento, como o de MARMARY, ZILBERMAN, MIRSKY ${ }^{72}$ que utilizaram a bissetriz perpendicular de uma linha unindo os dois forames espinhosos com a linha média oraniana. Estes estudos, juntamente com os publicados por FORSBERG, BURSTONE, HANLEY ${ }^{37}$ e JANSON ${ }^{55}$, contribuíram na adoção do plano sagital mediano, da base craniana, neste trabalho.

Os resultados, neste sistema de coordenadas (TABELA 17), no sentido ântero-posterior, somente a variável PDMI-ETE foi estatisticamente significante, demonstando novamente, que o principal fator da subdivisão é o posicionamento mais distal do primeiro molar inferior no lado da Classe II. Corroborando com o que foi demonstrado anteriormente, que o principal componente da Classe II, subdivisão é dentoalveolar. Este resultado difere do encontrado por JANSON ${ }^{55}$ que além da variável PDMI-ETE, encontrou também uma diferença estatisticamente significante para as variáveis PCM-EIE, GOEIE e LMM-EIE, no sentido transversal, o que demonstra certa tendência para uma assimetria esquelética lateral do posicionamento espacial da mandíbula, em relação ao assoalho craniano, no grupo com Classe II, subdivisão. Contudo, no presente estudo para este sistema de coordenadas, não foram encontradas diferenças significantes para as variáveis esqueléticas, sustentando as evidências do fator principal da subdivisão ser dentoalveolar.

\subsubsection{SISTEMA DE COORDENADAS ZIGOMATICOMAXILARES}

Os resultados para este sistema de coordenadas, demonstraram uma diferença estatisticamente significante somente para a variável PDML ETPTM (TABELA 18), o que demonstra novamente que o componente principal 
da subdivisão, é o posicionamento mais distal do primeiro molar inferior no lado da Classe II. As variáveis analisadas neste sistema de coordenadas são na maioria esqueléticas, como para as demais variáveis deste grupo não foi encontrada nenhuma diferença estatisticamente significante, este resultado demonstrou a pequena participação das estruturas esqueléticas na diferenciação entre os grupos estudados. Comprovando, uma vez mais, que o principal fator da Classe II, subdivisão é dentoalveolar. Resultado este, que corrobora com os achados por JANSON ${ }^{55}$ Contudo podemos observar, na tabela 18, que os valores apresentados para as variáveis que representam a linha média mandibular e a linha média dentária inferior, apesar de não apresentarem uma diferença estatisticamente significante entre os grupos, apresentaram valores maiores no grupo com Classe II, subdivisão com assimetria facial aparente, em relação ao grupo com oclusão normal, demonstrando uma tendência dos indivíduos com Classe II, subdivisão e assimetria facial aparente apresentarem um desvio maior do que o grupo com oclusão normal em relação ao eixo interpterigomaxilar ${ }^{55}$. A ausência de uma diferença significante do posicionamento da linha média superior entre os dois grupos sugere um posicionamento mais simétrico dos dentes superiores em relação à maxila ${ }^{8,55}$.

\subsubsection{SISTEMA DE COORDENADAS DENTÁRIAS}

Quando realizado o teste t, entre o grupo de oclusão normal e o grupo com Classe II, subdivisão apresentando assimetria facial aparente, observourse uma diferença estatisticamente significante para todas as variáveis estudadas (TABELA 19), tanto para o eixo intermolares superiores como inferiores, demonstrando, novamente, que o principal componente da má oclusão estudada é dentoalveolar ${ }^{55}$. Os desvios das linhas médias dentárias, inferior ou superior, em relação ao eixo intermolares do arco oposto (LMDSEIMI, LMDIEIMS), são resultados que poderiam ser previstos, uma vez que os casos selecionados eram de subdivisão e apresentavam apenas um mínimo de apinhamento simétrico. Entretanto, observou-se também um desvio das linhas médias dentárias em relação aos eixos intermolares de seu próprio arco 
dentário (LMDFEIMI, LMDS-EIMS). Como houve desvios estatisticamente significantes para as duas linhas médias, isto sugere uma assimetria das formas dos arcos superior e inferior na Classe II, subdivisão. Demonstrando que mesmo os indivíduos com assimetria facial aparente apresentam os arcos dentários assimétricos. Estudos anteriores ${ }^{55,56}$ também observaram que os arcos dentários na Classe II, subdivisão são assimétricos. O desvio da linha média mandibular, em relação ao eixo intermolares inferiores (LMM-EIMI), sugere, novamente, uma disposição assimétrica dos dentes inferiores em sua base óssea. A linha média mandibular inferior, também, apresentou um maior desvio em relação ao eixo intermolares superiores (LMM-EIMS), no grupo com subdivisão, do que no grupo com oclusão normal. Estes resultados, semelhantes aos encontrados por JANSON $^{55}$, sugerem um deslocamento dos dentes superiores para um dos lados, um desvio dentoalveolar e/ou esquelético mandibular para o lado oposto, ou, ainda, uma combinação desses fatores, nos casos de Classe II, subdivisão.

\subsubsection{MEDIDAS ANGULARES}

Os ângulos entre os eixos condilar, dos forames espinhosos e transpterigomaxilar (EIE-EIC, ETE-ETC, ETPTM-ETC, ETPTM-ETE) não mostraram diferenças estatisticamente significantes entre os dois grupos, demonstrando que, mesmo œm assimetria facial aparente não há assimetria posicional da mandíbula e conseqüentemente assimetria do crânio(TABELA 20). Isto significa, que na Classe II, subdivisão não ocorre a mesma rotação mandibular, em relação à base do crânio, encontrada nos casos com mordida cruzada unilateral, com desvio de $2 \mathrm{~mm}$ da linha média inferior para o lado da mordida cruzada, em casos sem apinhamento e sem desvio mandibular funcional, como encontrado por O'BYRN et al. ${ }^{86}$. Observourse, ainda, uma diferença estatisticamente significante para todas as variáveis do eixo transmolares inferiores (ETMI-ETE, ETMI-ETC e ETMI-ETPTM), representadas na tabela $20 \quad(p<0,05)$, demonstrando a grande participação de um posicionamento assimétrico dos dentes inferiores, em relação ao crânio, à sua base apical e à maxila, para produzir a subdivisão, como foi demonstrado por 
trabalhos anteriores ${ }^{1,55,107}$. Rose et al. ${ }^{107}$ também encontraram resultados semelhantes entre o eixo transmolares inferiores e os eixos transcondilar e transespinhosos (ETMI-ETC, ETMI-ETE). Não foram encontradas diferenças estatisticamente significantes, entre os grupos estudados, quanto aos ângulos formados pelo eixo transmolares superiores e os eixos transespinhosos, transcondilar e transpterigomaxilar (ETMS-ETE, ETMS-ETC e ETMS-ETPTM). Demonstrando que para o grupo com Classe II, subdivisão e assimetria facial aparente os molares superiores estão simetricamente dispostos em relação à base do crânio, ao eixo transcondilar e à maxila. Contrariando o resultado encontrado por JANSON ${ }^{55}$, que observou uma diferença estatisticamente significante para a variável ETMS-ETC, demonstrando que no grupo com Classe II subdivisão, incluindo pacientes com e sem assimetria facial aparente, os molares superiores apresentam uma pequena rotação entre o eixo transmolares superiores e o eixo transcondilar. Possivelmente, esta diferença entre os resultados deste trabaho e os encontrados por JANSON ${ }^{55}$ tenha ocorrido devido ao número reduzido de pacientes com Classe II, subdivisão e com assimetria facial aparente pertencentes ao tipo 2, sendo somente $17,39 \%$ da amostra, o que representa quatro pacientes.

Embora ALAVI, BEGOLE e SCHNEIDER ${ }^{1}$ tenham evidenciado, em seu trabalho, que o posicionamento ântero-posterior dos molares inferiores se constituía na variável com o maior poder discriminatório entre os grupos de má oclusão de Classe II, subdivisão e o de oclusão normal, sua metodologia não Ihes permitiu evidenciar se isto se devia a um posicionamento mais para posterior do molar inferior, dentro de sua base, ao posicionamento da base no complexo craniofacial, a uma assimetria mandibular, ou ainda a uma combinação da três situações. No presente trabalho, como não houve diferença entre o ângulo formado pelos eixos transcondilar, transforame espinhoso e transpterigomaxilar, ficou demonstrada a ausência de um posicionamento assimétrico da mandíbula em relação ao complexo craniofacial, mesmo nos indivíduos com Classe II, subdivisão e que apresentavam uma assimetria facial aparente, estes resultados suportam um posicionamento mais para distal dos primeiros molares inferiores na mandíbula, na constituição da subdivisão, que foi evidenciado pelas variáveis PDMI-ETC, PDMI-ETE e PDMI-ETPTM (TABELAS 16, 17 e 18, respectivamente). Como 
não foram incluídos indivíduos que apresentavam deslocamento mandibular lateral, a diferença no posicionamento ântero-posterior dos molares inferiores também não pode ser atribuída a esse fator. Estes resultados demonstram novamente, que o principal fator responsável pela Classe II, subdivisão é dentoalveolar, mesmo nos indivíduos que apresentam este tipo de má-oclusão e que possuem também uma assimetria facial aparente. Sendo esta subdivisão causada principalmente por um posicionamento mais distalizado do molar inferior no lado da Classe II.

\subsubsection{VARIÁVEIS ADICIONAIS}

No teste $t$ independente foi encontrada uma diferença estatisticamente significante somente para a variável adicional esquelética PCM-LMM (TABELA 21), demonstrando um pouco de assimetria esquelética do tamanho dos lados da mandíbula maior na Classe II, subdivisão, que talvez justifique a aparência assimétrica mandibular nestes pacientes. A outra variável esquelética estudada (PCM-CMM - TABELA 21) não apresentou diferença estatisticamente significante entre os grupos. Resultado diferente do encontrado por ROSE et al. ${ }^{107}$ e $\mathrm{JANSON}^{55}$, onde não foram observadas diferenças significantes para nenhuma das duas variáveis esqueléticas adicionais. A posição lateral dos primeiros molares inferiores e superiores, em relação à borda mandibular, não apresentou diferenças estatisticamente significantes entre os grupos (POSM, POSMS), não evidenciando nenhum posicionamento lateral dos molares na Classe II, subdivisão, dentro de sua base apical, concordando com JANSON ${ }^{55}$.

\subsubsection{RADIOGRAFIA PÓSTERO-ANTERIOR}

No teste $t$ independente (TABELA 22), foi encontrado, apenas, duas variáveis com uma diferença estatisticamente significante entre os grupos de oclusão normal e o grupo com Classe II, subdivisão (B1 e ÂANT). O ângulo antegoniano (ÂANT) demonstra, assim como a variável PCM-LMM (TABELA 
21), um pouco de assimetria esquelética, que talvez justifique a aparência assimétrica mandibular nos pacientes com subdivisão, uma vez que a diferença neste ângulo demonstra que em um lado da mandíbula um ponto deste ângulo está mais alto que do outro, evidenciando uma assimetria entre os lados da mandíbula. Com este resultado podemos observar, o que já foi citado em outros estudos, que a assimetria localiza-se principalmente no terço inferior da face ${ }^{65,116}$ e que apesar de notarmos clinicamente uma assimetria nos indivíduos com Classe II, subdivisão, esta assimetria difere apenas suavemente quando comparamos com um grupo de oclusão normal, pois mesmo estes pacientes apresentam algum grau de assimetria facial ${ }^{36,117}$. De certa forma, a significância da variável B1 vêm suportar uma constatação clínica em pacientes com Classe II, subdivisão, ou seja, a presença em grande parte dos casos de um desvio da linha média dentária inferior, principalmente, ou superior, em relação ao plano sagital mediano. JANSON ${ }^{55}$ também encontrou uma diferença significante para esta variável (B1), contudo o autor também encontrou um resultado significante para a variável $A 1$, resultado este não encontrado neste estudo, talvez isto tenha ocorrido devido ao número reduzido de pacientes pertencentes ao tipo 2 no grupo com Classe II, subdivisão e assimetria facial aparente, onde dos 23 indivíduos pertencentes a este grupo, apenas 4 apresentavam subdivisão do tipo 2.

Foi avaliada a distribuição dos tipos de subdivisão dentro do subgrupo com assimetria facial aparente e a porcentagem obtida foi semelhante àquela realizada em relação ao grupo de subdivisão como um todo, ou seja, não só com assimetria facial aparente. Dos 23 pacientes com assimetria facial aparente, 13 pertenciam ao tipo1 (56,52\%), 4 pertenciam ao tipo $2(17,39 \%)$ e $6(26,08 \%)$ tiveram uma avaliação duvidosa quanto ao tipo de subdivisão, provavelmente devido a uma combinação dos dois tipos anteriores. Demonstrando que o grau de assimetria facial aparente que o indivíduo apresenta não determina o tipo de subdivisão que ele possui, ou seja, o indivíduo que apresenta Classe II, subdivisão e assimetria facial aparente não pertence necessariamente ao tipo 1. 


\subsection{CONSIDERAÇÕES GERAIS}

A correlação entre a assimetria clínica e a assimetria radiográfica encontrada nos grupos estudados foi muito pequena, visto que o grau de assimetria geralmente encontrado é muito suave. Os resultados da comparação entre os indivíduos que apresentavam má oclusão de Classe II, subdivisão e assimetria facial aparente e os indivíduos que apresentavam oclusão normal, demonstraram pouca diferença estatisticamente significante. Possivelmente, este resultado ocorra, pois mesmo os indivíduos com oclusão normal apresentam algum grau de assimetria esquelética e facia| ${ }^{36,117}$ (TABELAS 11 a 22). A participação esquelética encontrada nos indivíduos com Classe II, subdivisão foi muito pequena, mesmo quando há assimetria aparente, quando comparados com os casos de oclusão normal. Concordando com os resultados de estudos anteriores ${ }^{1,55,107}$, que demonstraram que o principal componente da Classe II, subdivisão é dentoalveolar, ocorrendo principalmente por um posicionamento mais distal do molar inferior no lado da Classe II e secundariamente por um posicionamento mais mesial do molar superior deste mesmo lado.

\subsubsection{SUGESTÕES PARA FUTURAS PESQUISAS}

1)- Comparação da assimetria clínica dos pacientes com Classe II, subdivisão e dos pacientes com oclusão normal.

2)- Correlação da assimetria clínica em pacientes com assimetria facial aparente, com Classe II,subdivisão com a assimetria radiográfica. 
7 Conclusões 


\section{CONCLUSÕES}

Os resultados deste trabalho e de acordo com a metodologia utilizada, permitem as seguintes conclusões:

7.1 As correlações entre as medidas das fotografias frontais com as medidas das radiografias foram muito fracas, demonstrando que o grau de assimetria clínica e radiográfica é muito pequeno.

7.2 As más oclusões de Classe II, subdivisão com assimetria facial aparente demonstram ligeira assimetria mandibular radiográfica e maior participação dos elementos dentários, mesmo quando comparados com a oclusão normal, em relação aos casos de Classe II, subdivisão de uma forma geral. 


\section{Referências}

\section{Bibliográficas}




\section{REFERÊNCIAS BIBLIOGRÁFICAS}

1. ALAVI, D. G.; BEGOLE, E. A.; SCHNEIDER, B. J. Facial and dental arch asymmetries in Class II subdivision malocclusion. Amer. J. Orthodont. Dentofac. Orthop, v.93, n.1, p. 38-46, Jan. 1988.

2. ALMEIDA, R. C. de; ALMEIDA, M. H. C. de. A assimetria facial, no exame clínico frontal da face. Ortodontia, v.32, n.2, p. 82-6, maio/jun./jul./ago. 1999.

3. ANGLE, E. H. Classification of malocclusion. Dental Cosmos, v.41, n.3, p. 248-64, Mar. 1899.

4. ANGLE, E. H. Treatment of malocclusion of the teeth and fractures of the maxillae. Anlge's system. 6th ed. Philadelphia, The S.S. White Dental Manufacturing Company, 1900.

5. ANGLE, E. H. Malocclusion of the teeth. 7.ed. Philadelphia, S. S. White, 1907.

6. ARAUJO, T.M. de; MLHELM, R.S.; ALMEIDA, M.A. Skeletal and dental arch asymmetries in Class II division 1 subdivision malocclusions. J. Clin. Pediat. Dent., v.18, n.3, p. 181-5, June 1994.

7. ARNETT, G. W.; BERGMAN, R. T. Facial keys to orthodontic diagnosis and treatment planning. Part I. Amer. J. Orthodont. Dentofac. Orthop, v.103, p. 299-312, Apr. 1993.

8. ARNOLD, T. G.; ANDERSON, G. C.; LILYEMARK, W. F. Assessment of craniofacial asymmetry with S-V radiographs. Amer. J. Orthodont. Dentofac. Orthop, v.106, n.3, p. 250-6, Sept. 1994.

9. ARVYSTAS, M. G.; ANTONELLIS, P.; JUSTIN, A. F. Progressive facial asymmetry as a result of early closure of the coronal suture. Amer. J. Orthodont., v.87, n.3, p. 240-6, Mar. 1985.

10. BAKER, W.L. The influence of the forces of occlusion on the development of the bones of the skull. Int. J. Orthodont. Oral Surg. Radiol., v.8, p. 259, 1922. 
11. BARBER, T. K.; PRUZANSKY, S.; KINDELSPERGER, R. An evaluation of the oblique cephalometric film. J. Dent. Child., v.28, n.2, p. 94-105, 1961.

12. BAUMRIND, S.; FRANTZ, R. The reliability of head film measurements. Amer. J. Orthodont., v.60, p. 111-27, 1971.

13. BERGER, H. Problems and promises of basilar view cephalograms. Angle Orthodont, v.31, n.4, p. 237-45, Oct. 1961.

14. BERGER, H. Progress with basilar view cephalograms. Trans. Europ. Orthodont. Soc., v.40, p. 159-64, 1964.

15. BISHARA, S. E.; BURKEY, P. S.; KHAROUF, J. G. Dental and facial asymmetries: a review. Angle Orthodont., v.64, n.2, p. 89-98, Mar 1994.

16. BISHARA, S. E.; JORGENSEN, G. J.; JAKOBSEN, J. R. Changes in facial dimensions assessed from lateral and frontal photographs. Part I - methodology. Amer. J. Orthodont. Dentofac. Orthop, v.108, p. 389-93, Oct. 1995.

17. BISHARA, S. E. et al. A computer assisted photogrammetric analysis of soft tissue changes after orthodontic treatment. Part I: methodology and reliability. Amer. J. Orthodont. Dentofac. Orthop, v.107, p. 633-9, Jun. 1995.

18. BJÖRK, A.; BJÖRK, L. Artificial deformation and craniofacial asymmetry in ancient peruvians. J. Dent. Res., v.43, n.3, p. 35363, May/June 1964.

19. BRADER, A. C. The application of the priciples of cephalometric laminagraphy to the studies of the frontal planes of the human head. Amer. J. Orthodont., v.35, p. 249-68, 1949.

20. BRASH, J.C.; MCKEAG, H.T.A. The aetiology of irregularity and malocclusion of the teeth. Dental Board of U.K., v.London, 1956 apud SHAH, S.M.; JOSHI, M.R., p. 142,

21. BURSTONE, C. J. Diagnosis and treatment planning of patients with asymmetries. Seminars in Orthodontics, v.4, n.3, p. 153-64, Sept. 1998.

22. CAMPBELL, J. The mylohyoid line in the assessment of facial asymm. Dent. Rec., v.52, n.9-10, p. 204-8, Sept./Oct. 1950. 
23. CHEBIB, F. S.; CHAMMA, A. M. Indices of craniofacial asymmetry. Angle Orthodont, v.51, n.3, p. 214-25, July 1981.

24. CHENEY, E. A. Dentofacial asymmetries and their clinical significance. Amer. J. Orthodont., v.47, n.11, p. 814-29, Nov. 1961.

25. COOK, J. T. Asymmetry of the craniofacial skeleton. Brit. J. Orthodont., v.7, n.1, p. 33-8, Jan. 1980.

26. CRUZ, K. S. Avaliação das alterações dentoesqueléticas decorrentes do tratamento da má-oclusão de Classe II, subdivisão por meio das radiografias submentonianas e póstero-anterior. Bauru, 2000. 208p. Dissertação (Mestrado) Faculdade de Odontologia de Bauru, Universidade de São Paulo.

27. DAHLBERG, G. Statistical methods for medical and biological students. New York, Interscience, 1940.

28. DAVIDSON, T. Photography in facial plastic and reconstructive surgery. J. Biol. Photogr., v.47, p. 59-67, 1979.

29. EDLER, R.; WERTHEIM, D.; GREENHILL, D. Clinical and computerized assessment of mandibular asymmetry. Europ. J. Orthodont., v.23, n.5, p. 485-94, Oct. 2001.

30. ENLOW, D. H.; KURODA, T.; LEWIS, A. B. The morphological and morphogenetic basis for craniofacial form and pattern. Angle Orthodont., v.41, n.3, p. 161-88, July 1971.

31. EPKER, et al. Evaluation and treatment planning. Dentofacial Deformities, v.1, p. 9, 1986.

32. FARKAS, L. G.; CHEUNG, G. Facial asymmetry in healthy north american caucasians. Angle Orthodont, v.51, n.1, p. 70-7, Jan. 1981.

33. FERGUSON, J. W. Cephalometric interpretation and assessment of facial asymmetry secondary to congenital torticolis. Int. J. Oral Maxillofac. Surg., v.22, p. 7-10, 1993.

34. FERRARIO, V. et al. Craniofacial morphometry by photographic evaluations. Amer. J. Orthodont. Dentofac. Orthop., v.103, n.4, p. 327-37, Apr. 1993. 
35. FERREIRA, F. V. Crescimento e desenvolvimento craniofacial. In:FERREIRA, F. V. Ortodontia - diagnóstico e planejamento clínico. 3a ed. São Paulo, Artes Médicas, 1999. Cap. 2. 31-55.

36. FISCHER, B. Asymmetries of the dentofacial complex. Angle Orthodont., v.24, n.4, p. 179-97, Oct. 1954.

37. FORSBERG, C. T.; BURSTONE, C. J.; HANLEY, K. J. Diagnosis and treatment planning of skeletal asymmetry with the submentalvertical radiograph. Amer. J. Orthodont., v.85, n.3, p. 224-37, Mar. 1984.

38. FUSHIMA, K.; INUI, M.; SATO, S. Dental symmetry in temporomandibular disorders. J. Oral Rehabil., v.26, p. 152-6, 1999.

39. GAVAN, J. A.; WASHBURN, S. L.; LEWIS, P. H. Photography: an anhropometric tool. Amer. J. phys. Anthrop., v.10, p. 331-53, 1952.

40. GIAMBATTISTINI, C. Evaluation of accuracy of the $45^{\circ}$ oblique and corrected oblique in assessing mandibular asymmetry. Toronto, 1997. 130p. Master's Thesis - University of Toronto.

41. GILBERT, D. H. A radiographic method of basilar cephalometrics. Amer. J. Orthodont., v.46, n.5, p. 384-5, May 1960.

42. GRAVELY, J. F.; BENZIES, P. M. The clinical significance of tracing error in cephalometry. Brit. J. Orthodont., v.1, p. 95-101, 1974.

43. GRAYSON, B.H.; McCARTHY, J.G.; BOOKSTEIN, F. Analysis of craniofacial asymmetry by multiplane cephalometry. Amer. J. Orthodont., v.84, n.3, p. 217-23, Sept. 1983.

44. GRAYSON, B.H. et al. Basilar multiplane cephalometric analysis. Amer. J. Orthodont., v.88, n.6, p. 503-16, Dec. 1985.

45. GRUMMONS, D. C.; VAN DE COPPELLO, M. A. K. A frontal asymmetry analysis. J. clin. Orthodont., v.21, n.7, p. 448-65, July 1987.

46. HARVOLD, E. P. The asymmetries of the upper facial skeleton and their morphological significance. Trans. Europ. Orthodont. Soc., p. 63-9, 1951. 
47. HARVOLD, E. P. A roentgen study of the postnatal morphogenesis of the facial skeleton in cleft palate. Oslo, 1954. Masters Thesis - University of Oslo.

48. HASSE, C. apud LUNDSTRÖM, A. Some asymmetries of the dental arches, jaws, and skull, and their etiological significance. Amer. J. Orthodont., v.47, n.2, p. 81-106, Feb. 1961.

49. HATTON, M. E.; GRAINGER, R. M. Reliability of measurements from cephalograms at the Burlington Orthodontic Research Centre. J. Dent. Res., v.37, n.5, p. 853-9, Sept./Oct. 1958.

50. HERZBERG, B. L. Facial esthetics in relation to orthodontic treatment. Angle Orthodont., v.22, n.1, p. 3-22, Jan. 1952.

51. HOUSTON, W. J. B. The analysis of errors in orthodontic measurements. Amer. J. Orthodont., v.83, n.5, p. 382-90, May 1983.

52. HULSEY, C.M. An esthetic evaluation of lip-teeth relationships present in the smile. Amer. J. Orthodont., v.57, n.2, p. 132-43, Feb. 1970.

53. INUI, M.; FUSHIMA, K.; SATO, S. Facial symmetry in internal derangement of temporomandibular joint disorders. Europ. J. Orthodont., v.16, p. 456 (Abstracts), 1994.

54. JACKSON, A. F. Facts, fictions and fallacies in orthodontia. Amer. J. Orthodont., v.23, p. 1073-95, 1937.

55. JANSON, G. R. P. Estudo tridimensional das assimetrias dentárias e esqueléticas na má-oclusão de Classe II, subdivisão. Bauru, 1998. 271p. Tese (Livre-Docência) Faculdade de Odontologia de Bauru, Universidade de São Paulo.

56. JANSON, G. R. P et al. Three-dimensional evaluation of skeletal and dental asymmetries in Class II subdivision malocclusions. Amer. J. Orthodont. Dentofac. Orthop., v.119, n.4, p. 406-18, Apr. 2001.

57. JANSON, G. R. P.; METAXAS, A.; WOODSIDE, D. G. Variation in maxillary and mandibular molar and incisor vertical dimension in 12-year-old subjects with excess, normal and short lower anterior 
face height. Amer. J. Orthodont. Dentofac. Orthop, v.106, n.4, p. 409-18, Oct. 1994.

58. JERROLD, L.; LOWENSTEIN, L. J. The midline: diagnosis and treatment. Amer. J. Orthodont. Dentofac. Orthop., v.97, n.6, p. 453-62, June 1990.

59. KANTOMAA, T. The relation between mandibular configuration and the shape of the glenoid fossa in the human. Europ. J. Orthodont., v.11, p. 77-81, 1989.

60. KELLY, M.F. Light-wire treatment of a Class II, Division 1 subdivision malocclusion. Amer. J. Orthodont., v.89, n.3, p. 216-22, Mar. 1986.

61. KONDO, E.; AOBA, T. J. Case report of malocclusion with abnormal head posture and TMJ symptoms. Amer. J. Orthodont. Dentofac. Orthop, v.116, n.5, p. 481-93, Nov. 1999.

62. KRONMILLER, J. E. Development of asymmetries. Seminars in Orthodontics, v.4, n.3, p. 134-7, Sept. 1998.

63. KURZ, C. S. A practical method of producing roentgenograms for diagnosis and treatment of temporomandibular lesions. Dent. J., v.12, p. 446-50, 1943.

64. LAM, P.H.; SADOWSKY, C.; OMERZA, F. Mandibular asymmetry and condylar position in children with unilateral posterior crossbite. Amer. J. Orthodont. Dentofac. Orthop., v.115, n.5, p. 569-75, May 1999.

65. LEGAN, H. L. Surgical correction of patients with asymmetries. Seminars in Orthodontics, v.4, n.3, p. 189-98, Sept. 1998.

66. LEGRELL, P.E.; ISBERG, A. Mandibular length and midline asymmetry after experimentally induced temporomandibular joint disk displacement in rabbits. Amer. J. Orthodont. Dentofac. Orthop., v.115, n.3, p. 247-53, Mar. 1999.

67. LETZER, G. M.; KRONMAN, J. H. A posteroanterior cephalometric evaluation of craniofacial asymmetry. Angle Orthodont, v.37, n.3, p. 205-11, July 1967. 
68. LEW, K.K.K.; TAY, D.K.L. Submentovertex cephalometric norms in male Chinese subjects. Amer. J. Orthodont. Dentofac. Orthop., v.103, n.3, p. 247-52, Mar. 1993.

69. LEWIS, P. D. The deviated midline. Amer. J. Orthodont., v.70, n.6, p. 601-16, Dec. 1976.

70. LUNDSTRÖM, A. Some asymmetries of the dental arches, jaws, and skull, and their etiological significance. Amer. J. Orthodont., v.47, n.2, p. 81-106, Feb. 1961.

71. MARKEY, R. J.; POTTER, B. E.; MOFFETT, B. C. Condylar trauma and facial asymmetry: an experimental study. J. Maxillofac. Surg., v.8, p. 38-51, 1980.

72. MARMARY, Y.; SILBERMAN, Y.; MIRSKY, Y. Use of foramina spinosa to determinate skull midlines. Angle Orthodont., v.49, n.4, p. 263-8, Apr. 1979.

73. MAURICE, T. J.; KULA, K. Dental arch asymmetry in the mixed dentition. Angle Orthodont, v.68, n.1, p. 37-44, Feb. 1998.

74. MELNIK, A. K. A cephalometric study of mandibular asymmetry in a longitudinally followed sample of growing children. Amer. J.

Orthodont. Dentofac. Orthop., v.101, n.4, p. 355-66, Apr. 1992.

75. MERRILL, V. Atlas of roentgenographic positions. St. Louis, The C. V. Mosby Company, 1949.

76. METAXAS, A. A radiographic study for the assessment of mandibular asymmetry. Athens, 1993. PhD Thesis - University of Athens.

77. MILLS, L. apud SUTTON, P. Lateral facial asymmetry - methods of assessment. Angle Orthodont, v.38, n.1, p. 82-92, Jan. 1968.

78. MONGINI, F. Remodelling of the temporomandibular condyle in the adult and its relationship to the conditions of the dental arches. Acta anat., v.82, p. 292-300, 1972.

79. MONGINI, F.; SCHMID, W. Treatment of mandibular asymmetries during growth: a longitudinal study. Europ. J. Orthodont., v.9, n.1, p. 51-67, Feb 1987. 
80. MOORE, G. R.; HUGHES, B. O. Familial factors in diagnosis, treatment, and prognosis of dentofacial disturbancies. Amer. J. Orthodont. Dentofac. Orthop., v.28, n.10, p. 603-39, Oct. 1942.

81. MOORREES, C. F. A.; KEAN, Mr. Natural head position, a basic consideration in the interpretation of cephalometric radiographs. Am. J. Phys. Antropol., v.16, p. 213-34, 1956.

82. MOSS, M. I.; SALENTIJN, I. Differences between the functional matrices in the anterior open bite and in deep overbite. Amer. J. Orthodont. Dentofac. Orthop, v.60, n.6, p. 264-80, Sept. 1971.

83. MULICK, J.F. An investigation of craniofacial asymmetry using the serial twin-study method. Amer. J. Orthodont., v.51, n.2, p. 11229, Feb. 1965.

84. NAHOUM, H. I.; FIASCONARO, J.; DI SALVO, N. A. The verticosubmental roentgenogram in cephalometrics. J. Amer. Dent. Assoc., v.69, p. 133-50, Aug. 1964.

85. NELSON, N. E.; HIGLEY, L. B. The lenght of mandibular basal bonein normal occlusion and Class I malocclusion compared to Class II, division 1 malocclusion. Amer. J. Orthodont., v.34, p. 610-7, 1948.

86. O'BYRN, B. L. et al. An evaluation of mandibular asymmetry in adults with unilateral posterior crossbite. Amer. J. Orthodont. Dentofac. Orthop., v.107, n.4, p. 394-400, Apr. 1995.

87. OGAARD, B.; KROGSTAD, O. Craniofacial structure and soft tissue profile in patients with severe hypodontia. Amer. J. Orthodont. Dentofac. Orthop, v.108, n.5, p. 472-7, Nov. 1995.

88. OUSTERHOUT, D.K.; VARGERVIK, K. Maxillary hypoplasia secondary to midfacial trauma in childhood. Plast. Reconstr. Surg., v.80, p. 491-9, 1987.

89. PANOFSKY, E. apud SUTTON, P. Lateral facial asymmetry Methods of assessment. Angle Orthodont, v.38, n.1, p. 82-92, Jan. 1968.

90. PEARSON, K.; WOO, T. L. Further investigation of the morphometric characters of the individual bones of he human skull. Biometrika, v.27, p. 424-65, 1935. 
91. PECK, S.; PECK, L.; KATAJA, M. Skeletal asymmetry in esthetically pleasing faces. Angle Orthodont, v.61, n.1, p. 43-8, Spring 1991.

92. PELTOLA, J. L.; KONUNEM, M.; NYSTROM, M. Radiographic characteristics in mandibular condyles of orthodontic patients before treatment. Europ. J. Orthodont., v.17, n.1, p. 69-77, Feb. 1995.

93. PETRILLI, A.; GURLEY, J. E. Tomography of the temporomandibular joint. J. Am. Dent. Assoc., v.26, p. 218-24, 1939.

94. PIRTTINIEMI, P. Normal and increased functional asymmetries in the craniofacial area. Acta Odont. Scand., v.56, n.6, p. 342-5, Dec. 1998.

95. PIRTTINIEMI, P.; KANTOMAA, T. Relation of glenoid fossa morphology to mandibulofacial asymmetry, studied in dry human lapp skulls. Acta Odont. Scand., v.50, n.4, p. 235-43, Aug. 1992.

96. PIRTTINIEMI, P. et al. Relationships of bicondylar position to oclusal asymmetry. Europ. J. Orthodont., v.13, n.6, p. 441-5, Dec. 1991.

97. PIRTTINIEMI, P. M. Associations of mandibular and facial asymmetries - a review. Amer. J. Orthodont. Dentofac. Orthop, v.106, p. 191-200, Aug. 1994.

98. POLLARD, L. E.; MAMANDRAS, A. H. Male postpubertal facial growth in Class II malocclusions. Amer. J. Orthodont. Dentofac. Orthop, v.108, n.1, p. 62-8, July 1995.

99. PONYI, S.; SZABÓ, G.; NYILASI, J. Asymmetry of mandibular dimensions in european skulls. Proc. Fin. Dent. Soc., v.87, n.3, p. 321-7, July 1991.

100. PROFFIT, W.R.; VIG, K.W.L.; TURVEY, T.A. Early fracture of the mandibular condyles: Frequently an unsuspected cause of growth disturbances. Amer. J. Orthodont., v.78, n.1, p. 1-24, July 1980.

101. PULLINGER, A. G. et al. Relationship of mandibular condylar position to dental occlusion factors in an asymptomatic population. Amer. J. Orthodont. Dentofac. Orthop., v.91, n.3, p. 200-6, Mar. 1987.

102. REBELLATO, J. Asymmetric extractions used in the treatment of patients with asymmet. Seminars in Orthodontics, v.4, n.3, p. 180-8, Sept. 1998. 
103. RICHARDSON, A. An investigation into the reproducibility of some points, planes, and lines used in cephalometric analysis. Amer. J. Orthodont., v.52, p. 637-51, 1966.

104. RICHARDSON, A. A comparision of traditional and computadorized method of cephalometric analysis. Europ. J. Orthodont., v.3, p. 15-20, 1981.

105. RICKETTS, R. M. Present status of laminagraphy as related to dentistry. J. Am. Dent. Assoc., v.65, p. 56-64, 1962.

106. RITTUCCI, R.; BURSTONE, C. J. Use of the submental vertical radiograph in the assessment of asymmetry. Farmington, 1981. Certificate in Orthodontics - Department of Orthodontics, University of Connecticut.

107. ROSE, J. M. et al. Mandibular skeletal and dental asymmetry in Class II subdivision malocclusions. Amer. J. Orthodont. Dentofac. Orthop., v.105, n.5, p. 489-95, May 1994.

108. ROSEN, M. D.; BUTCHER, E. O.; SILVERMAN, S. I. Muscle and skull development changes in gods with induced unilateral anodontia. Oral Surg., v.3, p. 672-5, Nov. 1965.

109. ROTH, R. H. Functional occlusion for the orthodontist. J. clin. Orthodont., v.15, n.1, p. 32-51, Jan. 1981.

110. RUNE, B. et al. Roentgen stereometry with the aid of metallic implants in hemifacial microsomia. Amer. J. Orthodont., v.84, n.3, p. 231-47, Sept. 1983.

111. SASSOUNI, V. Position of the maxillary first permanent molar in the cephalofacial complex. Amer. J. Orthodont., v.43, n.7, p. 477510, July 1957.

112. SCAVONE JÚNIOR, H. O perfil facial tegumentar dos 13 aos 18 anos de idade. Bauru, 1996. 217p. Tese (Mestrado) - Faculdade de Odontologia de Bauru, Universidade de São Paulo.

113. SCHELLHAS, K. P.; PIPER, M. A.; OMLIE, M. R. Facial skeleton remodeling due to temporomandibular joint degeneration: an imaging study of 100 patients. Am. J. Neuroradiol., v.11, p. 541$51,1990$. 
114. SCHMID, W.; MONGINI, F.; FELISIO, A. A computer-based assessment of structural and displacement asymmetries of the mandible. Amer. J. Orthodont. Dentofac. Orthop., v.100, n.1, p. 19-34, July 1991.

115. SCHUELLER, A. apud GRAYSON, B.H.; McCARTHY, J.G.; BOOKSTEIN, F. Analysis of craniofacial asymmetry by multiplane cephalometry. Amer. J. Orthodont., v.84, n.3, p. 217-24, Sept. 1983.

116. SEVERT, T. R.; PROFFIT, W. R. The prevalence of facial asymmetry in the dentofacial deformities population at the University of North Carolina. Int. J. Adult. Orthodont. Orthognat. Surg., v.12, n.3, p. 171-6, 1997.

117. SHAH, S. M.; JOSHI, M. R. An assessment of asymmetry in the normal craniofacial complex. Angle Orthodont., v.48, n.2, p. 1417, Apr. 1978.

118. SHEATS, R. D. et al. Prevalence of orthodontic asymmetries. Seminars in Orthodontics, v.4, n.3, p. 138-45, Sept. 1998.

119. SHROFF, B.; SIEGEL, S. M. Treatment of patients with asymmetries using asymmetric mechanics. Seminars in Orthodontics, v.4, n.3, p. 165-79, Sept. 1998.

120. SHROFF, B.; LINDAUER, S.J.; BURSTONE, C.J. Class II subdivision treatment with tip-back moments. Europ. J. Orthodont., v.19, n.1, p. 93-101, Feb. 1997.

121. SILVA FILHO, O. G. et al. Prevalência de oclusão normal e máoclusão em escolares da cidade de Bauru (São Paulo). Parte I: relação sagital. Rev. Odont. USP, v.4, n.2, p. 130-7, abr./jun. 1990.

122. SIMON, P.W. apud SUTTON, P.R. Lateral facial asymmetry methods of assessment. Angle Orthodont, v.38, n.1, p. 82-92, Jan. 1968.

123. SKOLNICK, J. et al. Prepubertal trauma and mandibular asymmetry in orthognathic surgery and orthodontic patients. Amer. J. Orthodont. Dentofac. Orthop, v.105, n.1, p. 73-7, Jan. 1994. 
124. SLAVICEK, R. JCO/Interviews: on clinical and instrumental functional analysis for diagnosis and treatment planning Part1. J. clin. Orthodont., v.22, n.6, p. 358-70, June 1988.

125. SUBTELNY, J. D. The degenerative, regenerative mandibular condyle: facial asymmetry. J. Craniofacial Genet. Dev. Bio. Suppl., v.1, p. 227-37, 1985.

126. SUGUINO, R. et al. Análise facial. Rev. Dental Press Ortodon. Ortop. Facial, v.1, n.1, p. 86-107, set./out. 1996.

127. SUTTON, P. R. N. Lateral facial asymmetry - Methods of assessment. Angle Orthodont, v.38, n.1, p. 82-92, Jan. 1968.

128. SVED, A. An analysis of the most important diagnostic methods used in orthodontia. Angle Orthodont., v.1, p. 139-60, 1931.

129. TALLENTS, R. H. et al. Angular and linear comparisions with unilateral mandibular asymmetry. J. craniomandibular dis. fac. oral pain, v.5, n.2, p. 135-41, May 1991.

130. THATCHER, R.W.; WALKER, R.A.; Giudice, S. Human cerebral hemispheres develop at different rates and ages. Science, v.236, p.1110-3, 1987 apud PIRTTINIEMI, P.M. Associations of mandibular and facial asymmetries - a review. Amer. J. Orthodont. Dentofac. Orthop, v.106, p. 191-200, ago. 1994.

131. THOMPSON, J. R. Asymmetry of the face. J. Am. Dent. Assoc., v.30, p. 1859-71, Dec. 1943.

132. VAZQUEZ, F. et al. Eccentricity of the skull: correlation with dental malocclusion. Angle Orthodont, v.52, n.2, p. 144-58, Apr. 1952.

133. VIAZIS, A. D. The cranial base triangle. J. clin. Orthodont., v.25, p. 565-70, 1991.

134. VIG, P. S.; HEWITT, A. B. Asymmetry of the human facial skeleton. Angle Orthodont, v.45, n.2, p. 124-9, Apr. 1975.

135. WARREN, D.W. Subdivision malocclusions: cracking the riddle. J. clin. Orthodont., v.35, n.2, p. 93-9, Feb. 2001.

136. WERTZ, R. A. Diagnosis and treatment planning of unilateral Class II malocclusion. Angle Orthodont., v.45, n.2, p. 85-94, Apr. 1975.

137. WILLIAMS, R. Positioning and lighting for patient photography. J. Biol. Photogr., v.53, p. 131-43, 1985. 
138. WILLIAMSON, E. H. JCO/Interviews: occlusion and TMJ dysfunction. J. clin. Orthodont., v.15, n.5, p. 333-50, May 1981.

139. WILLIAMSON, E. H. JCO/Interviews: occlusion and TMJ dysfunction (Part 2). J. clin. Orthodont., v.15, n.6, p. 393-410, June 1981.

140. WILLIAMSON, E. H.; SIMMONS, M. D. Mandibular asymmetry and its relation to pain dysfunction. Amer. J. Orthodont., v.76, n.6, p. 612-7, Dec. 1979.

141. WILLIAMSON, E.H.; WILSON, C.W. Use of a submental-vertex analysis for producing quality temporomandibular joint laminagraphs. Amer. J. Orthodont., v.70, n.2, p. 200-7, Aug. 1976.

142. WOO, T. L. On the asymmetry of the human skull. Biometrika, v.22, p. 324-52, 1931.

143. WOO, T. L. A biometric study of the human malar bone. Biometrika, v.29, p. 113-23, 1937-38.

144. WOODSIDE, D. G. The diagnosis and treatment of mandibular asymmetry. 1990. - University of Toronto, Department of Continuing Education. 
Abstract 


\section{CORRELATION BETWEEN CLINICAL ASYMMETRY AND RADIOGRAPHIC ASYMMETRY IN PATIENTS WITH CLASS II SUBDIVISION MALOCCLUSION}

The primary objective of this study was to evaluate the correlation between clinical asymmetry and radiographic asymmetry in patients with Class II subdivision malocclusion. Secondarily, the degree of skeletal asymmetries between patients with this type of malocclusion that also presented apparent facial asymmetry were compared to the degree of asymmetry of subjects with normal occlusion. The sample consisted of 42 individuals with complete Class II subdivision malocclusion and 30 with normal occlusion. The mean age of the subjects was 15.21 and 22.42 years for the Class II subdivision group and the normal occlusion group, respectively. Clinical asymmetry was assessed by measuring the relative difference in spatial position of soft tissue landmarks between right and left sides in frontal photographs. Radiographic asymmetry was assessed by measuring the relative difference in spatial position of dental and skeletal landmarks between right and left sides in both anteroposterior and transverse dimensions in the submentovertex and in the transverse and vertical dimensions in the postero-anterior radiographs. Pearson's correlation test was performed between the asymmetries in the photographs and the asymmetries in the radiographs. Independent $t$ tests were used to compare the radiographic asymmetries of 23 Class II subdivision subjects that also presented apparent facial asymmetry with subjects with normal occlusion. The correlation between clinical and radiographic asymmetry was very weak. Despite the predominantly dentoalveolar nature of the asymmetries found in Class II, subdivision malocclusions with apparent facial asymmetry, there was a small radiographic mandibular asymmetry in relation to Class II, subdivision malocclusions in general. 


\section{APÊNDICE}

TABELA A-1 - Característica dos indivíduos do grupo com Classe II, subdivisão.

\begin{tabular}{|c|c|c|c|c|c|}
\hline \multicolumn{6}{|c|}{ CLASSE II, SUBDIVISÃO } \\
\hline Paciente & D.N. & Data $R x$ & Idade & Direito & Esquerdo \\
\hline 1- A.B. & 14.08 .83 & 13.04 .96 & 12,67 & CL.I & CL.II \\
\hline 2-A.E. & 19.03 .81 & 12.12 .95 & 14,74 & CL.I & CL.II \\
\hline 3- A.N.P.M. & 12.07 .80 & 13.04 .96 & 15,76 & CL.I & CL.II \\
\hline 4- A.L.G.S. & 29.04 .84 & 12.06 .96 & 12,12 & CL.II & CL.I \\
\hline 5- A.P.F.R. & 06.08 .73 & 13.04 .96 & 22,70 & CL.I & CL.II \\
\hline 6- A.G. & 19.05 .76 & 10.08 .96 & 20,24 & CL.II & CL.I \\
\hline 7- A.C.M.Jr. & 05.11 .83 & 06.04 .96 & 12,42 & CL.I & CL.II \\
\hline 8- B.P.L. & 12.05 .83 & 02.06 .95 & 12,06 & CL.I & CL.II \\
\hline 9- B.L.M.E. & 03.09 .86 & 10.06 .02 & 15,75 & CL.II & CL.I \\
\hline 10- C.Q. & 10.10 .83 & 02.04 .96 & 12,48 & CL.I & CL.II \\
\hline 11- C.B.S. & 25.07 .80 & 30.03 .96 & 15,69 & CL.I & CL.II \\
\hline 12- C.A.A. & 09.06 .76 & 07.10 .95 & 19,33 & CL.II & CL.I \\
\hline 13- D.F.R.S. & 05.05 .79 & 14.02 .96 & 16,79 & CL.I & CL.II \\
\hline 14- D.M.B. & 04.09 .76 & 15.02 .96 & 19,46 & CL.II & CL.I \\
\hline 15- D.M.R. & 27.04 .64 & 26.03 .96 & 31,93 & CL.I & CL.II \\
\hline 16- E.Y.Y. & 06.02 .83 & 06.04 .96 & 13,17 & CL.I & CL.II \\
\hline 17- E.P. & 03.03 .81 & 04.04 .96 & 15,09 & CL.II & CL.I \\
\hline 18- E.A.S. & 07.09 .88 & 01.02 .02 & 13,41 & CL.II & CL.I \\
\hline 19- F.S.S. & 11.05 .83 & 06.04 .96 & 12,91 & CL.I & CL.II \\
\hline 20-G.N.T. & 20.06 .88 & 11.03 .02 & 13,75 & CL.I & CL.II \\
\hline 21- G.F.M.C. & 08.07 .88 & 01.02 .02 & 13,58 & CL.I & CL.II \\
\hline 22- I.R.C. & 19.05 .87 & 05.02 .02 & 14,75 & CL.I & CL.II \\
\hline 23- I.A. & 22.09 .81 & 19.06 .95 & 13,74 & CL.II & CL.I \\
\hline 24- J.W.M.O. & 22.10 .89 & 04.02 .02 & 12,33 & CL.I & CL.II \\
\hline 25- L.A.S. & 02.09 .89 & 01.02 .02 & 12,41 & CL.II & CL.I \\
\hline 26- L.C.M.F. & 06.04 .88 & 29.04 .02 & 14,00 & CL.I & CL.II \\
\hline 27- L.C.S.S. & 20.10 .83 & 09.02 .96 & 12,31 & CL.II & CL.I \\
\hline 28- M.A.O.F. & 26.09 .81 & 08.02 .96 & 14,37 & CL.II & CL.I \\
\hline 29- M.M.S. & 01.08 .82 & 06.04 .96 & 13,69 & CL.II & CL.I \\
\hline 30- N.C.R. & 20.06 .83 & 06.04 .96 & 12,80 & CL.II & CL.I \\
\hline 31- P.S.D. & 02.02 .81 & 30.03 .96 & 15,16 & CL.II & CL.I \\
\hline 32- R.M.G. & 04.05 .83 & 06.04 .96 & 12,93 & CL.II & CL.I \\
\hline 33- R.Z. & 27.12 .81 & 22.04 .02 & 20,33 & CL.I & CL.II \\
\hline 34- R.S. & 17.12 .86 & 01.02 .02 & 15,16 & CL.II & CL.I \\
\hline 35- R.C.M. & 07.01 .79 & 08.02 .96 & 17,09 & CL.I & CL.II \\
\hline 36- R.D.P. & 07.08 .81 & 19.06 .95 & 13,87 & CL.I & CL.II \\
\hline 37- S.F.A. & 07.05 .84 & 30.03 .96 & 11,90 & CL.II & CL.I \\
\hline 38- S.A.P. & 30.01 .76 & 08.06 .96 & 20,36 & CL.I & CL.II \\
\hline 39- T.L.D. & 28.03 .88 & 18.02 .02 & 13,91 & CL.II & CL.I \\
\hline 40- V.R.R.F. & 27.05 .89 & 05.02 .02 & 12,75 & CL.II & CL.I \\
\hline 41-W.M.S. & 21.10 .89 & 05.02 .02 & 12,33 & CL.II & CL.I \\
\hline 42- W.R.C. & 19.12 .78 & 02.06 .95 & 16,46 & CL.I & CL.II \\
\hline Média & & & 15,21 & & \\
\hline
\end{tabular}


TABELA A-2 - Característica dos indivíduos do grupo com oclusão normal.

\begin{tabular}{|c|c|c|c|c|c|}
\hline \multicolumn{6}{|c|}{ OCLUSÃO NORMAL } \\
\hline Paciente & D.N. & Data $R x$ & Idade & Direito & Esquerdo \\
\hline 1- A.C.J.P. & 27.02 .67 & 26.10 .95 & 28,67 & Relação Normal & Relação Normal \\
\hline 2- A.C.M. & 16.05 .81 & 18.06 .96 & 15,10 & Relação Normal & Relação Normal \\
\hline 3-A.E.A. & 09.04 .74 & 08.04 .96 & 22,01 & Relação Normal & Relação Normal \\
\hline 4- A.T.N. & 27.10 .80 & 31.08 .96 & 15,85 & Relação Normal & Relação Normal \\
\hline 5- A.C.R. & 30.10 .75 & 10.08 .96 & 20,79 & Relação Normal & Relação Normal \\
\hline 6- A.M.K. & 08.07 .76 & 10.08 .96 & 20,10 & Relação Normal & Relação Normal \\
\hline 7- C.A.C. & 25.05 .77 & 28.06 .96 & 19,10 & Relação Normal & Relação Normal \\
\hline 8- C.F. & 15.07 .68 & 25.04 .95 & 26,79 & Relação Normal & Relação Normal \\
\hline 9- C.J.C. & 20.08 .80 & 26.10 .95 & 15,19 & Relação Normal & Relação Normal \\
\hline 10- D.S.M. & 01.12 .79 & 13.07 .96 & 16,62 & Relação Normal & Relação Normal \\
\hline 11- D.A.A. & 08.04 .73 & 24.08 .96 & 23,39 & Relação Normal & Relação Normal \\
\hline 12- F.Y. & 25.08 .75 & 24.08 .96 & 21,01 & Relação Normal & Relação Normal \\
\hline 13- F.G.A. & 30.08 .69 & 30.03 .96 & 26,60 & Relação Normal & Relação Normal \\
\hline 14- F.P.A.Jr. & 13.11 .72 & 10.08 .96 & 23,75 & Relação Normal & Relação Normal \\
\hline 15- H.F.S. & 19.02 .80 & 21.11 .95 & 15,76 & Relação Normal & Relação Normal \\
\hline 16- J.R.P. & 27.07 .78 & 21.03 .96 & 17,66 & Relação Normal & Relação Normal \\
\hline 17- J.K. & 24.06 .75 & 13.04 .96 & 20,81 & Relação Normal & Relação Normal \\
\hline 18- J.L.D. & 30.06 .76 & 20.04 .96 & 19,81 & Relação Normal & Relação Normal \\
\hline 19- L.M.C. & 15.04 .72 & 04.06 .96 & 24,15 & Relação Normal & Relação Normal \\
\hline 20- M.R.F. & 17.12 .75 & 16.03 .96 & 20,26 & Relação Normal & Relação Normal \\
\hline 21-M.C.R.M. & 14.04 .76 & 01.06 .96 & 20,14 & Relação Normal & Relação Normal \\
\hline 22- M.H.D. & 16.03 .55 & 28.03 .96 & 41,06 & Relação Normal & Relação Normal \\
\hline 23- M.F. & 12.08 .72 & 19.04 .96 & 23,70 & Relação Normal & Relação Normal \\
\hline 24- N.Z.V. & 13.12 .63 & 20.10 .95 & 31,87 & Relação Normal & Relação Normal \\
\hline 25- R.T. & 03.10 .71 & 20.10 .95 & 24,06 & Relacão Normal & Relação Normal \\
\hline 26- R.P. & 02.05 .65 & 01.06 .96 & 31,10 & Relação Normal & Relação Normal \\
\hline 27- R.B.F.A. & 24.09 .71 & 24.08 .96 & 24,93 & Relação Normal & Relação Normal \\
\hline 28- S.H. & 19.01 .73 & 16.03 .96 & 23,16 & Relação Normal & Relação Normal \\
\hline 29- S.B. & 02.05 .77 & 28.06 .96 & 19,16 & Relação Normal & Relação Normal \\
\hline 30- V.A.R.F. & 28.01 .76 & 25.04 .96 & 20,25 & Relação Normal & Relação Normal \\
\hline Média & & & 22,42 & & \\
\hline
\end{tabular}


TABELAS A-3 e A-4 - Valores reais individuais de cada variável, para as medidas das fotografias frontais, para cada indivíduo com Classe II, subdivisão (Grupo 1)

\begin{tabular}{|c|c|c|c|c|c|c|c|c|c|}
\hline Paciente & Número & Grupo & Gênero & $\mathrm{Me}$ & Sbn & ZyD-Me & ZyE-Me & GoD-Me & GoE-Me \\
\hline 1- A.B. & 1 & 1 & $M$ & 1 & 1,2 & \begin{tabular}{|l|}
70,3 \\
\end{tabular} & 70,6 & 37,2 & 35,8 \\
\hline 2- A.E. & 2 & 1 & $\mathrm{~F}$ & 0,3 & $-0,4$ & 63,3 & 60,9 & 35,5 & 34,5 \\
\hline 3- A.N.P.M. & 3 & 1 & $\mathrm{~F}$ & 2,6 & 0,2 & 78,2 & 75,3 & 44,6 & 41,4 \\
\hline 4- A.L.G.S. & 4 & 1 & $\mathrm{~F}$ & 0,9 & $-0,7$ & 78,5 & 77,9 & 44,8 & 43,3 \\
\hline 5- A.P.F.R. & 5 & 1 & $\mathrm{~F}$ & 1,2 & 0,3 & 72,8 & 73,6 & 39 & 39,5 \\
\hline 6- A.G. & 6 & 1 & $M$ & 0,4 & $-0,7$ & 80,3 & 80,9 & 45,2 & 43,1 \\
\hline 7- A.C.M.Jr. & 7 & 1 & $M$ & $-0,4$ & 0,2 & 71,2 & 71,1 & 39,4 & 38,5 \\
\hline 8- B.P.L. & 8 & 1 & $\mathrm{~F}$ & $-0,1$ & $-1,6$ & 74,6 & 73,1 & 40,3 & 40 \\
\hline 9- B.L.M.E. & 9 & 1 & $\mathrm{~F}$ & 0,7 & $-0,4$ & 86,4 & 85,5 & 41,7 & 40,6 \\
\hline 10- C.Q. & 10 & 1 & $\mathrm{~F}$ & $-0,6$ & $-1,1$ & 67,5 & 66,9 & 39,6 & 38,9 \\
\hline 11- C.B.S. & 11 & 1 & $M$ & -1 & $-1,9$ & 71 & 73,1 & 41,3 & 42,2 \\
\hline 12- C.A.A. & 12 & 1 & $M$ & 0,3 & $-0,4$ & 71,5 & 72,8 & 39,9 & 39,3 \\
\hline 13- D.F.R.S. & 13 & 1 & $M$ & 0,2 & 0,7 & 72,4 & 72,7 & 43 & 43,6 \\
\hline 14- D.M.B. & 14 & 1 & $\mathrm{~F}$ & -1 & $-0,5$ & 77,7 & 76,7 & 40,4 & 38,9 \\
\hline 15- D.M.R. & 15 & 1 & $\mathrm{~F}$ & 0,5 & $-0,3$ & 77,1 & 76,2 & 43,2 & 43,1 \\
\hline 16- E.Y.Y. & 16 & 1 & $M$ & $-1,2$ & -1 & 79,9 & 79,2 & 40,3 & 44,1 \\
\hline 17- E.P. & 17 & 1 & $\mathrm{~F}$ & 0,1 & $-0,8$ & 74,8 & 74,9 & 38,5 & 37,1 \\
\hline 18- E.A.S. & 18 & 1 & $\mathrm{M}$ & 0 & $-0,7$ & 80,6 & 82,1 & 38 & 39,6 \\
\hline 19- F.S.S. & 19 & 1 & $M$ & 0,2 & 0,5 & 73,9 & 73,9 & 39,2 & 40,2 \\
\hline 20- G.N.T. & 20 & 1 & $M$ & 0,8 & 0,1 & 78,1 & 77,1 & 40,4 & 38,1 \\
\hline 21- G.F.M.C. & 21 & 1 & $\mathrm{~F}$ & 0,8 & 1,2 & 80,6 & 80 & 37,6 & 37,4 \\
\hline 22- I.R.C. & 22 & 1 & $\mathrm{~F}$ & $-0,4$ & $-0,2$ & 77,5 & 76,8 & 39,9 & 38,7 \\
\hline 23- I.A. & 23 & 1 & $M$ & $-1,1$ & 0,1 & 80,3 & 80,8 & 44,7 & 45 \\
\hline 24- J.W.M.O. & 24 & 1 & $M$ & 1,8 & $-0,4$ & 74,7 & 72,5 & 36,4 & 33,8 \\
\hline 25- L.A.S. & 25 & 1 & $\mathrm{~F}$ & 0,8 & 0,9 & 81,7 & 81,5 & 42,9 & 41,9 \\
\hline 26- L.C.M.F. & 26 & 1 & $M$ & 0,4 & 0,2 & 73 & 72,9 & 35,5 & 36,3 \\
\hline 27- L.C.S.S. & 27 & 1 & $M$ & 0 & $-0,5$ & 66,3 & 67,9 & 32,8 & 34 \\
\hline 28- M.A.O.F. & 28 & 1 & $M$ & -1 & 0,4 & 70,1 & 70,2 & 39,9 & 37,8 \\
\hline 29- M.M.S. & 29 & 1 & $\mathrm{~F}$ & $-1,1$ & 0,4 & 75,1 & 76,9 & 40,6 & 42,6 \\
\hline 30- N.C.R. & 30 & 1 & $\mathrm{~F}$ & 1 & 0,5 & 77,2 & 77 & 42,2 & 42,6 \\
\hline 31- P.S.D. & 31 & 1 & $\mathrm{~F}$ & 1,5 & 1,7 & 77,8 & 76,9 & 43 & 39,3 \\
\hline 32- R.M.G. & 32 & 1 & $M$ & 0,7 & $-0,6$ & 75,4 & 74,7 & 40,6 & 39,9 \\
\hline 33- R.Z. & 33 & 1 & $M$ & $-1,3$ & 0 & 78 & 76,6 & 42,9 & 39,1 \\
\hline 34- R.S. & 34 & 1 & $\mathrm{M}$ & $-0,2$ & $-0,3$ & 81,5 & 79,7 & 43 & 41,6 \\
\hline 35- R.C.M. & 35 & 1 & $M$ & -1 & 0,4 & 75,1 & 74 & 41,7 & 40,8 \\
\hline 36- R.D.P. & 36 & 1 & $M$ & 0,7 & $-0,2$ & 71,2 & 70,8 & 39 & 38,6 \\
\hline 37- S.F.A. & 37 & 1 & $\mathrm{~F}$ & 1,2 & 0,1 & 77,8 & 75,8 & 44 & 41,6 \\
\hline 38- S.A.P. & 38 & 1 & $\mathrm{~F}$ & $-0,2$ & 0 & 78,5 & 76,7 & 45,2 & 42,3 \\
\hline 39- T.L.D. & 39 & 1 & $\mathrm{M}$ & 0,5 & $-0,2$ & 85,2 & 84,1 & 45 & 44,3 \\
\hline 40- V.R.R.F. & 40 & 1 & $\mathrm{~F}$ & $-0,3$ & $-0,7$ & 84,9 & 82,6 & 41,9 & 39,9 \\
\hline 41- W.M.S. & 41 & 1 & $\mathrm{~F}$ & 1,4 & 1,5 & 75,7 & 74,9 & 41,9 & 36,7 \\
\hline 42- W.R.C. & 42 & 1 & $M$ & $-0,4$ & 0,3 & 74,5 & 73 & 39,8 & 42,4 \\
\hline
\end{tabular}


TABELA A-4

\begin{tabular}{|c|c|c|c|c|c|}
\hline Paciente & ZyD-GoD & ZyE-GoE & ZyDMe/ZyEMe & GoDMe/GoEMe & ZyDGoD/ZyEGoE \\
\hline 1- A.B. & 38,8 & 40,2 & 99,5 & 104 & 96,4 \\
\hline 2-A.E. & 35 & 32,3 & 104,1 & 102,8 & 108,6 \\
\hline 3- A.N.P.M. & 39,9 & 38,6 & 103,8 & 107,7 & 103,4 \\
\hline 4- A.L.G.S. & 41,8 & 42 & 100,8 & 103,4 & 99,6 \\
\hline 5- A.P.F.R. & 40,2 & 40,6 & 99 & 98,7 & 99,1 \\
\hline 6- A.G. & 41,8 & 42,7 & 99,3 & 104,7 & 97,7 \\
\hline 7- A.C.M.Jr. & 38,4 & 38,5 & 100,2 & 102,4 & 99,6 \\
\hline 8- B.P.L. & 40,8 & 39,4 & 102,2 & 100,8 & 103,7 \\
\hline 9- B.L.M.E. & 49,8 & 50 & 101 & 102,7 & 99,5 \\
\hline 10- C.Q. & 34,2 & 33,4 & 100,9 & 101,7 & 102,5 \\
\hline 11- C.B.S. & 35,7 & 36,4 & 97,2 & 98 & 97,9 \\
\hline 12- C.A.A. & 37,7 & 39,4 & 98,2 & 101,6 & 95,8 \\
\hline 13- D.F.R.S. & 36,9 & 36,4 & 99,5 & 98,6 & 101,5 \\
\hline 14- D.M.B. & 43,8 & 43,3 & 101,3 & 103,8 & 101,3 \\
\hline 15- D.M.R. & 41,1 & 40,4 & 101,2 & 100,2 & 101,7 \\
\hline 16- E.Y.Y. & 45,5 & 42 & 100,9 & 91,2 & 108,3 \\
\hline 17- E.P. & 42,3 & 43,1 & 99,9 & 103,8 & 98,1 \\
\hline 18- E.A.S. & 48 & 48,5 & 98,1 & 96,1 & 99 \\
\hline 19- F.S.S. & 40,1 & 39,4 & 100 & 97,3 & 101,9 \\
\hline 20- G.N.T. & 44,5 & 44,8 & 101,4 & 105,8 & 99,4 \\
\hline 21- G.F.M.C. & 47,7 & 47,5 & 100,8 & 100,4 & 100,3 \\
\hline 22- I.R.C. & 43,1 & 43,1 & 100,8 & 103,3 & 100 \\
\hline 23- I.A. & 42,1 & 42,9 & 99,4 & 99,2 & 98,2 \\
\hline 24- J.W.M.O. & 44,2 & 44 & 103,1 & 107,9 & 100,4 \\
\hline 25- L.A.S. & 45,3 & 45,7 & 100,2 & 102,3 & 99,2 \\
\hline 26- L.C.M.F. & 42,7 & 41,6 & 100,1 & 98 & 102,8 \\
\hline 27- L.C.S.S. & 39,4 & 39,9 & 97,8 & 96,4 & 98,8 \\
\hline 28- M.A.O.F. & 38,7 & 38,8 & 99,9 & 105,7 & 99,8 \\
\hline 29- M.M.S. & 41,5 & 41,6 & 97,7 & 95,4 & 99,7 \\
\hline 30- N.C.R. & 41,5 & 41,2 & 100,3 & 99,1 & 100,7 \\
\hline 31- P.S.D. & 41,4 & 43,4 & 101,2 & 109,4 & 95,5 \\
\hline 32- R.M.G. & 39,8 & 39,9 & 100,9 & 101,8 & 99,8 \\
\hline 33- R.Z. & 40,6 & 42,2 & 101,9 & 109,6 & 96,1 \\
\hline 34- R.S. & 44,1 & 42,7 & 102,3 & 103,3 & 103,2 \\
\hline 35- R.C.M. & 40,1 & 39,4 & 101,4 & 102,3 & 101,7 \\
\hline 36- R.D.P. & 37,6 & 37,6 & 100,5 & 100,9 & 100 \\
\hline 37- S.F.A. & 39,7 & 40,6 & 102,6 & 105,7 & 97,7 \\
\hline 38- S.A.P. & 40,3 & 40,8 & 102,3 & 106,7 & 98,9 \\
\hline 39- T.L.D. & 45,2 & 44,5 & 101,3 & 101,6 & 101,5 \\
\hline 40- V.R.R.F. & 49,3 & 48,2 & 102,7 & 104,9 & 102,3 \\
\hline 41- W.M.S. & 41,2 & 43,1 & 101 & 114,3 & 95,5 \\
\hline 42- W.R.C. & 40,8 & 37,1 & 102,1 & 93,8 & 109,9 \\
\hline
\end{tabular}


TABELAS A-5 e A-6 - Valores reais individuais de cada variável, para as medidas das fotografias frontais, para cada indivíduo com Classe II, subdivisão do tipo 1 (Grupo 2)

\begin{tabular}{|l|c|c|c|r|r|r|r|r|r|}
\hline \multicolumn{1}{|c|}{ Paciente } & Número & Grupo & Gênero & Me & Sbn & ZyD-Me & ZyE-Me & GoD-Me & GoE-Me \\
\hline 1-A.B. & 1 & 2 & $\mathrm{M}$ & 1 & 1,2 & 70,3 & 70,6 & 37,2 & 35,8 \\
\hline 2-A.E. & 2 & 2 & $\mathrm{~F}$ & 0,3 & $-0,4$ & 63,3 & 60,9 & 35,5 & 34,5 \\
\hline 3-A.C.M.Jr. & 3 & 2 & $\mathrm{M}$ & $-0,4$ & 0,2 & 71,2 & 71,1 & 39,4 & 38,5 \\
\hline 4-B.P.L. & 4 & 2 & $\mathrm{~F}$ & $-0,1$ & $-1,6$ & 74,6 & 73,1 & 40,3 & 40 \\
\hline 5-B.E. & 5 & 2 & $\mathrm{~F}$ & 0,7 & $-0,4$ & 86,4 & 85,5 & 41,7 & 40,6 \\
\hline 6-C.Q. & 6 & 2 & $\mathrm{~F}$ & $-0,6$ & $-1,1$ & 67,5 & 66,9 & 39,6 & 38,9 \\
\hline 7-C.B.S. & 7 & 2 & $\mathrm{M}$ & -1 & $-1,9$ & 71 & 73,1 & 41,3 & 42,2 \\
\hline 8-C.A.A. & 8 & 2 & $\mathrm{M}$ & 0,3 & $-0,4$ & 71,5 & 72,8 & 39,9 & 39,3 \\
\hline 9-D.M.B. & 9 & 2 & $\mathrm{~F}$ & -1 & $-0,5$ & 77,7 & 76,7 & 40,4 & 38,9 \\
\hline 10-D.M.R. & 10 & 2 & $\mathrm{~F}$ & 0,5 & $-0,3$ & 77,1 & 76,2 & 43,2 & 43,1 \\
\hline 11-E.P. & 11 & 2 & $\mathrm{~F}$ & 0,1 & $-0,8$ & 74,8 & 74,9 & 38,5 & 37,1 \\
\hline 12-E.A.S. & 12 & 2 & $\mathrm{M}$ & 0 & $-0,7$ & 80,6 & 82,1 & 38 & 39,6 \\
\hline 13-G.N.T. & 13 & 2 & $\mathrm{M}$ & 0,8 & 0,1 & 78,1 & 77,1 & 40,4 & 38,1 \\
\hline 14-G.F.M.C. & 14 & 2 & $\mathrm{~F}$ & 0,8 & 1,2 & 80,6 & 80 & 37,6 & 37,4 \\
\hline 15-I.A. & 15 & 2 & $\mathrm{M}$ & $-1,1$ & 0,1 & 80,3 & 80,8 & 44,7 & 45 \\
\hline 16-J.W.M.O. & 16 & 2 & $\mathrm{M}$ & 1,8 & $-0,4$ & 74,7 & 72,5 & 36,4 & 33,8 \\
\hline 17-L.A.S. & 17 & 2 & $\mathrm{~F}$ & 0,8 & 0,9 & 81,7 & 81,5 & 42,9 & 41,9 \\
\hline 18-L.C.M.F. & 18 & 2 & $\mathrm{M}$ & 0,4 & 0,2 & 73 & 72,9 & 35,5 & 36,3 \\
\hline 19-L.C.C.S. & 19 & 2 & $\mathrm{M}$ & 0 & $-0,5$ & 66,3 & 67,8 & 32,8 & 34 \\
\hline 10-P.S.D. & 20 & 2 & $\mathrm{~F}$ & 1,5 & 1,7 & 77,8 & 76,9 & 43 & 39,3 \\
\hline 21-R.S. & 21 & 2 & $\mathrm{M}$ & $-0,2$ & $-0,3$ & 81,5 & 79,7 & 43 & 41,6 \\
\hline 22-R.D.P. & 22 & 2 & $\mathrm{M}$ & 0,7 & $-0,2$ & 71,2 & 70,8 & 39 & 38,6 \\
\hline 23-T.L.D. & 23 & 2 & $\mathrm{M}$ & 0,5 & $-0,2$ & 85,2 & 84,1 & 45 & 44,3 \\
\hline 24-V.R.R.F. & 24 & 2 & $\mathrm{~F}$ & $-0,3$ & $-0,7$ & 84,9 & 82,6 & 41,9 & 39,9 \\
\hline 25-W.M.S. & 25 & 2 & $\mathrm{~F}$ & 1,4 & 1,5 & 75,7 & 74,9 & 41,9 & 36,7 \\
\hline
\end{tabular}


TABELA A-6

\begin{tabular}{|l|r|r|r|r|r|}
\hline \multicolumn{1}{|c|}{ Paciente } & ZyD-GoD & ZyE-GoE & ZyDMe/ZyEMe & GoDMe/GoEMe & ZyDGoD/ZyEGoE \\
\hline 1-A.B. & 38,8 & 40,2 & 99,5 & 104 & 96,4 \\
\hline 2-A.E. & 35 & 32,3 & 104,1 & 102,8 & 108,6 \\
\hline 3-A.C.M.Jr. & 38,4 & 38,5 & 100,2 & 102,4 & 99,6 \\
\hline 4-B.P.L. & 40,8 & 39,4 & 102,2 & 100,8 & 103,7 \\
\hline 5-B.E. & 49,8 & 50 & 101 & 102,7 & 99,5 \\
\hline 6-C.Q. & 34,2 & 33,4 & 100,9 & 101,7 & 102,5 \\
\hline 7-C.B.S. & 35,7 & 36,4 & 97,2 & 98 & 97,9 \\
\hline 8-C.A.A. & 37,7 & 39,4 & 98,2 & 101,6 & 95,8 \\
\hline 9-D.M.B. & 43,8 & 43,3 & 101,3 & 103,8 & 101,3 \\
\hline 10-D.M.R. & 41,1 & 40,4 & 101,2 & 100,2 & 101,7 \\
\hline 11-E.P. & 42,3 & 43,1 & 99,9 & 103,8 & 98,1 \\
\hline 12-E.A.S. & 48 & 48,5 & 98,1 & 96,1 & 99 \\
\hline 13-G.N.T. & 44,5 & 44,8 & 101,4 & 105,8 & 99,4 \\
\hline 14-G.F.M.C. & 47,7 & 47,5 & 100,8 & 100,4 & 100,3 \\
\hline 15-I.A. & 42,1 & 42,9 & 99,4 & 99,2 & 98,2 \\
\hline 16-J.W.M.O. & 44,2 & 44 & 103,1 & 107,9 & 100,4 \\
\hline 17-L.A.S. & 45,3 & 45,7 & 100,2 & 102,3 & 99,2 \\
\hline 18-L.C.M.F. & 42,7 & 41,6 & 100,1 & 98 & 102,8 \\
\hline 19-L.C.C.S. & 39,4 & 39,9 & 97,8 & 96,4 & 98,8 \\
\hline 10-P.S.D. & 41,4 & 43,4 & 101,2 & 109,4 & 95,5 \\
\hline 21-R.S. & 44,1 & 42,7 & 102,3 & 103,3 & 103,2 \\
\hline 22-R.D.P. & 37,6 & 37,6 & 100,5 & 100,9 & 100 \\
\hline 23-T.L.D. & 45,2 & 44,5 & 101,3 & 101,6 & 101,5 \\
\hline 24-V.R.R.F. & 49,3 & 48,2 & 102,7 & 104,9 & 102,3 \\
\hline 25-W.M.S. & 41,2 & 43,1 & 101 & 114,3 & 95,5 \\
\hline
\end{tabular}


TABELAS A-7 E A-8 - Valores reais individuais de cada variável, para as medidas das fotografias frontais, para cada indivíduo com Classe II, subdivisão do tipo 2 (Grupo 3)

\begin{tabular}{|l|c|c|c|r|r|r|r|r|r|}
\hline Paciente & Número & Grupo & Gênero & Me & Sbn & ZyD-Me & ZyE-Me & GoD-Me & GoE-Me \\
\hline 1-A.L.G.S. & 1 & 3 & $\mathrm{~F}$ & 0,9 & $-0,7$ & 78,5 & 77,9 & 44,8 & 43,3 \\
\hline 2-A.P.F.R. & 2 & 3 & $\mathrm{~F}$ & 1,2 & 0,3 & 72,8 & 73,6 & 39 & 39,5 \\
\hline 3-D.F.R.S. & 3 & 3 & $\mathrm{M}$ & 0,2 & 0,7 & 72,4 & 72,7 & 43 & 43,6 \\
\hline 4-I.R.C. & 4 & 3 & $\mathrm{~F}$ & $-0,4$ & $-0,2$ & 77,5 & 76,8 & 39,9 & 38,7 \\
\hline 5-M.A.O.F. & 5 & 3 & $\mathrm{M}$ & -1 & 0,4 & 70,1 & 70,2 & 39,9 & 37,8 \\
\hline 6-N.C.R. & 6 & 3 & $\mathrm{~F}$ & 1 & 0,5 & 77,2 & 77 & 42,2 & 42,6 \\
\hline 7-R.Z. & 7 & 3 & $\mathrm{M}$ & $-1,3$ & 0 & 78 & 76,6 & 42,9 & 39,1 \\
\hline 8-R.C.M. & 8 & 3 & $\mathrm{M}$ & -1 & 0,4 & 75,1 & 74 & 41,7 & 40,8 \\
\hline
\end{tabular}

TABELA A-8

\begin{tabular}{|l|r|r|r|r|r|}
\hline \multicolumn{1}{|c|}{ Paciente } & \multicolumn{1}{|c|}{ ZyD-GoD } & \multicolumn{1}{l}{ ZyE-GoE } & ZyDMe/ZyEMe & GoDMe/GoEMe & ZyDGoD/ZyEGoE \\
\hline 1-A.L.G.S. & 41,8 & 42 & 100,8 & 103,4 & 99,6 \\
\hline 2-A.P.F.R. & 40,2 & 40,6 & 99 & 98,7 & 99,1 \\
\hline 3-D.F.R.S. & 36,9 & 36,4 & 99,5 & 98,6 & 101,5 \\
\hline 4-I.R.C. & 43,1 & 43,1 & 100,8 & 103,3 & 100 \\
\hline 5-M.A.O.F. & 38,7 & 38,8 & 99,9 & 105,7 & 99,8 \\
\hline 6-N.C.R. & 41,5 & 41,2 & 100,3 & 99,1 & 100,7 \\
\hline 7-R.Z. & 40,6 & 42,2 & 101,9 & 109,6 & 96,1 \\
\hline 8-R.C.M. & 40,1 & 39,4 & 101,4 & 102,3 & 101,7 \\
\hline
\end{tabular}


TABELAS A-9 a A18 - Valores reais individuais de cada variável, para as medidas das radiografias, para cada indivíduo com Classe II, subdivisão. Os dados apresentados são somente de 14 novos pacientes, os dados dos outros 30 indivíduos com Classe II, subdivisão e com oclusão normal utilizados estão apresentados na tese de JANSON $^{55}$

\begin{tabular}{|l|r|r|r|r|r|r|r|r|r|}
\hline Paciente & Número & Grupo & Gênero & GO-ETC & PPC-ETC & PDMI-ETC & PDMS-ETC & GO-EIC & PPC-EIC \\
\hline 1-B.L.M.E. & 1 & 1 & $\mathrm{~F}$ & -2.6 & -1.3 & 1.6 & -1.2 & 4.5 & 4.5 \\
\hline 2-E.A.S. & 2 & 1 & $\mathrm{M}$ & 2.3 & -1.4 & 1.4 & -3.4 & -1.9 & -1.6 \\
\hline 3-G.N.T. & 3 & 1 & $\mathrm{M}$ & 5.2 & 2.7 & 5.8 & 0.6 & -2.1 & -0.1 \\
\hline 4-G.F.M.C. & 4 & 1 & $\mathrm{~F}$ & -2.8 & 1.2 & 2.6 & -1.9 & -4.0 & 1.8 \\
\hline 5-I.R.C. & 5 & 1 & $\mathrm{~F}$ & 2.6 & -0.3 & 1.7 & -2.3 & -1.2 & 0.9 \\
\hline 6-J.W.M.O. & 6 & 1 & $\mathrm{M}$ & 1.4 & 0.0 & 1.9 & -3.1 & 0.7 & 0.8 \\
\hline 7-L.A.S. & 7 & 1 & $\mathrm{~F}$ & 3.4 & 2.7 & 3.1 & 1.5 & 8.5 & 1.3 \\
\hline 8-L.C.M.F. & 8 & 1 & $\mathrm{M}$ & -2.4 & 0.3 & 3.5 & -1.3 & -1.6 & 3.0 \\
\hline 9-M.A.O. & 9 & 1 & $\mathrm{~F}$ & 1.8 & -1.9 & 4.3 & -0.9 & -0.4 & 7.5 \\
\hline 10-R.Z. & 10 & 1 & $\mathrm{M}$ & 1.1 & 1.0 & 4.6 & 0.1 & -0.8 & -3.4 \\
\hline 11-R.S. & 11 & 1 & $\mathrm{M}$ & 0.9 & -1.6 & 4.2 & -2.4 & -0.5 & -0.9 \\
\hline 12-T.L.D. & 12 & 1 & $\mathrm{M}$ & 0.8 & 0.7 & 1.3 & -0.5 & -0.5 & -3.1 \\
\hline 13-V.R.R.F. & 13 & 1 & $\mathrm{~F}$ & 1.2 & 3.6 & 3.6 & 0.0 & 2.6 & -1.9 \\
\hline 14-W.M.S. & 14 & 1 & $\mathrm{~F}$ & 3.6 & 0.1 & 3.7 & 1.1 & 2.5 & -0.3 \\
\hline
\end{tabular}

TABELA A-10

\begin{tabular}{|l|r|r|r|r|r|r|r|r|}
\hline Paciente & PDMI-EIC & PDMS-EIC & LMM-EIC & LMDI-EIC & LMDS -EIC & PCM-ETE & GO-ETE & PPC-ETE \\
\hline 1-B.L.M.E. & 7.0 & 6.9 & 3.6 & 1.5 & 4.4 & -0.2 & -2.4 & -1.1 \\
\hline 2-E.A.S. & -4.4 & -2.2 & -2.8 & -3.6 & 0.1 & -0.3 & 2.5 & -1.2 \\
\hline 3-G.N.T. & -2.1 & -1.6 & -0.8 & -3.1 & 0.0 & 0.8 & 4.4 & 2.0 \\
\hline 4-G.F.M.C. & 0.5 & 2.0 & 0.2 & 0.1 & 2.4 & -0.4 & -2.3 & 1.6 \\
\hline 5-I.R.C. & 2.7 & 3.8 & 0.8 & -0.9 & 2.0 & -3.1 & 5.4 & 2.5 \\
\hline 6-J.W.M.O. & -1.6 & 0.2 & -0.9 & -1.1 & 1.0 & -2.1 & 3.4 & 2.0 \\
\hline 7-L.A.S. & 0.0 & -1.2 & -0.1 & -1.8 & -0.8 & 0.3 & 3.2 & 2.5 \\
\hline 8-L.C.M.F. & 3.6 & 5.5 & 3.8 & 0.9 & 4.0 & -0.9 & -1.6 & 1.1 \\
\hline 9-M.A.O. & 2.1 & 4.5 & -4.6 & -0.5 & 2.6 & -1.9 & 3.6 & 0.6 \\
\hline 10-R.Z. & -5.9 & -9.0 & -6.4 & -6.5 & -4.4 & -1.1 & 2.2 & 2.1 \\
\hline 11-R.S. & -5.7 & -1.3 & -2.7 & -3.6 & 0.0 & 0.9 & 0.0 & -2.4 \\
\hline 12-T.L.D. & -0.1 & 4.8 & 1.9 & -1.0 & 1.9 & -2.2 & 2.7 & 2.7 \\
\hline 13-V.R.R.F. & -5.3 & -3.2 & -3.2 & -3.6 & -1.4 & -2.0 & 2.9 & 5.2 \\
\hline 14-W.M.S. & 1.5 & -0.5 & 1.3 & -2.9 & 0.0 & 1.6 & 2.1 & -1.4 \\
\hline
\end{tabular}


TABELA A-11

\begin{tabular}{|l|r|r|r|r|r|r|r|r|}
\hline Paciente & PDMI-ETE & PDMS-ETE & PCM-EIE & GO-EIE & PPC-EIE & PDMI-EIE & PDMS-EIE & LMM-EIE \\
\hline 1-B.L.M.E. & 1.7 & -1.1 & -0.4 & 3.9 & 3.6 & 6.1 & 6.0 & 3.0 \\
\hline 2-E.A.S. & 1.5 & -3.3 & -0.1 & -2.3 & -2.1 & -4.9 & -2.7 & -3.1 \\
\hline 3-G.N.T. & 5.4 & 0.2 & 0.3 & -2.3 & 0.0 & -2.0 & -1.5 & -0.6 \\
\hline 4-G.F.M.C. & 2.8 & -1.7 & 3.0 & -1.5 & 4.1 & 2.6 & 4.1 & 1.1 \\
\hline 5-I.R.C. & 3.2 & -0.8 & 0.6 & -1.3 & 0.1 & 1.6 & 2.7 & -0.1 \\
\hline 6-J.W.M.O. & 2.9 & -2.0 & 1.4 & 1.7 & 0.6 & -2.3 & -0.5 & -1.8 \\
\hline 7-L.A.S. & 2.9 & 1.4 & 0.7 & 9.5 & 3.1 & 2.3 & 1.0 & 1.5 \\
\hline 8-L.C.M.F. & 3.9 & -0.8 & 1.4 & -0.5 & 2.7 & 3.0 & 4.8 & 2.9 \\
\hline 9-M.A.O. & 5.3 & 0.1 & -4.0 & -4.1 & 2.3 & -3.4 & -1.0 & -7.9 \\
\hline 10-R.Z. & 5.2 & 0.7 & 0.5 & -1.3 & -5.1 & -8.3 & -11.4 & -8.1 \\
\hline 11-R.S. & 3.7 & -2.9 & 3.5 & 3.6 & 3.9 & -0.7 & 3.7 & 0.1 \\
\hline 12-T.L.D. & 2.5 & 0.6 & -0.6 & 0.6 & -3.8 & -1.4 & 3.5 & 0.6 \\
\hline 13-V.R.R.F. & 4.5 & 0.9 & -0.1 & 2.4 & -3.6 & -7.4 & -5.4 & -4.9 \\
\hline 14-W.M.S. & 2.8 & 0.2 & 0.5 & 3.0 & 1.9 & 4.0 & 2.2 & 3.4 \\
\hline
\end{tabular}

TABELA A-12

\begin{tabular}{|l|r|r|r|r|r|r|r|}
\hline Paciente & LMDI-EIE & LMDS -EIE & VA-EIPTM & VP-EIPTM & LMDS -EIPTM & LMM-EIPTM & LMDI-EIPTM \\
\hline 1-B.L.M.E. & 0.9 & 3.9 & -0.3 & -1.0 & 2.7 & 1.9 & -0.3 \\
\hline 2-E.A.S. & -3.9 & -0.2 & -2.1 & -0.1 & -4.2 & -6.3 & -7.4 \\
\hline 3-G.N.T. & -3.0 & 0.2 & 1.4 & -0.6 & -1.0 & -1.7 & -4.1 \\
\hline 4-G.F.M.C. & 1.0 & 3.3 & 4.5 & 0.1 & 1.3 & -0.9 & -1.0 \\
\hline 5-I.R.C. & -1.9 & 1.0 & 1.8 & 0.0 & 3.7 & 2.3 & 0.6 \\
\hline 6-J.W.M.O. & -2.1 & -0.2 & -0.3 & 1.1 & 0.1 & -1.6 & -1.9 \\
\hline 7-L.A.S. & -0.3 & 0.8 & 1.5 & 0.5 & 3.3 & 3.9 & 2.1 \\
\hline 8-L.C.M.F. & 0.0 & 3.0 & 1.0 & 2.1 & -0.3 & 0.0 & -3.0 \\
\hline 9-M.A.O. & -3.9 & -0.9 & 1.3 & 0.2 & -2.2 & -9.1 & -5.1 \\
\hline 10-R.Z. & -8.2 & -6.2 & 0.8 & 1.2 & -2.7 & -4.7 & -4.8 \\
\hline 11-R.S. & -0.8 & 3.0 & -1.4 & -0.2 & -4.1 & -5.6 & -7.3 \\
\hline 12-T.L.D. & -2.6 & 0.3 & 0.5 & 1.1 & 3.5 & 3.5 & 0.6 \\
\hline 13-V.R.R.F. & -5.4 & -3.4 & 0.7 & 0.9 & 0.6 & -1.4 & -1.7 \\
\hline 14-W.M.S. & -0.7 & 2.5 & 1.9 & 0.1 & 2.1 & 2.9 & -1.2 \\
\hline
\end{tabular}


TABELA A-13

\begin{tabular}{|l|r|r|r|r|r|r|r|}
\hline Paciente & LMDI-EIMI & LMM-EIMI & LMDS -EIMI & LMDI-EIMS & LMDS-EIMS & LMM-EIMS & EIE-EIC \\
\hline 1-B.L.M.E. & -0.7 & 1.3 & 2.3 & -3.1 & -0.3 & -1.0 & 0.1 \\
\hline 2-E.A.S. & -0.1 & 0.6 & 3.8 & -4.4 & -1.0 & -3.4 & 0.1 \\
\hline 3-G.N.T. & 3.0 & 4.5 & 6.7 & -1.5 & 1.7 & 0.7 & -0.1 \\
\hline 4-G.F.M.C. & 1.9 & 2.2 & 4.5 & -2.3 & -0.3 & -2.4 & 0.3 \\
\hline 5-I.R.C. & -1.2 & 0.5 & 1.9 & -4.4 & -1.6 & -2.5 & 0.6 \\
\hline 6-J.W.M.O. & 1.2 & 1.2 & 3.5 & -3.7 & -1.9 & -3.0 & 1.0 \\
\hline 7-L.A.S. & 1.0 & 2.8 & 2.3 & 0.6 & 1.8 & 2.4 & -0.7 \\
\hline 8-L.C.M.F. & 2.0 & 4.6 & 5.3 & -2.4 & 0.6 & 0.5 & 1.0 \\
\hline 9-M.A.O. & 1.1 & -3.1 & 4.4 & -3.6 & -0.6 & -7.6 & 1.0 \\
\hline 10-R.Z. & -0.2 & -0.3 & 2.1 & -1.4 & 0.7 & -1.3 & 0.9 \\
\hline 11-R.S. & 3.1 & 3.0 & 7.6 & -4.2 & -0.9 & -2.9 & -0.5 \\
\hline 12-T.L.D. & 0.0 & 2.7 & 3.0 & -4.0 & -1.1 & -0.9 & 1.3 \\
\hline 13-V.R.R.F. & 2.1 & 2.2 & 4.9 & -1.6 & 0.6 & -1.2 & 1.1 \\
\hline 14-W.M.S. & -0.5 & 3.4 & 3.1 & -2.2 & 0.8 & 2.0 & -1.4 \\
\hline
\end{tabular}

TABELA A-14

\begin{tabular}{|l|r|r|r|r|r|r|r|}
\hline Paciente & ETE-ETC & ETMFETE & ETMLETC & ETMS-ETE & ETMS-ETC & PCM-LMM & PCM-CMM \\
\hline 1-B.L.M.E. & 0.1 & -1.9 & -1.7 & 1.2 & 1.3 & -3.1 & -3.6 \\
\hline 2-E.A.S. & 0.2 & -1.6 & -1.5 & 3.4 & 3.6 & 2.7 & 5.8 \\
\hline 3-G.N.T. & -0.4 & -5.4 & -5.8 & -0.2 & -0.6 & 1.0 & 0.7 \\
\hline 4-G.F.M.C. & 0.2 & -3.0 & -2.8 & 1.9 & 2.1 & -0.4 & 0.8 \\
\hline 5-I.R.C. & 1.7 & -3.5 & -1.8 & 0.9 & 2.6 & -1.0 & -1.2 \\
\hline 6-J.W.M.O. & 1.2 & -3.3 & -2.1 & 2.2 & 3.3 & 1.1 & 4.3 \\
\hline 7-L.A.S. & -0.1 & -3.5 & -3.6 & -1.5 & -1.7 & -0.2 & -0.5 \\
\hline 8-L.C.M.F. & 0.5 & -4.1 & -3.6 & 0.8 & 1.3 & -3.7 & -0.3 \\
\hline 9-M.A.O. & 0.9 & -5.1 & -4.2 & -0.1 & 0.8 & 4.9 & 0.4 \\
\hline 10-R.Z. & 0.6 & -5.4 & -4.8 & -0.7 & -0.1 & 6.5 & 0.9 \\
\hline 11-R.S. & -0.5 & -3.9 & -4.4 & 3.2 & 2.6 & 2.2 & 3.6 \\
\hline 12-T.L.D. & 1.2 & -2.5 & -1.3 & -0.6 & 0.5 & -4.0 & -2.7 \\
\hline 13-V.R.R.F. & 1.1 & -5.6 & -4.5 & -1.0 & 0.1 & 3.1 & 3.5 \\
\hline 14-W.M.S. & -0.9 & -2.8 & -3.7 & -0.2 & -1.1 & -2.0 & 1.5 \\
\hline
\end{tabular}


TABELA A-15

\begin{tabular}{|l|r|r|r|r|r|r|r|r|}
\hline Paciente & POSM & POSMS & ÂPLANOZ & ÂPLOCLUSAL & ÂPLANTEG & DESMAND & A1 & B1 \\
\hline 1-B.L.M.E. & 2.7 & 5.1 & 91.0 & 92.3 & 92.7 & -0.1 & -0.6 & 2.0 \\
\hline 2-E.A.S. & 0.6 & 1.6 & 91.0 & 92.4 & 90.6 & -1.5 & -2.2 & 1.5 \\
\hline 3-G.N.T. & -3.3 & -0.8 & 90.2 & 92.5 & 91.4 & 0.5 & -0.9 & 2.1 \\
\hline 4-G.F.M.C. & -3.3 & -2.1 & 90.4 & 89.5 & 90.6 & 2.4 & 0.6 & 2.2 \\
\hline 5-I.R.C. & 0.9 & 1.9 & 89.6 & 89.9 & 90.2 & 3.0 & -1.9 & 1.5 \\
\hline 6-J.W.M.O. & 1.5 & 3.3 & 89.9 & 90.9 & 88.9 & 4.2 & -0.5 & 2.2 \\
\hline 7-L.A.S. & 1.4 & 3.3 & 90.9 & 89.7 & 90.2 & 0.7 & 0.0 & 1.4 \\
\hline 8-L.C.M.F. & -2.1 & 0.4 & 89.0 & 88.6 & 90.2 & 2.2 & -0.2 & 2.5 \\
\hline 9-M.A.O. & -2.4 & -1.4 & 92.7 & 88.2 & 89.2 & 4.0 & -0.7 & 1.5 \\
\hline 10-R.Z. & -2.5 & -0.3 & 89.6 & 91.2 & 91.1 & 0.6 & 0.4 & 1.6 \\
\hline 11-R.S. & -1.9 & -0.6 & 90.2 & 89.1 & 83.6 & 3.0 & -0.2 & 3.8 \\
\hline 12-T.L.D. & -0.9 & -1.5 & 89.5 & 89.9 & 90.3 & 1.8 & -0.2 & 3.1 \\
\hline 13-V.R.R.F. & -0.1 & 0.4 & 89.4 & 90.7 & 88.0 & 4.4 & 0.0 & 2.2 \\
\hline 14-W.M.S. & -0.2 & -0.4 & 90.5 & 91.5 & 90.7 & 1.4 & -1.1 & 1.3 \\
\hline
\end{tabular}

TABELA A-16

\begin{tabular}{|l|r|r|r|r|r|r|r|}
\hline \multicolumn{1}{|c|}{ Paciente } & \multicolumn{1}{c|}{ ÂANT } & \multicolumn{1}{c|}{ DISTZ } & \multicolumn{1}{c|}{ DISTCO } & \multicolumn{1}{c|}{ DISTZA } & \multicolumn{1}{c|}{ DISTNC } & \multicolumn{1}{c|}{ DISTJ } & \multicolumn{1}{c|}{ DISTAG } \\
\hline 1-B.L.M.E. & -1.0 & -2.0 & -11.6 & -10.1 & -5.7 & -5.3 & -5.4 \\
\hline 2-E.A.S. & 0.6 & -2.7 & 2.8 & 2.6 & -0.5 & -0.9 & 0.6 \\
\hline 3-G.N.T. & 0.4 & -0.6 & 2.4 & 2.3 & 0.2 & 1.2 & 1.3 \\
\hline 4-G.F.M.C. & -2.3 & -1.3 & -5.4 & -8.4 & -1.7 & -3.7 & -5.1 \\
\hline 5-I.R.C. & -3.9 & 0.7 & 1.3 & -0.4 & 1.2 & 1.1 & 1.8 \\
\hline 6-J.W.M.O. & -4.5 & 1.0 & 0.7 & 0.1 & 1.2 & 0.3 & -1.6 \\
\hline 7-L.A.S. & -5.7 & -1.0 & 0.3 & -0.4 & -0.2 & -2.7 & 1.1 \\
\hline 8-L.C.M.F. & -1.8 & 2.5 & -4.4 & -2.3 & 0.9 & 3.1 & -1.3 \\
\hline 9-M.A.O. & -9.2 & -3.2 & -8.5 & -8.9 & -6.7 & -7.4 & -10.1 \\
\hline 10-R.Z. & 2.5 & -1.0 & 7.9 & 2.4 & 0.9 & 0.9 & 3.6 \\
\hline 11-R.S. & -7.2 & -1.2 & -0.5 & -2.6 & -0.8 & -1.1 & -2.3 \\
\hline 12-T.L.D. & -0.1 & 0.5 & -4.1 & -5.2 & 0.4 & -0.7 & -2.2 \\
\hline 13-V.R.R.F. & -6.9 & 4.9 & -12.4 & -10.0 & 2.2 & -2.3 & -6.6 \\
\hline 14-W.M.S. & -9.1 & -0.6 & -1.2 & -8.0 & -0.3 & -1.7 & 2.6 \\
\hline
\end{tabular}


TABELA A-17

\begin{tabular}{|l|r|r|r|r|r|r|r|}
\hline \multicolumn{1}{|c|}{ Paciente } & \multicolumn{1}{c|}{ ALT6 } & CO-AG & CO-ME & ME-AG & DESVENA & PDMI-ETPTM & PDMS-ETPTM \\
\hline 1-B.L.M.E. & -3.1 & -8.2 & -7.5 & 0.9 & 1.4 & 1.5 & -1.3 \\
\hline 2-E.A.S. & -0.3 & 2.8 & 3.3 & 0.4 & 0.8 & 5.9 & 1.2 \\
\hline 3-G.N.T. & -1.2 & -4.3 & 0.3 & 4.7 & 0.6 & 5.6 & 0.4 \\
\hline 4-G.F.M.C. & -6.5 & -2.1 & -0.7 & 2.5 & 1.0 & 2.5 & -2.0 \\
\hline 5-I.R.C. & -2.2 & -0.5 & 3.3 & 6.0 & -0.3 & 0.0 & -4.0 \\
\hline 6-J.W.M.O. & 0.2 & 0.8 & 3.6 & 5.1 & 0.1 & 2.2 & -2.8 \\
\hline 7-L.A.S. & 3.9 & 1.2 & 2.9 & 4.8 & 1.1 & 0.6 & -1.1 \\
\hline 8-L.C.M.F. & 0.5 & -4.5 & -3.6 & 1.5 & -0.6 & 7.5 & 2.9 \\
\hline 9-M.A.O. & 0.0 & 1.8 & 2.2 & 4.5 & 2.9 & 5.6 & 0.4 \\
\hline 10-R.Z. & -2.7 & -0.8 & 4.3 & 4.5 & -0.2 & 4.0 & -0.6 \\
\hline 11-R.S. & -2.3 & 8.6 & 0.8 & -5.1 & -0.1 & 7.2 & 0.4 \\
\hline 12-T.L.D. & -2.1 & -1.2 & -0.9 & 0.3 & -0.6 & 1.0 & -0.8 \\
\hline 13-V.R.R.F. & -4.3 & 1.1 & -2.8 & -1.5 & -0.6 & 2.6 & -1.0 \\
\hline 14-W.M.S. & -3.2 & -2.8 & 0.2 & 7.5 & 1.0 & 2.2 & -0.3 \\
\hline
\end{tabular}

\section{TABELA A-18}

\begin{tabular}{|l|r|r|r|r|r|r|}
\hline Paciente & PDMI-EIPTM & PDMS-EIPTM & ETPTM-ETC & ETPTM -ETE & ETMI-ETPTM & ETMS-ETPTM \\
\hline 1-B.L.M.E. & 3.8 & 3.7 & -0.1 & -0.3 & -1.6 & 1.4 \\
\hline 2-E.A.S. & -5.6 & -3.6 & 4.8 & 4.7 & -6.3 & -1.3 \\
\hline 3-G.N.T. & -3.3 & -2.8 & -0.2 & 0.2 & -5.5 & -0.4 \\
\hline 4-G.F.M.C. & -1.7 & -0.2 & 0.0 & -0.3 & -2.8 & 2.2 \\
\hline 5-I.R.C. & 3.0 & 4.2 & -1.8 & -3.5 & 0.0 & 4.4 \\
\hline 6-J.W.M.O. & -2.5 & -0.8 & 0.4 & -0.8 & -2.5 & 3.0 \\
\hline 7-L.A.S. & 4.1 & 2.9 & -2.9 & -2.8 & -0.7 & 1.2 \\
\hline 8-L.C.M.F. & 0.2 & 2.0 & 4.3 & 3.8 & -7.9 & -3.0 \\
\hline 9-M.A.O. & -5.2 & -2.8 & 1.2 & 0.3 & -5.4 & -0.3 \\
\hline 10-R.Z. & -2.8 & -6.0 & -0.6 & -1.2 & -4.1 & 0.6 \\
\hline 11-R.S. & -8.3 & -4.1 & 3.1 & 3.6 & -7.5 & -0.5 \\
\hline 12-T.L.D. & 3.4 & 8.3 & -0.4 & -1.5 & -1.0 & 0.9 \\
\hline 13-V.R.R.F. & -2.8 & -0.7 & -1.2 & -2.3 & -3.3 & 1.3 \\
\hline 14-W.M.S. & 1.4 & -0.2 & -1.5 & -0.5 & -2.2 & 0.3 \\
\hline
\end{tabular}


TABELA A-19 e A20 - Valores reais obtidos da $2^{\mathrm{a}}$ medição da fotografia frontal, de 10 indivíduos selecionados aleatoriamente, para a avaliação dos erros casuais e sistemáticos

\begin{tabular}{|l|c|r|r|r|r|r|r|r|}
\hline \multicolumn{1}{|c|}{ Nome } & Gênero & Idade & Me & Sub & \multicolumn{1}{|c|}{ ZyD-Me } & ZyE-Me & GoD-Me & \multicolumn{1}{c|}{ GoE-Me } \\
\hline 1-A.L.G.S. & $\mathrm{F}$ & 12,12 & 0,7 & $-0,1$ & 78,2 & 77,8 & 43,4 & 43,4 \\
\hline 2-B.L.M.E. & $\mathrm{F}$ & 15,75 & 0,6 & $-0,8$ & 85,6 & 85,1 & 41,3 & 40,7 \\
\hline 3-D.F.R.S. & $\mathrm{M}$ & 16,79 & $-0,3$ & 1,2 & 72,9 & 73,6 & 42,2 & 45 \\
\hline 4-D.M.B. & $\mathrm{F}$ & 19,46 & 0,4 & 0,6 & 78 & 76,9 & 40,3 & 40,2 \\
\hline 5-E.Y.Y. & $\mathrm{M}$ & 13,17 & $-0,5$ & $-1,6$ & 81,1 & 79,1 & 41,8 & 44,5 \\
\hline 6-E.P. & $\mathrm{F}$ & 15,09 & 0,5 & $-0,6$ & 75 & 75,4 & 37,5 & 38,3 \\
\hline 7-F.S.S. & $\mathrm{M}$ & 12,91 & $-0,4$ & 0 & 74,5 & 75,9 & 40,7 & 41,4 \\
\hline 8-I.R.C. & $\mathrm{F}$ & 14,75 & $-0,1$ & $-0,2$ & 77,9 & 77,2 & 39,5 & 38,2 \\
\hline 9-J.W.M.O. & $\mathrm{M}$ & 12,33 & 0,5 & $-0,8$ & 74,5 & 73,5 & 35,4 & 35 \\
\hline 10-P.S.D. & $\mathrm{F}$ & 15,16 & 0,8 & 1,7 & 77,8 & 76,8 & 43,4 & 39,3 \\
\hline
\end{tabular}

\section{TABELA A-20}

\begin{tabular}{|l|r|r|r|r|r|}
\hline \multicolumn{1}{|c|}{ Nome } & ZyD-GoD & ZyE-GoE & ZyDMe/ZyEMe & GoDMe/GoEMe & ZyDGoD/ZyEGoE \\
\hline 1-A.L.G.S. & 42,7 & 41,8 & 100,6 & 100,1 & 102,2 \\
\hline 2-B.L.M.E. & 49,9 & 49,7 & 100,5 & 101,3 & 100,3 \\
\hline 3-D.F.R.S. & 38,1 & 36,5 & 99,1 & 93,8 & 104,5 \\
\hline 4-D.M.B. & 44,1 & 42 & 101,4 & 100,3 & 105,1 \\
\hline 5-E.Y.Y. & 45,4 & 41,5 & 102,4 & 93,9 & 109,4 \\
\hline 6-E.P. & 43,3 & 42,2 & 99,4 & 98,1 & 102,5 \\
\hline 7-F.S.S. & 38,9 & 40,4 & 98,2 & 98,2 & 96,2 \\
\hline 8-I.R.C. & 44 & 43,6 & 100,8 & 103,6 & 100,9 \\
\hline 9-J.W.M.O. & 44,7 & 44,2 & 101,4 & 101 & 101,2 \\
\hline 10-P.S.D. & 40,8 & 43,4 & 101,3 & 110,3 & 94,1 \\
\hline
\end{tabular}


TABELA A-21 a $\mathbf{A 2 2}$ - Valores obtidos do $2^{\circ}$ traçado das radiografias, de 10 indivíduos selecionados aleatoriamente, para a avaliação dos erros casuais e sistemáticos

\begin{tabular}{|l|c|r|r|r|r|r|r|r|}
\hline \multicolumn{1}{|c|}{ Nome } & Sexo & Idade & GO-ETC & PPC-ETC & PDMI-ETC & PDMS-ETC & GO-EIC & PPC-EIC \\
\hline 1-B.L.M.E. & F & 15,8 & 1,2 & 0,3 & 1,7 & 2 & 14,4 & 12,6 \\
\hline 2-E.A.S. & M & 13,4 & 3,2 & 0,1 & 2,3 & 2,7 & 1,6 & 1,1 \\
\hline 3-G.N.T. & M & 13,8 & 3,5 & 0,8 & 5,7 & 0,2 & 1,8 & 1,9 \\
\hline 4-G.F.M.C. & $\mathrm{F}$ & 13,6 & 1 & 5,1 & 3,1 & 1,8 & 3,9 & 1,3 \\
\hline 5-I.R.C. & $\mathrm{F}$ & 14,8 & 3,2 & 0,7 & 1,6 & 1,9 & 1,5 & 0,3 \\
\hline 6-J.W.M.O. & $\mathrm{M}$ & 12,3 & 1 & 0,7 & 2,5 & 1,7 & 0,8 & 0,8 \\
\hline 7-L.A.S. & $\mathrm{F}$ & 12,4 & 4,8 & 2,9 & 3,1 & 0,6 & 5,2 & 1,8 \\
\hline 8-M.A.O. & $\mathrm{F}$ & 15,3 & 1,4 & 0,3 & 5 & 0,7 & 0,1 & 6,2 \\
\hline 9-R.S. & $\mathrm{M}$ & 15,2 & 1,1 & 1,4 & 3,6 & 2,3 & 2,6 & 3 \\
\hline 10-W.M.S. & $\mathrm{F}$ & 12,3 & 3,4 & 1,6 & 6,9 & 0,6 & 2,3 & 1,2 \\
\hline
\end{tabular}

TABELA A-22

\begin{tabular}{|l|r|r|r|r|r|r|r|r|}
\hline Nome & PDMI-EIC & PDMS-EIC & LMM-EIC & LMDI-EIC & LMDS -EIC & PCM-ETE & GO-ETE & PPC-ETE \\
\hline 1-B.L.M.E. & 15,5 & 15,7 & 8,4 & 6,3 & 8,4 & 0,2 & 1 & 0,2 \\
\hline 2-E.A.S. & 1,2 & 1,2 & 2,9 & 3,7 & 0,3 & 1 & 2,3 & 0,8 \\
\hline 3-G.N.T. & 0,1 & 0,3 & 0 & 1,9 & 1,3 & 1,5 & 2 & 0,5 \\
\hline 4-G.F.M.C. & 1,5 & 0,9 & 1,3 & 1,4 & 0,5 & 3,1 & 4,1 & 2,5 \\
\hline 5-I.R.C. & 2 & 3,3 & 0,2 & 1,4 & 1,4 & 2,1 & 5 & 2,5 \\
\hline 6-J.W.M.O. & 1,2 & 0,2 & 0,9 & 1,6 & 1,7 & 1,7 & 2,6 & 2,2 \\
\hline 7-L.A.S. & 1,4 & 0,5 & 1,8 & 1,3 & 0,3 & 0,3 & 5,1 & 3,2 \\
\hline 8-M.A.O. & 1,4 & 3,1 & 4,5 & 1,1 & 2 & 0,3 & 1,8 & 0,6 \\
\hline 9-R.S. & 2,4 & 3,9 & 0,1 & 1,1 & 2,8 & 0,1 & 1,1 & 1,4 \\
\hline 10-W.M.S. & 0,3 & 1,6 & 1,5 & 3,3 & 0,5 & 1,9 & 1,6 & 0,2 \\
\hline
\end{tabular}

TABELA A-23

\begin{tabular}{|l|r|r|r|r|r|r|r|r|}
\hline \multicolumn{1}{|c|}{ Nome } & PDMI-ETE & PDMS-ETE & PCM-EIE & GO-EIE & PPC-EIE & PDMI-EIE & PDMS-EIE & LMM-EIE \\
\hline 1-B.L.M.E. & 1,8 & 1,9 & 0,4 & 5,5 & 3,3 & 6 & 6,2 & 3,4 \\
\hline 2-E.A.S. & 1,8 & 3,2 & 0,5 & 2,4 & 1,6 & 1,6 & 1,5 & 2,9 \\
\hline 3-G.N.T. & 4,9 & 0,6 & 0,6 & 2,4 & 1,8 & 0 & 0,2 & 0,3 \\
\hline 4-G.F.M.C. & 1,6 & 3,3 & 1,4 & 2,1 & 2 & 2,4 & 4,8 & 1,6 \\
\hline 5-I.R.C. & 2,6 & 0,9 & 0,1 & 1,5 & 1,8 & 0,3 & 1 & 1,7 \\
\hline 6-J.W.M.O. & 3,4 & 0,9 & 1,1 & 1,9 & 0,6 & 1,8 & 0,4 & 1,8 \\
\hline 7-L.A.S. & 3,2 & 0,7 & 1,5 & 6 & 2,6 & 2,2 & 0,3 & 1,4 \\
\hline 8-M.A.O. & 5,2 & 0,6 & 3,8 & 4,2 & 2,2 & 2,6 & 0,8 & 6,5 \\
\hline 9-R.S. & 3,6 & 2,2 & 1,7 & 4,3 & 3,9 & 1,6 & 4,6 & 0,2 \\
\hline 10-W.M.S. & 5,8 & 1,8 & 0,9 & 3,5 & 1,7 & 3,6 & 5 & 1,1 \\
\hline
\end{tabular}


TABELA A-24

\begin{tabular}{|l|r|r|r|r|r|r|r|}
\hline Nome & LMDI-EIE & LMDS -EIE & VA-EIPTM & VP-EIPTM & LMDS-EIPTM & LMM-EIPTM & LMDI-EIPTM \\
\hline 1-B.L.M.E. & 1,3 & 3,5 & 1,6 & 1,9 & 0,7 & 0,7 & 1,4 \\
\hline 2-E.A.S. & 3,6 & 0,2 & 2,2 & 0,5 & 4,7 & 6,7 & 7,7 \\
\hline 3-G.N.T. & 1,6 & 1,6 & 2,5 & 1,2 & 1,7 & 0,4 & 1,5 \\
\hline 4-G.F.M.C. & 1,4 & 3,4 & 5,7 & 0 & 0,7 & 1,1 & 1,2 \\
\hline 5-I.R.C. & 3,3 & 0,6 & 1 & 1,6 & 0,8 & 0,3 & 1,9 \\
\hline 6-J.W.M.O. & 2,5 & 0,6 & 0,3 & 0,9 & 0,9 & 1,5 & 2,2 \\
\hline 7-L.A.S. & 0,8 & 0,1 & 2,2 & 0,8 & 2,9 & 1,3 & 1,9 \\
\hline 8-M.A.O. & 3 & 0,1 & 0,9 & 0,1 & 2,4 & 8,8 & 5,4 \\
\hline 9-R.S. & 1,1 & 2,7 & 0,8 & 0,1 & 1,8 & 3,4 & 5,3 \\
\hline 10-W.M.S. & 0,7 & 2,4 & 0,6 & 0,1 & 0,1 & 1,3 & 3,1 \\
\hline
\end{tabular}

TABELA A-25

\begin{tabular}{|l|r|r|r|r|r|r|r|}
\hline \multicolumn{1}{|c|}{ Nome } & LMDI-EIMI & LMM-EIMI & LMDS -EIMI & LMDI-EIMS & LMDS-EIMS & LMM-EIMS & EIE-EIC \\
\hline 1-B.L.M.E. & 0,1 & 1,9 & 2,1 & 3,2 & 1,1 & 1 & 0,3 \\
\hline 2-E.A.S. & 1,7 & 1 & 1,9 & 5,1 & 1,9 & 4,1 & 0,3 \\
\hline 3-G.N.T. & 2 & 3,5 & 5,7 & 2,4 & 0,7 & 0,4 & 0,4 \\
\hline 4-G.F.M.C. & 1,7 & 2,1 & 3,9 & 2,6 & 0,8 & 2,6 & 1,3 \\
\hline 5-I.R.C. & 1,4 & 0,1 & 1,5 & 4,2 & 1,5 & 2,5 & 1,3 \\
\hline 6-J.W.M.O. & 0,8 & 1,2 & 4,3 & 2,6 & 0,4 & 1,7 & 1 \\
\hline 7-L.A.S. & 0,5 & 0,1 & 1,7 & 0,2 & 1,2 & 0,4 & 0 \\
\hline 8-M.A.O. & 1,4 & 2,2 & 4,8 & 3,6 & 0,6 & 7 & 0,1 \\
\hline 9-R.S. & 3,1 & 3,4 & 7,4 & 5,4 & 1,8 & 3,6 & 0,5 \\
\hline 10-W.M.S. & 1,5 & 3 & 5,5 & 4,2 & 1,5 & 2,3 & 1,5 \\
\hline
\end{tabular}

TABELA A-26

\begin{tabular}{|l|r|r|r|r|r|r|r|r|}
\hline \multicolumn{1}{|c|}{ Nome } & ETE-ETC & ETMIETE & ETMLETC & ETMS-ETE & ETMS-ETC & PCM-LMM & PCM-CMM & POSM \\
\hline 1-B.L.M.E. & 0,1 & 2 & 1,9 & 2,1 & 2,2 & 3 & 1,1 & 2,1 \\
\hline 2-E.A.S. & 0,5 & 1,9 & 2,5 & 3,3 & 2,8 & 3,9 & 6 & 0,8 \\
\hline 3-G.N.T. & 0,8 & 4,9 & 5,6 & 0,6 & 0,2 & 0 & 0,7 & 1,1 \\
\hline 4-G.F.M.C. & 1,7 & 1,7 & 3,4 & 3,6 & 1,9 & 1 & 4,8 & 2,2 \\
\hline 5-I.R.C. & 1,1 & 2,8 & 1,7 & 1 & 2,1 & 0,1 & 1,4 & 0,9 \\
\hline 6-J.W.M.O. & 0,9 & 3,7 & 2,8 & 0,9 & 1,9 & 1,4 & 3,4 & 1,5 \\
\hline 7-L.A.S. & 0,2 & 3,7 & 3,5 & 0,8 & 0,6 & 0,9 & 0,4 & 1,7 \\
\hline 8-M.A.O. & 0,2 & 4,9 & 4,8 & 0,5 & 0,7 & 4,8 & 0,2 & 2,2 \\
\hline 9-R.S. & 0 & 3,8 & 3,8 & 2,5 & 2,5 & 0,3 & 2 & 0,8 \\
\hline 10-W.M.S. & 1,1 & 5,8 & 7 & 1,7 & 0,6 & 1,5 & 3 & 1,2 \\
\hline
\end{tabular}


TABELA A-27

\begin{tabular}{|l|r|r|r|r|r|r|r|}
\hline \multicolumn{1}{|c|}{ Nome } & POSMS & ÂPLANOZ & APOCLUSAL & ÂPLANTEG & DESMAND & \multicolumn{1}{c|}{ A1 } & B1 \\
\hline 1-B.L.M.E. & 5,3 & 91,5 & 91,9 & 91,9 & 1,6 & 3,5 & 1,6 \\
\hline 2-E.A.S. & 2,8 & 89,3 & 91,6 & 91,5 & 0,9 & 0,5 & 2,1 \\
\hline 3-G.N.T. & 0,2 & 90,6 & 90,6 & 91,4 & 0,9 & 0,8 & 2,2 \\
\hline 4-G.F.M.C. & 1 & 89,7 & 90,3 & 90,8 & 2,8 & 0,7 & 2,1 \\
\hline 5-I.R.C. & 1,7 & 89,9 & 90,5 & 87,5 & 3,3 & 0,6 & 3,5 \\
\hline 6-J.W.M.O. & 3,2 & 91,2 & 91,6 & 93,1 & 0 & 0,2 & 1,5 \\
\hline 7-L.A.S. & 3,7 & 91,6 & 88,5 & 88,5 & 2,9 & 0,5 & 1,5 \\
\hline 8-M.A.O. & 1,4 & 91,9 & 90,6 & 87,3 & 2,1 & 0,6 & 3,1 \\
\hline 9-R.S. & 1,1 & 89,7 & 89,7 & 90,6 & 4,7 & 0,7 & 3,1 \\
\hline 10-W.M.S. & 1,6 & 91,1 & 91 & 89,5 & 1,7 & 0,4 & 1,9 \\
\hline
\end{tabular}

TABELA A-28

\begin{tabular}{|l|r|r|r|r|r|r|r|}
\hline \multicolumn{1}{|c|}{ Nome } & ÂANT & \multicolumn{1}{c|}{ DISTZ } & \multicolumn{1}{c|}{ DISTCO } & \multicolumn{1}{c|}{ DISTZA } & \multicolumn{1}{c|}{ DISTNC } & \multicolumn{1}{c|}{ DISTJ } & \multicolumn{1}{c|}{ DISTAG } \\
\hline 1-B.L.M.E. & 0,1 & 1,1 & 4,4 & 3,9 & 1,5 & 3 & 3,6 \\
\hline 2-E.A.S. & 1,6 & 1,5 & 1,6 & 3,2 & 1,2 & 0,1 & 5 \\
\hline 3-G.N.T. & 1,5 & 3 & 7,9 & 7,3 & 2 & 1,7 & 4,7 \\
\hline 4-G.F.M.C. & 0,1 & 2,1 & 2,2 & 1,4 & 0,7 & 1 & 0,3 \\
\hline 5-I.R.C. & 2,6 & 3,2 & 2,3 & 3 & 2,2 & 1,6 & 1,4 \\
\hline 6-J.W.M.O. & 4,6 & 1,4 & 0,6 & 0,2 & 0 & 2,7 & 3,7 \\
\hline 7-L.A.S. & 9 & 1,6 & 8,3 & 7,4 & 4,9 & 5,5 & 7,3 \\
\hline 8-M.A.O. & 6,7 & 0,1 & 1,5 & 1,5 & 1,6 & 0,4 & 1,5 \\
\hline 9-R.S. & 3,9 & 0,1 & 3,2 & 5,8 & 0,7 & 2,3 & 3,3 \\
\hline 10-W.M.S. & 7,5 & 1,5 & 1,9 & 7,9 & 1,9 & 4,2 & 0,9 \\
\hline
\end{tabular}

TABELA A-29

\begin{tabular}{|l|r|r|r|r|r|r|r|}
\hline \multicolumn{1}{|c|}{ Nome } & ALT6 & CO-AG & CO-ME & ME-AG & DESVENA & PDMI-ETPTM & PDMS-ETPTM \\
\hline 1-B.L.M.E. & 3,6 & 0,4 & 3,9 & 3,8 & 0,8 & 2,2 & 1,5 \\
\hline 2-E.A.S. & 2,2 & 3,7 & 0,9 & 5,7 & 0,6 & 7,2 & 2,1 \\
\hline 3-G.N.T. & 4,7 & 5 & 4,6 & 0,8 & 0,9 & 4,5 & 1,1 \\
\hline 4-G.F.M.C. & 2,4 & 2,2 & 2,6 & 5,4 & 0,1 & 2,1 & 2,8 \\
\hline 5-I.R.C. & 1 & 2 & 2,1 & 1,4 & 0,4 & 2,7 & 0,8 \\
\hline 6-J.W.M.O. & 1,5 & 4 & 2,1 & 8,8 & 1,3 & 3,8 & 0,4 \\
\hline 7-L.A.S. & 1,7 & 3,8 & 1,5 & 1,6 & 1,8 & 1 & 1,6 \\
\hline 8-M.A.O. & 1,3 & 5,1 & 2,1 & 0,3 & 0,8 & 6,1 & 0,4 \\
\hline 9-R.S. & 0,7 & 1,2 & 2,6 & 5,3 & 0,2 & 6,7 & 0,7 \\
\hline 10-W.M.S. & 0,7 & 1,9 & 0,7 & 4,7 & 1,2 & 6,1 & 1,5 \\
\hline
\end{tabular}


TABELA A-30

\begin{tabular}{|l|r|r|r|r|r|r|}
\hline \multicolumn{1}{|c|}{ Nome } & PDMI-EIPTM & PDMS-EIPTM & ETPTM-ETC & ETPTM-ETE & ETMI-ETPTM & ETMS-ETPTM \\
\hline 1-B.L.M.E. & 1,1 & 1,3 & 0,5 & 0,4 & 2,4 & 1,6 \\
\hline 2-E.A.S. & 2,9 & 3,2 & 5 & 5,6 & 7,5 & 2,2 \\
\hline 3-G.N.T. & 0,1 & 0,3 & 1,2 & 0,4 & 4,4 & 1 \\
\hline 4-G.F.M.C. & 1,5 & 0,9 & 1,1 & 0,6 & 2,2 & 3 \\
\hline 5-I.R.C. & 2,6 & 3,9 & 1,3 & 0,2 & 3 & 0,8 \\
\hline 6-J.W.M.O. & 1,9 & 0,5 & 1,4 & 0,5 & 4,2 & 0,5 \\
\hline 7-L.A.S. & 5,1 & 3,2 & 2,3 & 2,5 & 1,2 & 1,7 \\
\hline 8-M.A.O. & 4,9 & 3,3 & 1,1 & 0,9 & 5,9 & 0,4 \\
\hline 9-R.S. & 6,8 & 0,7 & 3,3 & 3,2 & 7,1 & 0,8 \\
\hline 10-W.M.S. & 0,4 & 1 & 0,9 & 0,3 & 6,1 & 1,5 \\
\hline
\end{tabular}




\section{FACULDADE DE ODONTOLOGIA DE BAURU}

\section{Comitê de ÉtTICA EM PeSquisa}

Bauru, 30 de março de 2001

Ilmo. Sr

Prof. Dr. Guilherme dos Reis Pereira Janson

FOB USP

Senhor Professor

O projeto de pesquisa denominado "Correlação entre a assimetria facial aparente e assimetria mandibular na Classe II, subdivisão" de autoria da C.D. Angela Rita Pontes de Azevedo e que será desenvolvido sob sua orientação, foi recebido por este Comitê e encaminhado ao relator para avaliaçåo quanto aos seus aspectos éticos.

O parecer do relator, aprovando o projeto, foi aceito pelo Comitê de Ética em Pesquisa desta Faculdade na reunia do dia 29 de março de 2001.

Atenciosamente

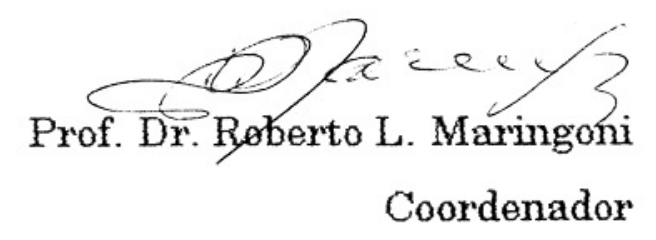

